\title{
FÔRMAS PARA CONCRETO: SUBSÍDIOS PARA A OTIMIZAÇÃO DO PROJETO SEGUNDO A NBR 7190/97
}

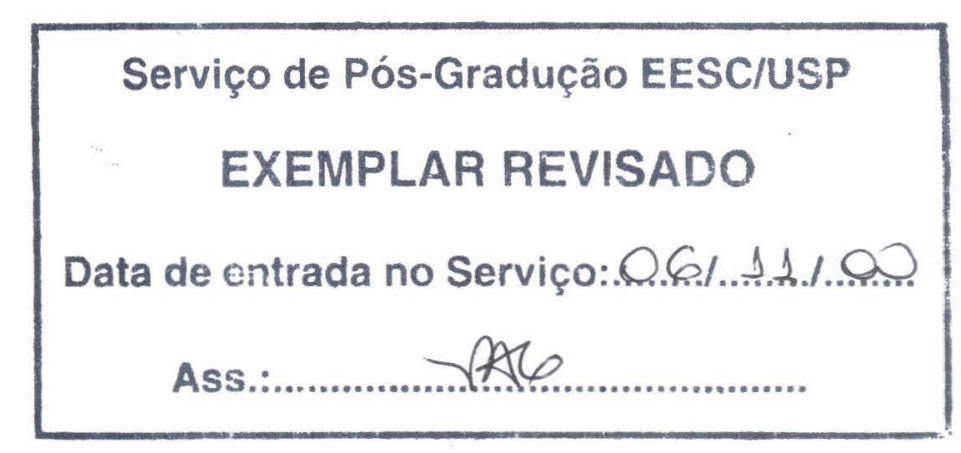

George Magalhães Maranhão



Dissertação apresentada à Escola de

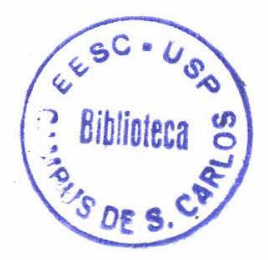
Engenharia de São Carlos da Universidade de São Paulo, como parte dos requisitos para a obtenção do título de Mestre em Engenharia de Estruturas.

ORIENTADOR: Prof. Dr. Francisco Antonio Rocco Lahr

São Carlos

2000 
Hass. IESE. EESC

Cuth.

Tombe T 0248100

Ficha catalográfica preparada pela Seção de Tratamento da Informação do Serviço de Biblioteca - EESC/USP

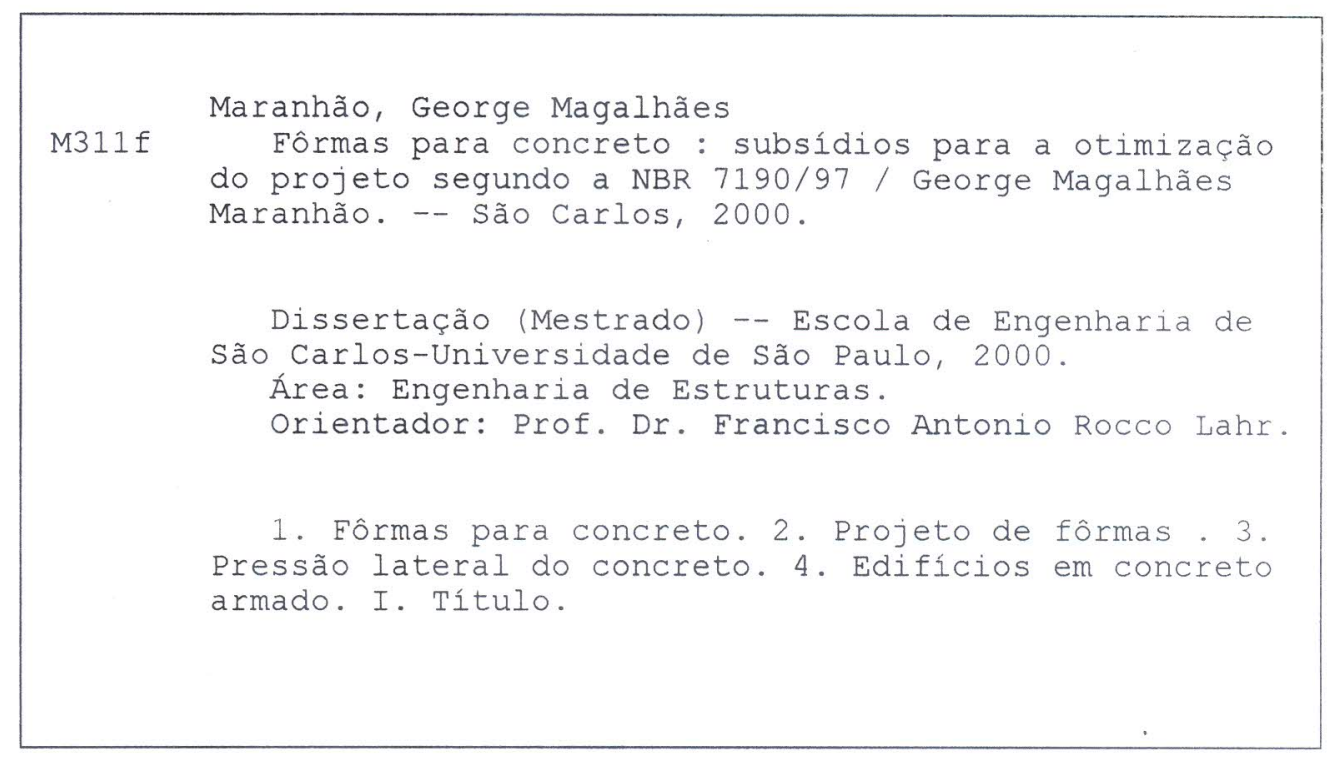




\section{FOLHA DE APROVACÃO}

Candidato: Engenheiro GEORGE MAGALHÃES MARANHÃo

Dissertação defendida e aprovada em 31-07-2000 pela Comissão Julgadora:

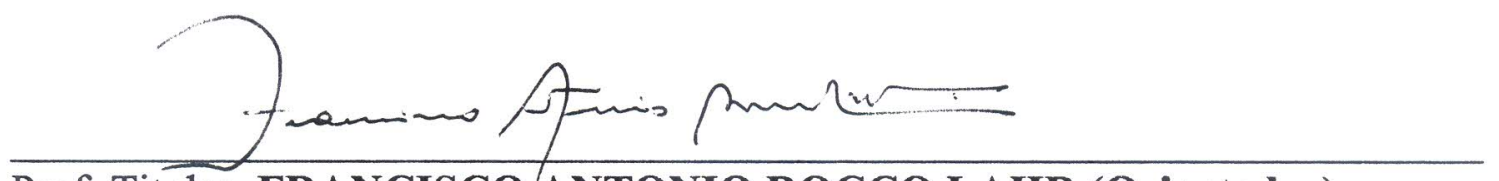

Prof. Titular FRANCISCO ANTONIO ROCCO LAHR (Orientador)

(Escola de Engenharia de São Carlos - Universidade de São Paulo)

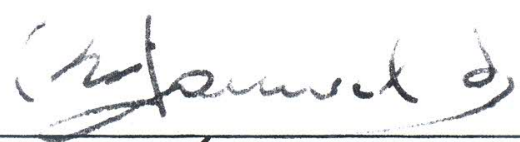

Prof. Doutor JOSÉ SAMUEL GIONGO

(Escola de Engenharia de São Carlos - Universidade de São Paulo)

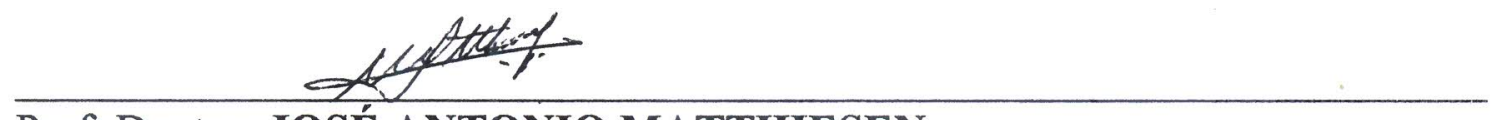

Prof. Doutor JOSÉ ANTONIO MATTHIESEN

(UNESP - Campus de Ilha Solteira)



Coordenadora do Programa de Pós-Graduação em Engenharia de Estruturas

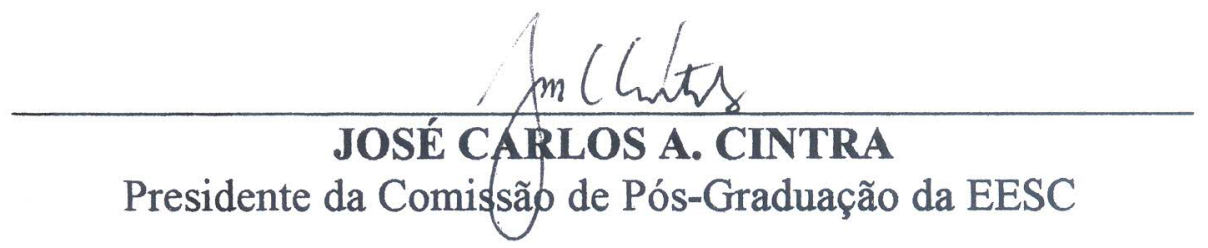


Ao meu pai, José Maria Maranhão, meu primeiro e grande professor. 


\section{AGRADECIMENTOS}

A DEUS, por tudo que sou, que tenho, que posso e que realizo.

Ao mais que orientador, ao amigo professor Francisco Antonio Rocco Lahr, que não poupou atenção, consideração, compreensão, incentivo e apoio, durante o desenvolvimento desse trabalho.

Ao professor Carlito Calil Júnior pela grande colaboração e amizade prestadas ao longo deste período e aos demais professores do Departamento de Estruturas que de alguma forma contribuíram.

Aos funcionários do Laboratório de Madeiras e de Estruturas de Madeira LaMEM, pelo convívio nesse período, que, sem exceção, contribuíram de diversas maneiras para a conclusão desse trabalho.

Aos colegas e amigos da pós-graduação pelos bons momentos vividos e informações trocadas durante o inolvidável cafezinho.

À Fundação de Amparo à Pesquisa do Estado de São Paulo - FAPESP pelo financiamento da pesquisa.

Aos meus irmãos Marcelo, Eduardo e Fernando, pela amizade e incentivo em todos os momentos, meu eterno obrigado.

A todos aqueles que, de alguma maneira, contribuíram para a elaboração desse trabalho. 


\section{SUMÁRIO}

LISTA DE FIgURAS viii

LISTA DE TABELAS xiv

LISTA de ABREVIatURAS E SigLAS xvi

LISTA DE SímBolos xvii

RESUMO

ABSTRACT $\quad \mathbf{x X}$

1. INTRODUÇÃO

1.1 Generalidades 1

1.2 Segurança das fôrmas 3

1.3 Economia nas fôrmas 4

1.4 Patologias na estrutura em função das fôrmas 8

1.5 Sistemas de fôrmas no mercado 9

1.6 Sistema de fôrmas a ser estudado: terminologia e definições 10

$\begin{array}{lll}1.7 & \text { Objetivos e justificativas } & 14\end{array}$

$\begin{array}{lll}1.8 & \text { Organização do trabalho } & 16\end{array}$

2. Chapas de Madeira Compensada 17

$\begin{array}{lll}2.1 & \text { Generalidades } & 17\end{array}$

2.2 Etapas de produção das chapas de madeira compensada 18

$\begin{array}{lll}2.3 & \text { Classificação e especificação das chapas de madeira compensada } & 21\end{array}$

2.4 Propriedades mecânicas e físicas das chapas de madeira compensada 25

$\begin{array}{lll}2.5 & \text { Curvatura das chapas de madeira compensada } & 27\end{array}$

2.6 Orientações para o armazenamento e compra das chapas de madeira $\begin{array}{ll}\text { compensada } & 28\end{array}$

2.7 Cuidados no corte das chapas de madeira compensada 29

2.8 Desmoldantes para chapas de madeira compensada 31 
2.9 Considerações finais 31

3. AÇÕES NAS FÔRMAS 32

3.1 Generalidades 32

3.2 Ações permanentes 33

3.3 Ações variáveis 34

3.3.1 American Concrete Institute - ACl 347R/88 35

3.3.2 Bristish Standards Institution - BS 5975/95 35

3.3.3 Eng $^{\circ}$. João Alberto Venegas REQUENA 35

3.3.4 Associação Brasileira de Cimento Portland - ABCP 36

3.3.5 Comite Euro-International du Beton - CEB 36

3.3.6 Avaliação das propostas sobre ações variáveis 36

3.4 Ações verticais no assoalho de fundo das vigas 37

3.5 Ações devidas às pressões laterais exercidas pelo concreto nas faces das fôrmas $\quad 38$

3.5.1 Comportamento do concreto fresco nas fôrmas 38

3.5.2 Considerações sobre as pressões laterais do concreto 39

3.5.3 Cálculo das pressões laterais nas fôrmas para pilares 42

a) Método do Comite Euro-International du Beton - CEB 42

b) Método do American Concrete Institute - ACI 347R/88 43

c) Método da Deustsches Institut Für Normung - DIN 18218/80 44

d) Método de N. J. GARDNER 46

e) Método da Teoria de Empuxo de Materiais Sólidos e Granulosos sobre $\begin{array}{ll}\text { as paredes dos silos } & 46\end{array}$

3.5.4 Cálculo das pressões laterais nas fôrmas para vigas 47

3.6 Ações horizontais 48

$\begin{array}{lll}3.7 & \text { Outras ações } & 49\end{array}$

3.8 Combinações das ações $\quad 52$

3.8.1 Estados limites últimos 52

3.8.2 Estados limites de utilização 53

3.9 Considerações finais 53

4. EXPERIMENTAÇÃO

4.1 Generalidades 54

4.2 Realização do ensaio $\quad 55$

$\begin{array}{lll}4.3 & \text { Análise numérica } & 58\end{array}$

$\begin{array}{lll}4.4 & \text { Resultados da investigação experimental } & 61\end{array}$ 
4.5 Resultados da análise numérica 62

4.6 Análise numérica x Investigação experimental 63

4.7 Formulação para o cálculo da pressão lateral do concreto 63

$\begin{array}{lll}4.8 & \text { Considerações finais } & 67\end{array}$

5. Dimensionamento das FôRmas 69

$\begin{array}{lll}5.1 & \text { Generalidades } & 69\end{array}$

5.2 Conceitos da NBR 7190 (1997) 70

$\begin{array}{ll}\text { 5.2.1 Cálculo das resistências características } & 70\end{array}$

5.2.2 Coeficientes de ponderação da resistência para estados limites últimos e de utilização

$\begin{array}{ll}\text { 5.2.3 Valores de cálculo das resistências } & 71\end{array}$

$\begin{array}{lll}5.3 & \text { Flechas máximas } & 76\end{array}$

$\begin{array}{lll}5.4 & \text { Flexão simples reta } & 77\end{array}$

$\begin{array}{lll}5.5 & \text { Cisalhamento } & 78\end{array}$

$\begin{array}{lll}5.6 & \text { Flexão composta } & 79\end{array}$

5.6.1 Estabilidade 80

a) Peças curtas $\quad 80$

b) Peças medianamente esbeltas $\quad 81$

C) Peças esbeltas 82

5.6.2 Peças compostas 83

$\begin{array}{lll}5.7 & \text { Ligações } & 85\end{array}$

5.8 Dimensionamento dos subsistemas que compõem o sistema de fôrmas $\quad 88$

5.8.1 Subsistema de fôrmas para lajes $\quad 89$

$\begin{array}{ll}\text { 5.8.2 Subsistema de fôrmas para vigas } & 92\end{array}$

$\begin{array}{ll}\text { 5.8.3 Subsistema de fôrmas para pilares } & 94\end{array}$

5.9 Exemplo comentado de dimensionamento dos subsistemas que compõem o sistema de fôrmas 95

5.9.1 Subsistema de fôrmas para lajes 96

$\begin{array}{ll}\text { 5.9.2 Subsistema de fôrmas para vigas } & 109\end{array}$

$\begin{array}{ll}\text { 5.9.3 Subsistema de fôrmas para pilares } & 123\end{array}$

$\begin{array}{ll}5.10 \text { Considerações finais } & 127\end{array}$

6. DisPosições CONSTRUTIVAS 128

$\begin{array}{llr}6.1 & \text { Generalidades } & 128\end{array}$

$\begin{array}{ll}6.2 & \text { Fôrmas para lajes } \\ \end{array}$ 
$\begin{array}{llr}6.3 & \text { Fôrmas para vigas } & 139\end{array}$

$\begin{array}{lll}6.4 & \text { Fôrmas para pilares } & 146\end{array}$

6.5 Locação das fôrmas através de sistemas de eixos 151

6.6 Elementos de pressão ou "moscas" 153

6.7 Método de Grundy e Kabaila para o escoramento e reescoramento das estruturas 154

$\begin{array}{lll}\text { 6.8 Cura e prazos de retirada das fôrmas } & 161\end{array}$

$\begin{array}{ll}6.9 & \text { Operações de montagem e desfôrma } \\ 6.165\end{array}$

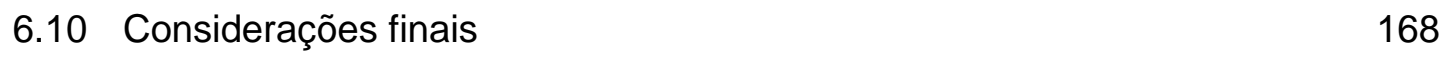

$\begin{array}{ll}\text { 7. Projeto de FôRMAS } & 169\end{array}$

$\begin{array}{lll}7.1 & \text { Generalidades } & 169\end{array}$

7.2 Simbologia e terminologia para o projeto de fôrmas 170

$\begin{array}{ll}7.3 & \text { Composição de um projeto de fôrmas } \\ & 172\end{array}$

$\begin{array}{ll}\text { a) Relatório explicativo } & 173\end{array}$

b) Desenhos dos Painéis de Pilares 173

$\begin{array}{ll}\text { c) Desenhos dos Painéis de Vigas } & 173\end{array}$

d) Desenhos dos Garfos $\quad 174$

e) Planta de Paginação dos Painéis de Lajes 174

f) Planta de Locação de Longarinas e Escoras 174

g) Planta de Montagem dos Painéis de Vigas 174

h) Planta de Locação de Garfos e Pontaletes $\quad 175$

i) Planta de Locação de Pontaletes e Faixas para Reescoramento de $\begin{array}{ll}\text { Lajes } & 175\end{array}$

j) Planta de Locação de Pontaletes e Faixas para Reescoramento de $\begin{array}{ll}\text { Vigas } & 175\end{array}$

k) Plano de Corte $\quad 175$

$\begin{array}{lll}7.4 & \text { Definição do preço para o projeto de fôrmas } & 176\end{array}$

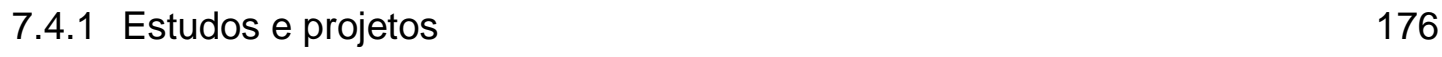

$\begin{array}{ll}\text { a) Estudos preliminares } & 176\end{array}$

$\begin{array}{ll}\text { b) Anteprojeto } & 176\end{array}$

c) Projeto básico 177

$\begin{array}{ll}\text { d) Projeto executivo } & 177\end{array}$

$\begin{array}{ll}\text { e) Projeto de fabricação } & 177\end{array}$

f) Projeto de montagem 177

$\begin{array}{ll}\text { 7.4.2 Modalidades de fixação de preços } & 177\end{array}$ 
7.4.3 Projetos de fôrmas e cimbramentos

7.4.4 Adicionais específicos para projetos de fôrmas e cimbramentos

7.4.5 Repetições de projetos

7.5 Considerações finais

8. Conclusão 182

BIBLIOGRAFIA 184

ANEXO

A.1

A.1 Fundamentos teóricos para construção de ábacos para o dimensionamento de chapas de madeira compensada

A.2 Algoritmos para o dimensionamento dos subsistema de fôrmas 


\section{LISTA DE FIGURAS}

FIGURA 1.1 - Custo unitário relativo, ao longo do tempo, para diferentes indústrias

FIGURA 1.2 - Participações no custo de uma estrutura de concreto armado

FIGURA 1.3 - Exemplo de redução na seção de um pilar

FIGURA 1.4 - Corte na seção transversal da viga juntamente com a laje: (a) do térreo que servirá de estacionamento e (b) do pavimento tipo do edifício

FIGURA 1.5 - Painel lateral da fôrma de um pilar utilizado (a) no térreo com o complemento na parte central e (b) no pavimento tipo, sem o complemento em chapa de madeira compensada

FIGURA 1.6 - Subsistema de Fôrmas para as lajes 11

FIGURA 1.7 - Subsistema de Fôrmas para as vigas 12

FIGURA 1.8 - Subsistema de Fôrmas para os pilares 13

FIGURA 2.1 - Obtenção das lâminas por corte rotatório 19

FIGURA 2.2 - Etapas de produção das chapas de madeira compensada 21

FIGURA 2.3 - Variação dos parâmetros característicos das lâminas de madeira no plano longitudinal-tangencial

FIGURA 2.4 - Composição das lâminas e variação dos parâmetros elásticos dos compostos obtidos

FIGURA 2.5 - Tipos de serras quanto ao tamanho dos dentes

FIGURA 3.1 - Fôrma de um pilar inclinado com seus possíveis modos de carregamento

FIGURA 3.2 - Desenvolvimento da envoltória da pressão lateral do concreto 
FIGURA 3.3 - Pressão do concreto nas faces laterais da fôrma: (a) corte e (b) diagrama de pressões

FIGURA 3.4 - Diagrama de pressões nas fôrmas para vigas

FIGURA 3.5 - Carregamento $\left(F_{h}\right)$ para cálculo do contraventamento do sistema de fôrmas

FIGURA 3.6 - Carregamento $\left(F_{h}\right)$ para cálculo do contraventamento do pilar

FIGURA 3.7 - Concentração de um grande volume de concreto fresco num determinado vão, podendo ocasionar o levantamento da fôrma

FIGURA 3.8 - Possíveis tipos de anomalias nos sistemas de fôrmas

FIGURA 4.1 - Corte longitudinal do pilar com o tensor preparado para o ensaio

FIGURA 4.2 - Aferição dos tensores: (a) Tensores e (b) Aferição através do ensaio de tração

FIGURA 4.3 - Pilar Ensaiado: (a) Planta baixa e (b) Vista lateral com a posição dos tensores

FIGURA 4.4 - Equipamentos de medição: ponte para medição de deformação e caixa seletora

FIGURA 4.5 - Seção transversal da fôrma para o pilar instrumentado

FIGURA 4.6 - Montagem e realização do ensaio: (a) pilar instrumentado; (b) detalhe do tensor no pilar; (c) equipamentos de medição e (d) concretagem

FIGURA 4.7 - Procedimentos de cálculo das forças dos tensores: (a) simplificado; (b) utilizado no presente trabalho e (c) mais exato

FIGURA 4.8 - Modelo estático adotado no cálculo das forças nos tensores

FIGURA 4.9 - Gráfico das pressões nos vários estágios de tempo

FIGURA 4.10 - Gráfico comparativo dos valores das pressões teóricas e experimental

FIGURA 4.11 - Gráfico representando o critério de Mohr-Coulomb

FIGURA 4.12 - Gráfico com a linearização da curva experimental

FIGURA 5.1 - (a) Flecha limite na viga como elemento estrutural e (b) flecha limite na fôrma para a viga (aumentado em 30x) 
FIGURA 5.2 - Vista frontal, lateral e seção transversal de um garfo, usado para o escoramento das vigas

FIGURA 5.3 - Seção transversal do garfo e do elemento que compõe o mesmo

FIGURA 5.4 - Esquema estático da chapa de madeira compensada, dois ou mais apoios

FIGURA 5.5 - (a) Seção transversal de uma viga com a fôrma e (b) encontro da fôrma da laje com a face lateral da fôrma da viga

FIGURA 5.6 - Ações a que estão submetidas as faces laterais das fôrmas de vigas

FIGURA 5.7 - Planta baixa e cortes da estrutura a ser dimensionada as fôrmas (medidas em cm)

FIGURA 5.8 - Arranjo das chapas de madeira compensada na laje (medidas em $\mathrm{cm}$ )

FIGURA 5.9 - Disposição das transversinas nas chapas de $n^{\circ s} .01,03$, 04, 06, 07 e 09

FIGURA 5.10 - Esquema estático das chapas de $n^{\text {os }} .01,03,04,06,07$ e 09

FIGURA 5.11 - (a) Disposição das transversinas e (b) esquema estático das chapas de $n^{0 s}$. 02, 05 e 08

FIGURA 5.12 - Arranjo das transversinas que dão apoio às chapas de madeira compensada (medidas em $\mathrm{cm}$ )

FIGURA 5.13 - Esquema estático para as transversinas

FIGURA 5.14 - Arranjo das longarinas que dão apoio às transversinas (medidas em cm)

FIGURA 5.15 - Modelos estático da (a) situação real, (b) com a primeira simplificação e (c) com a segunda simplificação

FIGURA 5.16 - Arranjo das escoras que dão suporte às longarinas (medidas em cm)

FIGURA 5.17 - Escora que dá suporte à longarina 107

FIGURA 5.18 - Painel de fundo da fôrma da viga 110

FIGURA 5.19 - Homogeneização do painel de fundo da fôrma da viga 
FIGURA 5.20 - (a) Seção transversal da viga V01 $(12 \mathrm{~cm}$ x $60 \mathrm{~cm})$, (b) esquema estático (painel lateral externo) com carregamento triangular e (c) simplificação com carregamento uniformemente distribuído

FIGURA 5.21 - (a) Simplificação com carregamento uniformemente distribuído, (b) esquema estático (painel lateral interno) com carregamento trapezoidal e (c) seção transversal da viga V01 $(12 \mathrm{~cm} \times 60 \mathrm{~cm})$

FIGURA 5.22 - (a) Vista fontal e (b) lateral do garfo usado para o escoramento das vigas

FIGURA 5.23 - Carga suportada pelas chapas laterais do garfo

FIGURA 5.24 - Detalhe das forças ativa e reativa na ligação das chapas laterais no garfo

FIGURA 5.25 - (a) Seção transversal da fôrma do pilar e (b) esquema estático da pressão lateral do concreto

FIGURA 5.26 - Espaçamento vertical dos tensores ao londo pilar P01

FIGURA 6.1 - (a) Longarina de madeira e (b) detalhe da emenda entre longarinas (medidas em cm)

FIGURA 6.2 - (a) Transversina em madeira e (b) longarina mista (madeira e aço)

FIGURA 6.3 - Detalhe dos garfos das vigas com (a) as transversinas e (b) longarinas apoiadas em guias

FIGURA 6.4 - Detalhe dos garfos das vigas com (a) as transversinas e (b) as longarinas sem apoio

FIGURA 6.5 - Planta baixa de uma estrutura com as transversinas e longarinas não apoiadas, com desconto de $20 \mathrm{~cm}$ por extremidade (medidas em $\mathrm{cm}$ )

FIGURA 6.6 - Planta baixa de uma estrutura com as transversinas e longarinas apoiadas, com desconto de $7 \mathrm{~cm}$ por extremidade (medidas em $\mathrm{cm}$ )

FIGURA 6.7 - Detalhe da chapa metálica na faixa de reescoramento para auxílio da desfôrma

FIGURA 6.8 - Esquema de uma escora de madeira com transversina e longarina 
FIGURA 6.9 - Esquema de uma escora de madeira apenas com a longarina

FIGURA 6.10 - Esquema de eixos para o nivelamento das escoras de acordo com a contra-flecha estabelecida no projeto de estruturas

FIGURA 6.11 - Pontalete metálico com tubos deslizantes através de um sistema telescopável

FIGURA 6.12 - Cabeçal de apoio (a) simples e (b) duplo

FIGURA 6.13 - Suporte para pontalete metálico

FIGURA 6.14 - Emenda de transversinas mistas através do cabeçal duplo

FIGURA 6.15 - Seção transversal de uma viga de perímetro com as dimensões dos painéis

FIGURA 6.16 - Emenda entre dois painéis de viga através de chapuz

FIGURA 6.17 - Viga direta de perímetro

FIGURA 6.18 - Viga invertida de perímetro

FIGURA 6.19 - Viga semi-invertida de perímetro

FIGURA 6.20 - Corte do garfo para utilização nos pavimentos tipo

FIGURA 6.21 - Tensores para vigas de grande altura

FIGURA 6.22 - Cruzeta, para suporte de vigas

FIGURA 6.23 - Gastalho, para travamento das faces laterais das fôrmas

FIGURA 6.24 - Fôrma de viga com reforço através de gravatas a meia altura

FIGURA 6.25 - Escoramento de vigas e laje utilizando-se torres e vigas metálicas

FIGURA 6.26 - Seção transversal, vista frontal e lateral da fôrma de um pilar com sarrafeamento horizontal

FIGURA 6.27 - Seção transversal, vista frontal e lateral da fôrma de um pilar com sarrafeamento vertical

FIGURA 6.28 - Seção transversal, vista frontal e lateral da fôrma de um pilar sem sarrafeamento, travado através de guias de amarração

FIGURA 6.29 - Seção transversal, vista frontal e lateral da fôrma de um pilar sem sarrafeamento, travado através de gravatas de amarração 
FIGURA 6.30 - Gastalho para a locação dos pilares

FIGURA 6.31 - Gastalho "maluco" para a fixação do contraventamento e prumagem dos pilares

FIGURA 6.32 - Detalhe do prolongamento da chapa compensada nas fôrmas para pilares

FIGURA 6.33 - Possíveis deslocamentos do eixo principal em relação ao eixo vertical

FIGURA 6.34 - Projeto de medidas para fixação dos gastalhos

FIGURA 6.35 - Detalhe do elemento de pressão (ou "mosca") no encontro de duas vigas

FIGURA 6.36 - Fatores de carga (k) para pavimentos e pontaletes $(2+2)$

FIGURA 6.37 - Fatores de cargas máximos para cada pavimento 158

FIGURA 6.38 - Diagrama de fatores de carga para o quarto pavimento 158

FIGURA 6.39 - História de carregamentos construtivos para o quarto pavimento

FIGURA 6.40 - Desenvolvimento da resistência à compressão do concreto para diferentes tempos de cura úmida

FIGURA 7.1 - Convenção para nomenclatura de painéis de fôrmas

FIGURA 7.2 - Exemplo de nomenclatura para uma estrutura qualquer 


\section{LISTA DE TABELAS}

TABELA 1.1 - Custos da estrutura de concreto de um edifício hipotético (em dólares)

TABELA 1.2 - Sistema de Fôrmas a ser estudado

TABELA 2.1 - Tolerâncias segundo as características das chapas de madeira compensada

TABELA 2.2 - Teor de umidade de equilíbrio à temperatura de $20^{\circ} \mathrm{C}$

TABELA 2.3 - Raios de curvatura mínimo de acordo com a espessura da chapa

TABELA 2.4 - Sugestões para tipos de serras

TABELA 3.1 - Pesos específicos dos materiais comumente utilizados nas fôrmas

TABELA 3.2 - Fatores que influenciam na pressão lateral do concreto

TABELA 3.3 - Valores do fator $\mathrm{K}$

TABELA 3.4 - Valores do abatimento do concreto de acordo com sua consistência

TABELA 4.1 - Valores das pressões no término da concretagem

TABELA 4.2 - Valores das pressões máximas, segundo os métodos estudados

TABELA 4.3 - Resultado dos Ensaios

TABELA 5.1 - Valores de $\mathrm{k}_{\text {mod, } 1}$

TABELA 5.2 - Classes de Carregamento 72

TABELA 5.3 - Valores de $\mathrm{k}_{\text {mod,2 }} \quad 73$

TABELA 5.4 - Classes de Umidade 73

TABELA 5.5 - Tensões convencionais de ruptura na flexão, resistência ao cisalhamento e módulos de elasticidade nas direções paralelas e perpendicular à grã das lâminas externas 
TABELA 5.6 - Valores característicos das resistências e médios dos módulos de elasticidade

TABELA 5.7 - Valores de cálculo das resistências e médios dos módulos de elasticidade

TABELA 5.8 - Coeficiente de fluência $\phi$

TABELA 5.9 - Algumas dimensões de pregos 86

$\begin{array}{ll}\text { TABELA } 5.10 \text { - Coeficientes } \mathrm{K}_{\mathrm{M}}, \mathrm{K}_{\mathrm{V}} \text { e } \mathrm{K}_{\mathrm{f}} & 90\end{array}$

TABELA 5.11 - Especificações da chapa de madeira compensada 97

TABELA 5.12 - Especificações da Madeira E. Grandis 97

TABELA 5.13 - Momento máximo, cortante máximo e flechas para os três esquemas estático

TABELA 5.14 - Vãos dimensionados para os painéis da fôrma da viga V01, de acordo com alguns esquemas estático

TABELA 6.1 - Comprimentos dos elementos que formam o garfo, de acordo com a viga a ser escorada

TABELA 6.2 - Valores máximos e convergente dos fatores de carga para os pavimentos

TABELA 6.3 - Relações $\mathrm{f}_{\mathrm{c}}(\mathrm{t}) / \mathrm{f}_{\mathrm{c} 28}$, para $21^{\circ} \mathrm{C}<\mathrm{T}<30^{\circ} \mathrm{C}$

TABELA 6.4 - Prazo de desfôrma segundo a NBR 7678 (1983) 163

TABELA 6.5 - Prazo de desfôrma das faces laterais

TABELA 6.6 - Prazo de desfôrma nas faces de fundo de lajes, vigas e escoramento

TABELA 7.1 - Simbologia para o desenho no projeto de fôrmas

TABELA 7.2 - Coeficiente $k$

TABELA 7.3 - Adicional específico de acordo com a quantidade de pares de eixos

TABELA 7.4 - Percentual aplicado ao preço do projeto para repetições 


\section{Lista de Abreviaturas e Siglas}

$\begin{array}{ll}\text { ABNT } & \text { - Associação Brasileira de Normas Técnicas } \\ \text { ABCP } & - \text { Associação Brasileira de Cimento Portland } \\ \mathrm{ACl} & - \text { American Concrete Institute } \\ \mathrm{BS} & - \text { Bristish Standards Institution } \\ \mathrm{CEB} & - \text { Comite Euro-International du Beton } \\ \text { EESC } & - \text { Escola de Engenharia de São Carlos } \\ \text { HPMA } & - \text { Hardwood Plywood Manufacturers Association } \\ \text { LaMEM } & - \text { Laboratório de Madeiras e Estruturas de Madeira } \\ \text { NB } & - \text { Norma Brasileira } \\ \text { NBR } & - \text { Norma Brasileira Registrada } \\ \text { USP } & - \text { Universidade de São Paulo }\end{array}$




\section{LISTA DE Símbolos}

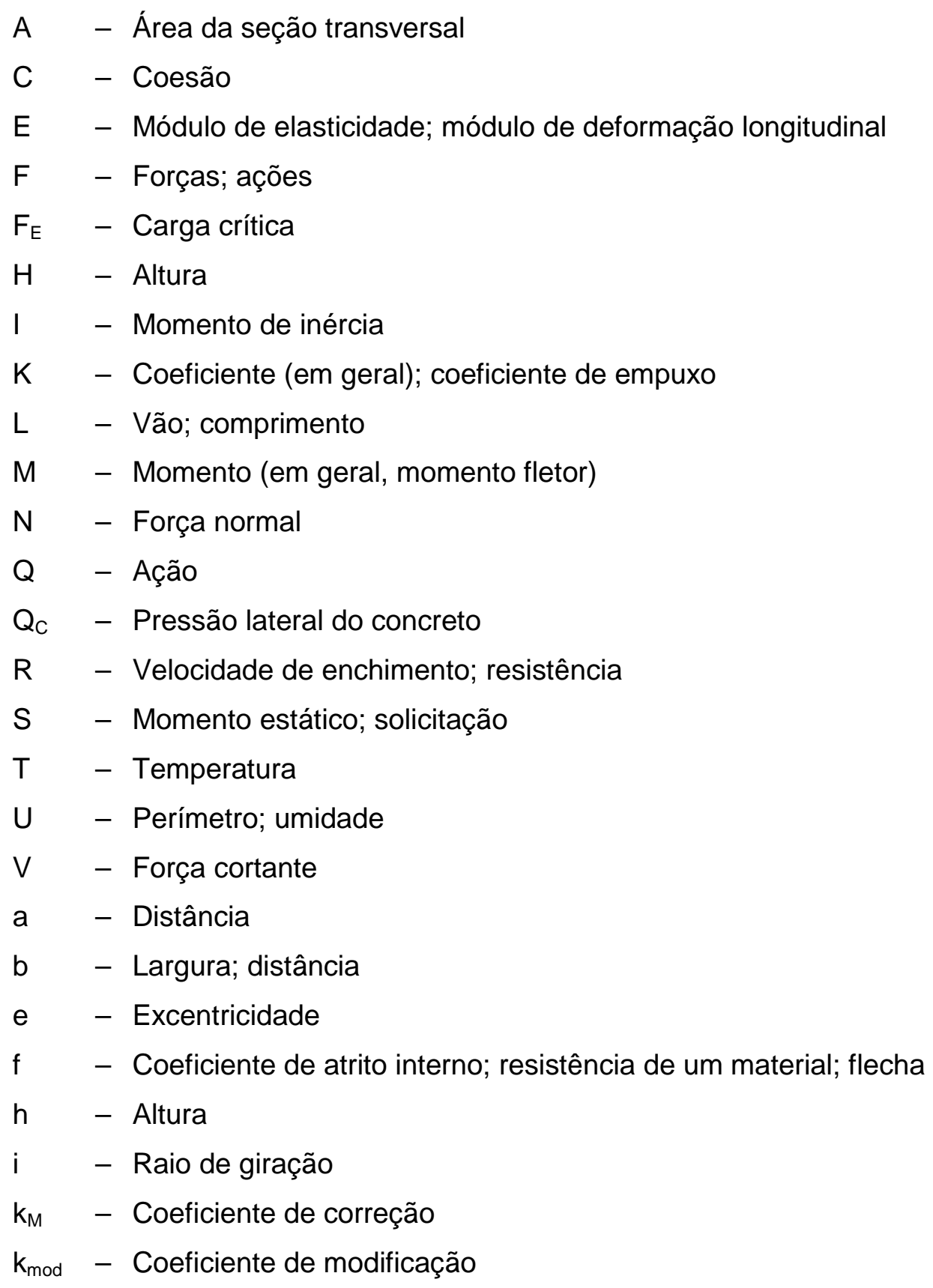




$$
\begin{array}{ll}
\mathrm{t} & - \text { Largura } \\
\mathrm{x} & - \text { Coordenada } \\
\mathrm{y} & - \text { Distância; coordenada } \\
\alpha & - \text { Coeficiente } \\
\beta & - \text { Coeficiente } \\
\gamma & - \text { Peso específico; coeficiente de segurança } \\
\lambda & - \text { Índice de esbeltez } \\
\rho & - \text { Massa específica (densidade) } \\
\sigma & - \text { Tensão normal } \\
\tau & - \text { Tensão cisalhante } \\
\phi & - \text { Coeficiente de fluência; ângulo; diâmetro } \\
\varphi & - \text { Ângulo } \\
\psi & - \text { Coeficiente }
\end{array}
$$




\section{RESUMO}

MARANHÃO, G. M. (2000). Fôrmas para Concreto: subsídios para a otimização do projeto segundo a NBR 7190/97. São Carlos, 2000. 188p. Dissertação (Mestrado) Escola de Engenharia de São Carlos, Universidade de São Paulo.

O elevado nível de conhecimento na fabricação de novos materiais e nas etapas da elaboração do projeto de estruturas não se repete quando são avaliadas as técnicas de execução de edificações. Por outro lado, a economia globalizada tornou indispensável a racionalização na construção civil e, no que refere ao item fôrmas, esta só é possível com o ação de um profissional especializado, ainda raro no mercado de trabalho da engenharia brasileira. Neste contexto, este trabalho apresenta procedimentos para se alcançar a redução no custo final da construção quando bem delineados os projetos arquitetônico e estrutural, com ênfase em aspectos construtivos. São também mostrados os benefícios da correta definição do "Projeto de Fôrmas", necessidade imperiosa no conjunto de elementos gráficos que constituem o projeto de um edifício. Os princípios e as técnicas para a análise e o projeto das fôrmas para estruturas de concreto são apresentadas de acordo com a nova versão da norma brasileira (Projeto de Estruturas de Madeira - 1997), fundamentada no método dos estados limites. Os ensaios experimentais realizados nas faces laterais das fôrmas dos pilares definem uma proposta de formulação para o cálculo da pressão lateral que o concreto exerce nessas faces (segundo a teoria de Mohr-Coulomb), necessário para o dimensionamento de peças integrantes das fôrmas. Por fim, são apresentadas as premissas para a elaboração projetual de um sistema de fôrmas para edifícios de múltiplos andares.

Palavras-chave: Fôrmas para concreto; projeto de fôrmas; pressão lateral do concreto; edifícios em concreto armado. 


\section{ABSTRACT}

MARANHÃO, G. M. (2000). Formwork for Concrete: subsidies to optimizing the design according NBR 7190/97 (Brazilian Code - Design of Timber Structures). São Carlos, 2000. 188p. Dissertação (Mestrado) - Escola de Engenharia de São Carlos, Universidade de São Paulo.

The high level of knowledge in the production of new materials and in the steps of structural design is not present on the construction techniques of multistorey buildings. On the other hand, to global economy it becomes indispensable to introduce rationalization concepts in civil construction, especially in formwork. This introduction is only possible with the action of an expert, who is still rare in Brazilian Civil Engineering. In this context, this work aims the presentation of procedures to reach a reduction on the final cost of multi-storey buildings, when architectural and structural design are well outlined, with emphasis to constructive details. Furthermore, the benefits of a proper definition of the "Formwork Design" are presented, due to its fundamental role in the graphical elements of a project. The principles of formwork design are presented according to new Brazilian Code (Design of Timber Structures -1997), based on limit states method. Tests on the lateral faces of column formwork originated a proposal to estimate lateral pressures applied by the concrete (according to Mohr-Coulomb Theory), which is necessary to detail formwork elements. Finally, the premises to design the formwork of a multistorey building are presented.

Keywords: formwork for concrete; formwork design; concrete pressure; reinforced concrete buildings. 


\section{INTRODUÇÃO}

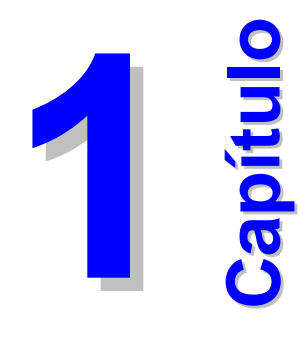

\subsection{Generalidades}

No Brasil, desde o início do século, o concreto armado vem sendo empregado nas construções de edifícios. O item fôrmas não era relevante na composição de custos de uma obra, pois tanto o material quanto a mão de obra representavam uma pequena porcentagem no custo das fôrmas. Tal não acontece hoje, onde se tem o percentual de $60 \%$, em média, das horas gastas para moldar a estrutura, dedicado às fôrmas; outros $25 \%$ para a armação e os $15 \%$ restantes para a concretagem.

Conhecidas dos construtores desde tempos imemoriais, as fôrmas para estruturas de concreto vêm sofrendo paulatina renovação, com novas tecnologias e materiais desenvolvidos em países em que a construção civil se encontra mais industrializada. Em essência, são destinadas a sustentar o concreto fresco até que o mesmo atinja condições de auto suporte. Sua importância não se limita somente a esta condição, pois também são responsáveis pela garantia de obtenção das 
dimensões desejadas da estrutura de concreto, bem como pela textura do acabamento final das superfícies.

A construção civil brasileira emprega largamente o concreto armado, havendo uma estreita relação entre os volumes ou áreas construídas e o consumo de cimento. Quanto a este material, seu emprego em estruturas de concreto armado prepondera sobre todos os demais (tais como: revestimentos, argamassas, etc.). Referir-se à estrutura de concreto armado significa indiretamente referir-se a "Fôrmas para Concreto", pois sem estas, aquelas não podem ser construídas.

No preparo das fôrmas é generalizado o emprego de madeira que foi e continua sendo a matéria prima principal utilizada na fabricação dos moldes para concreto armado, embora alguns tipos de fôrmas empreguem outros tipos de materiais, em especial o aço (fôrmas metálicas). Dentro dessa colocação, a grande transformação deu-se com a introdução das chapas de madeira compensada, que viriam substituir gradativamente a tábua de Pinho do Paraná (Araucaria angustifolia), isto a partir dos anos 40, início dos anos 50 .

É preciso desmitificar uma prática comum na maior parte das construtoras, onde a tarefa do planejamento e projeto de fôrmas fica a cargo do engenheiro da obra que, dada a intensidade de suas atribuições, que chegam até responsabilidades comerciais, acaba delegando ao mestre e encarregados de carpintaria esta execução. Evidentemente, por este caminho as fôrmas acabam sendo executadas sem o necessário estudo racional de economia, sem verificação de resistência ou deformabilidade ou, no melhor dos casos, sem análise da facilidade de desforma para futuro reaproveitamento. Isso contribui para o caos da indústria da construção civil, sendo que vários trabalhos têm mostrado a situação precária que vive a construção. PAULSON (1995) mostra, através do gráfico da FIGURA 1.1, a variação percentual dos custos unitários dos produtos da construção comparada com algumas outras indústrias. 


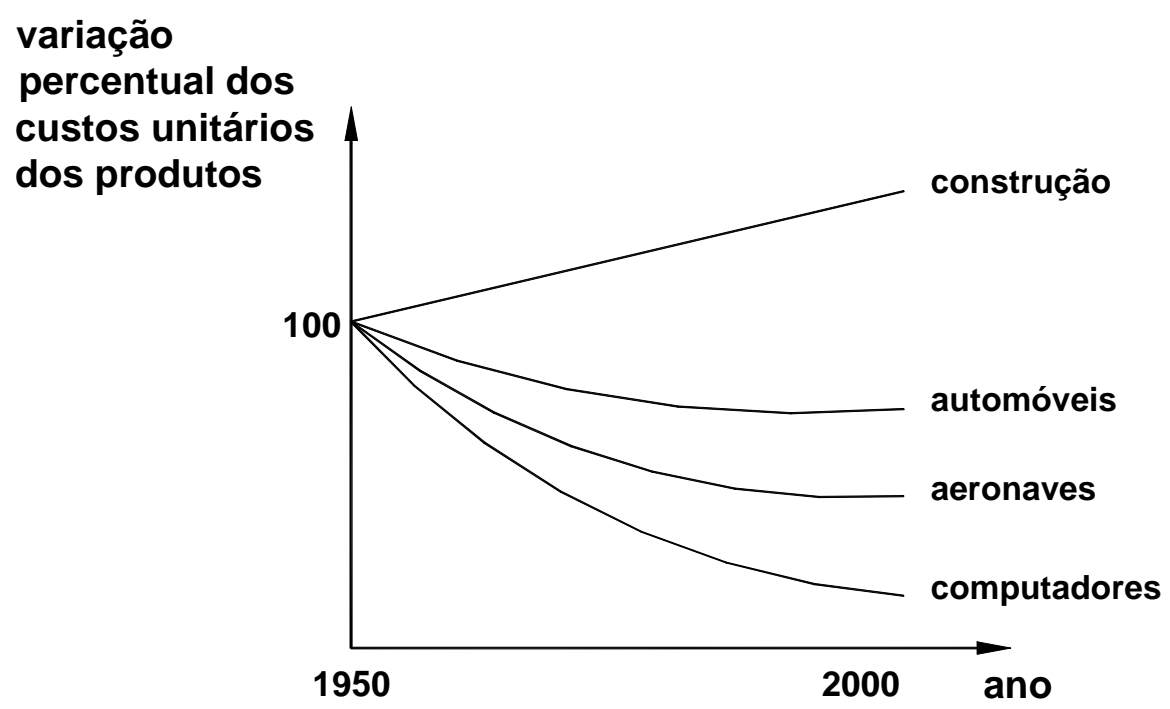

FIGURA 1.1 - Custo unitário relativo, ao longo do tempo, para diferentes indústrias [Fonte: PAULSON (1995)]

\subsection{Segurança das fôrmas}

As fôrmas de concreto devem apresentar resistência suficiente para suportar esforços provenientes de seu peso próprio, do peso e empuxo lateral do concreto, do adensamento, do trânsito de pessoas e equipamentos; rigidez suficiente para manter as dimensões e formas previstas no projeto estrutural para os elementos de concreto. Sua estabilidade deve ser garantida utilizando-se suportes e contraventamentos.

Em recente pesquisa, HADIPRIONO AND WANG (1986), cobrindo 85 casos de colapso em diversos tipos de estruturas, ocorridos no período 1963-1986, constataram que 49\% aconteceram durante a fase de concretagem. Adicionalmente, $48 \%$ dos 46 casos de colapsos observados em edifícios ocorreram em sistemas de escoramento tipo vertical, formados por escoras verticais de madeira, muito adotados na construção civil brasileira.

Apesar dos princípios, conceitos e métodos estarem bem difundidos, proporcionando o básico para a análise e o projeto das fôrmas, é a experiência e a responsabilidade de cada projetista que vão assegurar que as fôrmas são adequadamente projetadas. Isto requer uma análise cautelosa das condições de trabalho em cada obra, a determinação das ações que serão aplicadas nas fôrmas, 
e a seleção e escolha adequada dos materiais que comporão o sistema de fôrmas, garantindo a resistência adequada para sustentar todo o carregamento.

É responsabilidade dos trabalhadores da obra a fabricação e montagem das fôrmas, de acordo com o projeto. Uma cautelosa verificação do projeto e a inspeção do trabalho durante a construção, por parte da equipe técnica da obra, são necessárias para assegurar segurança e confiança ao sistema de fôrmas.

Por maiores que sejam os cuidados tomados com o projeto estrutural, com o controle tecnológico do concreto, com a preparação das armaduras, pode haver prejuízos se pouca importância for dada ao sistema de fôrmas. Segurança é responsabilidade de todos.

\subsection{Economia nas fôrmas}

No plano econômico, o custo das fôrmas participa com cerca de $40 \%$ a $60 \%$ do custo total da estrutura de concreto armado. Por outro lado, esta representa cerca de $20 \%$ do custo de uma edificação. Portanto, em números aproximados ao se estudar este assunto, se está trabalhando com um item que responde entre $8 \%$ e $12 \%$ do custo de uma edificação. Apenas estes números já justificam a importância do tema e dão uma idéia de sua magnitude. Deve ser considerada a possibilidade do reaproveitamento das fôrmas, que passa a ser o único componente de custo variável, o que não acontece com a massa de concreto e a armação, lançadas para ficarem fazendo parte definitiva da estrutura. Surge, assim, o conceito de "Amortização dos Custos das Fôrmas" pelo número de reutilizações alcançadas. O gráfico da FIGURA 1.2 mostra a participação das fôrmas no custo total de uma estrutura. Esses dados são referentes ao mês de fevereiro/2000. Os preços foram pesquisados em São Paulo-SP, incluem os materiais, mão-de-obra, equipamentos, leis sociais $(124,46 \%)$ e $\mathrm{BDI}(15 \%)$.



FIGURA 1.2 - Participações no custo de uma estrutura de concreto armado [Fonte: REVISTA CONSTRUÇÃO (2000)] 
A economia deve ser considerada inicialmente quando se estiver projetando a estrutura e continuar com o planejamento do sistema de fôrmas para a estrutura de concreto. Economia envolve muitos fatores, incluindo o custo dos materiais; o custo da mão-de-obra na fabricação, montagem e desmontagem das fôrmas, e o custo dos equipamentos requeridos para fabricação das fôrmas. Economia também inclui o número de reutilizações das fôrmas, a possibilidade de utilização das fôrmas em outras partes, e o tipo de superfície final do concreto após as fôrmas serem removidas. O alto custo inicial dos materiais, como por exemplo as fôrmas metálicas, podem ser diluídos em razão do grande número de utilizações por elas obtido.

A TABELA 1.1 ilustra o impacto do projeto estrutural no custo total para um edifício hipotético, em que se priorizou, primeiramente, a economia nos materiais permanentes (concreto e aço), e em seguida, os processos construtivos. As informações contidas na TABELA 1.1 foram extraídas da publicação CONCRETE BUILDINGS, NEW FORMWORK PERSPECTIVES (1985).

TABELA 1.1 - Custos da estrutura de concreto de um edifício hipotético (em dólares)

\begin{tabular}{l|c|c|c|c|c}
\hline \multirow{2}{*}{ Item } & \multicolumn{2}{c|}{$\begin{array}{c}\text { Énfase nos materiais } \\
\text { permanentes (concreto e aço) }\end{array}$} & \multicolumn{2}{c|}{$\begin{array}{c}\text { Énfase na } \\
\text { construtibilidade }\end{array}$} & $\begin{array}{c}\text { Diferença } \\
(\%)\end{array}$ \\
\hline Concreto & $\$ 30,68 / \mathrm{m}^{2}$ & $27 \%$ & $\$ 32,29 / \mathrm{m}^{2}$ & $33 \%$ & $5 \%$ \\
\hline Aço & $\$ 24,22 / \mathrm{m}^{2}$ & $22 \%$ & $\$ 26,91 / \mathrm{m}^{2}$ & $28 \%$ & $11 \%$ \\
\hline Fôrmas & $\$ 56,51 / \mathrm{m}^{2}$ & $51 \%$ & $\$ 37,67 / \mathrm{m}^{2}$ & $39 \%$ & $-33 \%$ \\
\hline Custo total & $\$ \mathbf{1 1 1 , 4 1 / \mathrm { m } ^ { 2 }}$ & $\mathbf{1 0 0 \%}$ & $\mathbf{\$ 9 6 , 8 7 / \mathbf { m } ^ { 2 }}$ & $\mathbf{1 0 0 \%}$ & $\mathbf{- 1 3 \%}$ \\
\hline
\end{tabular}

* Fonte: Ceco Concrete Construction Co. (1985). Concrete Buildings, New Formwork Perspectives. Kansas City, MO.

O decréscimo no custo total em $13 \%$ quando se dá ênfase à construtibilidade, se deve, principalmente, à redução de tempo na fabricação, montagem e desmontagem do sistema de fôrmas, com conseqüente redução nos custos da mão-de-obra. Este, atualmente, é o item mais relevante na composição dos custos de uma obra.

Percebe-se que em alguns escritórios de projetos ainda é comum o uso excessivo de reduções de seções de pilares. Essa prática pode até reduzir a 
quantidade de concreto requerida para o pilar, entretanto as interferências causadas nas fôrmas (pilares, vigas e lajes) com substituições de materiais e mãode-obra despendida a mais para esta alteração, além de aumentar a área de alvenaria, hoje com o custo relativamente maior que o do concreto devido ao encarecimento da mão-de-obra, tornam esta técnica mais dispendiosa. A FIGURA 1.3 ilustra uma possível redução na seção do pilar em sua dimensão maior, caindo de $80 \mathrm{~cm}$ para $60 \mathrm{~cm}$. Através da ilustração é fácil perceber as intervenções causadas nos painéis laterais e de fundo das vigas, painéis da laje, bem como nos painéis dos pilares. Além do tempo gasto com as mudanças, essas podem danificar o sistema de fôrmas, comprometendo sua utilização.

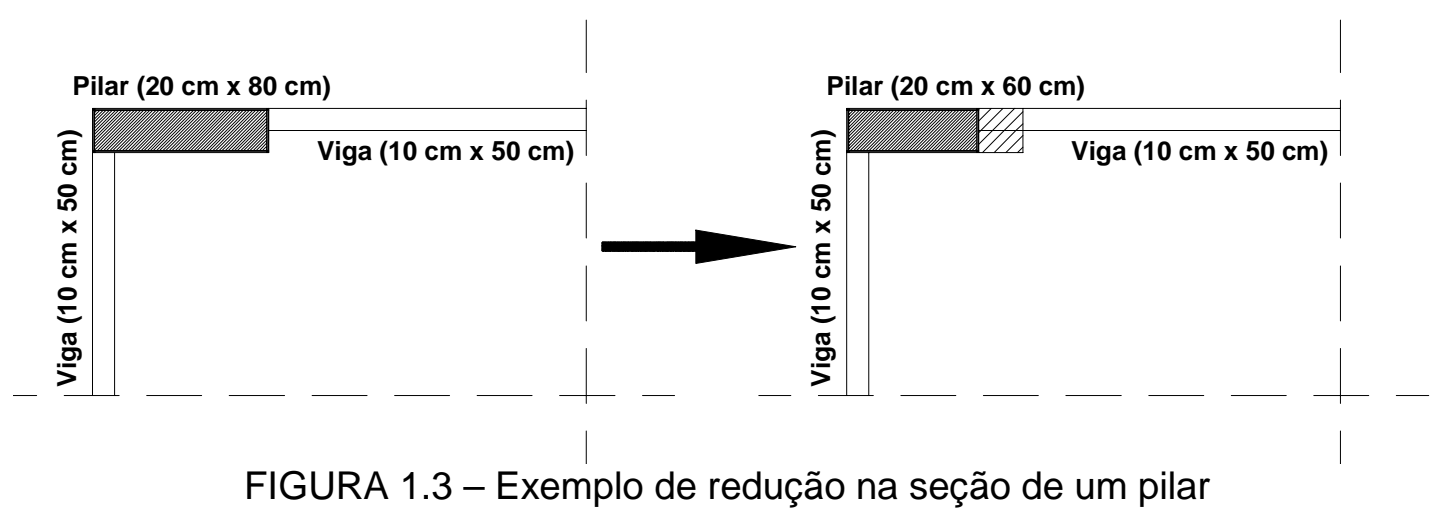

Um exemplo que deixa claro o quanto se pode ter de economia quando se dá prioridade aos aspectos construtivos é o fato de se ter num edifício qualquer, por necessidades estruturais, uma laje no térreo, que servirá de estacionamento, com espessura de $12 \mathrm{~cm}$, e as vigas na sua maioria com seções transversais de $12 \mathrm{~cm} \mathrm{x}$ $65 \mathrm{~cm}$. Com o intuito de se aproveitar as fôrmas no pavimento tipo do edifício e verificando que as lajes, na sua maioria não mais necessitavam de $12 \mathrm{~cm}$, e sim de $9 \mathrm{~cm}$, o projetista de estruturas estabeleceu a seção transversal das vigas do pavimento tipo como $12 \mathrm{~cm} \times 62 \mathrm{~cm}$, evidentemente fundamentado nos cálculos por ele efetuados, com isso pode-se aproveitar todas as faces laterais das fôrmas das vigas. A FIGURA 1.4 ilustra o exemplo citado. 
Viga $(12 \times 65 \mathrm{~cm})$

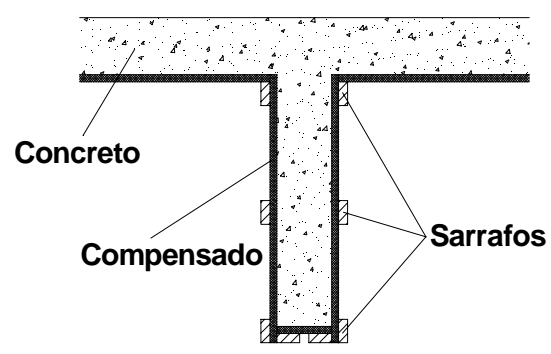

(a)
Viga $(12 \times 62 \mathrm{~cm})$
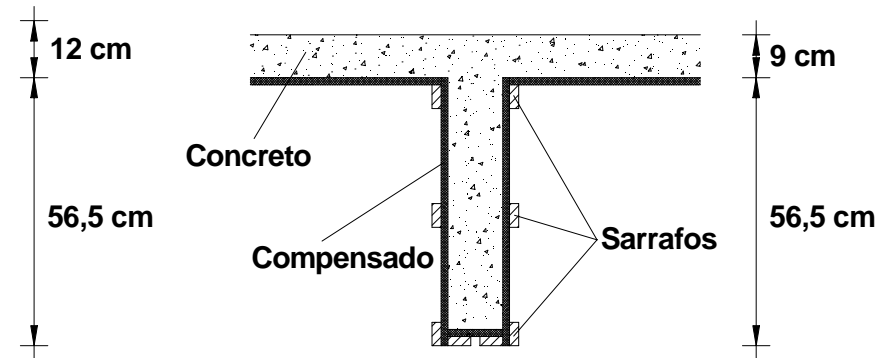

(b)

FIGURA 1.4 - Corte na seção transversal da viga juntamente com a laje: (a) do

térreo que servirá de estacionamento e (b) do pavimento tipo do edifício

Até o momento o que se tem dito é quanto se pode economizar numa edificação quando se pensa na construtibilidade da mesma durante a fase de concepção do projeto, ficou claro que essa redução de custos não só pode como deve ser buscada por parte dos projetistas de estruturas. Entretanto, essa racionalização também pode ser obtida na idealização e planejamento do sistema de fôrmas, através do projeto de fôrmas. Hoje com projetos arquitetônicos cada vez mais ousados, o que torna as estruturas mais complexas, é essencial a contratação de um profissional especialista em fôrmas.

O que se tem geralmente nos edifícios residenciais e/ou comerciais é uma diferença entre os pés-direitos do pavimento tipo para os pavimentos em comum (garagem, lazer, etc.), esses freqüentemente maiores que aqueles. Diante disso, o que se faz é conceber o sistema de fôrmas para o pavimento tipo, por este apresentar um maior número de repetições, com isso faz-se as devidas adaptações para os outros pavimentos. Para ilustrar a situação, tem-se por exemplo para um pilar qualquer, onde no térreo ele apresenta um pé-direito maior que no pavimento tipo. Deve-se ter as faces laterais do pilar projetadas para o pavimento tipo e, então, este recebe um complemento ao ser utilizado no térreo, podendo este complemento (painel em chapa de madeira compensada), ser de um material com qualidade inferior, já que sua utilização vai ser reduzida ou até única. A FIGURA 1.5 , em seguida, apresenta o caso. 


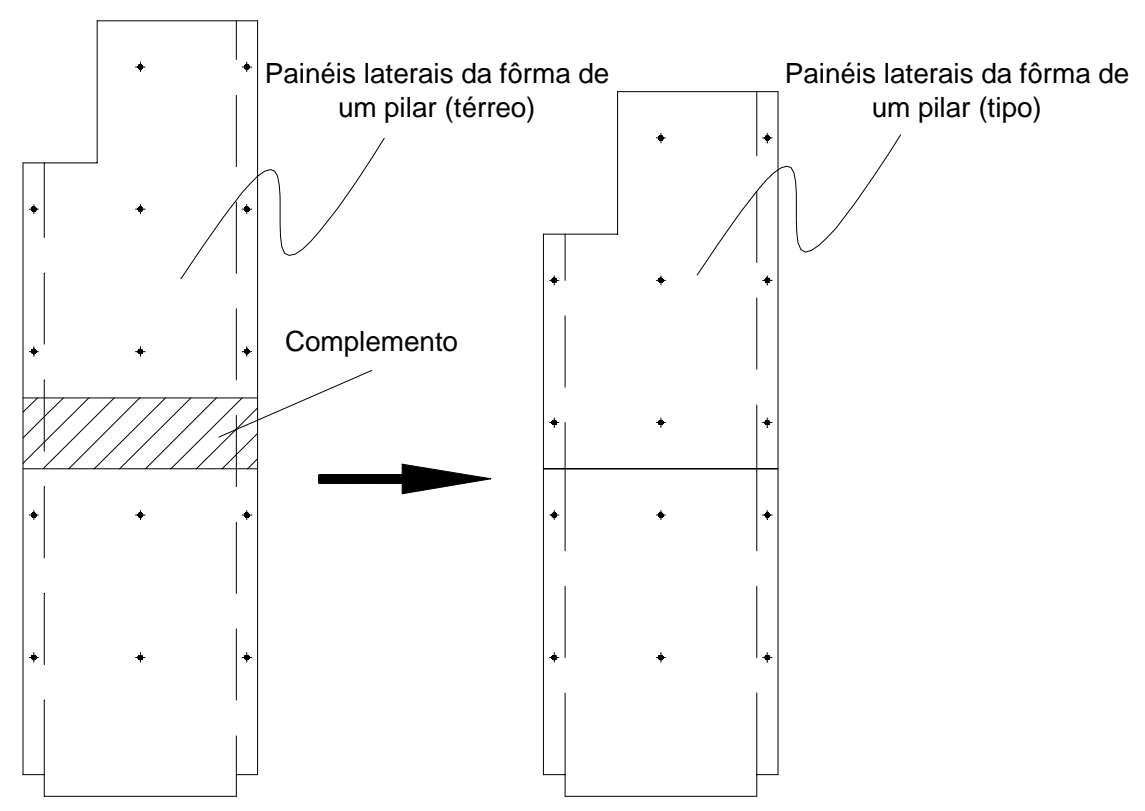

FIGURA 1.5 - Painel lateral da fôrma de um pilar utilizado (a) no térreo com o complemento na parte central e (b) no pavimento tipo, sem o complemento em chapa de madeira compensada

\subsection{Patologias na estrutura em função das fôrmas}

As fôrmas podem ocasionar defeitos indesejáveis nos elementos da estrutura de concreto, que podem afetar sua própria estrutura produzindo vazios, alvéolos, ondulações, deformações, ou efeitos que podem afetar seu aspecto, produzindo mudança de coloração nos concretos que têm que ficar aparentes. Segundo CÁNOVAS (1988) esses efeitos indesejáveis podem ser resumidos nas irregularidades e variações de cor das superfícies do concreto. As irregularidades superficiais podem ser:

cavidades devidas às saliências ou ondulações das fôrmas;

- grupos de cavidades em forma de ninhos de pedras, devidos à segregação, má compactação ou fugas de nata através das juntas da fôrma;

- $\quad$ ondulações devidas à cavidade na superfície da fôrma;

- destacamentos por aderência do concreto à fôrma;

- ataques por desmoldantes não adequados e oxidação de armaduras superficiais que podem degenerar em destacamentos;

- deformações por deficiência no alinhamento da fôrma; 
- falta de retilinidade ou desaprumo das fôrmas dos pilares, paredes, etc.;

- deformação da fôrma sob a carga do concreto fresco; etc.

Quanto às variações de cor nas superfícies do concreto podem ser por:

- contaminação das impurezas das fôrmas;

- $\quad$ má qualidade dos desmoldantes (óleos e graxas, por exemplo);

- $\quad$ diferença de absorção das superfícies das fôrmas;

- $\quad$ perdas de argamassa através das juntas da fôrma; etc.

Além das causas de patologia, anteriormente citadas, existem outras decorrentes de execução e que podem ser consideradas como conseqüência de falta de fiscalização na limpeza; emprego de fôrmas sujas e com restos de argamassa ou pasta de usos anteriores; a não verificação da existência de sujeira quando se vai concretar, colocando janelas na parte inferior das fôrmas de pilares; o não umedecimento ou falta de desmoldantes nas superfícies das fôrmas; etc.

\subsection{Sistemas de fôrmas no mercado}

Muitas tecnologias européias têm chegado ao Brasil e estão incrementando a produtividade na execução das obras através de modernos sistemas de fôrmas. Todas estas fôrmas, normalizadas pelas entidades competentes européias, têm suas vantagens. Apenas devem ser estudadas principalmente com relação à adaptação às necessidades de cada obra.

A simples importação de idéias, conceitos e tecnologias, sejam européias ou americanas, em muitos casos pode não ser satisfatória. É preciso que sejam adequadas à realidade brasileira (social, cultural e técnica). Muitas vezes se buscam equipamentos e tecnologias no exterior a preços elevados, enquanto a melhor solução está ao alcance, bem mais econômicas e em condições de possibilitar melhor desempenho.

Em decorrência da grande disseminação da construção de estruturas de concreto, surgiu a necessidade de otimizar a utilização das fôrmas, visando diminuir custos e melhorar a qualidade final das estruturas. Nesta análise, o fundamental é a busca do equilíbrio entre custo, qualidade e prazo, variáveis importantes num processo que envolve preço e qualidade do produto final aos consumidores. A opção por sistemas de fôrmas racionalizados envolve variáveis complexas, 
podendo ser adotados os mais diversos sistemas de fôrmas disponíveis no mercado.

Torna-se importante um estudo detalhado de cada obra antes de definir o sistema a ser adotado. A identificação do tipo ideal de sistema e processo consegue maior equilíbrio, unindo a experiência do profissional especializado em fôrmas, ainda raro no mercado de trabalho da engenharia brasileira, com o sentimento e a experiência dos responsáveis da empresa contratante (construtoras).

\subsection{Sistema de fôrmas a ser estudado: terminologia e definições}

O sistema de fôrmas a ser estudado no presente trabalho será o convencional, com chapas compensadas resinadas e/ou plastificadas, por ser 0 produto mais utilizado para a fabricação dos painéis, isto pode ser explicado pela facilidade em se obter qualquer formato desejado para o painel, e também pelo baixo peso, propiciando facilidade de movimentação. $O$ cimbramento será misto (escoras metálicas e/ou em madeira) e acessórios metálicos, o que proporciona um maior número de reutilizações, e/ou de madeira, com um número menor de reutilizações. A experiência dos profissionais dessa área aponta que este sistema é o mais indicado para as obras com o cronograma mais apertado e fluxo de caixa definido. Embora muito difundido, o que se tem visto é a utilização deste sistema de fôrmas de maneira não racionalizada.

O fato de se utilizar acessórios em madeira ou metálicos não trará maiores complicações, pois os métodos de análise apresentados poderão ser utilizados tanto para um como para o outro material, apenas com pequenas adaptações.

O presente trabalho será aplicado aos edifícios de múltiplos andares (residencial e comercial). As partes atípicas da estrutura (fundações, escadas, etc.) não serão enfatizadas, por se entender que, para essas, as influências construtivas terão mais importância do que os problemas estruturais.

De acordo com FAJERSZTAJN (1987), pode-se analisar as fôrmas subdividindo-se o Sistema de Fôrmas em Subsistemas, Elementos e Componentes.

Sistema de Fôrmas é o conjunto das fôrmas utilizadas para moldar a estrutura de concreto armado do edifício. 




FIGURA 1.6 - Subsistema de Fôrmas para as lajes

Subsistema de Fôrmas pode ser entendido como sendo o conjunto de fôrmas destinado a moldar determinadas partes ou tipos de peças da estrutura de concreto armado do edifício. Assim têm-se subsistemas de fôrmas para lajes (FIGURA 1.6), vigas (FIGURA 1.7) e pilares (FIGURA 1.8). A divisão em subsistemas é feita de acordo com a função que desempenham as peças na estrutura. As características e os esforços a que cada uma das peças dos subsistemas são submetidas são afetadas pela finalidade de cada subsistema no todo. 




FIGURA 1.7 - Subsistema de Fôrmas para as vigas

Os Elementos são conjuntos de peças que exercem função determinada dentro do subsistema de fôrmas. São classificadas de acordo com a finalidade em molde, estrutura do molde, escoramento e acessórios. O molde é o elemento que entra em contato direto com o concreto, definindo o formato e a textura concebidas respectivamente pelo projetista de estrutura e pelo arquiteto. A estrutura do molde destina-se a enrijecer o molde, garantindo que ele não se deforme quando submetido aos esforços. O escoramento tem como função transmitir os esforços da estrutura do molde para algum ponto de suporte do solo ou na própria estrutura. E, os acessórios são o conjunto de peças complementares destinadas a completar os demais elementos na confecção das fôrmas. 




FIGURA 1.8 - Subsistema de Fôrmas para os pilares

Por fim, os Componentes, são as diferentes peças que compõem os elementos. Em nível de peça pronta se constituem na última decomposição das fôrmas.

A terminologia agora apresentada se aplica para um modelo de sistema de fôrmas genérico. Um modelo particular poderá ter uma nomenclatura específica, principalmente para os componentes. A TABELA 1.2 descreve de maneira sucinta 0 sistema de fôrmas a ser estudado. 
TABELA 1.2 - Sistema de Fôrmas a ser estudado

\begin{tabular}{|c|c|c|}
\hline \multicolumn{3}{|c|}{ Sistema de Fôrmas } \\
\hline Subsistema & Elementos & Componentes \\
\hline \multirow{4}{*}{ Lajes } & Molde & painéis \\
\hline & Estrutura do molde & transversinas e longarinas \\
\hline & Escoramento & $\begin{array}{l}\text { pontaletes de madeira, } \\
\text { escoras metálicas, } \\
\text { travamentos, torres, } \\
\text { contraventamentos, etc. }\end{array}$ \\
\hline & Acessórios & $\begin{array}{l}\text { para estruturação } \mathrm{e} \\
\text { nivelamento }\end{array}$ \\
\hline \multirow{4}{*}{ Vigas } & Molde & painéis de faces e fundo \\
\hline & Estrutura do molde & sarrafos \\
\hline & Escoramento & $\begin{array}{l}\text { garfos, pontaletes de } \\
\text { madeira, escora metálica, } \\
\text { torres, etc. }\end{array}$ \\
\hline & Acessórios & $\begin{array}{l}\text { para estruturação } \mathrm{e} \\
\text { nivelamento }\end{array}$ \\
\hline \multirow{4}{*}{ Pilares } & Molde & painéis laterais \\
\hline & Estrutura do molde & $\begin{array}{l}\text { guias de amarração e } \\
\text { gravatas }\end{array}$ \\
\hline & Escoramento & $\begin{array}{l}\text { aprumadores, mão } \\
\text { francesa e niveladores }\end{array}$ \\
\hline & Acessórios & $\begin{array}{l}\text { para estruturação } \\
\text { nivelamento }\end{array}$ \\
\hline
\end{tabular}

\subsection{Objetivos e justificativas}

O considerável uso do concreto em estruturas e a ousadia dos projetos arquitetônicos, que exigem cada vez mais peças esbeltas e de acabamento impecável, determinaram, nos últimos tempos, a necessidade de uma sofisticação das fôrmas para concretagem.

O esforço para a produção de um bom sistema de fôrmas é tão importante quanto o dedicado à elaboração do projeto de estruturas. As fôrmas numa estrutura 
de concreto têm um impacto significativo no custo, tempo e qualidade do projeto final.

Diante do exposto, torna-se justificável a importância de um planejamento e projeto de fôrmas para as estruturas de concreto armado. Estes devem analisar e estudar os desenhos geométricos das estruturas a construir, definindo o esquema mais econômico para cada caso. A fôrma é a estrutura auxiliar que pode valorizar ou frustar um empreendimento, dependendo de que maneira foi concebida. Devem também ser mencionados os novos materiais, bem como a caracterização de suas propriedades mecânicas, e a renovação das regras normalizadoras, com a chegada da NBR 7190 (1997) - "Projeto de Estruturas de Madeira".

A proposta deste trabalho é apresentar os princípios e técnicas para a análise e projeto das fôrmas para estruturas de concreto. Nesse contexto, numa primeira fase, a partir de ensaios experimentais realizados nas faces laterais das fôrmas de pilares, estima-se a pressão lateral que o concreto exerce nessas paredes, sendo a medida feita através de extensômetros elétricos fixados nos tensores. O diagrama de pressões laterais é necessário para o dimensionamento de peças integrantes das fôrmas. Numa segunda fase, estuda-se um sistema de fôrmas para edifícios de múltiplos andares (residencial ou comercial), que proporcione maior racionalização, face à análise das diversas opções de sistemas existentes, seja no âmbito nacional ou internacional, apresentando os métodos de análise dos vários componentes do sistema de fôrmas.

Baseado nas análises pretendidas anteriormente, o trabalho termina com as premissas necessárias para a elaboração projetual de um sistema de fôrmas para edifícios de múltiplos andares, utilizando-se a versão da norma NBR 7190 (1997), fundamentada no método dos estados limites.

$\mathrm{Na}$ execução de uma edificação, normalmente dispõe-se de uma série de elementos gráficos que constituem o projeto do edifício. No caso mais geral são elaborados os projetos de arquitetura, de estrutura e fundações, de instalações elétricas e hidráulicas. De posse destes projetos o construtor pode conduzir a obra. Entretanto, ainda não está generalizada no país a apresentação, junto da documentação normal de projeto de uma edificação, do projeto de fôrmas.

O trabalho ora apresentado pretende alertar a indústria da construção civil, atentando o meio técnico e científico para a disseminação e desenvolvimento de engenheiros e projetistas especializados em projeto de fôrmas, constituindo uma importante área de especialização dentro do campo da Engenharia Civil. 


\subsection{Organização do trabalho}

No Capítulo 2 são apresentadas as características intrínsecas das chapas de madeira compensada, como etapas de produção, classificação, especificação, propriedades mecânicas e físicas, entre outras. Por ser o material mais utilizado como molde nas fôrmas para concreto, é importante que o projetista o conheça bem, para melhor especificá-lo.

No Capítulo 3 são estudadas as ações a que estão sujeitos os sistemas de fôrmas, auxiliando os projetistas na definição dos carregamentos. Torna-se essencial uma definição coerente das ações a que estão submetidas as fôrmas para a elaboração do projeto.

O Capítulo 4 apresenta a parte experimental do trabalho, a partir de ensaios experimentais realizados nas faces laterais das fôrmas de pilares, estima-se a pressão lateral que o concreto exerce nessas paredes, sendo a medida feita através de extensômetros elétricos fixados nos tensores. O diagrama de pressões laterais é necessário para o dimensionamento das peças integrantes das fôrmas.

No Capítulo 5 são tratados todos os procedimentos de dimensionamento das fôrmas, estes baseados na norma NBR 7190 (1997) - Projeto de Estruturas de Madeira. Com a profunda reformulação da norma NBR 7190 (1982), originariamente NB 11 (1951), baseada no método das tensões admissíveis, para a nova versão da norma brasileira NBR 7190 (1997), fundamentada no método dos estados limites, torna-se necessário esclarecer os pontos relevantes que norteiam esta transição.

No Capítulo 6 são apresentadas disposições construtivas que auxiliam tanto na fase projetual, como de execução. O capítulo também esclarece sobre as ações construtivas a que estão submetidas as estruturas dos edifícios de concreto armado (a partir da fase de concretagem), através de um estudo do escoramento e reescoramento das estruturas (Método de Grundy e Kabaila).

O Capítulo 7, de acordo com as análises obtidas anteriormente, são apresentadas regras gerais de elaboração do projeto e desenhos de fôrmas baseados nas recomendações da NBR 10067 (1995), e também práticas.

No Capítulo 8 apresentam-se as conclusões gerais do trabalho. 


\section{Chapas de Madeira Compensada}

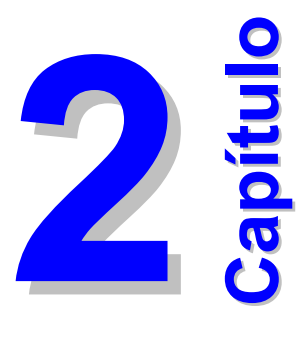

\subsection{Generalidades}

A madeira extraída das toras das árvores são limitadas quanto às dimensões, principalmente na largura das peças obtidas. No mercado, as peças mais largas que se encontram facilmente são as tábuas de $30 \mathrm{~cm}$ de largura. Essa dimensão impõe uma restrição quanto à montagem de painéis de fôrmas.

Assim surgiu a madeira compensada, idealizada por um engenheiro francês no início do século $X X$, tornando-se um elemento de grande importância e eficiente na construção civil. Foi a partir daí então, que o compensado* começou a ser industrialmente produzido. Esta produção se iniciou, de acordo com VAZ (1987), na Alemanha e nos Estados Unidos, a partir de algumas espécies de madeira de baixa densidade. Atualmente são utilizados a maioria das espécies de madeira comercialmente importantes, tendo sua utilização difundida e solidamente

\footnotetext{
" No decorrer do texto, oportunamente, "chapa de madeira compensada" e/ou "madeira compensada", poderá ser designado pelo termo "compensado".
} 
estabelecida em muitos países desenvolvidos, como Alemanha, Austrália, Estados Unidos e outros.

Uma das grandes vantagens da utilização das chapas de madeira compensada é a possibilidade de se trabalhar com elementos de grandes dimensões e que podem alcançar altos valores de resistência se comparados à resistência da madeira sã utilizada na fabricação do compensado.

As características de resistência da madeira compensada: resistência à tração, compressão, cisalhamento, fendilhamento, estabilidade dimensional e resistência ao impacto, tornam este material bastante adequado para fechamentos, pisos, paredes divisórias internas, coberturas, etc., sendo utilizado, em composição com a madeira maciça, em vários elementos estruturais. No entanto, este trabalho vai estudar a utilização das chapas de madeira compensada no emprego nas fôrmas para concreto.

\subsection{Etapas de produção das chapas de madeira compensada}

A seqüência das etapas descritas a seguir, está baseada no texto de OLIVEIRA \& FREITAS (1995) apud STAMATO (1998).

Primeiramente as toras devem ser descascadas e acondicionadas em tanques contendo vapor ou água quente para que as mesmas se tornem amolecidas e de maior plasticidade, o que propicia a obtenção de lâminas menos quebradiças e mais lisas.

As lâminas de madeira são obtidas através de um dispositivo mecânico que permite prender a tora pelas extremidades, imprimindo um movimento de rotação em relação ao seu eixo e, através de uma faca afiada, obtém-se uma lâmina de madeira contínua. Esta emerge entre a faca e a contra-faca (ou barra de pressão), sendo a função da contra-faca exercer pressão sobre a madeira para prevenir a formação de fendas ou arrancamento de fibras nas lâminas produzidas. A FIGURA 2.1 ilustra de modo esquemático um torno laminador com uma tora sendo desenrolada e as suas respectivas partes. 


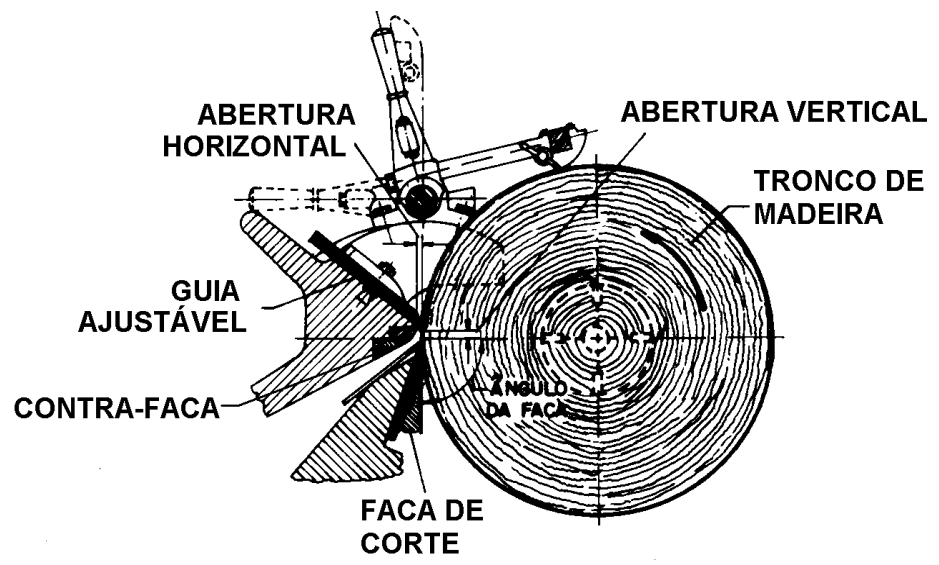

FIGURA 2.1 - Obtenção das lâminas por corte rotatório [Fonte: VAZ (1987)]

Após serem produzidas no torno, as lâminas são transportadas por esteiras a uma bancada com uma guilhotina, onde as lâminas verdes são cortadas em tamanhos padrões. Logo depois se faz a secagem das lâminas com o objetivo de reduzir sua umidade a um teor predeterminado. A secagem é feita em um tempo muito reduzido (alguns minutos), e o teor de umidade final também é baixo, ou seja, por volta de $4 \%$ a $6 \%$ de teor de umidade.

As lâminas secas devem ser empilhadas de acordo com a largura e classe. Devem ser classificadas visualmente por pessoas treinadas, levando em consideração o tipo e tamanho dos defeitos, bem como as características da grã das várias lâminas.

Lâminas com espessuras equivalentes são colocados umas sobre as outras, de modo que duas lâminas adjacentes estejam cruzadas entre si, ou seja, as fibras dessas duas lâminas estejam em direções ortogonais, o que dará ao compensado uma resistência à flexão maior que uma peça similar em madeira maciça. Normalmente, as chapas de madeira compensada são fabricadas com número ímpar de lâminas, buscando obter uma equivalência das propriedades elásticas e da resistência nas direções principais da chapa.

As lâminas externas ou lâminas de face (capas), das chapas de madeira compensada, possuem as fibras paralelas à maior dimensão ou maior comprimento da chapa. Outra melhoria, quando na utilização de lâminas sobrepostas ortogonalmente, é a eliminação dos defeitos mais significativos da madeira, reconstituindo o material.

A junção das lâminas é feita através de adesivos sintéticos, onde o mais utilizado é o fenol-formaldeído, formando nesta colagem um elemento monolítico. 
Geralmente, os adesivos são aplicados através de um conjunto de rolos, todos revestidos de borracha, que têm a função básica de espalhar os adesivos, além de dosar a espessura desejada da camada de adesivo nas lâminas.

Imediatamente após o adesivo ser aplicado nas lâminas, deve-se proceder à montagem do compensado, seguido do carregamento da prensa. No caso da prensagem a frio, a pressão pode variar de 0,6 MPa a 1,0 MPa. E, no caso da utilização de uma prensa aquecida, a pressão de colagem pode variar de 1,2 MPa a 2,0 MPa.

Quanto ao acabamento da superfície, encontram-se chapas com as faces externas lixadas e com um tratamento superficial, outras possuem uma película plástica nas lâminas externas, ou somente numa.

Os compensados resinados recebem em sua superfície a aplicação de uma resina fenólica líqüida, que é estendida sobre a mesma. As laterais também recebem o mesmo material aplicado à superfície. Esse tipo de revestimento não sofre um processo de polimerização eficiente, e a proteção que oferece à chapa é bastante precária, já que a resina, aos poucos, durante os processos de concretagem, vai sendo retirada de sua superfície. Dessa forma, o número de reaproveitamentos de um mesmo painel fica reduzido (geralmente de 4 a 5 usos).

Os compensados plastificados recebem em sua superfície uma camada de resina fenólica sob a forma de filme (Tego-Film). As laterais são totalmente seladas com resina do tipo epoxi ou similar, a prova d'água. Dessa forma obtém-se um compensado com vida útil que atende a um determinado número de reaproveitamentos, além de contribuir para o bom acabamento da superfície do concreto. Estes, de acordo com BOIN (1993), podem chegar a 40 reaproveitamentos, dependendo da finalidade ou do tipo de estrutura que se pretende executar. A FIGURA 2.2 ilustra todas as etapas de produção das chapas de madeira compensada. 


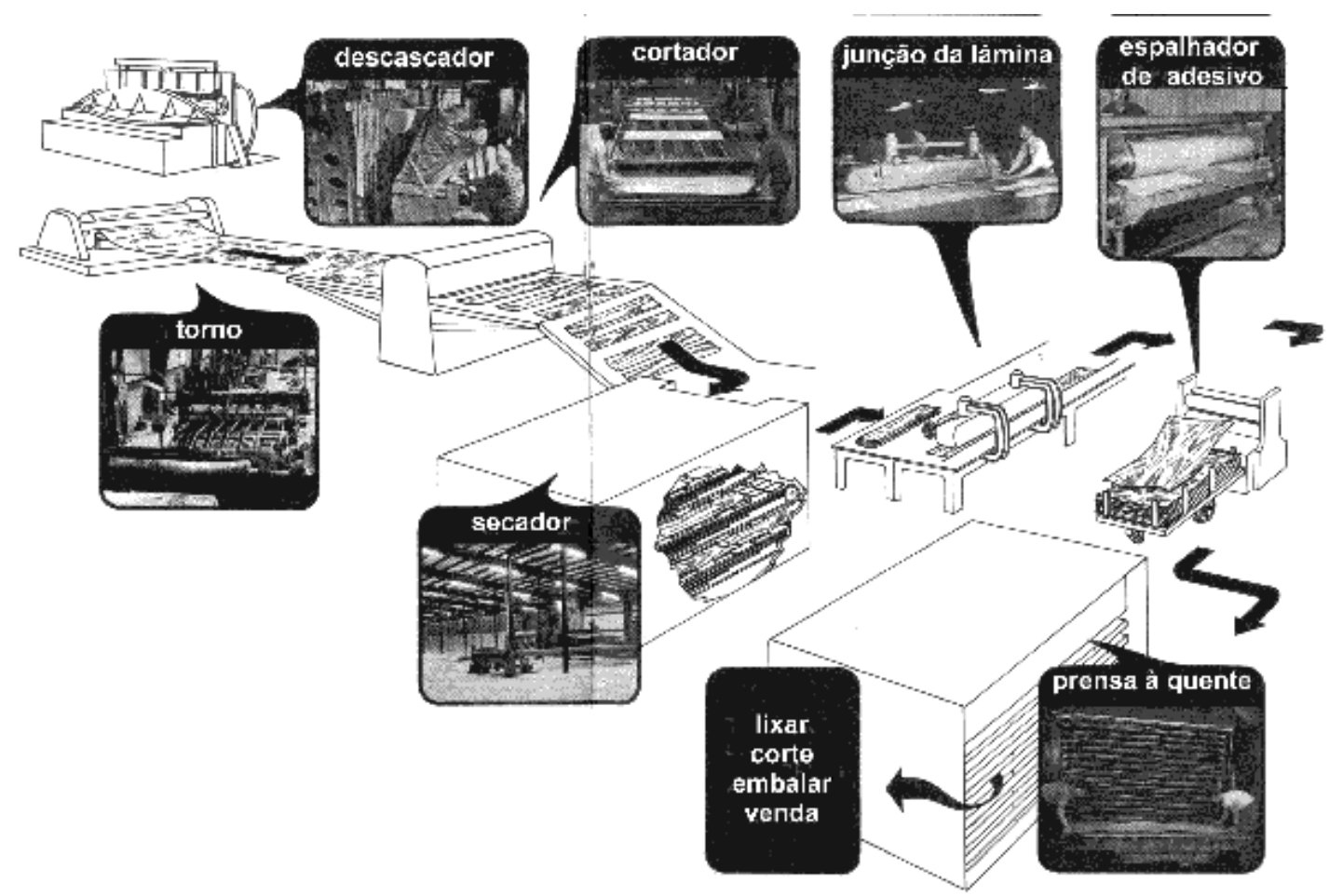

FIGURA 2.2 - Etapas de produção das chapas de madeira compensada [(Fonte:

HPMA apud STAMATO(1998)]

\subsection{Classificação e especificação das chapas de madeira compensada}

As chapas de madeira compensada para fôrmas devem atender às disposições das normas NBR 9531 (1985) - Chapas de madeira compensada Classificação e a NBR 9532 (1986) - Chapas de madeira compensada Especificação, da ABNT, não devendo apresentar defeitos sistemáticos tais como desvios dimensionais além dos limites tolerados, número de lâminas inadequado à sua espessura, desvios no esquadro ou defeitos nas superfícies. Também devem ser resistentes à ação da água.

As dimensões corretas das chapas são de 1,10 m x 2,20 m para chapas resinadas e 1,22 $\mathrm{m} \times 2,44 \mathrm{~m}$ ou 1,10 $\mathrm{m} \times 2,20 \mathrm{~m}$ para chapas plastificadas, com espessuras de $6 \mathrm{~mm}, 9 \mathrm{~mm}, 12 \mathrm{~mm}, 18 \mathrm{~mm}$ ou $21 \mathrm{~mm}$. As chapas são classificadas nos subgrupos $A, B$ e $C$ em função, principalmente, da área de defeitos superficiais que apresentam.

Cada viagem para entrega de chapas será considerada um lote, desde que não exceda a 500 chapas de um mesmo tipo. No caso de entrega de mais de 500 
chapas por viagem, a remessa deverá ser dividida de tal forma que resultem lotes aproximadamente iguais e, ao mesmo tempo, com menos de 500 chapas. A amostra a ser retirada de cada lote será formada por 13 chapas escolhidas aleatoriamente.

O controle é exercido em obra, verificando-se as chapas de compensado conforme orientações e limites apresentados na TABELA 2.1. As verificações devem ser feitas nas 13 chapas que compõem a amostra, anotando-se, para cada verificação, o número de chapas defeituosas encontradas.

Para as verificações dimensionais (comprimento, largura, espessura e esquadro) e verificações visuais (presença de emendas, aspecto superficial e aspecto das bordas) deve-se conferir as 13 chapas que compõem a amostra, aceitando o lote inteiro caso não sejam encontradas chapas defeituosas. Se houver quatro ou mais peças com defeito, deve-se rejeitar o lote. Encontrando-se até três peças com defeito, deve-se inspecionar uma segunda amostra formada por mais 13 peças. Nesse caso, para a aceitação do lote, o número total de chapas defeituosas das duas amostras somadas deve ser menor ou igual a três.

Em caso de rejeição na segunda amostragem, deve-se inspecionar o lote inteiro e devolver as chapas defeituosas.

Para o número de lâminas deve-se verificar a chapa escolhida como amostra, aceitando o lote caso o número de lâminas esteja de acordo com o mínimo estabelecido na TABELA 2.1. Se o número de lâminas resultar menor que o mínimo, deve-se devolver o lote inteiro.

Quanto à resistência à ação da água, o lote é aceito se nove dos dez corpos-de-prova, retirados de uma chapa de amostra, passarem no teste. Caso seja reprovado, o lote inteiro deve ser devolvido.

TABELA 2.1 - Tolerâncias segundo as características das chapas de madeira compensada

\begin{tabular}{l|l|l}
\hline \multicolumn{1}{c|}{ Característica } & Tolerância & \multicolumn{1}{|c}{$\begin{array}{l}\text { Equipamento ou meio de } \\
\text { verificação }\end{array}$} \\
\hline \multirow{2}{*}{ Comprimento } & $\pm 2 \mathrm{~mm}$ & $\begin{array}{l}\text { Trena metálica com } \\
\text { precisão de } 1 \quad \mathrm{~mm}, \\
\text { tomando-se a medida no } \\
\text { meio da chapa. }\end{array}$ \\
\hline Largura & $\pm 2 \mathrm{~mm}$ & Trena metálica com \\
\hline
\end{tabular}




\begin{tabular}{|c|c|c|}
\hline & & $\begin{array}{l}\text { precisão de } 1 \mathrm{~mm} \text {, } \\
\text { tomando-se a medida no } \\
\text { meio da chapa. }\end{array}$ \\
\hline Espessura & $\pm 1 \mathrm{~mm}$ & $\begin{array}{l}\text { Paquímetro com precisão } \\
\text { de } 0,1 \mathrm{~mm} \text {, tomando-se a } \\
\text { medida num ponto sem } \\
\text { defeitos visuais, a pelo } \\
\text { menos } 30 \mathrm{~mm} \text { da borda da } \\
\text { chapa. }\end{array}$ \\
\hline $\begin{array}{l}\text { Esquadro: } \\
\text { - Chapa }(1,22 \mathrm{~m} \times 2,44 \mathrm{~m}) \\
\text { com diagonal de } 272,8 \\
\mathrm{~mm} \text {; } \\
\text { - Chapa }(1,10 \mathrm{~m} \times 2,20 \mathrm{~m}) \\
\text { com diagonal de } 246 \\
\mathrm{~mm} \text {. }\end{array}$ & $\pm 5 \mathrm{~mm}$ & $\begin{array}{l}\text { Trena metálica com } \\
\text { precisão de } 1 \mathrm{~mm} \text {, } \\
\text { tomando-se as medidas } \\
\text { nas diagonais da chapa. }\end{array}$ \\
\hline $\begin{array}{l}\text { Número de lâminas*: } \\
\text { - } \quad \text { Chapas de } 6 \mathrm{~mm} ; \\
\text { - } \quad \text { Chapas de } 9 \text { ou } 12 \mathrm{~mm} \text {; } \\
\text { - Chapas de } 18 \mathrm{~mm} ; \\
\text { - Chapas de } 21 \mathrm{~mm} \text {. }\end{array}$ & $\begin{array}{l}\text { Número mínimo de } \\
\text { lâminas: } \\
3 \\
5 \\
7 \\
9\end{array}$ & $\begin{array}{l}\text { Contagem visual pela } \\
\text { borda da chapa. }\end{array}$ \\
\hline Presença de emendas & $\begin{array}{l}\text { - } \text { Resinado: até } 2 \\
\text { emendas, tanto na } \\
\text { face quanto na } \\
\text { contraface; } \\
\text { - Plastificado: } \\
\text { máximo de } 1 \\
\text { emenda por chapa. }\end{array}$ & Verificação visual. \\
\hline Aspecto superficial & $\begin{array}{l}\text { - } \text { Resinado: faces } \\
\text { firmes, sem falhas } \\
\text { que prejudiquem } \\
\text { seu uso; } \\
\text { - Plastificado: filme }\end{array}$ & Verificação visual. \\
\hline
\end{tabular}




\begin{tabular}{|c|c|c|}
\hline & $\begin{array}{l}\text { contínuo, liso e } \\
\text { sem falhas ou } \\
\text { incrustações. }\end{array}$ & \\
\hline Aspecto das bordas & $\begin{array}{l}\text { Devem estar seladas, } \\
\text { sem apresentar } \\
\text { deslocamento das } \\
\text { lâminas. }\end{array}$ & Verificação visual. \\
\hline Resistência à água & $\begin{array}{l}\text { Não devem apresentar } \\
\text { deslocamento das } \\
\text { lâminas após imersão } \\
\text { ou fervura em água. }\end{array}$ & $\begin{array}{l}\text { Tomar uma chapa de } \\
\text { amostra e retirar } 10 \\
\text { corpos-de-prova de } 10 \mathrm{~cm} \\
\text { x } 10 \mathrm{~cm} \text {. Imergi-los em } \\
\text { água limpa por } 12 \text { horas, } \\
\text { deixar secando ao sol por } \\
12 \text { horas e imergi-los } \\
\text { novamente por mais } 12 \\
\text { horas. } \\
\text { disponibilidade } \\
\text { fogareiro, este teste, que } \\
\text { tem } 36 \text { horas de duração, } \\
\text { pode ser substituído pela } \\
\text { fervura dos corpos-de- } \\
\text { prova em água limpa por } \\
10 \text { minutos. }\end{array}$ \\
\hline
\end{tabular}

* Para verificação do número de lâminas deve-se tomar apenas uma chapa de amostra.

As chapas de madeira compensada utilizadas como fôrmas para concreto, de acordo com a NBR 9532 (1986), deverão apresentar um módulo de elasticidade mínimo de $4000 \mathrm{MPa}$. 


\subsection{Propriedades mecânicas e físicas das chapas de madeira compensada}

A laminação cruzada do compensado resulta em propriedades físicas e mecânicas mais desejáveis para a utilização estrutural. A resistência da madeira na direção paralela às fibras é muitas vezes maior que na direção perpendicular. $A$ construção com fibras cruzadas, utilizada no compensado, aumenta significativamente a resistência e a rigidez na direção normal às fibras, se comparado com a madeira maciça. Portanto, painéis de compensado possuem boa rigidez e resistência nas direções perpendicular e paralela às fibras da lâmina da face. STAMATO (1998) apresenta alguns fatores que podem influenciar nas propriedades da resistência e rigidez das chapas de madeira compensada:

- Fatores geométricos (número e espessura das lâminas e composição);

- Material (espécie de madeira e teor de umidade);

- Fatores de carga (tipo de carregamento, direção das tensões em relação às fibras das lâminas de face do compensado e duração da carga);

É importante notar que na utilização de chapas de madeira compensada nas fôrmas para concreto, o estudo de flexão se dará sempre no plano do painel.

As propriedades de resistência e rigidez do painel de compensado são dependentes da direção das lâminas, das propriedades das espécies de madeira e do adesivo que compõem o compensado.

O compensado com número ímpar de lâminas, com o posicionamento alternado das lâminas, formando um ângulo reto em relação às fibras, pode ser considerado, para análise estrutural, como um material plano ortotrópico, ou seja, com simetria elástica, em relação a dois planos perpendiculares, sendo, como todo material ortotrópico, caracterizado por propriedades direcionais.

Devido ao corte rotatório das toras, o plano das lâminas coincide com o plano longitudinal-tangencial da madeira. Segundo BODIG \& JAYNE (1982), a variação dos parâmetros elásticos e de resistência de uma lâmina de madeira neste plano (longitudinal-tangencial) pode ser representada, para o caso do módulo de elasticidade, por um gráfico de coordenadas polares. A FIGURA 2.3 ilustra a variação do módulo de elasticidade atingindo valor máximo na direção longitudinal e mínimo na direção tangencial. 


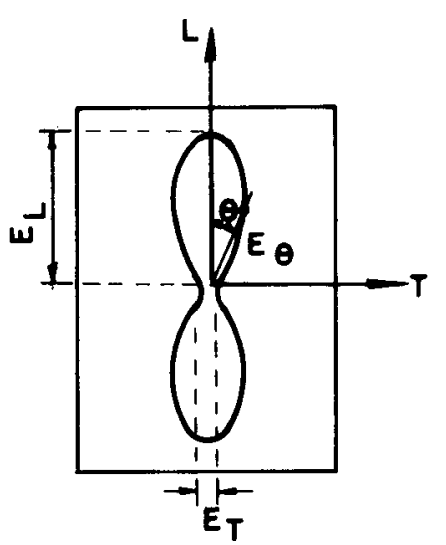

FIGURA 2.3 - Variação dos parâmetros característicos das lâminas de madeira no plano longitudinal-tangencial [Fonte: BODIG \& JAYNE (1982)]

Esta eficiência pode ser observada pela análise dos parâmetros de uma chapa, em função do número e direção das lâminas. A FIGURA 2.4a mostra, em linha cheia, a variação do módulo de elasticidade médio da composição ortogonal de duas lâminas de madeira de mesma espécie e espessura, baseada na variação do módulo de elasticidade destas lâminas (FIGURA 2.3). Observa-se que os valores mínimos do módulo de elasticidade ocorrem nas direções de $45^{\circ} \mathrm{com}$ os eixos longitudinal e transversal.

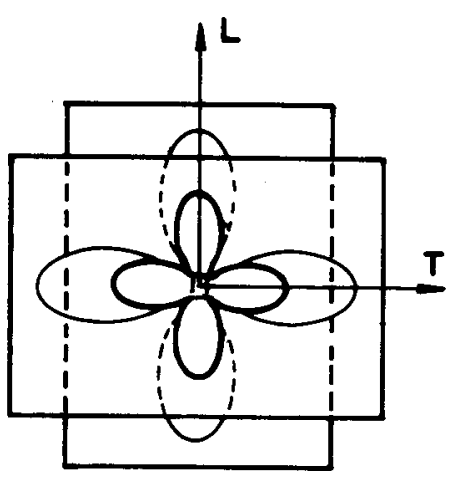

(a)

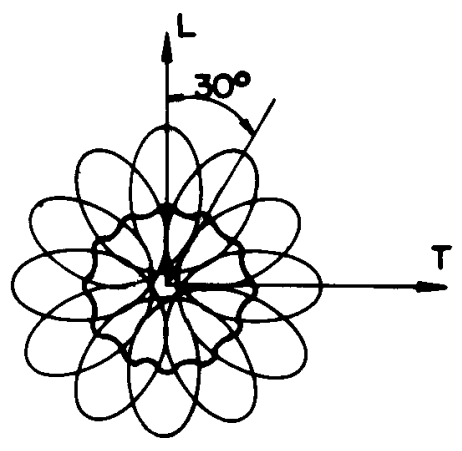

(b)

FIGURA 2.4 - Composição das lâminas e variação dos parâmetros elásticos dos compostos obtidos [Fonte: BODIG \& JAYNE (1982)] 
Na FIGURA 2.4b é apresentado, também em linha cheia, o diagrama para uma composição de lâminas, onde a direção das fibras nas lâminas é desalinhada de um ângulo de $30^{\circ}$. Neste caso, consegue-se um valor do módulo de elasticidade quase constante, aproximando-se assim a isotropia do material [BODIG \& JAYNE (1982) apud STAMATO (1998)].

A análise das propriedades elásticas do compensado é baseada no conhecimento dos parâmetros elásticos de cada lâmina isolada. As lâminas são consideradas homogêneas, isto é, os seus parâmetros elásticos são constantes, ao longo e através da espessura da lâmina.

No caso das chapas de madeira compensada funcionarem como placas e sua análise ser feita como tal, é importante deixar claro que as tabelas comumente encontradas na literatura são para materiais isotrópicos, entretanto, as chapas compensada têm o funcionamento de um material ortotrópico.

O teor de umidade de equilíbrio do compensado com o ambiente é menor que o da madeira maciça, devido às linhas de cola. Assim como a madeira sólida, as lâminas são higroscópicas e, portanto, o teor de umidade do compensado depende das condições climáticas do ambiente a que está exposto (TABELA 2.2).

TABELA 2.2 - Teor de umidade de equilíbrio à temperatura de $20^{\circ} \mathrm{C}$ [Fonte:

STECK (1995) apud STAMATO (1998)]

\begin{tabular}{l|c|c|c}
\hline Umidade relativa do ar & $30 \%$ & $65 \%$ & $85 \%$ \\
\hline Chapa de Madeira Compensada & $\sim 5 \%$ & $\sim 10 \%$ & $\sim 15 \%$ \\
\hline Madeira maciça (leve) & $\sim 6 \%$ & $\sim 12 \%$ & $\sim 17 \%$ \\
\hline
\end{tabular}

\subsection{Curvatura das chapas de madeira compensada}

Nas peças curvas, quando se usa o compensado, para o melhor resultado é conveniente saber como se comportam essas placas, e quais as suas limitações.

Há uma prática de se efetuarem cortes na face tracionada, de pequena profundidade em relação à espessura do painel, reduzindo-lhe os momentos resistentes e de inércia, o que permitirá impor maiores deformações, ou curvá-los, com raios menores.

Outra maneira de resolver o problema de modo bem definido, é empregar um número maior de painéis de menor espessura, com possibilidade de curvaturas iguais. 
Quando se utiliza a chapa de madeira compensada inteira de maneira encurvada, torna-se imprescindível saber quais as limitações para tal comportamento. A TABELA 2.3 apresenta os raios de curvatura mínimo de acordo com a espessura da chapa. Os raios de curvatura mostrados são apenas valores médios de alguns fabricantes de chapas compensadas.

TABELA 2.3 - Raios de curvatura mínimo de acordo com a espessura da chapa

\begin{tabular}{c|c|c}
\hline $\begin{array}{c}\text { Espessura da chapa } \\
\text { compensada }(\mathrm{mm})\end{array}$ & $\begin{array}{c}\text { Raio de curvatura } \\
\text { perpendicular às fibras }(\mathrm{cm})\end{array}$ & $\begin{array}{c}\text { Raio de curvatura paralelo } \\
\text { às fibras }(\mathrm{cm})\end{array}$ \\
\hline 6 & 60 & 150 \\
\hline 9 & 90 & 240 \\
\hline 12 & 180 & 360 \\
\hline 18 & 360 & 600 \\
\hline
\end{tabular}

\subsection{Orientações para o armazenamento e compra das chapas de madeira compensada}

O estoque deve ser feito em local fechado, coberto e apropriado para evitar a ação da água. Preferencialmente, deve estar em local próximo ao de uso ou de transporte vertical.

As chapas devem ser empilhadas na posição horizontal sobre três vigas de madeira, posicionados no centro da chapa e a cada $10 \mathrm{~cm}$ de cada uma das bordas, evitando-se contato com o piso. No caso de armazenamento em lajes, verificar sua capacidade de resistência para evitar sobrecarga. Em lajes usuais (de edifícios residenciais e comerciais), a pilha não deve exceder a $40 \mathrm{~cm}$ de altura.

Também é recomendável que a data de entrega e o local de estocagem sejam planejados com antecedência, de modo a evitar a pré-estocagem em locais inadequados, interferência com outros serviços da obra ou a necessidade de transporte horizontal interno.

Do pedido de compra devem constar:

- Fatores geométricos (número e espessura das lâminas e composição);

- Tipo de chapa (resinada ou plastificada) e dimensões desejadas pela obra;

- Número da norma pertinente - NBR 9531(1985) e NBR 9532 (1986);

- Número mínimo de reaproveitamentos da fôrma garantido pelo fabricante; 
- Aviso esclarecendo que as chapas de madeira compensada não devem apresentar defeitos sistemáticos, tais como desvios dimensionais, desvios no esquadro, número de lâminas inadequado à sua espessura, defeitos superficiais ou defeitos nas bordas;

- Aviso esclarecendo que as chapas que não atenderem às especificações serão devolvidas;

- Aviso esclarecendo que a partida será aceita com a observação de que na obra haverá checagem do lote quanto à resistência à água, podendo este ser rejeitado num prazo de 48 horas em caso de reprovação no teste.

\subsection{Cuidados no corte das chapas de madeira compensada}

Nem sempre se utilizam fôrmas industrializadas, seja por motivo de custo ou ainda por peculiaridades da estrutura ou peça que se vai construir, ainda que alguns componentes tenham aquela origem.

Então, além das ferramentas manuais são também usadas máquinas, que devem contribuir para reduzir o esforço humano, agilizando os trabalhos e dando melhor acabamento às fôrmas e consequentemente ao concreto. No entanto, não raro, tais elementos são mal empregados, pois apenas são deixados nas mãos dos carpinteiros, dos quais poucos têm formação ou discernimento para operá-los com melhor rendimento. Cabe aos técnicos e dirigentes das obras orientá-los, quer na escolha ou na maneira de usar as máquinas.

A serra circular é uma máquina que, em geral, não se usa adequadamente em obras de construção civil. A definição da bancada, por exemplo, deve-se basear na maior dimensão da peça a ser cortada no canteiro. Sempre construída com tábuas, formando uma superfície irregular, ou com pedaço reduzido de chapa compensada mostra-se, geralmente, com dimensões insuficientes. Pode acontecer que a dimensão da chapa seja muito superior à da mesa, fazendo a placa tender a desequilibrar para fora da bancada, como conseqüência o mais provável é que o corte seja sinuoso.

Outro problema da serra circular é o tipo dos dentes adequados aos acabamentos que se pretende. É necessário atentar para o fato de que dentes maiores, com passos maiores, geram superfícies mais ásperas. Para cortar barrotes de $7,5 \mathrm{~cm} \times 7,5 \mathrm{~cm}$ utiliza-se o disco de serra do tipo mostrado na FIGURA 2.5a, pois a superfície resultante não necessita de um fino acabamento. Entretanto, 
ao cortar chapas de madeira compensada o resultado será pouco recomendável, dilacerando, de forma inconveniente, os bordos das chapas. Logo, nesse último caso não se pode esperar bons cortes com dentes do tipo da FIGURA 2.5a, esquematizado em seguida, sendo o da FIGURA 2.5b mais adequado.

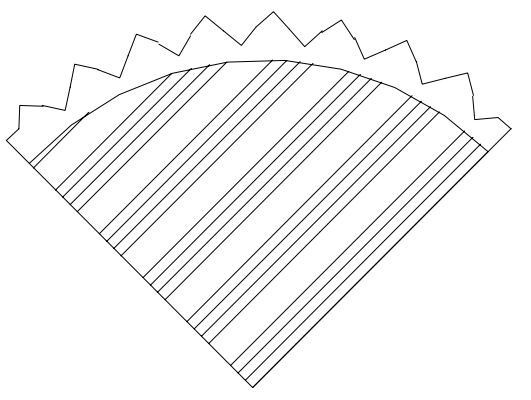

(a)

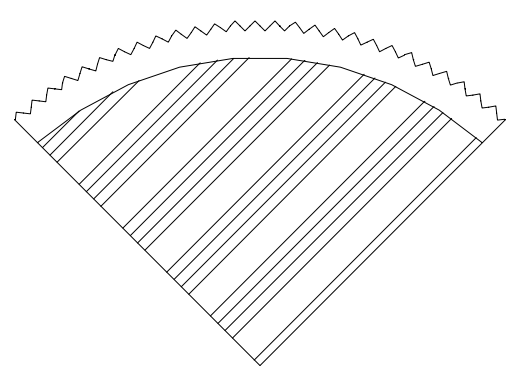

(b)

FIGURA 2.5 - Tipos de serras quanto ao tamanho dos dentes

Nas chapas de madeira compensada, para se conseguir um corte perfeito deve-se empregar serra de vídia com dentes menores. Na TABELA 2.4, em seguida, discriminam-se os tipos de serras mais recomendadas para cada tipo de máquina.

TABELA 2.4 - Sugestões para tipos de serras

\begin{tabular}{c|c|c|c}
\hline $\begin{array}{c}\text { Diâmetro } \\
(\mathbf{m m})\end{array}$ & $\begin{array}{c}\text { Espessura do } \\
\text { disco }(\mathbf{m m})\end{array}$ & $\begin{array}{c}\text { Diâmetro interno } \\
\text { da fixação } \mathbf{( m m})\end{array}$ & $\begin{array}{c}\text { Números de } \\
\text { dentes }\end{array}$ \\
\hline $\begin{array}{c}300 \\
\text { (máquinas fixas) }\end{array}$ & 3 & 30 & 56 \\
\hline $\begin{array}{c}350 \\
\text { (máquinas móveis) }\end{array}$ & 3,5 & 30 & 60 \\
\hline
\end{tabular}

Outra advertência refere-se ao corte sem auxílio de guias ou esquadros. Acreditando-se que mesmo havendo habilíssimos carpinteiros, deve-se observar que, sem o apoio de guias ou esquadros, as chapas, que têm grandes dimensões, terão recortes sinuosos, as quais, acabam sendo origens de fuga de nata de cimento das fôrmas, gerando cavernas (chamadas de bexigas ou bicheiras). 


\subsection{Desmoldantes para chapas de madeira compensada}

Os desmoldantes são substâncias que formam uma fina camada oleosa entre o concreto e as fôrmas, impedindo a aderência entre ambos, o que facilita a remoção das fôrmas, sem danificar as superfícies e arestas do concreto. Os desmoldantes são compostos por ácidos graxos e ésteres, alguns possuindo hidrocarbonetos na sua composição.

A barreira química criada pelo desmoldante deve ser resistente à água, reduzindo a penetração de umidade nas chapas de madeira compensada, com um significativo aumento da durabilidade das fôrmas. Deve ser evitada a utilização de óleos e graxas como desmoldante, estes além de não impedirem a aderência entre as fôrmas e o concreto, deixam seus resíduos no concreto, o que dificulta a aplicação dos revestimentos (reboco, pintura, cerâmica, etc.), e no caso do concreto aparente deixa-o com uma aparência desagradável.

A aplicação dos desmoldantes sobre as fôrmas devem ser feitas com broxas ou escovões de maneira uniforme. Após secar uma hora, pode-se iniciar a concretagem. Sempre limpar e aplicar o desmoldante às fôrmas, antes de cada reaproveitamento. Em caso de dúvidas, respeitar as especificações para a aplicação do produto, de acordo com o fabricante.

\subsection{Considerações finais}

Sem dúvidas nenhuma a chapa de madeira compensada é o material mais utilizado como molde para as fôrmas de concreto. Entretanto, é de primordial importância que esses painéis possam ser reaproveitados o maior número de vezes possível, bem como sejam devidamente especificados para a sua utilização. Para isso torna-se necessário o seu conhecimento, e que as responsabilidades da compra partam dos setores técnicos da empresa, e não financeiro. 


\section{AÇÕES NAS FÔRMAS}

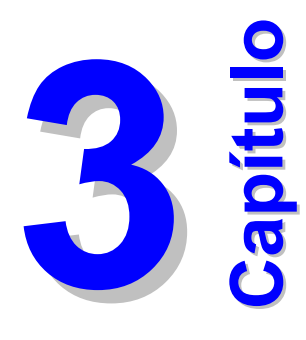

\subsection{Generalidades}

Neste tópico serão estudadas as ações a que estão sujeitos os sistemas de fôrmas, auxiliando os projetistas na definição dos carregamentos, fundamentando o projeto de fôrmas para as condições usuais aplicáveis ao concreto armado. Tornase pois, importante, uma definição coerente das ações a que estão submetidas as fôrmas para a elaboração do projeto.

As fôrmas estão sujeitas a sobrecargas de operação, lançamento e adensamento do concreto durante a moldagem da estrutura. Devem ser consideradas situações como colocação assimétrica do concreto, as ações permanentes e variáveis, as cargas devidas à pressão lateral exercida pelo concreto, as cargas horizontais devidas à ação do vento e à movimentação de equipamentos de construção, bem como ações excepcionais que possam vir a acontecer. 


\subsection{Ações permanentes}

Ações permanentes são as que ocorrem com valores constantes ou de pequena variabilidade em torno de sua média ao longo do funcionamento ou da vida útil da estrutura. Estas englobam o peso próprio das fôrmas e o peso do concreto fresco mais o da armadura. Geralmente o peso próprio das fôrmas mostrase pequeno quando comparado ao carregamento total vertical, sendo na maioria das vezes negligenciado pelos projetistas. Na TABELA 3.1 estão mostrados os materiais comumente usados para fôrmas com seus respectivos pesos específicos.

TABELA 3.1 - Pesos específicos dos materiais comumente utilizados nas fôrmas

\begin{tabular}{c|c|c}
\hline Material & $\begin{array}{c}\text { Peso Específico } \\
\mathbf{( k N / \mathbf { m } ^ { 3 } )}\end{array}$ & $\begin{array}{c}\text { Peso por } \mathbf{~ c m ~ d e ~} \\
\text { espessura }\left(\mathbf{k N} / \mathbf{m}^{\mathbf{2}}\right)\end{array}$ \\
\hline Chapas de Madeira Compensada & $5,0-7,0$ & $0,05-0,07$ \\
\hline Madeira & $5,0-12,2$ & $0,05-0,122$ \\
\hline Aço & 78,5 & 0,785 \\
\hline Alumínio & 27,7 & 0,277 \\
\hline
\end{tabular}

Como existem várias opções na escolha do sistema de fôrmas, o modo mais correto de avaliar o peso das fôrmas é, sem dúvida, a elaboração de um anteprojeto.

Para o caso de um sistema de fôrmas misto, mesclando o uso de chapas de madeira compensada com madeira e aço, a carga para o peso próprio pode variar entre $0,40 \mathrm{kN} / \mathrm{m}^{2}$ e $0,60 \mathrm{kN} / \mathrm{m}^{2}$, sendo necessário verificar estes valores para cada caso específico.

No caso de pilares, paredes e vigas com faces alinhadas verticalmente, a análise deve incluir a pressão exercida pelo concreto fresco (assunto tratado de maneira mais criteriosa no item 3.5), ficando pois, desnecessária a consideração do peso próprio das fôrmas, bem como da ação do peso próprio do concreto e de possíveis ações variáveis. Isto não ocorre quando estas faces estão alinhadas de modo não vertical (inclinada). A FIGURA 3.1, em seguida, ilustra melhor o caso. 


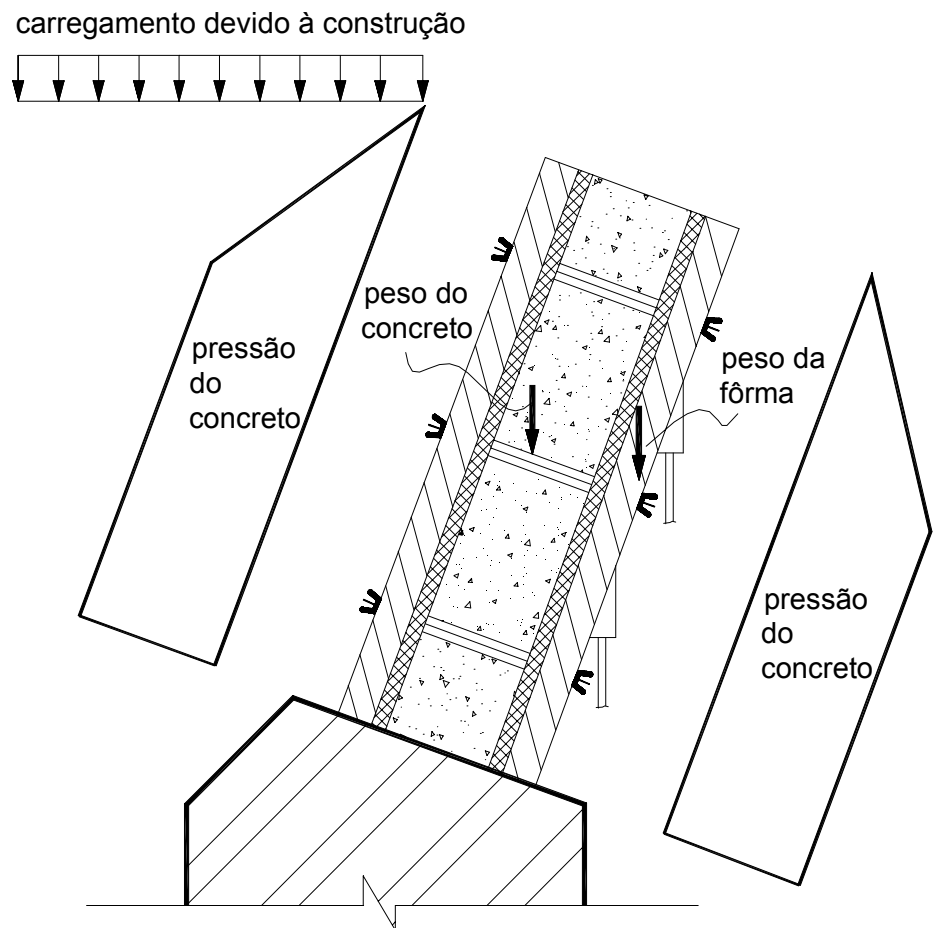

FIGURA 3.1 - Fôrma de um pilar inclinado com seus possíveis modos de carregamento

Quanto à carga imposta pelo concreto fresco com a armadura, pode-se considerar um peso específico de $25 \mathrm{kN} / \mathrm{m}^{3}$ (estimado com taxa de armadura igual a $2 \%$, em volume), sendo o peso por centímetro de espessura igual a $0,25 \mathrm{kN} / \mathrm{m}^{2}$. Se forem utilizados concretos que se afastam muito deste valor, torna-se necessária uma reavaliação do peso específico. É o caso, por exemplo, dos concretos com agregados leves ou particularmente densos.

\subsection{Ações variáveis}

As ações variáveis são as que ocorrem com valores que apresentam variações significativas em torno de sua média ao longo do funcionamento ou da vida útil da estrutura. Algumas ações variáveis que podem ser consideradas no projeto de fôrmas são: o peso dos trabalhadores que trafegam sobre o assoalho; equipamentos necessários para auxiliar na concretagem, tais como vibradores, gericas, carrinhos de mão, etc; materiais e o impacto produzido pelo lançamento e adensamento do concreto. 
Vários são os valores encontrados na literatura, pois os mesmos são susceptíveis de distintas interpretações pelos projetistas. Relacionam-se, a seguir, propostas de algumas normas e estudiosos, para as ações variáveis.

\subsubsection{American Concrete Institute - ACI 347R/88}

O Comitê 347R (1988) do $\mathrm{ACl}$, muito conservativo, estabelece que as fôrmas devem ser projetadas para um valor mínimo das ações variáveis igual a $2,44 \mathrm{kN} / \mathrm{m}^{2}$. No caso da utilização de carros motorizados para o lançamento do concreto este valor é aumentado, passando a $3,66 \mathrm{kN} / \mathrm{m}^{2}$.

O Comitê 347R também prescreve que a carga mínima de projeto, combinando-se as ações permanentes e variáveis, deve ser $4,88 \mathrm{kN} / \mathrm{m}^{2}$, ou 6,10 $\mathrm{kN} / \mathrm{m}^{2}$ quando são utilizados carros motorizados para o lançamento do concreto.

\subsubsection{Bristish Standards Institution - BS 5975/95}

A BS 5975 (1995) da BSI adota para as ações variáveis a serem consideradas no projeto de fôrmas o valor de $1,5 \mathrm{kN} / \mathrm{m}^{2}$. Quando o tráfego sobre o assoalho for utilizado apenas para a inspeção, as ações acidentais podem ser reduzidas para $0,75 \mathrm{kN} / \mathrm{m}^{2}$.

A BS 5975 atenta para fato de um possível acúmulo de concreto em um determinado local no lançamento do mesmo, pois o valor de $1,5 \mathrm{kN} / \mathrm{m}^{2}$ representa somente $6 \mathrm{~cm}$ de concreto extra, o que trará efeitos mais significantes em lajes delgadas do que em lajes espessas. Este tema será melhor detalhado no item 3.7.

\subsubsection{Eng ${ }^{\circ}$. João Alberto Venegas REQUENA}

REQUENA (1983) recomenda para as ações variáveis a serem consideradas no projeto de fôrmas a parcela de $10 \%$ do peso próprio do concreto armado.

Por exemplo, para uma laje de um pavimento de um edifício residencial com uma espessura de $10 \mathrm{~cm}$, ter-se-ia o valor de $0,25 \mathrm{kN} / \mathrm{m}^{2}$ como ação variável, sendo a carga total vertical a ser considerada a soma do peso próprio do concreto 
$\left(2,5 \mathrm{kN} / \mathrm{m}^{2}\right)$ com o valor da ação acidental dada anteriormente mais a consideração do peso próprio do sistema de fôrmas.

\subsubsection{Associação Brasileira de Cimento Portland - ABCP}

A ABCP (1944) através do Boletim BT-50, atualmente em fase de revisão, estabelece que a sobrecarga que deve ser considerada no cálculo das fôrmas, resultante do peso dos carrinhos de material e dos operários que circulam sobre elas, durante a concretagem, deve ser igual a $1,00 \mathrm{kN} / \mathrm{m}^{2}$, valor este menos conservativo quando comparado aos outros documentos normativos.

No entanto, a ABCP observa que a sobrecarga dos carrinhos de duas rodas (gericas), de uso cada vez mais freqüente, possuem peso próprio de cerca de 0,50 $\mathrm{kN}$ e capacidade média de $1,20 \mathrm{kN}$ de concreto, excedendo o valor adotado. Ainda, segundo a $A B C P$, torna-se desnecessário ir além do limite fixado, por se tratar de carga não permanente e considerando também o fator de segurança adotado nos cálculos subseqüentes.

\subsubsection{Comite Euro-International du Beton - CEB}

O Boletim n. 115 do CEB (1976) estabelece para as ações variáveis devidas aos trabalhadores, equipamentos, armazenamento de materiais, efeitos dinâmicos e outras, um valor que pode variar entre $1,50 \mathrm{kN} / \mathrm{m}^{2}$ e $3,50 \mathrm{kN} / \mathrm{m}^{2}$, de acordo com as circunstâncias. Fica a critério do projetista de fôrmas a adoção do valor mais apropriado para a situação em questão.

\subsubsection{Avaliação das propostas sobre ações variáveis}

Através das propostas apresentadas anteriormente, percebe-se que os valores são muito díspares. Com o intutito de se avaliar as várias referências citadas, tem-se como exemplo hipotético uma laje de $10 \mathrm{~cm}$ a ser concretada. $O$ concreto será usinado e lançado através de bobeamento com a utilização de gericas, com condições normais e usuais. Para o caso específico do exemplo em estudo cada uma das propostas forneceria para as ações variáveis o valor de: 
- $\quad \mathrm{ACl} 347 \mathrm{R} / 88$

- $\quad$ BS 5975/95

- REQUENA (1983)

- $\quad$ ABCP (1944)

- CEB (1976)

$\begin{array}{rr}2,44 & \mathrm{kN} / \mathrm{m}^{2} \\ 1,50 & \mathrm{kN} / \mathrm{m}^{2} \\ 0,25 & \mathrm{kN} / \mathrm{m}^{2} \\ 1,00 & \mathrm{kN} / \mathrm{m}^{2} \\ \text { entre } 1,50 \text { e } 3,50 & \mathrm{kN} / \mathrm{m}^{2}\end{array}$

Verifica-se uma diferença de $1300 \%$ entre o valor inferior $\left(0,25 \mathrm{kN} / \mathrm{m}^{2}\right)$ e o maior possível $\left(3,50 \mathrm{kN} / \mathrm{m}^{2}\right)$. Esta diversidade tão grande de recomendações justifica que a análise crítica do projetista em cada caso deve ser valorizada. Deve ser considerado que a fôrma é uma estrutura provisória; que as cargas acidentais são transitórias, não permanecendo estáticas sobre o mesmo ponto; e ainda que dificilmente se terá atuando concomitamente a ação variável máxima e o peso do concreto armado numa certa região.

Não deve ser esquecido que os coeficientes de segurança podem cobrir uma boa margem de erros para estes valores. Diante da experiência brasileira em fôrmas, como ação variável, para casos comuns e usuais, pode ser recomendado o valor de $1,00 \mathrm{kN} / \mathrm{m}^{2}$.

É bom deixar claro que este valor adotado não deve ser generalizado, devendo ser analisados os casos particulares (grande fluxo de trabalhadores, utilização de pesados equipamentos, etc.).

\subsection{Ações verticais no assoalho de fundo das vigas}

Todas as considerações sobre ações variáveis feitas anteriormente referemse aos assoalhos de laje. Quando se trata do assoalho do fundo das vigas a ação vertical a ser considerada será a ação permanente, devida ao peso do concreto, com peso específico de $25 \mathrm{kN} / \mathrm{m}^{3}$, acrescida de $0,50 \mathrm{kN} / \mathrm{m}^{2}$ devidos ao peso próprio das fôrmas e a vibração e $0,50 \mathrm{kN} / \mathrm{m}^{2}$ para as ações variáveis. Isso garantirá uma avaliação satisfatória, já que o assoalho de fundo das vigas dificilmente estará sujeito a ações de trabalhadores, equipamentos ou outras ações. Este procedimento não deve, porém, ser generalizado, devendo ser analisados os casos particulares. 


\subsection{Ações devidas às pressões laterais exercidas pelo concreto nas faces das fôrmas}

As pesquisas que avaliam as pressões laterais nas fôrmas para concreto armado têm sido desenvolvidas, principalmente no âmbito internacional, porém não se tem chegado a resultados em comum.

Segundo CRUZ (1997), no Brasil, as pesquisas relacionadas a fôrmas são bastante recentes (10 anos), e poucas abordam, especificamente, a determinação de pressões laterais exercidas pelo concreto fresco.

As fôrmas têm o objetivo de dar ao concreto armado em sua etapa construtiva a geometria estipulada no projeto, até que o mesmo adquira suficiente resistência. Até que essa se desenvolva o concreto é contido pelas laterais das fôrmas, que impedem seu abatimento sobre o plano inferior.

\subsubsection{Comportamento do concreto fresco nas fôrmas}

GARDNER et al. (1981) apud CRUZ (1997), relatam que o concreto fresco pode ser visualizado como partículas de agregados inertes, as quais são suspensas numa matriz deformável de pasta de cimento e bolhas de ar. Dado o tempo e as condições próprias do ambiente, a pasta de cimento é convertida, através de um processo físico-químico entre os grãos de cimento e água, numa massa homogênea de partículas.

O concreto fresco, sendo um sistema composto de partículas fragilmente interligadas e submergidas em meio fluido, possui resistência cisalhante resultante do atrito entre as partículas que o constituem, bem como entre elas e as superfícies da fôrma e da armadura. Essas forças podem ser denominadas atrito interno e atrito superficial, respectivamente.

Quando o concreto é lançado na fôrma provoca um choque nas mesmas, em seguida realiza-se um adensamento, manual ou mecânico. $O$ processo do adensameto feito por vibração, interna ou externamente, consiste essencialmente na eliminação do ar aprisionado e na neutralização das forças de atrito interno e superficial.

Porém, ao se realizar o adensamento, esse repouso é pertubado por uma fluidificação da mistura, que passará a se comportar de modo semelhante a um 
líqüido, tendo como caso extremo a pressão lateral caracterizada como hidrostática $\left(Q_{c, \text { máx }}=\gamma_{\mathrm{c}} \cdot \mathrm{h}\right)$. Em planos onde a seção transversal é pequena, o vibrador pode aplicar nas fôrmas uma energia relativamente alta. A profundidade do efeito do vibrador aumenta com a vibração conjunta da fôrma, trazendo como conseqüência um aumento na pressão do concreto.

\subsubsection{Considerações sobre as pressões laterais do concreto}

Estudos e ensaios foram realizados para determinar uma expressão adequada para a estimativa da pressão lateral que o concreto exerce sobre as fôrmas, mas os resultados obtidos têm diferido bastante em função das muitas variáveis que afetam o problema. A pressão lateral exercida pelo concreto sobre as fôrmas depende de diversos fatores, e isto conduz a uma indefinição no que concerne aos valores a serem adotados na elaboração de projetos. Segundo CALIL JR. et al. (1998) e o Comitê 622 do ACl (1958) os principais fatores que influenciam são:

- velocidade de lançamento do concreto;

- temperatura do concreto;

- dosagem do concreto;

- consistência do concreto;

- energia de adensamento;

- impacto de lançamento;

- dimensões das fôrmas;

- quantidades e distribuição das armaduras;

- peso específico do concreto;

- altura da camada do concreto fresco;

- dimensões dos agregados;

- temperatura ambiente;

- textura e permeabilidade dos painéis;

- uso de aditivos;

- deformabilidade das fôrmas;

- o aglomerante - sua natureza, dosagem e tempo de pega.

CALIL JR. et al. (1998), através da TABELA 3.2, apresentou uma análise qualitativa da influência de alguns desses fatores na pressão exercida pelo concreto. 
TABELA 3.2 - Fatores que influenciam na pressão lateral do concreto [Fonte: CALIL JR. et al. (1998)]

\begin{tabular}{l|l}
\hline \multicolumn{1}{c|}{ Fator } & Influência \\
\hline Velocidade de Concretagem & Pressão \\
\hline Temperatura & Pressão \\
\hline Dosagem do Concreto & Pressão \\
\hline Consistência do Concreto & Pressão \\
\hline Energia de Adensamento & Pressão \\
\hline Impacto de Lançamento & Pressão \\
\hline Dimensões das Fôrmas & Pressão \\
\hline Densidade de Armadura
\end{tabular}

Segundo os estudos realizados no Laboratório de Madeiras e de Estruturas de Madeira - LaMEM, do Departamento de Engenharia de Estruturas da Escola de Engenharia de São Carlos - USP, os fatores que têm influenciado mais sensivelmente as pressões laterais do concreto são a velocidade de concretagem e a consistência do concreto (SLUMP). Se a velocidade é grande, a pressão lateral sobre a fôrma será máxima; e se baixa, as primeiras porções de concreto lançado poderão desenvolver resistência cisalhante, ou seja, poderão estar com a pega iniciada, dentro de um certo tempo, o que reduz o valor da pressão do concreto.

A FIGURA 3.2 representa o enchimento de uma parede ou coluna. Observase o concreto desenvolvendo alguma resistência cisalhante, o que faz com que a pressão lateral seja hidrostática a partir da superfície livre, alcançando um valor máximo e então decrescendo [GARDNER (1985)]. 

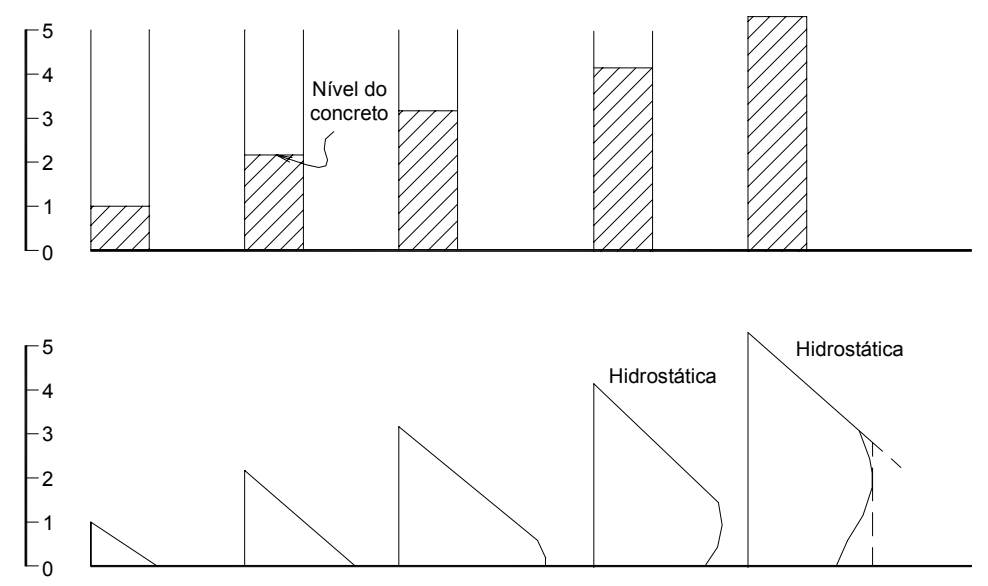

FIGURA 3.2 - Desenvolvimento da envoltória da pressão lateral do concreto [Adaptado: GARDNER (1985)]

Após o desenvolvimento de vários ensaios experimentais, HARRINSON \& CLEAR (1985) publicaram um estudo avaliando as pressões do concreto nas faces laterais das fôrmas. Em seguida a FIGURA 3.3 mostra o diagrama de pressões do concreto, resultado deste estudo, a ser considerado no cálculo, destacando-se a provável distribuição efetiva de pressões.

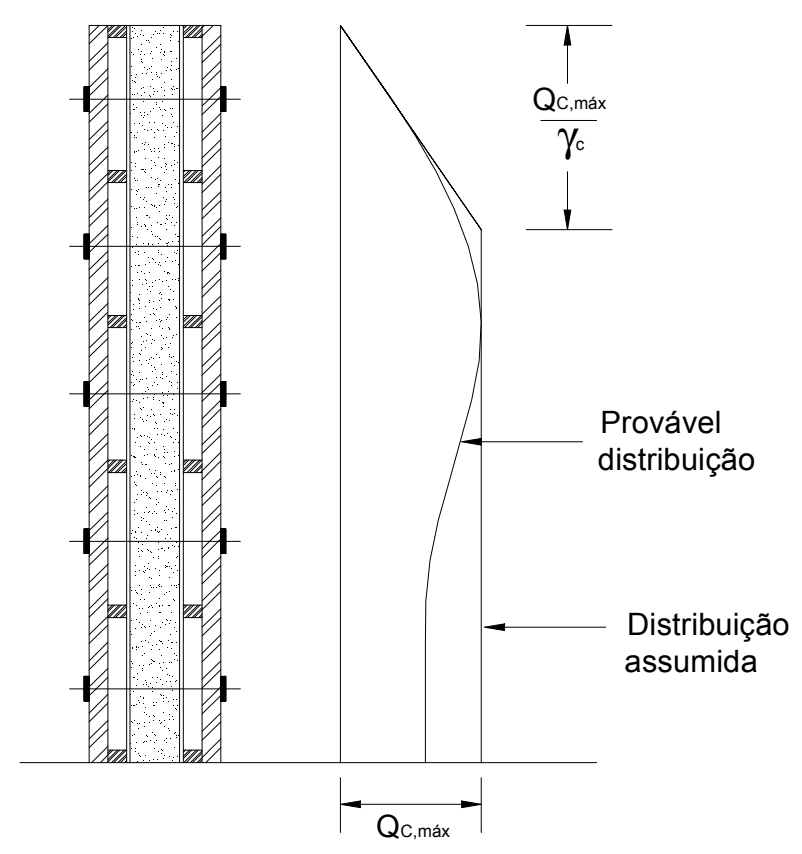

(a)

(b)

FIGURA 3.3 - Pressão do concreto nas faces laterais da fôrma: (a) corte e (b) diagrama de pressões 
Percebe-se que a pressão lateral é hidrostática a partir da superfície livre, alcança o máximo e então decresce, devido ao desenvolvimento de resistências cisalhantes, já comentadas, reduzindo a carga efetiva e diminuindo a pressão lateral para valores inferiores ao da pressão hidrostática.

\subsubsection{Cálculo das pressões laterais nas fôrmas para pilares}

O cálculo da pressão lateral que o concreto exerce nas faces laterais das fôrmas envolve muitas variáveis complexas. Alguns dos diversos métodos existentes para sua estimativa serão descritos em seguida. Trata-se dos mais difundidos no meio técnico, todos calcados em pesquisas experimentais, com suas respectivas formulações.

\section{a) Método do Comite Euro-International du Beton - CEB}

O método indicado no Boletim $\mathrm{n}^{\circ}$. 115 do CEB (1976) é aplicado para concretos fabricados com cimento portland, sem o emprego de aditivos. O peso específico considerado para o concreto é de $\gamma_{c}=24 \mathrm{kN} / \mathrm{m}^{3}$. Porém, se o peso específico diferir sensivelmente desse valor, o resultado obtido deverá ser multiplicado pela relação entre o novo peso específico e o valor estabelecido $\left(\gamma_{c}=\right.$ $24 \mathrm{kN} / \mathrm{m}^{3}$ ). No caso da altura de lançamento do concreto ser 2 metros ou maior, o valor da pressão encontrada deve ser aumentada de $10 \mathrm{kN} / \mathrm{m}^{2}$. O método foi baseado em investigações experimentais feitas em 200 construções. Segundo o CEB (1976), os fatores que mais influenciam na pressão são: peso específico do concreto; abatimento do concreto; temperatura do concreto; menor dimensão da seção; altura da camada de concreto fresco e a velocidade de concretagem.

A pressão a consideradar no projeto será a menor entre as obtidas pelas expressões seguintes:

- Pressão hidrostática (pressão do concreto fresco como fluido):

$\mathrm{Q}_{\mathrm{C}, \mathrm{h}}=24 \cdot \mathrm{h}$

$\left(\mathrm{kN} / \mathrm{m}^{2}\right)$

- Limite de endurecimento: 
$\mathrm{Q}_{\mathrm{C}, \mathrm{s}}=24 \cdot \mathrm{R} \cdot \mathrm{K}+5$

$\left(\mathrm{kN} / \mathrm{m}^{2}\right)$

onde $\mathrm{K}$ é um fator que depende do abatimento do concreto e de sua temperatura, como indicado na TABELA 3.3, mostrada a seguir.

TABELA 3.3 - Valores do fator K [Fonte: CEB (1976)]

\begin{tabular}{c|c|c|c|c|c|c}
\hline \multirow{2}{*}{ Abatimento $(\mathbf{m m})$} & \multicolumn{7}{|c}{ Temperatura do concreto $\left(^{\circ} \mathbf{C}\right)$} \\
\cline { 2 - 7 } & $\mathbf{5}$ & $\mathbf{1 0}$ & $\mathbf{1 5}$ & $\mathbf{2 0}$ & $\mathbf{2 5}$ & $\mathbf{3 0}$ \\
\hline 25 & 1,45 & 1,10 & 0,80 & 0,60 & 0,45 & 0,35 \\
\hline 50 & 1,90 & 1,45 & 1,10 & 0,80 & 0,60 & 0,45 \\
\hline 75 & 2,35 & 1,80 & 1,35 & 1,00 & 0,75 & 0,55 \\
\hline 100 & 2,75 & 2,10 & 1,60 & 1,15 & 0,90 & 0,65 \\
\hline
\end{tabular}

Se a menor dimensão (b) da seção de concreto é de $500 \mathrm{~mm}$ ou menos, uma terceira expressão será usada para calcular o efeito arco, isto é, as camadas verticais laterais passam a suportar zonas arqueadas que deixam de colaborar para o crescimento da pressão abaixo desse nível.

- Efeito arco:

$Q_{C, a}=3 \cdot R+\frac{b}{10}+15$

onde:

$R \quad$ é a velocidade de enchimento $(\mathrm{m} / \mathrm{h})$;

h é a altura da peça a ser concretada $(\mathrm{m})$;

b é a menor dimensão da seção de concreto $(\mathrm{mm})$.

A pressão, a ser considerada, será a menor entre as três vindas das expressões anteriores.

\section{b) Método do American Concrete Institute - ACI 347R/88}

O Comitê 347R do ACl (1988) coletou e analisou a literatura então existente, e propôs que, para o projeto de fôrmas com a profundidade de imersão do vibrador menor do que $1,25 \mathrm{~m}$ e o concreto com abatimento menor que $100 \mathrm{~mm}$, a envoltória 
da pressão deve ser hidrostática a partir da superfície livre do concreto na fôrma até um valor limite dado pelas equações seguintes, e então constante neste valor limite.

- Para paredes com R (velocidade de enchimento) $<2 \mathrm{~m} / \mathrm{h}$ :

$\mathrm{Q}_{\mathrm{C}}=7,2+\frac{785 \cdot \mathrm{R}}{\mathrm{T}+17,8}$

$\left(\mathrm{kN} / \mathrm{m}^{2}\right)$

com o máximo de $95,8 \mathrm{kN} / \mathrm{m}^{2}$, um mínimo de $28,7 \mathrm{kN} / \mathrm{m}^{2}$, mas não deve ultrapassar 23,5.h (pressão hidrostática).

- Para paredes com $2<\mathrm{R}<3 \mathrm{~m} / \mathrm{h}$ :

$Q_{C}=7,2+\frac{1156}{T+17,8}+\frac{244 \cdot R}{T+17,8}$

com o máximo de $95,8 \mathrm{kN} / \mathrm{m}^{2}$, um mínimo de $28,7 \mathrm{kN} / \mathrm{m}^{2}$, mas não deve ultrapassar 23,5.h (pressão hidrostática).

- Para paredes com $\mathrm{R}>3 \mathrm{~m} / \mathrm{h}$ :

$Q_{C, h}=23,5 \cdot h$

$\left(\mathrm{kN} / \mathrm{m}^{2}\right)$

com o máximo de $95,8 \mathrm{kN} / \mathrm{m}^{2}$.

- Para colunas:

$\mathrm{Q}_{\mathrm{C}}=7,2+\frac{785 \cdot \mathrm{R}}{\mathrm{T}+17,8}$

$\left(\mathrm{kN} / \mathrm{m}^{2}\right)$

com o máximo de $144 \mathrm{kN} / \mathrm{m}^{2}$, um mínimo de $28,7 \mathrm{kN} / \mathrm{m}^{2}$, mas não deve ultrapassar 23,5.h (pressão hidrostática), sendo $\mathrm{T}$ a temperatura do concreto $\left({ }^{\circ} \mathrm{C}\right)$ e $\mathrm{h}$ a altura da peça a ser concretada $(m)$.

\section{c) Método da Deutsches Institut Für Normung - DIN 18218/80}

A DIN 18218 (1980) apud GARDNER (1985), apresenta uma série de equações para calcular as pressões laterais dos mais variados tipos de concretos internamente vibrados, com temperatura de $15^{\circ} \mathrm{C}$. 
- Concreto com mistura densa:

$Q_{C}=21+5 \cdot R$

$\left(\mathrm{kN} / \mathrm{m}^{2}\right)$

- Concreto com mistura leve:

$Q_{C}=19+10 \cdot R$

$\left(\mathrm{kN} / \mathrm{m}^{2}\right)$

- Concreto com mistura fluida:

$Q_{C}=18+14 \cdot R$

$\left(\mathrm{kN} / \mathrm{m}^{2}\right)$

- Concreto com mistura muito fluida:

$Q_{C}=17+17 \cdot R$

$\left(\mathrm{kN} / \mathrm{m}^{2}\right)$

Onde R é a velocidade de enchimento $(\mathrm{m} / \mathrm{h})$.

Em seguida, na TABELA 3.4, está relacionada a consistência do concreto com o seu abatimento.

TABELA 3.4 - Valores do abatimento do concreto de acordo com sua consistência

\begin{tabular}{c|c}
\hline $\begin{array}{c}\text { Consistência do } \\
\text { Concreto }\end{array}$ & $\begin{array}{c}\text { Abatimento do } \\
\text { Concreto (mm) }\end{array}$ \\
\hline Mistura densa & 0 a 25 \\
\hline Mistura leve & 25 a 75 \\
\hline Mistura fluida & 75 a 125 \\
\hline Mistura muito fluida & Maior que 125 \\
\hline
\end{tabular}

A pressão não pode ser maior que a pressão hidrostática $\left(Q_{c, h}=24 . h\right)$. 


\section{d) Método de N. J. GARDNER}

Após diversos estudos e aperfeiçoamentos, GARDNER (1985) propôs uma expressão [EQUAÇÃO 3.12] para o cálculo das pressões laterais nas fôrmas. Esta expressão também pode ser usada para concreto de cimento com escórias ou resíduos finos.

$$
Q_{C}=24 h_{i}+\frac{b}{40}+\left(\frac{400 \sqrt{R}}{18+T}\right)\left(\frac{100}{100-\% F}\right)+\frac{S L U M P}{10} \quad\left(k N / m^{2}\right)
$$

A pressão não pode ser maior que a pressão hidrostática $\left(Q_{C, h}=24 . h\right)$.

Onde:

b é a menor dimensão das fôrmas $(\mathrm{mm})$;

$\mathrm{R} \quad$ é a velocidade de enchimento $(\mathrm{m} / \mathrm{h})$;

$\mathrm{T} \quad$ é a temperatura do concreto $\left({ }^{\circ} \mathrm{C}\right)$;

$\% \mathrm{~F} \quad$ é a porcentagem de resíduos finos ou escórias;

SLUMP é o abatimento do concreto $(\mathrm{mm})$;

$h_{i} \quad$ profundidade de imersão do vibrador $(m)$.

Segundo CRUZ (1997), o método desenvolvido por Gardner foi recomendado pela "Canadian Standards Association" CSA S269-M92.

\section{e) Método da teoria do empuxo de materiais sólidos e granulosos sobre as paredes dos silos}

Em 1895, Janssen apud RAVENET (1992) estabeleceu uma expressão para o cálculo de pressões nas paredes de silos. MOLITERNO (1989) apresentou a extrapolação desta formulação para as pressões exercidas pelo concreto nas fôrmas, considerando-se a pressão máxima para altura infinita. CALIL JR. et al. (1998) também propõem essa extrapolação.

$Q_{C}=\frac{A}{U} \frac{\gamma}{\operatorname{tg}\left(\varphi^{\prime}\right)}$

$\left(\mathrm{kN} / \mathrm{m}^{2}\right)$ 
Onde:
A é a área da seção transversal do pilar $\left(\mathrm{m}^{2}\right)$;
$\mathrm{U} \quad$ é o perímetro da área da seção transversal do pilar $(\mathrm{m})$;
$\gamma \quad$ é o peso específico do concreto $\left(24 \mathrm{kN} / \mathrm{m}^{3}\right)$;
$\varphi^{\prime} \quad$ é o ângulo de rugosidade entre o concreto e a parede da fôrma, igual a $0,75 \varphi$;
$\varphi$
é o ângulo de talude natural do concreto no estado plástico, sendo $15^{\circ}$ para o concreto muito plástico e $25^{\circ}$ para o concreto fresco.

A pressão não pode ser maior que a pressão hidrostática $\left(Q_{C, h}=24 . h\right)$.

\subsubsection{Cálculo das pressões laterais nas fôrmas para vigas}

Assim como nos pilares, a pressão lateral que o concreto exerce nas faces das fôrmas das vigas não varia linearmente com a altura. CALIL JR. et al. (1998) propõem a utilização das teorias clássicas de empuxo de terra, através do critério de ruptura de Mohr-Coulomb, detalhada posteriormente para o caso de pilares (ver item 4.7). A FIGURA 3.4 ilustra o diagrama de pressões do concreto agindo sobre as fôrmas das vigas.

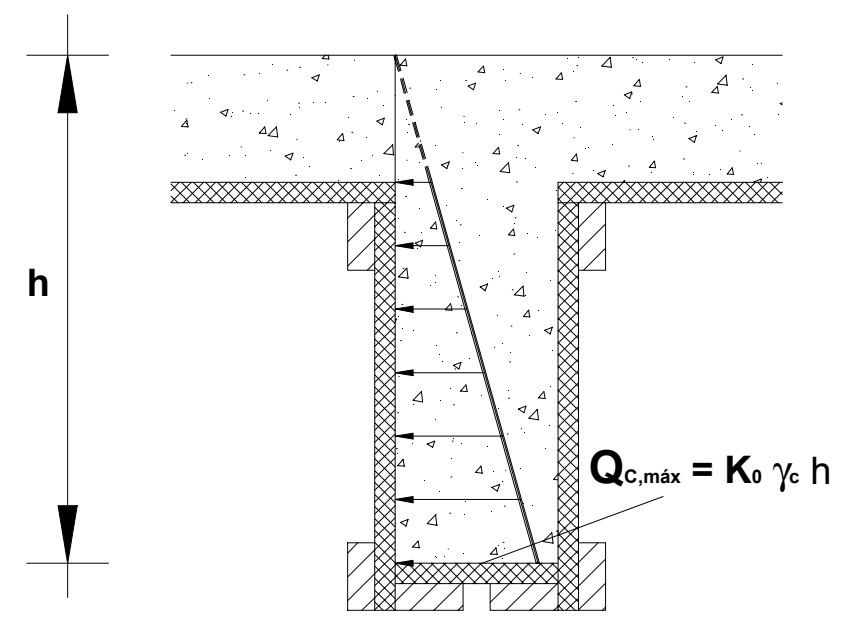

FIGURA 3.4 - Diagrama de pressões nas fôrmas para vigas 


\subsection{Ações horizontais}

As fôrmas devem ser projetadas para suportarem as ações horizontais previsíveis, como a ação do vento, os impactos do bombeamento do concreto ou da movimentação de equipamentos (gericas, carrinhos de mão ou carros motorizados). $\mathrm{Na}$ ausência de uma consideração mais precisa sobre o carregamento horizontal que atuará, o Comitê 347R do ACI (1988) prescreve valores mínimos para o cálculo do travamento lateral das fôrmas, sendo o maior dos seguintes valores: 1,46 kN/m atuando na extremidade da laje, em todo o seu contorno, ou $2 \%$ da carga permanente total, distribuída como uma carga uniforme por metro linear de extremidade de laje, a FIGURA 3.5 ilustra a situação de carregamento.



FIGURA 3.5 - Carregamento $\left(F_{h}\right)$ para cálculo do contraventamento do sistema de fôrmas [Fonte: HURD (1995)]

Para pilares ou paredes, o Comitê 347R também estabelece valores mínimos para a consideração da ação do vento, adotando o maior dos seguintes valores: 1,46 kN/m atuando no topo do pilar ou parede (ver FIGURA 3.6); ou 0,73 $\mathrm{kN} / \mathrm{m}^{2}$ como a pressão da ação do vento. No caso dos códigos normativos locais não estabelecerem valores, as situações que necessitarem da consideração da ação do vento, ou seja, casos atípicos de sistemas de fôrmas, devem estar de acordo com a NBR 6123 (1988) - Forças devidas ao vento em edificações, da ABNT. 


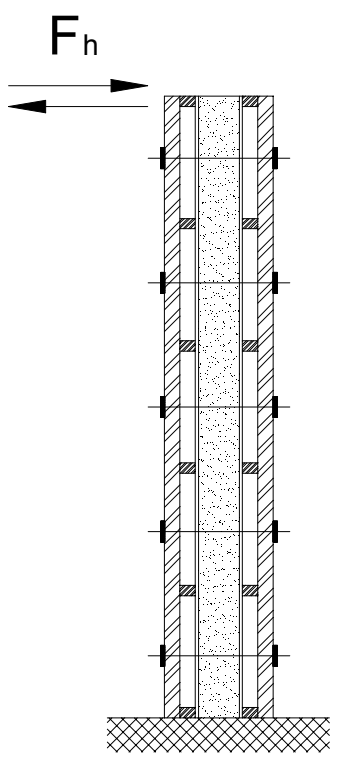

FIGURA 3.6 - Carregamento $\left(F_{h}\right)$ para cálculo do contraventamento do pilar [Fonte: HURD (1995)]

$\mathrm{Na}$ prática construtiva atualmente exercida no Brasil, principalmente em edificações, não é comum a utilização de equipamentos sobre as fôrmas, que produzam cargas laterais consideráveis, como o caso de carros motorizados. A ação horizontal mais importante torna-se, pois, a ação do vento, principalmente quando a fôrma ainda se encontra não preenchida pelo concreto. No Capítulo 6 Disposições construtivas serão abordados detalhes construtivos, ou seja, modos de contraventamento para os pilares e todo o sistema de fôrmas que garantirão o travamento lateral do sistema. Embora o efeito do vento não venha sendo levado em conta pelos projetistas de fôrmas, deixando-se apenas valer por detalhes construtivos, o importante é não generalizar esse procedimento, procurando analisar cada caso em questão.

\subsection{Outras ações}

Durante a construção de edifícios em concreto armado de múltiplos andares, os pavimentos recém-concretados são temporariamente sustentados por pavimentos inferiores através de um conjunto constituído de fôrmas, escoras e reescoras. Toda a ação construtiva, transmitida a um pavimento que pertença momentaneamente ao sistema de suporte, pode ultrapassar as ações em serviço para as quais vigas e lajes foram projetadas. O modo e o tempo de aplicação das 
ações construtivas dependem fundamentalmente do processo de construção adotado. Diante disto, torna-se importante definir a quantidade de lajes reescoradas de acordo com os prazos a serem adotados no processo construtivo, para que não ocorra uma combinação de ações elevadas com baixas resistências do concreto. Este assunto será tratado de maneira mais detalhada em capítulo à parte (Capítulo $6)$.

Uma anomalia que pode ocorrer em edifícios durante o período de construção observa-se quando os membros das fôrmas são contínuos apoiados sobre várias escoras, é comum na concretagem concentrar um grande volume de concreto fresco num determinado vão para posteriormente ser espalhado sobre o assoalho da fôrma, podendo causar uma tendência de levantar a fôrma nos outros apoios. Desta maneira, na etapa de projeto devem ser previstas maneiras de manter os membros unidos às escoras em tais condições. Não sendo isto possível, tais membros devem ser projetados e executados como simplesmente apoiados, a FIGURA 3.7 ilustra o problema.



FIGURA 3.7 - Concentração de um grande volume de concreto fresco num determinado vão, podendo ocasionar o levantamento da fôrma

Este acúmulo elevado de concreto em determinadas regiões, na fase de concretagem, solicita de modo não previsto o sistema de fôrma, podendo chegar a rupturas locais, ou até global, pelo fato de não ter sido previsto na fase de projeto. Falhas como essa vêem ocorrendo de maneira freqüente nas construções atuais. 
Se não for feita a previsão na fase de projeto, deve-se advertir para que tal procedimento não venha a ocorrer na execução.

Quando o problema não ocorre diretamente no sistema de apoio (cimbramento) do pavimento em concretagem, este pode vir a ocorrer em pavimentos inferiores, apoiados por um sistema de reescoramento, precipitando a ruína da escora, por esmagamento ou flambagem, ou ainda a punção da laje de tenra idade, ou mesmo desaprumo da escora por falta de ligação com o sistema, conforme a ilustração mostrada na FIGURA 3.8.

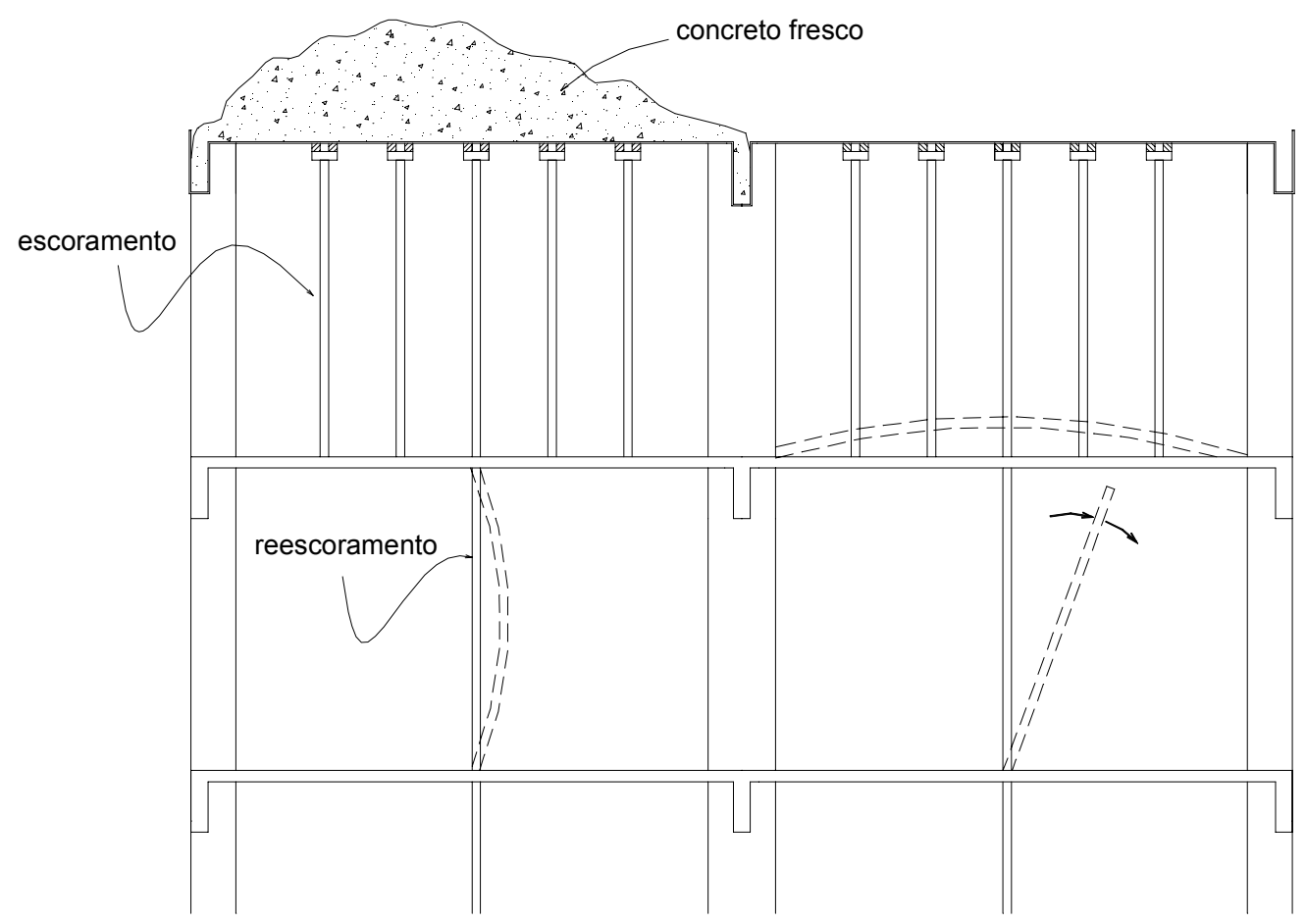

FIGURA 3.8 - Possíveis tipos de anomalias nos sistemas de fôrmas

As fôrmas devem ser projetadas para qualquer condição especial de ação ou construção que venha a acontecer, como armazenamento de materiais de construção não previstos, ou em operações de protensão em lajes protendidas "in loco", que podem gerar esforços além dos previstos, devendo ser devidamente considerados e acompanhados pelo projetista de fôrmas. 


\subsection{Combinações das ações}

Seguindo os critérios de dimensionamento da NBR 7190 (1997) - Projeto de estruturas de madeira, da ABNT, para a verificação da segurança em relação aos estados limites últimos é feita em função das combinações últimas normais, e a verificação da segurança em relação aos estados limites de utilização é feita em função das combinações de curta duração. As combinações e os coeficientes para o dimensionamento dos sistemas de fôrmas estão apresentados a seguir.

\subsubsection{Estados limites últimos}

Embora o sistema de fôrmas seja utilizado durante uma fase de construção da estrutura da edificação, o mesmo deve ser encarada como uma estrutura própria, ou seja, durante um certo tempo estará servindo de apoio para o concreto, entre outras ações já comentadas. Portanto a utilização das combinações últimas normais seria a mais coerente.

$$
F_{d}=\sum_{i=1}^{m} \gamma_{G i} F_{G i, k}+\gamma_{Q}\left[F_{Q 1, k}+\sum_{j=2}^{n} \psi_{0 j} F_{Q j, k}\right]
$$

onde $F_{G i, k}$ representa o valor característico das ações permanentes, $F_{Q 1, k} O$ valor característico da ação variável principal para a combinação considerada, no caso de haver várias ações variáveis atuando, e $\psi_{0 \mathrm{j}} \mathrm{F}_{\mathrm{Qj}, \mathrm{k}}$ os valores reduzidos de combinação das demais ações variáveis. O fator $\psi_{0 j}$ é igual a 0,7 , de acordo com a NBR 7190 (1997), considerando cargas acidentais dos edifícios e locais onde há predominância de pesos de equipamentos fixos, ou de elevadas concentrações de pessoas. O coeficiente de ponderação $\gamma_{G i}$ relativo às ações permanentes que figuram nas combinações últimas normais deve ser considerado igual a 1,4 , de acordo com a NBR 7190 (1997). O coeficiente de ponderação $\gamma_{Q}$ das ações variáveis que figuram nas combinações últimas normais também é tomado igual a 1,4, de acordo com a NBR 7190 (1997). 


\subsubsection{Estados limites de utilização}

As combinações de curta duração são utilizadas quando for importante impedir defeitos decorrentes das deformações da estrutura.

$$
F_{d, u t i}=\sum_{i=1}^{m} F_{G i, k}+F_{Q 1, k}+\sum_{j=2}^{n} \psi_{1 j} F_{a j, k}
$$

onde $F_{G i, k}$ representa o valor característico das ações permanentes, $F_{Q 1, k} O$ valor característico da ação variável principal para a combinação considerada, no caso de haver várias ações variáveis atuando, e $\psi_{1 j} F_{\mathrm{Qj}, \mathrm{k}}$ os valores reduzidos de combinação das demais ações variáveis. O fator $\psi_{1 j}$ é igual a 0,6, de acordo com a NBR 7190 (1997), considerando cargas acidentais dos edifícios e locais onde há predominância de pesos de equipamentos fixos, ou de elevadas concentrações de pessoas.

\subsection{Considerações finais}

As fôrmas são estruturas provisórias e servem para suportar o concreto no estado plástico. São, portanto, estruturas e como tal devem ser pensadas. Devem resistir aos esforços resultantes da atuação das mais diversas ações. Quaisquer que sejam as peças concretadas, estarão sempre sujeitas às ações.

A definição coerente das ações é parte indispensável para se obter segurança e economia no produto final do sistema de fôrmas.

A falta de um código normativo brasileiro pode gerar dúvidas na definição das ações. Torna-se pois importante, a experiência e bom senso por parte dos projetistas e profissionais ligados aos projetos de fôrmas. 


\subsection{Generalidades}

Com intuito de desenvolver a parte experimental deste trabalho de modo a que os resultados expressassem da maneira mais adequada possível o comportamento das fôrmas durante a concretagem, buscou-se a cooperação de algumas empresas construtoras de São Carlos. Foi firmado um acordo com a Construtora Bianco, a qual permitiu o acesso às suas obras. Foi, então, escolhido o Edifício Jatobá, para o desenvolvimento das investigações experimentais.

Os ensaios para determinação da pressão lateral que o concreto exerce nas fôrmas foram realizados utilizando-se extensômetros elétricos de resistência variável tipo "strain gages", colados na superfície das barras de aço (tensores), com o emprego do adesivo instantâneo.

A experimentação consistiu, genericamente, na determinação, por meio dos extensômetros elétricos, das deformações nos tensores previamente aferidos. Tais tensores eram posicionados ao longo da altura das fôrmas dos pilares. Conhecidas as deformações, determinaram-se as forças a que estavam submetidos e, 
posteriormente, as pressões exercidas pelo concreto. A FIGURA 4.1 detalha a experimentação mencionada.

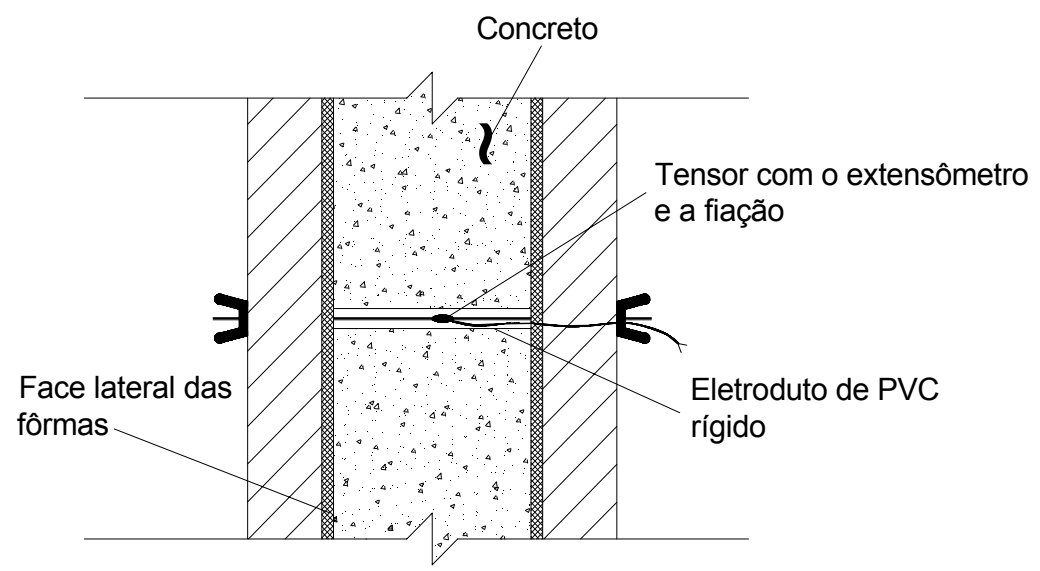

FIGURA 4.1 - Corte longitudinal do pilar com o tensor preparado para o ensaio

\subsection{Realização do ensaio}

Utilizaram-se na fabricação dos tensores barras de aço categoria CA-25 (NBR 7480/1996) com diâmetro de 6,3 mm. Inicialmente foram aferidos todos os tensores no Laboratório de Madeiras e de Estruturas de Madeira - LaMEM, do Departamento de Engenharia de Estruturas da Escola de Engenharia de São Carlos - USP, com a determinação do módulo de elasticidade para cada tensor. A FIGURA 4.2 mostra os tensores e procedimento para a aferição dos mesmos.



(a)

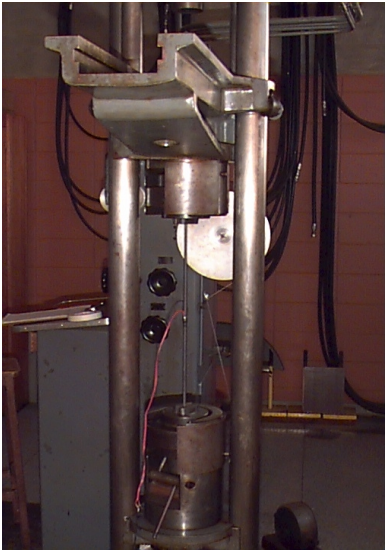

(b)

FIGURA 4.2 - Aferição dos tensores: (a) Tensores e (b) Aferição através do ensaio de tração 
O pilar escolhido para a realização do ensaio tem seção transversal $20 \mathrm{~cm} \mathrm{x}$ $100 \mathrm{~cm}$, dimensões expressivas para que os resultados não fossem mascarados pela sensibilidade do sistema de aquisição de dados. Foram posicionados na fôrma dez tensores distribuídos em cinco níveis. A FIGURA 4.3 detalha as características do pilar ensaiado e as posições dos tensores.

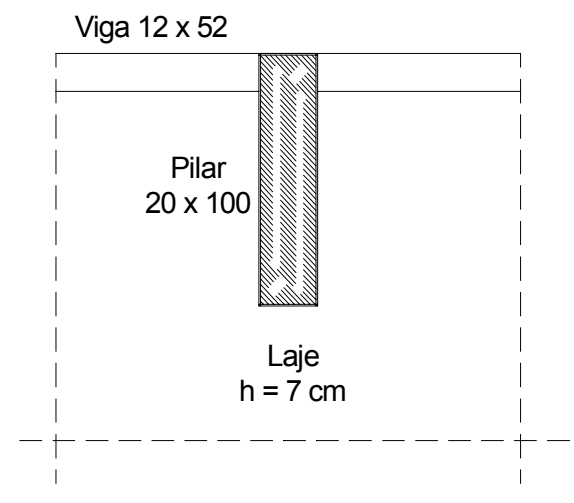

(a)

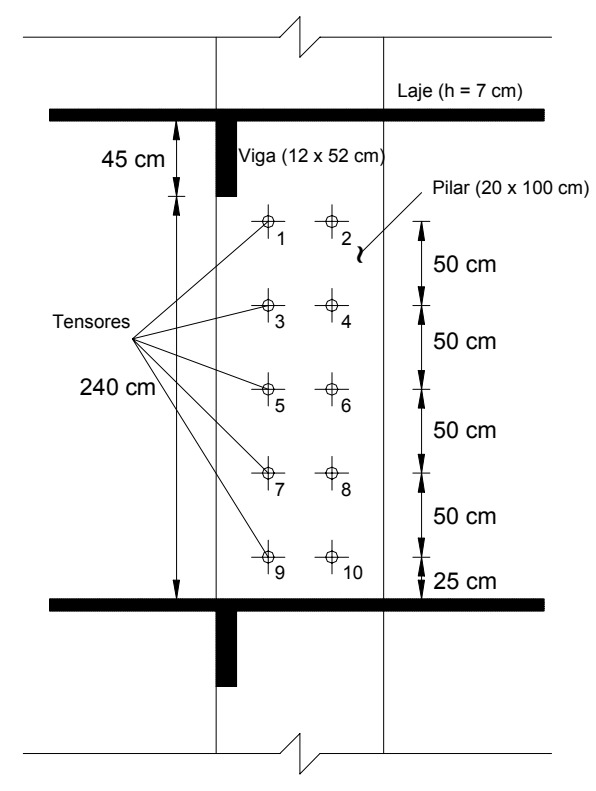

(b)

FIGURA 4.3 - Pilar Ensaiado: (a) Planta baixa e (b) Vista lateral com a posição dos tensores

As leituras foram realizadas com a utilização de medidores que acusavam diretamente a deformação (ponte para medição de deformação). Para a leitura simultânea de vários strain gages foi utilizada uma caixa seletora.

A FIGURA 4.4 mostra os equipamentos utilizados para medição em extensômetros elétricos marca Kyowa. 


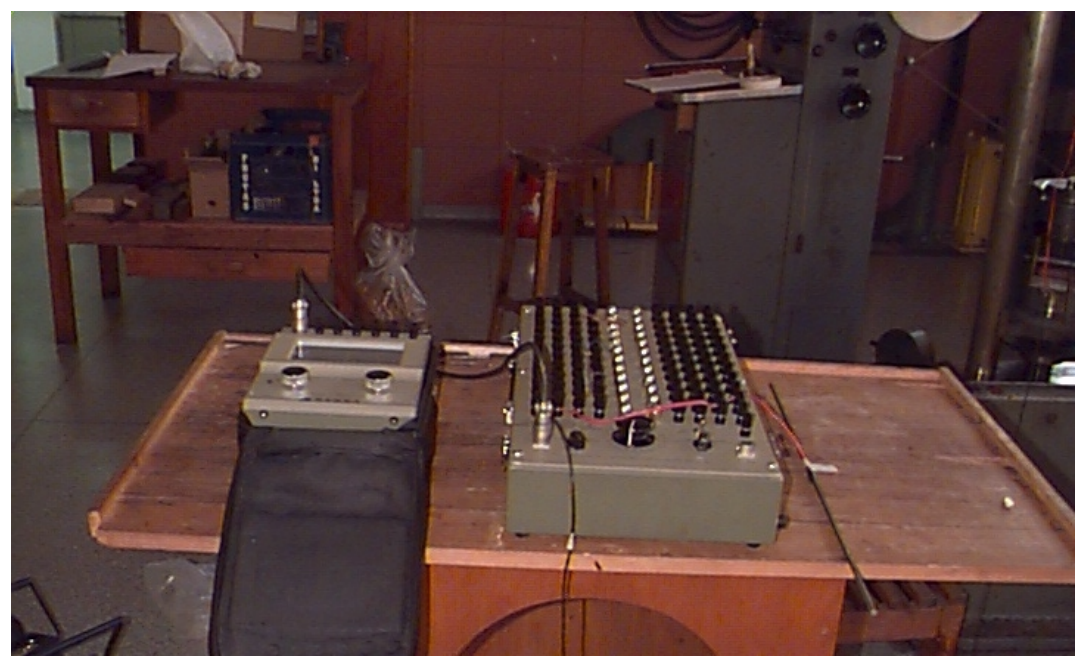

FIGURA 4.4 - Equipamentos de medição: ponte para medição de deformação e caixa seletora

Foi colado um extensômetro interligado em $1 / 4$ de ponte, situado na região central da barra de aço, para se obterem as deformações longitudinais. Para o ensaio foram instrumentadas apenas as barras centrais da fôrma nos cinco níveis, totalizando dez barras de aço ensaiadas. A FIGURA 4.5 detalha a seção transversal da fôrma para o pilar ensaiado.

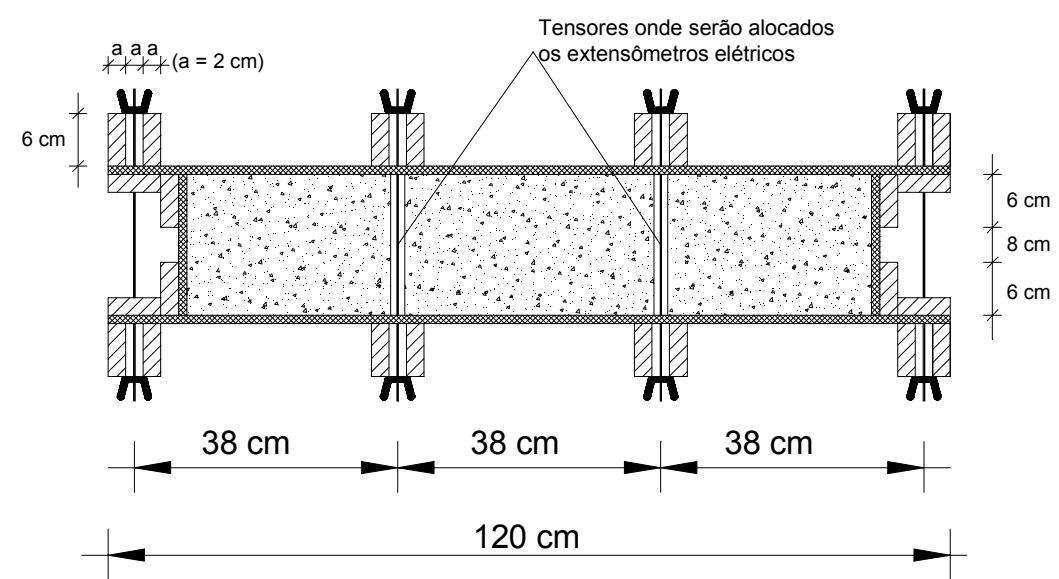

FIGURA 4.5 - Seção transversal da fôrma para o pilar instrumentado

A FIGURA 4.6 ilustra a seqüência de montagem e realização do ensaio para a determinação da pressão lateral que o concreto exercia nas fôrmas. 




(a)

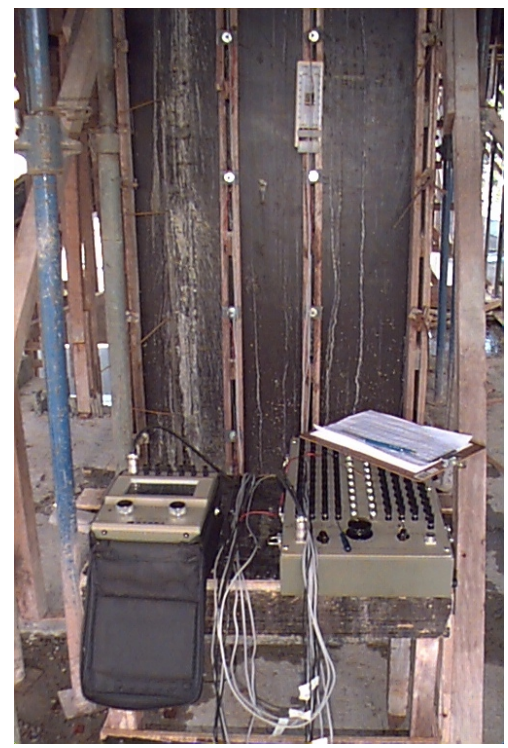

(c)

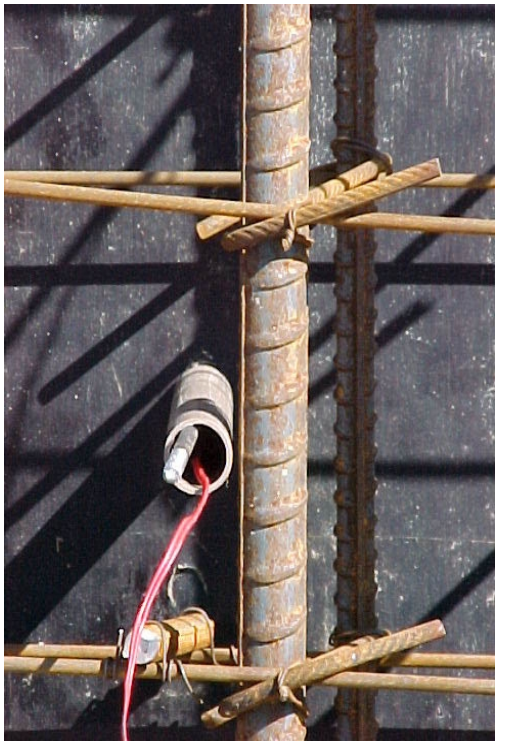

(b)

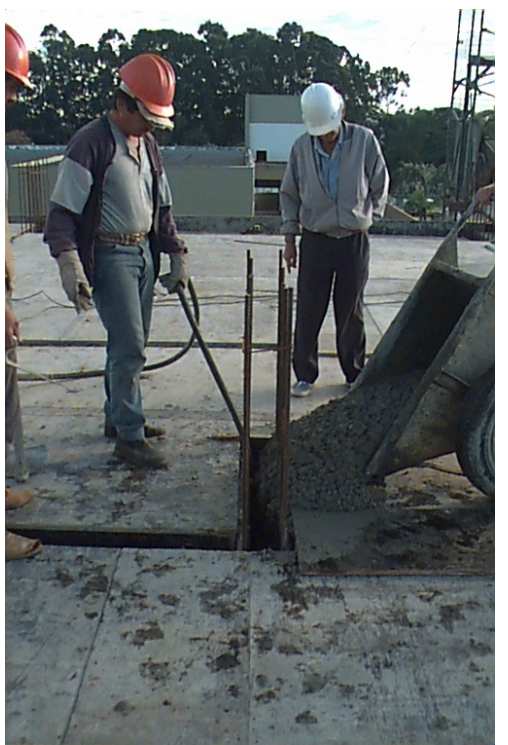

(d)

FIGURA 4.6 - Montagem e realização do ensaio: (a) pilar instrumentado; (b) detalhe do tensor no pilar; (c) equipamentos de medição e (d) concretagem

\subsection{Análise numérica}

Através das deformações definidas na investigação experimental calculamse as forças nos tensores. Torna-se necessária a definição da sistemática de cálculo para se chegar ao valor da força no tensor qualquer a partir da pressão. Com todo o procedimento de cálculo definido faz-se o processo de maneira inversa, 
ou seja, com o valor da força no tensor determinado experimentalmente, chega-se à pressão lateral que o concreto exerce na fôrma.

Para o cálculo das forças nos tensores podem ser utilizados três procedimentos. No primeiro, ilustrado pela FIGURA 4.7a, o valor da força é estimado através da área de influência do tensor.

O segundo, mostrado na FIGURA 4.7b, foi utilizado nas investigações numérica e experimental, justificado em seguida. Nele se faz a determinação de uma faixa horizontal de influência e, então, define-se a força no tensor através de uma viga com 4 apoios, onde cada apoio representa a vinculação dada pelo tensor, submetida a um carregamento uniformemente distribuído. Mais adiante este procedimento será detalhado.

O terceiro e último procedimento, mostrado na FIGURA 4.7c, pode ser considerado o mais exato, onde se define como modelo matemático para o cálculo das forças nos tensores vigas vertical e horizontal. O inconveniente é o fato de se ter nas pressões funções de formas desconhecidas, o que torna o cálculo extremamente complicado. As simplificações nas curvas das pressões para trapezoidais não implicam em simplificações no cálculo. O autor, para ter certeza de que a escolha pelo segundo procedimento não induziu a erros significativos, procedeu o cálculo através dos três procedimentos, com um carregamento uniformemente distribuído por área. Como resultado, a diferença entre o segundo (FIGURA 4.7b) e o primeiro (FIGURA 4.7a) procedimento não superou 10\%, e entre o terceiro (FIGURA 5.7c) e o segundo procedimento ficou em torno de $7 \%$. Isto valida a utilização do segundo procedimento, por sua simplicidade e precisão diante daquele que se considera o exato.

A FIGURA 4.7 ilustra os três procedimentos para o cálculo das forças nos tensores a partir da pressão lateral que o concreto exerce na fôrma. 


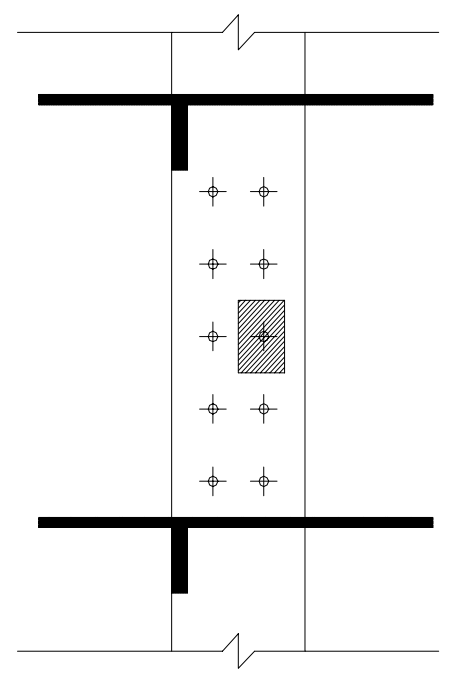

(a)

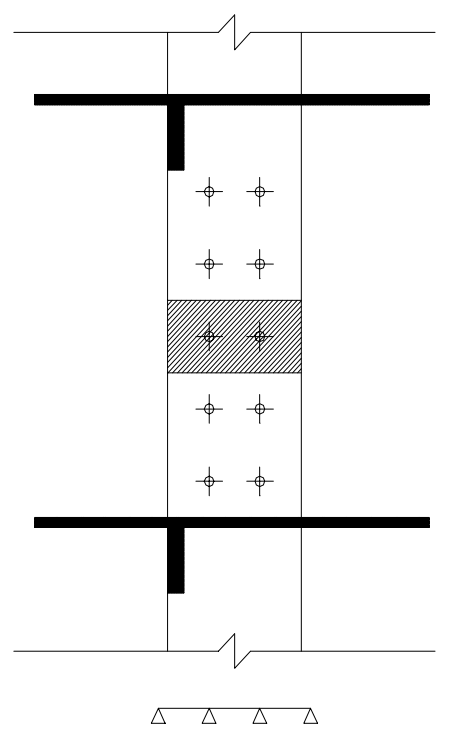

(b)

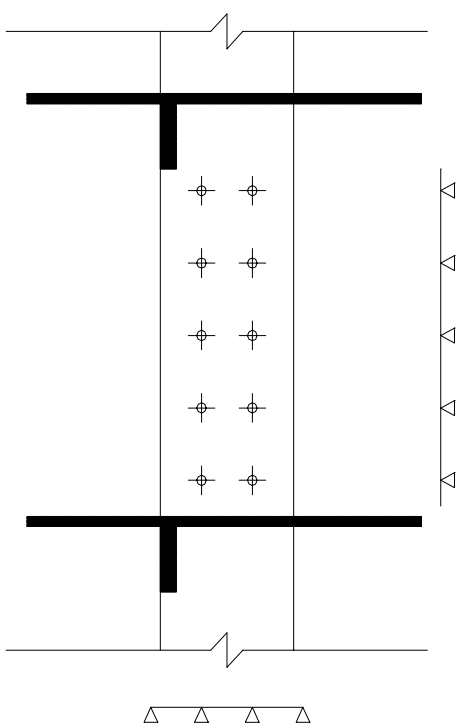

(c)

FIGURA 4.7 - Procedimentos de cálculo das forças dos tensores: (a) simplificado;

(b) utilizado no presente trabalho e (c) mais exato

Como já definido anteriormente (FIGURA 4.7) e de acordo com a seção transversal do pilar analisado (FIGURA 4.5) o modelo matemático para o cálculo das forças nos tensores foi suposto como uma viga com 4 apoios, onde cada apoio representa a vinculação dada pelo tensor, submetida a um carregamento uniformemente distribuído. Embora sejam observadas pequenas variações de vínculos e carregamentos, estes não induziram a erros significativos, como já foi mostrado. $O$ carregamento distribuído é $Q_{C}(k N / m)$, dado pela pressão atuante nas faces das fôrmas multiplicada pela largura da faixa de influência. A FIGURA 4.8, em seguida, apresenta o modelo estático de maneira mais detalhada com suas respectivas reações de apoio, que serão as forças aplicadas nos tensores.

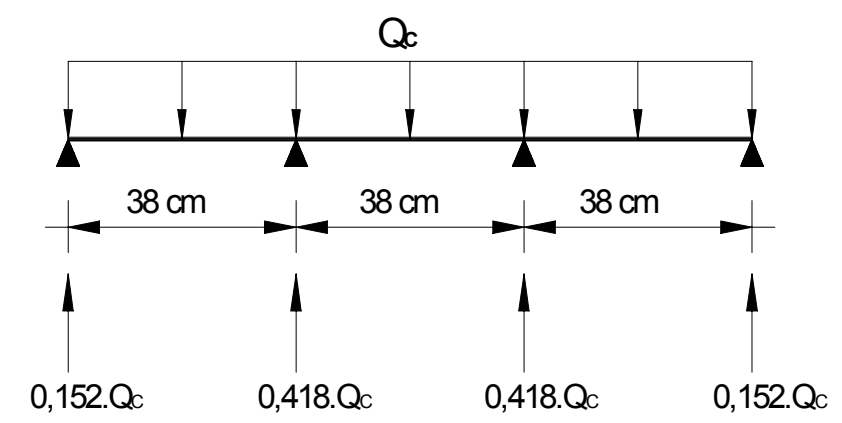

FIGURA 4.8 - Modelo estático adotado no cálculo das forças nos tensores 
De acordo com os valores das reações apresentadas, tem-se para a os apoios internos, o valor de $0,418 Q_{C}$.

\subsection{Resultados da investigação experimental}

O pilar objeto da investigação experimental foi concretado até o fundo da viga, ficando a altura do nível de concreto igual a 2,40 m. A temperatura do concreto medida na obra foi de $15^{\circ} \mathrm{C}$; a velocidade de enchimento verificada na concretagem foi de $32 \mathrm{~m} / \mathrm{h}$; a profundidade de imersão do vibrador igual a 0,5 m; na confecção do concreto não se utilizaram escórias ou resíduos finos; a altura de lançamento do concreto foi maior que $2 \mathrm{~m}$ e o abatimento verificado no concreto foi de $60 \mathrm{~mm}$. A armadura do pilar era composta por 12 barras de aço com diâmetro de $16 \mathrm{~mm}$, o que representava uma taxa de armadura igual a $1,21 \%$; com a consideração das emendas por traspasse essa taxa dobra, ficando 2,42\%.

Durante o ensaio os dados (deformações) foram obtidos no término da concretagem e a cada 15 minutos até que os decréscimos não se tornassem mais significativos.

O gráfico da FIGURA 4.9 mostra as pressões nos vários estágios de tempo até 60 minutos após o término da concretagem. Em seguida, na TABELA 4.1, estão apresentados os valores das pressões no término da concretagem.

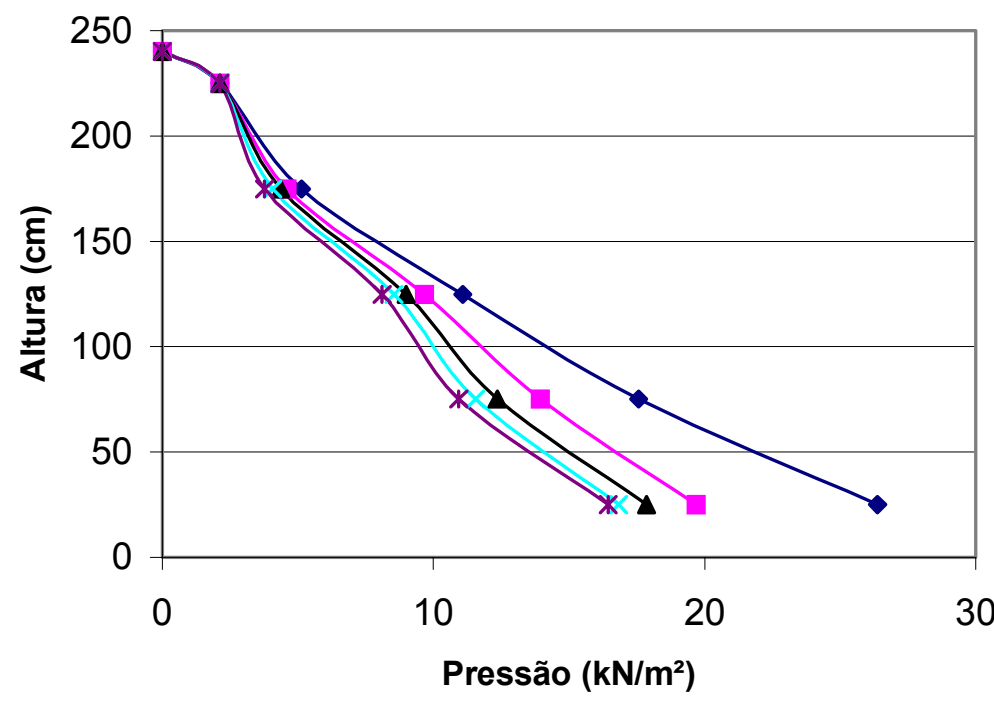

$\multimap$ Término do Enchimento

$\rightarrow-$ Após $15 \mathrm{~min}$

$\neg$ Após $30 \mathrm{~min}$

$\times$ Após $45 \mathrm{~min}$

*-Após $60 \mathrm{~min}$

FIGURA 4.9 - Gráfico das pressões nos vários estágios de tempo 
TABELA 4.1 - Valores das pressões no término da concretagem

\begin{tabular}{|c|c|c|c|}
\hline Tensor (altura) & $\begin{array}{c}\text { Força no tensor } \\
\text { (kN) }\end{array}$ & Pressão $\left(k N / m^{2}\right)$ & $\begin{array}{c}\text { Pressão } \\
\text { Média }\left(\mathrm{kN} / \mathrm{m}^{2}\right)\end{array}$ \\
\hline $01(225 \mathrm{~cm})$ & 0,44 & 2,11 & \multirow{2}{*}{2,12} \\
\hline $02(225 \mathrm{~cm})$ & 0,45 & 2,14 & \\
\hline $03(175 \mathrm{~cm})$ & 1,04 & 4,98 & \multirow{2}{*}{5,13} \\
\hline $04(175 \mathrm{~cm})$ & 1,10 & 5,27 & \\
\hline $05(125 \mathrm{~cm})$ & 2,39 & 11,42 & \multirow{2}{*}{11,09} \\
\hline $06(125 \mathrm{~cm})$ & 2,25 & 10,76 & \\
\hline $07(75 \mathrm{~cm})$ & 3,69 & 17,65 & \multirow{2}{*}{17,58} \\
\hline $08(75 \mathrm{~cm})$ & 3,66 & 17,50 & \\
\hline $09(25 \mathrm{~cm})$ & 4,00 & 25,55 & \multirow{2}{*}{26,38} \\
\hline $10(25 \mathrm{~cm})$ & 4,26 & 27,19 & \\
\hline
\end{tabular}

\subsection{Resultados da análise numérica}

Através dos métodos estudados para o cálculo das pressões laterais máximas que o concreto exercia nas faces das fôrmas, a TABELA 4.2 apresenta os diversos valores, de acordo com cada método, para o pilar em estudo.

TABELA 4.2 - Valores das pressões máximas, segundo os métodos estudados

\begin{tabular}{|c|c|}
\hline Método & Pressão Máxima $\left(k N / m^{2}\right)$ \\
\hline CEB (1976) & $\begin{array}{c}Q_{c, h}=57,6 \mathrm{kN} / \mathrm{m}^{2} \\
Q_{\mathrm{C}, \mathrm{s}}=926,6 \mathrm{kN} / \mathrm{m}^{2} \\
Q_{\mathrm{C}, \mathrm{a}}=131 \mathrm{kN} / \mathrm{m}^{2} \\
Q_{\mathrm{C}}=Q_{\mathrm{c}, \mathrm{h}}+10=67,6 \mathrm{kN} / \mathrm{m}^{2}\end{array}$ \\
\hline $\mathrm{ACl}-347 \mathrm{R}(1988)$ & $\begin{array}{c}\mathrm{Q}=773,1 \mathrm{kN} / \mathrm{m}^{2} \\
\mathrm{Q}_{\mathrm{c}, \mathrm{h}}=56,4 \mathrm{kN} / \mathrm{m}^{2} \\
\mathrm{Q}_{\mathrm{C}, \text { máx }}=144 \mathrm{kN} / \mathrm{m}^{2}\end{array}$ \\
\hline DIN 18218 (1980) & $\begin{array}{c}\mathrm{Q}=339 \mathrm{kN} / \mathrm{m}^{2} \\
\mathrm{Q}_{\mathrm{c}, \mathrm{h}}=57,6 \mathrm{kN} / \mathrm{m}^{2}\end{array}$ \\
\hline GARDNER (1985) & $\begin{array}{c}\mathrm{Q}=94,6 \mathrm{kN} / \mathrm{m}^{2} \\
\mathrm{Q}_{\mathrm{c}, \mathrm{h}}=57,6 \mathrm{kN} / \mathrm{m}^{2}\end{array}$ \\
\hline
\end{tabular}




\begin{tabular}{c|c}
\hline Teoria do Empuxo $\left(\varphi=15^{\circ}\right)$ & $Q=10,1 \mathrm{kN} / \mathrm{m}^{2}$ \\
$Q_{\mathrm{C}, \mathrm{h}}=57,6 \mathrm{kN} / \mathrm{m}^{2}$ \\
\hline
\end{tabular}

* Os valores destacados são os considerados no cálculo.

\subsection{Análise numérica $x$ Investigação experimental}

O gráfico da FIGURA 4.10 confronta os valores experimentais com os valores numéricos dos métodos estudados. Para as curvas de pressão teóricas fazse a pressão lateral ser hidrostática a partir da superfície livre até alcançar o valor máximo $\left(Q_{C, \text { máx }} / \gamma_{c}\right)$, dado na TABELA 4.2. A partir daí, torna-se constante até a base do pilar, estando definido o diagrama de pressões do concreto.

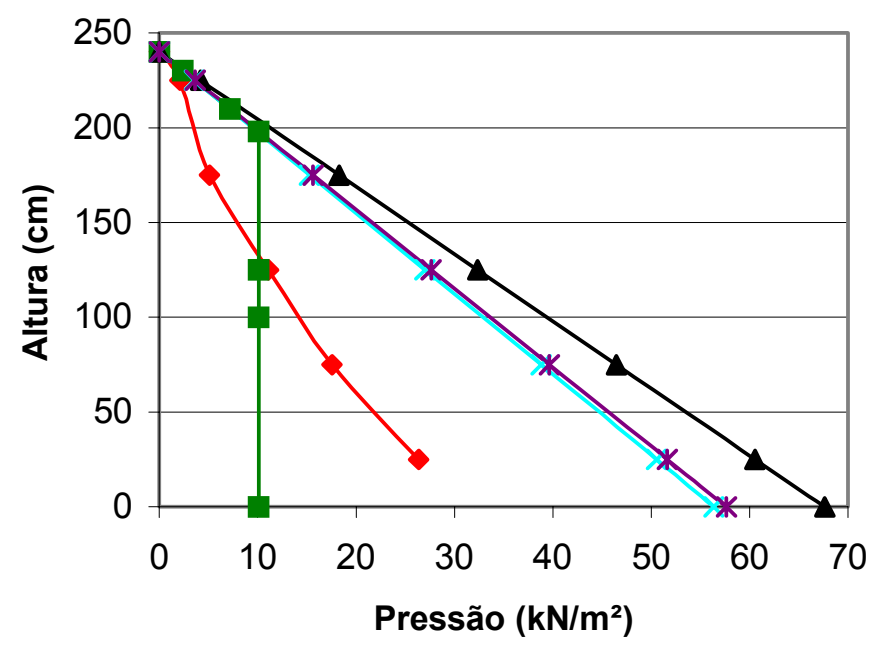

$\longrightarrow$ Experimentação

$\rightarrow$ Teoria do Empuxo

$\neg$ СEB (1976)

$\rightarrow \mathrm{ACl}-347 \mathrm{R}(1988)$

*-DIN $18218(1980)$ e

GARDNER (1985)

FIGURA 4.10 - Gráfico comparativo dos valores das pressões teóricas e experimental

\subsection{Formulação para o cálculo da pressão lateral do concreto}

Os critérios de ruptura que melhor representam o comportamento do concreto fresco são os critérios de Coulomb e de Mohr.

O critério de Coulomb pode ser expresso como: "não há ruptura se a tensão de cisalhamento não ultrapassar um valor dado pela expressão $C+f$. $\sigma$, sendo $C$ e $f$ constantes do material e $\sigma$ a tensão normal existente no plano de cisalhamento". Os parâmetros $\mathrm{C}$ e f são denominados, respectivamente, coesão e coeficiente de atrito 
interno. O critério de Mohr pode ser expresso como: "não há ruptura enquanto o círculo representativo do estado de tensões se encontrar no interior de uma curva, que é a envoltória dos círculos relativos a estados de ruptura, observados experimentalmente para o material".

Envoltórias curvas são de difícil aplicação. Por esta razão, as envoltórias de Mohr são freqüentemente substituídas por retas que melhor se ajustam à envoltória. Fazendo-se uma reta como envoltória de Mohr, seu critério de resistência fica análogo ao de Coulomb, justificando a expressão critério de MohrCoulomb, costumeiramente empregada na Mecânica dos Solos. Os dois critérios apontam para a importância da tensão normal no plano de ruptura. Observe-se a FIGURA 4.11, onde o círculo de Mohr tangencia a envoltória (reta de Coulomb).

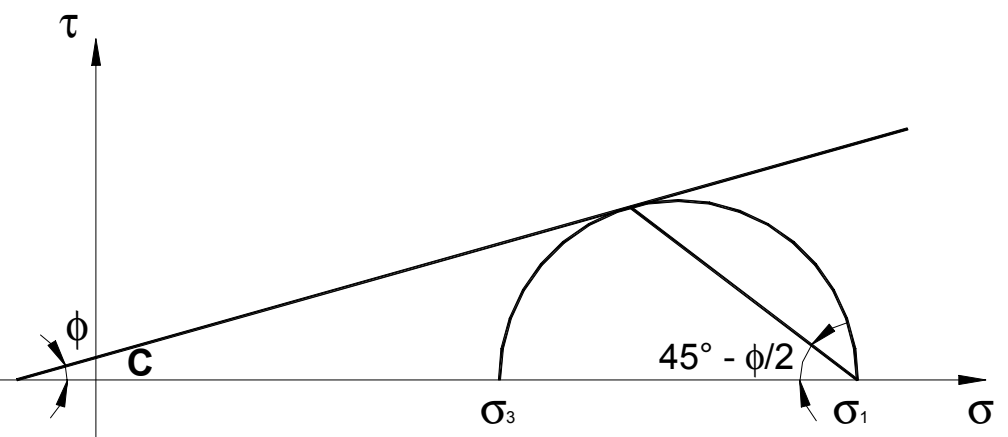

FIGURA 4.11 - Gráfico representando o critério de Mohr-Coulomb

Para o caso de se ter uma pressão lateral $\left(\sigma_{3}\right)$ e uma pressão normal $\left(\sigma_{1}\right)$, tensões principais, agindo no concreto fresco, matematicamente chega-se a EQUAÇÃO 4.1.

$\sigma_{3}=\frac{1-\operatorname{sen} \phi}{1+\operatorname{sen} \phi} \sigma_{1}-2 C \sqrt{\frac{1-\operatorname{sen} \phi}{1+\operatorname{sen} \phi}}$

Sendo:

$\sigma_{1}$ e $\sigma_{3} \quad$ as tensões principais;

$\phi \quad$ o ângulo de atrito interno do concreto fresco;

C a coesão do concreto fresco.

Considerando-se que para os casos usuais de concreto (com cimento portland comum e sem aditivos) a coesão pouco influencia na EQUAÇÃO 4.1, será feita a sua desconsideração na expressão. A mesma só é suficiente para que não 
ocorra uma segregação do concreto durante o transporte e lançamento. Ainda que, está adoção torna a situação a favor da segurança. A EQUAÇÃO 4.1 fica pois:

$\sigma_{3}=\frac{1-\operatorname{sen} \phi}{1+\operatorname{sen} \phi} \sigma_{1}$

A utilização da expressão anteriormente citada (EQUAÇÃO 4.2) depende fundamentalmente do estado de equilíbrio da estrutura que irá suportar o concreto fresco, no caso as fôrmas.

Se a estrutura sofre um deslocamento, afastando-se da massa de concreto, aparecerão tensões cisalhantes, as quais conduzem a uma diminuição da pressão. Nesse caso ter-se-á para o valor da tensão principal $\sigma_{1} \circ$ valor dado pelo peso próprio do concreto fresco $\left(\sigma_{1}=\gamma_{c} \mathrm{H}\right.$, com $\left.\gamma_{c}=24 \mathrm{kN} / \mathrm{m}^{3}\right)$, e para a tensão principal $\sigma_{3}$, conseqüentemente, o valor da pressão horizontal $\left(Q_{C, h}\right)$.

$\mathrm{Q}_{\mathrm{C}, \mathrm{h}}=\frac{1-\operatorname{sen} \phi}{1+\operatorname{sen} \phi} \gamma_{\mathrm{c}} \mathrm{H}$ ou $\mathrm{Q}_{\mathrm{C}, \mathrm{h}}=\mathrm{K}_{\mathrm{a}} \gamma_{\mathrm{c}} \mathrm{H}$

Se, ao contrário, a estrutura desloca-se de encontro à massa de concreto, também se produzirão tensões cizalhantes, as quais, aumentarão a pressão sobre a estrutura (fôrmas). Nesse caso ter-se-á para o valor da tensão principal $\sigma_{1} \circ$ valor da pressão horizontal $\left(Q_{\mathrm{C}, \mathrm{h}}\right)$, e para a tensão principal $\sigma_{3}$, conseqüentemente, o valor dado pelo peso próprio do concreto fresco $\left(\sigma_{3}=\gamma_{\mathrm{c}} \mathrm{H}\right.$, com $\left.\gamma_{\mathrm{c}}=24 \mathrm{kN} / \mathrm{m}^{3}\right)$.

$Q_{C, h}=\frac{1+\operatorname{sen} \phi}{1-\operatorname{sen} \phi} \gamma_{c} H$ ou $Q_{C, h}=K_{p} \gamma_{c} H$

Esses estados limites de equilíbrio - o primeiro, estado de equlíbrio inferior, e o segundo, equilíbrio superior - são também chamados estados de Rankine. Quando a estrutura cede uma certa quantidade que depende de suas características estruturais, esta se encontra no estado ativo. Ao contrário, quando a estrutura é que avança contra a massa de concreto fresco, tem-se um estado passivo. As pressões correspondentes chamam-se ativa e passiva e os coeficientes, ativo $\left(K_{a}\right)$ e passivo $\left(K_{p}\right)$. 
Existe ainda um estado intermediário, em que a estrutura não sofre deslocamentos, chamado de estado em repouso, não sendo computada na teoria de Mohr-Coulomb. Entretanto, Jaky (1944) apud CAPUTO (1987) chegou a uma expressão para o cáculo do coeficiente em repouso, obtida experimentalmente, adequada para materiais com ou sem coesão.

$\mathrm{K}_{0}=1-\operatorname{sen} \phi$

De acordo com o comprotamento das fôrmas, onde as mesmas não sofrem grandes deslocamentos, tem-se um estado de equilíbrio mais próximo o de repouso.

Então, na presente proposta, admite-se que a pressão que o concreto exerce sobre o plano cresce linearmente com a profundidade, tendo valor máximo igual a:

$Q_{C, h}=(1-\operatorname{sen} \phi) \cdot \gamma_{c} \cdot H$ ou $Q_{C, h}=K_{0} \cdot \gamma_{c} \cdot H$

Sendo:

$\gamma_{c} \quad$ o peso específico do concreto, igual a $24 \mathrm{kN} / \mathrm{m}^{2}$;

H a altura do nível do concreto;

$\phi \quad$ o ângulo de atrito interno do concreto fresco;

$\mathrm{K}_{0} \quad$ o coeficiente de empuxo em repouso.

$\mathrm{Na}$ literatura tem-se encontrado concretos onde o ângulo de atrito interno que podem variar de $8^{\circ}$ a $34^{\circ}$ ( ver TABELA 4.3).

O gráfico da FIGURA 4.12 mostra a linearização da curva experimental através do Método dos Mínimos Quadrados, para que se possa determinar o valor do coeficiente de empuxo K experimentalmente. 


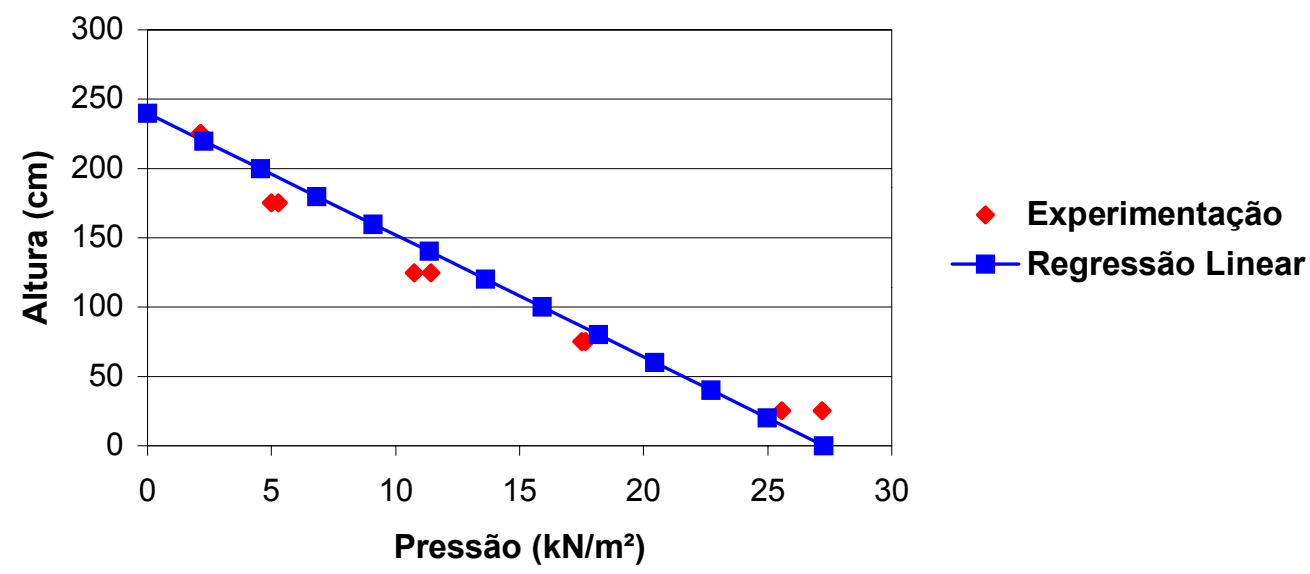

FIGURA 4.12 - Gráfico com a linearização da curva experimental

$\mathrm{O}$ valor experimental obtido para o coeficiente de empuxo $\mathrm{K}$ através da regressão linear foi de $0,47\left(Q_{\mathrm{C}, \mathrm{h}}=27,24 \mathrm{kN} / \mathrm{m}^{2}\right)$, o que dá ao concreto, de acordo com a EQUAÇÃO 4.6, um ângulo de atrito interno $\phi$ igual a $32^{\circ}$.

A conclusão tirada das muitas pesquisas realizadas pela GETHAL Fôrmas, Equipamentos e Serviços, foi que as pressões laterais exercidas pelo concreto não superam o valor de $30 \mathrm{kN} / \mathrm{m}^{2}$, para os casos correntes de pilares de edifícios resisdências e/ou comerciais.

\subsection{Considerações finais}

A determinação de uma expressão para a pressão lateral exercida pelo concreto no estado fresco, está longe de se ter uma definição última. O conhecimento do comportamento do concreto fresco é muito complexo para tratamentos teóricos rigorosos. De fato, o comportamento reológico do concreto fresco não pode ser expresso por parâmetros simples, como o concreto endurecido. A Química e Física Coloidal, importantes para justificar aspectos do comportamento dos colóides, talvez sejam partes integrantes para o conhecimento do concreto fresco.

Mais do que definir uma expressão para o cálculo das pressões exercidas pelo concreto, o experimento realizado nesse trabalho, pretende iniciar uma cadeia de ensaios sobre o assunto com uma metodologia de ensaio ora comprovada. Como uma sugestão de pesquisas posteriores, aconselha-se a determinação de parâmetros de resistência (coesão e ângulo de atrito interno) do concreto fresco 
através, por exemplo, do Ensaio de Compressão triaxial, que consiste basicamente na aplicação de um estado hidrostático de tensões e de um carregamento axial sobre um corpo-de-prova cilíndrico de concreto no estado fresco.

RITCHIE (1962) realizou ensaios de compressão triaxial em concretos frescos, variando os traços e fator água/cimento, a TABELA 4.3 apresenta os resultados dos ensaios.

TABELA 4.3 - Resultado dos Ensaios [Fonte: RITCHIE (1962)]

\begin{tabular}{c|c|c|c}
\hline Cimento/Agregado & $\begin{array}{c}\text { Fator } \\
\text { Água/Cimento }\end{array}$ & $\begin{array}{c}\text { SLUMP } \\
(\mathbf{m m})\end{array}$ & $\begin{array}{c}\text { Ângulo de Atrito } \\
\text { Interno }(\phi)\end{array}$ \\
\hline $1 / 3$ & 0,452 & 85 & $12^{\circ}$ \\
\hline $1 / 3$ & 0,477 & 125 & $11^{\circ}$ \\
\hline $1 / 3$ & 0,485 & 125 & $28^{\circ}$ \\
\hline $1 / 41 / 2$ & 0,512 & 30 & $28^{\circ}$ \\
\hline $1 / 41 / 2$ & 0,549 & 50 & $32^{\circ}$ \\
\hline $1 / 41 / 2$ & 0,561 & 70 & $30^{\circ}$ \\
\hline $1 / 6$ & 0,557 & 0 & $34^{\circ}$ \\
\hline $1 / 6$ & 0,665 & 60 & $34^{\circ}$ \\
\hline $1 / 6$ & 0,690 & 60 & ${ }^{*}$ \\
\hline $1 / 71 / 2$ & 0,676 & 0 & 20 \\
\hline $1 / 71 / 2$ & 0,775 & 40 & \\
\hline $1 / 71 / 2$ & 0,805 & & \\
\hline
\end{tabular}

Ritchie concluiu que com o aumento da proporção cimento/agregado, o ângulo de atrito interno aumentava, e que quanto maior o fator água/cimento menor era o valor de atrito interno entre as partículas de agregado, resultando no menor valor do ângulo de atrito interno. 


\section{DIMENSIONAMENTO DAS FÔRMAS}



\subsection{Generalidades}

As fôrmas para as estruturas de concreto armado devem resistir às pressões e cargas a que estão sujeitas. Deve-se assegurar uma adequada resistência e rigidez com o máximo de economia. As fôrmas devem ser projetadas com os mesmos cuidados e atenção que são utilizados no cálculo das estruturas de concreto armado. A falta do projeto de fôrmas poderá resultar num custo excessivo de material, subestimando a resistência e rigidez do mesmo, ou, na pior das hipóteses, resultar na falha do sistema de fôrmas.

Para o projeto de fôrmas é necessário conhecer as ações que estão agindo sobre as mesmas, discutido no Capítulo 3 , bem como as propriedades físicas e mecânicas dos materiais utilizados nas fôrmas.

Todos os procedimentos de dimensionamento das fôrmas discutidos em seguida, estão baseados na norma NBR 7190 (1997) - Projeto de Estruturas de Madeira. 


\subsection{Conceitos da NBR 7190 (1997)}

Com a profunda reformulação da norma NBR 7190 (1982), originariamente NB 11 (1951), baseada no método das tensões admissíveis, para a nova versão da norma brasileira NBR 7190 (1997), fundamentada no método dos estados limites, torna-se necessário esclarecer os pontos relevantes que norteiam esta transição.

O que se tem verificado é que, apesar da mudança da norma, muitos projetistas de fôrmas continuam a adotar o modelo antigo, talvez pela falta de trabalhos que esclareçam a mudança. Para que haja uma melhor assimilação pelo meio técnico, são aqui apresentados os procedimentos adotados no novo modelo normativo.

As vantagens do modelo nos estados limites sobre o das tensões admissíveis são claras, com a possibilidade de discriminar e quantificar a influência de cada uma das variáveis básicas sobre a segurança das estruturas.

\subsubsection{Cálculo das resistências características}

De posse de um lote de resistências últimas obtidas através de ensaios (NBR 9533 (1986) - Compensado - Determinação da resistência à flexão estática e NBR 9534 (1986) - Compensado - Determinação da resistência da colagem ao esforço de cisalhamento) o valor característico da resistência a ser utilizado nos cálculos deve ser estimado pela EQUAÇÃO 5.1 [FUSCO (1977) apud NBR 7190 (1997)], diferentemente do procedimento adotado na NBR 7190 (1982), que estabelecia a média aritmética para a resistência.

$x_{w k}=\left(2 \frac{x_{1}+x_{2}+\ldots+x_{\frac{n}{2}-1}}{\frac{n}{2}-1}-x_{\frac{n}{2}}\right) \cdot 1,1$

Nesta expressão, os resultados devem ser colocados em ordem crescente $\left(x_{1} \leq x_{2} \leq \ldots \leq x_{n}\right)$, desprezando-se o valor mais alto se o número de corpos de prova for ímpar, não se tomando para $\mathrm{x}_{\mathrm{wk}}$ valor inferior a $\mathrm{x}_{1}$, nem 0,7 do valor médio $\left(x_{m}\right)$. 
Tanto a resistência como o módulo de elasticidade na NBR 7190 (1982) admitiam uma umidade de madeira verde (em torno de 30\%), na NBR 7190 (1997) admite-se a umidade de equilíbrio da madeira de 12\%. Quando as investigações experimentais forem feitas com umidades $U \%$ diferentes, dentro do intervalo de $10 \%$ a $20 \%$, os resultados podem ser corrigidos por meio da expressão:

$f_{12 \%}=f_{U \%}\left[1+\frac{3(U(\%)-12)}{100}\right]$

\subsubsection{Coeficientes de ponderação da resistência para estados limites últimos e de utilização}

De acordo com a NBR 7190 (1997) o coeficiente de ponderação para estados limites últimos decorrentes de tensões de compressão tem valor básico $\gamma_{w c}$ $=1,4$. Para o estado limite último decorrente das tensões de cisalhamento o valor básico é $\gamma_{w c}=1,8$. No caso do estado limite de utilização o coeficiente de ponderação vale $\gamma_{w c}=1,0$.

\subsubsection{Valores de cálculo das resistências}

Os valores de cálculo das solicitações resistentes são determinados em função das resistências de cálculo dos materiais, definida pela expressão:

$\mathrm{x}_{\mathrm{d}}=\mathrm{k}_{\text {mod }} \frac{\mathrm{x}_{\mathrm{k}}}{\gamma_{\mathrm{m}}}$

onde $x_{k}$ é a resistência característica do material, $\gamma_{m}$ representa o coeficiente de ponderação do material e $\mathbf{k}_{\bmod }$ um coeficiente de modificação resultante do produto de três coeficientes parciais, sendo:

$\mathrm{k}_{\text {mod }}=\mathrm{k}_{\text {mod, } 1} \cdot \mathrm{k}_{\text {mod, }, 2} \cdot \mathrm{k}_{\text {mod, } 3}$ 
O coeficiente $k_{\text {mod, } 1}$ leva em conta a classe de carregamento e o tipo de material empregado, é dado pela TABELA 5.1, devendo ser escolhido conforme as classes de carregamento (ver TABELA 5.2).

TABELA 5.1 - Valores de $k_{\text {mod,1 }}$ [Fonte: NBR 7190 (1997)]

\begin{tabular}{l|c|c}
\hline \multirow{2}{*}{$\begin{array}{c}\text { Classes de } \\
\text { Carregamento }\end{array}$} & $\begin{array}{c}\text { Madeira serrada, Madeira } \\
\text { laminada colada e } \\
\text { Madeira compensada }\end{array}$ & $\begin{array}{c}\text { Madeira } \\
\text { Recomposta }\end{array}$ \\
\hline Permanente & 0,60 & 0,30 \\
\hline Longa duração & 0,70 & 0,45 \\
\hline Média duração & 0,85 & 0,65 \\
\hline Curta duração & 1,00 & 1,00 \\
\hline Instantânea & 1,10 & 1,10 \\
\hline
\end{tabular}

TABELA 5.2 - Classes de Carregamento [Fonte: NBR 7190 (1997)]

\begin{tabular}{l|l|l}
\hline \multirow{2}{*}{$\begin{array}{c}\text { Classes de } \\
\text { Carregamento }\end{array}$} & Duração acumulada & $\begin{array}{c}\text { Oção variável principal da combinação } \\
\text { duração acumulada da } \\
\text { ação característica }\end{array}$ \\
\cline { 2 - 3 } & Permanente & Vida útil da construção \\
\hline Lermanente & Longa duração & Mais de seis meses \\
\hline Média duração & Média duração & Uma semana a seis meses \\
\hline Curta duração & Curta duração & Menos de uma semana \\
\hline Instantânea & Instantânea & Muito curta \\
\hline
\end{tabular}

O coeficiente parcial de modificação $k_{\text {mod,2 }}$ considera possíveis variações de resistência ao longo do tempo em função da classe de umidade (ver TABELA 5.4), dado pela TABELA 5.3 . 
TABELA 5.3 - Valores de $\mathrm{k}_{\text {mod,2 }}$ [Fonte: NBR 7190 (1997)]

\begin{tabular}{c|c|c}
\hline $\begin{array}{c}\text { Classes de } \\
\text { Umidade }\end{array}$ & $\begin{array}{c}\text { Madeira serrada, Madeira } \\
\text { laminada colada e } \\
\text { Madeira compensada }\end{array}$ & $\begin{array}{c}\text { Madeira } \\
\text { Recomposta }\end{array}$ \\
\hline$(1)$ e (2) & 1,00 & 1,00 \\
\hline$(3)$ e (4) & 0,80 & 0,90 \\
\hline
\end{tabular}

TABELA 5.4 - Classes de Umidade [Fonte: NBR 7190 (1997)]

\begin{tabular}{c|c|c}
\hline $\begin{array}{c}\text { Classes de } \\
\text { Umidade }\end{array}$ & $\begin{array}{c}\text { Umidade relativa do } \\
\text { ambiente }\left(\mathbf{U}_{\mathrm{amb}}\right)\end{array}$ & $\begin{array}{c}\text { Umidade de equilíbrio da } \\
\text { madeira }\left(\mathbf{U}_{\mathrm{eq}}\right)\end{array}$ \\
\hline 1 & $\leq 65 \%$ & $12 \%$ \\
\hline 2 & $65 \%<\mathrm{U}_{\mathrm{amb}} \leq 75 \%$ & $15 \%$ \\
\hline 3 & $75 \%<\mathrm{U}_{\mathrm{amb}} \leq 85 \%$ & $\geq 25 \%$ \\
\hline 4 & $\begin{array}{c}\mathrm{U}_{\mathrm{amb}}>85 \% \\
\text { (durante longos períodos) }\end{array}$ & \multicolumn{2}{c}{} \\
\hline
\end{tabular}

Por fim o coeficiente $k_{\bmod , 3}$ cuida de diferenças entre a qualidade da madeira empregada na estrutura e a madeira empregada nos corpos de prova. No caso de madeira de segunda categoria, admite-se $k_{\text {mod, } 3}=0,80$, e no caso de primeira categoria, $\mathrm{k}_{\text {mod }, 3}=1,00$.

Para as chapas de madeira compensada, a classe de carregamento a ser considerada será de curta duração o que dará para o $\mathbf{k}_{\text {mod,1 }}$ um valor igual a 1,0. Considerando que as chapas foram fabricadas com um adesivo especificado para uso exterior, onde a linha de cola utilizada para unir as lâminas é tão durável quanto a própria madeira, estando estas também seladas em suas bordas e podendo ser expostas ao tempo e ao alto teor de umidade devido ao estado plástico do concreto sem que isto afete a durabilidade do painel, ter-se-á um valor igual a 1,0 para $\mathbf{k}_{\text {mod,2. }}$. Quanto ao $\mathrm{k}_{\text {mod,3, }}$, adota-se 0,8 para uma chapa compensada de segunda categoria e 1,0 para a de primeira categoria, cabendo à experiência do comprador, bem como seguindo as especificações das chapas compensadas.

Quanto à rigidez da madeira, nas verificações de segurança que dependem da mesma, o módulo de elasticidade deve ser tomado com o valor efetivo.

$$
\mathrm{E}_{\mathrm{co}, \mathrm{ef}}=\mathrm{k}_{\mathrm{mod}, 1} \cdot \mathrm{k}_{\mathrm{mod}, 2} \cdot \mathrm{k}_{\mathrm{mod}, 3} \cdot \mathrm{E}_{\mathrm{co}, \mathrm{m}}
$$


Como forma de exemplificar os conceitos abordados, a TABELA 5.5 apresenta as tensões convencionais de ruptura na flexão e os módulos de elasticidade nas direções paralela e perpendicular à grã das lâminas externas, bem como as resistências de ruptura ao cisalhamento de uma amostra de chapas de madeira compensada com 12 corpos de prova. Admite-se como hipótese que as chapas são de boa qualidade, sendo classificadas como de $1^{\text {a }}$ categoria e com teor de umidade em torno de $10 \%$. Com isso determinam-se os valores de cálculo das tensões convencionais de ruptura na flexão, resistência ao cisalhamento e o módulo de elasticidade efetivo.

TABELA 5.5 - Tensões convencionais de ruptura na flexão, resistência ao cisalhamento e módulos de elasticidade nas direções paralelas e perpendicular à grã das lâminas externas

\begin{tabular}{|c|c|c|c|c|c|}
\hline \multirow[b]{2}{*}{$\begin{array}{c}\text { Corpo } \\
\text { de } \\
\text { Prova }\end{array}$} & \multicolumn{2}{|c|}{$\begin{array}{c}\text { Direção paralela à grã das } \\
\text { lâminas externas }\end{array}$} & \multicolumn{2}{|c|}{$\begin{array}{l}\text { Direção perpendicular à } \\
\text { grã das lâminas externas }\end{array}$} & \multirow{2}{*}{$\begin{array}{c}\text { Resistência } \\
\text { ao } \\
\text { cisalhamento } \\
\text { (MPa) }\end{array}$} \\
\hline & $\begin{array}{c}\text { Tensões } \\
\text { convencionais } \\
\text { de ruptura na } \\
\text { flexão (MPa) }\end{array}$ & $\begin{array}{c}\text { Módulo de } \\
\text { Elasticidade } \\
\text { (MPa) }\end{array}$ & $\begin{array}{c}\text { Tensões } \\
\text { convencionais } \\
\text { de ruptura na } \\
\text { flexão (MPa) }\end{array}$ & $\begin{array}{c}\text { Módulo de } \\
\text { Elasticidade } \\
\text { (MPa) }\end{array}$ & \\
\hline 1 & 55,9 & 6264,2 & 39,4 & 4934,7 & 0,82 \\
\hline 2 & 60,0 & 6342,2 & 41,9 & 5115,4 & 0,88 \\
\hline 3 & 70,8 & 6831,5 & 39,6 & 5115,8 & 0,85 \\
\hline 4 & 56,3 & 6531,8 & 40,1 & 5023,6 & 0,93 \\
\hline 5 & 54,2 & 5980,0 & 41,7 & 5022,5 & 0,79 \\
\hline 6 & 57,1 & 6358,3 & 42,1 & 5225,1 & 0,75 \\
\hline 7 & 55,2 & 6255,9 & 39,3 & 4892,7 & 0,83 \\
\hline 8 & 63,5 & 6732,5 & 40,5 & 5075,3 & 0,77 \\
\hline 9 & 69,1 & 6825,1 & 40,9 & 5096,4 & 0,98 \\
\hline 10 & 59,7 & 6443,6 & 41,6 & 5053,8 & 0,96 \\
\hline 11 & 68,9 & 6798,8 & 41,3 & 5127,9 & 0,84 \\
\hline 12 & 54,8 & 6198,7 & 42,5 & 5201,2 & 0,95 \\
\hline
\end{tabular}

$\mathrm{Na}$ TABELA 5.6 estão apresentados os valores característicos das resistências à compressão nas duas direções e da resistência ao cisalhamento, de 
acordo com a EQUAÇÃO 5.1 e corrigida para a umidade de equilíbrio (12\%) através da EQUAÇÃO 5.2. São apresentados também os valores médios dos módulos de elasticidade corrigidos para a umidade de equilíbrio. Embora a umidade de equilíbrio para as chapas de madeira compensada atinja valores inferiores a 12\% (ver TABELA 2.2), devido ao processo de secagem das lâminas, para efeito de cálculo a umidade de equilíbrio a ser considerada será a recomendada pela NBR 7190 (1997), $12 \%$.

TABELA 5.6 - Valores característicos das resistências e médios dos módulos de elasticidade

\begin{tabular}{|c|c|c|c|c|}
\hline \multicolumn{2}{|c|}{$\begin{array}{l}\text { Direção paralela à grã das } \\
\text { lâminas externas }\end{array}$} & \multicolumn{2}{|c|}{$\begin{array}{c}\text { Direção perpendicular à grã } \\
\text { das lâminas externas }\end{array}$} & \multirow{2}{*}{$\begin{array}{c}\text { Resistência } \\
\text { característica } \\
\text { ao } \\
\text { cisalhamento } \\
\mathbf{f}_{\mathrm{v}, \mathrm{k}}(\mathrm{MPa})\end{array}$} \\
\hline $\begin{array}{c}\text { Resistência } \\
\text { característica à } \\
\text { compressão } \\
\mathbf{f}_{\mathrm{co}, \mathrm{k}}(\mathrm{MPa})\end{array}$ & $\begin{array}{l}\text { Módulo de } \\
\text { Elasticidade } \\
\text { médio } \mathrm{E}_{\mathrm{c} 0, \mathrm{~m}} \\
(\mathrm{MPa})\end{array}$ & $\begin{array}{c}\text { Resistência } \\
\text { característica à } \\
\text { compressão } \\
\mathbf{f}_{\mathrm{c} 90, \mathrm{k}}(\mathrm{MPa})\end{array}$ & $\begin{array}{l}\text { Módulo de } \\
\text { Elasticidade } \\
\text { médio } \mathrm{E}_{\mathrm{c} 90, \mathrm{~m}} \\
\text { (Mpa) }\end{array}$ & \\
\hline 58,81 & 6463,6 & 42,53 & 5073,7 & 1,92 \\
\hline
\end{tabular}

No exemplo hipotético apresentado tem-se para os coeficientes de modificação $k_{\bmod 1}, k_{\bmod 2}$ e $k_{\bmod 3}$ valor unitário, para o coeficiente de ponderação das tensões de compressão $\gamma_{w c}=1,4 \mathrm{e}$, das tensões de cisalhamento $\gamma_{w c}=1,8$. A TABELA 5.7 apresenta os valores de cálculo das resistências à compressão nas duas direções e da resistência ao cisalhamento, bem como o valor do módulo de elasticidade efetivo.

TABELA 5.7 - Valores de cálculo das resistências e médios dos módulos de elasticidade

\begin{tabular}{|c|c|c|c|c|}
\hline \multicolumn{2}{|c|}{$\begin{array}{l}\text { Direção paralela à grã das } \\
\text { lâminas externas }\end{array}$} & \multicolumn{2}{|c|}{$\begin{array}{l}\text { Direção perpendicular à grã } \\
\text { das lâminas externas }\end{array}$} & \multirow{2}{*}{$\begin{array}{l}\text { Resistência de } \\
\text { cálculo ao } \\
\text { cisalhamento } \\
\text { f }_{\mathrm{v}, \mathrm{d}}(\mathrm{MPa})\end{array}$} \\
\hline $\begin{array}{c}\text { Resistência de } \\
\text { cálculo à } \\
\text { compressão } \\
\text { f }_{\mathrm{c0}, \mathrm{d}}(\mathrm{MPa})\end{array}$ & $\begin{array}{c}\text { Módulo de } \\
\text { Elasticidade } \\
\text { efetivo } E_{\mathrm{c} 0, \mathrm{ef}} \\
\text { (MPa) }\end{array}$ & $\begin{array}{l}\text { Resistência de } \\
\text { cálculo à } \\
\text { compressão } \\
\mathbf{f}_{\mathrm{c90,d}}(\mathrm{MPa})\end{array}$ & $\begin{array}{c}\text { Módulo de } \\
\text { Elasticidade } \\
\text { efetivo } \mathrm{E}_{\mathrm{c} 90, \mathrm{ef}} \\
\text { (MPa) }\end{array}$ & \\
\hline 42,01 & 6463,6 & 30,38 & 5073,7 & 1,07 \\
\hline
\end{tabular}




\subsection{Flechas máximas}

Torna-se importante especificar um limite para as flechas nos membros das fôrmas, este limite previne as estruturas de concreto quanto à sua aparência (ondulações na superfície do concreto).

Para os membros das fôrmas para os quais se requer uma boa qualidade nas superfícies do concreto, a flecha será limitada em:

$\frac{\mathrm{L}}{350}$

$\frac{\mathrm{L}}{175}$ (no caso de balanços)

onde $L$ é a distância entre os centros de suporte. No caso de se ter fôrmas para estruturas de concreto onde a sua aparência se torna secundária (fôrmas para muros de contenção, por exemplo), pode-se limitar a flecha em L/250 (L/125, no caso de balanços). Percebe-se que, dependendo das condições de especificação para o concreto, pode-se trabalhar com limites menos ou mais rigorosos para a flecha. Os próprios travessões (transversinas ou longarinas) de madeira, se não passarem pela desengrossadeira são fornecidos pelas serrarias com desbitolamento que podem superar o valor da flecha máxima.

A razão da utilização dos valores limites para as flechas nos membros das fôrmas apresentados anteriormente, torna-se ainda mais coerente quando são verificados os limites estabelecidos pela NBR 6118 (1978) para as flechas nas vigas e nas lajes das estruturas de edifícios. Essa prescreve que: "...as flechas medidas a partir do plano que contém os apoios, quando atuarem todas as ações, não ultrapassarão L/300 do vão teórico, exceto no caso de balanços para os quais não ultrapassarão $L / 150$ do seu comprimento teórico...". Vale alertar que o vão $L$ ao qual a NBR 6118 (1978) se refere é o definido entre os apoios do elemento estrutural (viga ou laje). Para o caso das fôrmas o vão $L$, é medido entre os suportes do membro, ou seja, bem inferior ao designado para as estruturas de concreto. A FIGURA 5.1 ilustra a situação. 




(a)

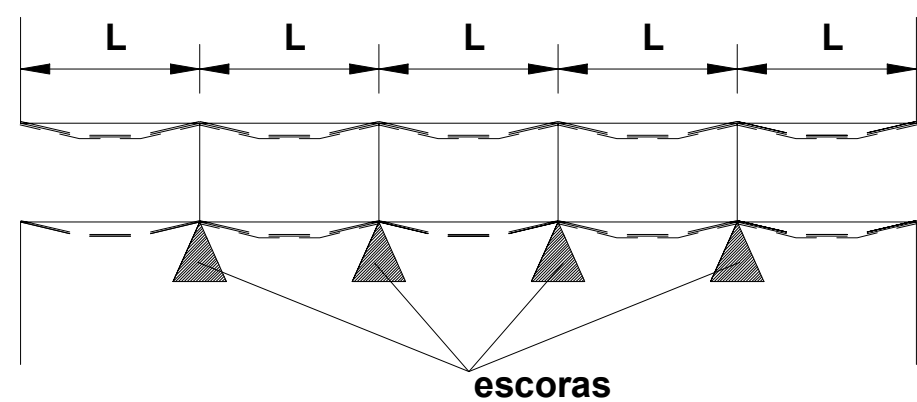

(b)

FIGURA 5.1 - (a) Flecha limite na viga como elemento estrutural e (b) flecha limite na fôrma para a viga (aumentado em 30x)

Ainda que no cálculo das fôrmas se considerem as ações permanentes (peso próprio das fôrmas e o peso do concreto mais o da armadura) e variáveis (peso dos trabalhadores, gericas, carrinhos de mão, lançamento e adensamento do concreto; etc.), para efeito do cálculo das flechas nas fôrmas, apenas as ações permanentes estarão atuando ininterruptamente.

\subsection{Flexão simples reta}

Para peças estruturais submetidas a momento fletor, cujo plano de ação contém um eixo central de inércia da seção transversal resistente, a seguinte verificação deve ser feita:

$\sigma_{\mathrm{c} 0, \mathrm{~d}} \leq \mathrm{f}_{\mathrm{c} 0, \mathrm{~d}}$

onde $\mathrm{f}_{\mathrm{c} 0, \mathrm{~d}}$ é a resistência de cálculo à compressão, definida anteriormente, e $\sigma_{\mathrm{c} 0, \mathrm{~d}}$ é a tensão normal de cálculo na seção transversal considerada. 
Os valores das tensões normais são determinados de acordo com os conceitos da resistência dos materiais, que especificam a tensão normal como sendo:

$\sigma_{\mathrm{c} 0, \mathrm{~d}}=\frac{\mathrm{M}_{\mathrm{d}}}{\mathrm{l}} \mathrm{y}_{\text {máx }}$

onde $M_{d}$ é o momento fletor de cálculo devido às ações atuantes consideradas, I o momento de inércia da seção transversal resistente em relação ao eixo central de inércia perpendicular ao plano de ação do momento fletor atuante e ymáx a maior distância da linha neutra na seção transversal considerada, por exemplo, para o caso de uma seção transversal de material homogêneo (podendo ser considerada a madeira) o valor de $y_{\text {máx }}$ é dado pela altura reduzida a metade $(\mathrm{h} / 2)$, considerando a seção com base b, pode-se rescrever a EQUAÇÃO 5.9 como:

$\sigma_{\mathrm{c} 0, \mathrm{~d}}=\frac{6 \cdot \mathrm{M}_{\mathrm{d}}}{\mathrm{b} \cdot \mathrm{h}^{2}}$

\subsection{Cisalhamento}

Nas peças submetidas à flexão com força cortante, a verificação de segurança em relação às tensões tangenciais é feita com a seguinte condição:

$\tau_{\mathrm{d}} \leq \mathrm{f}_{\mathrm{v} 0, \mathrm{~d}}$

onde $f_{\mathrm{v} 0, \mathrm{~d}}$ é a resistência de cálculo ao cisalhamento, definida anteriormente, e $\tau_{\mathrm{d}}$ é a tensão cisalhante de cálculo na seção transversal considerada.

Os valores das tensões cisalhantes são também determinados de acordo com os conceitos da resistência dos materiais, que especificam a tensão cisalhante como sendo:

$\tau_{d}=\frac{V_{d} \cdot S}{l \cdot t}$ 
onde $V_{d}$ é a força cortante de cálculo devida às ações atuantes consideradas, $S$ representa o momento estático da área acima do plano de corte considerado, I o momento de inércia da seção transversal resistente em relação ao eixo central de inércia perpendicular ao plano de ação do momento fletor atuante e t é a largura da seção transversal no plano de corte. Em peças de seção transversal retangular, de largura b e altura h, tem-se, a partir da EQUAÇÃO 5.12, o valor da máxima tensão de cisalhamento igual a:

$$
\tau_{d}=\frac{3}{2} \frac{V_{d}}{b \cdot h}
$$

\subsection{Flexão composta}

Este tipo de solicitação ocorre em diversas situações estruturais, cabendo destaque a peças submetidas à compressão axial e à ação do vento atuando perpendicularmente ao seu comprimento, a peças com carga aplicada com excentricidade e a peças com solicitação de compressão axial associada a ações que provocam flexão.

Para estas solicitações devem ser verificadas duas situações de segurança: de estabilidade, a ser feita de acordo com os critérios para o dimensionamento de peças solicitadas à compressão, apresentados no item 5.6.1; e a verificação de acordo com a mais rigorosa das duas expressões a seguir, aplicados ao ponto mais solicitado da borda mais comprimida, levando-se em conta a resistência do elemento em função dos carregamentos:

$$
\begin{aligned}
& \left(\frac{\sigma_{\mathrm{Nc}, \mathrm{d}}}{\mathrm{f}_{\mathrm{c} 0, \mathrm{~d}}}\right)^{2}+\mathrm{k}_{\mathrm{M}} \frac{\sigma_{\mathrm{Mx}, \mathrm{d}}}{\mathrm{f}_{\mathrm{c} 0, \mathrm{~d}}}+\frac{\sigma_{\mathrm{My}, \mathrm{d}}}{\mathrm{f}_{\mathrm{c} 0, \mathrm{~d}}} \leq 1 \\
& \left(\frac{\sigma_{\mathrm{Nc}, \mathrm{d}}}{\mathrm{f}_{\mathrm{c} 0, \mathrm{~d}}}\right)^{2}+\frac{\sigma_{\mathrm{Mx}, \mathrm{d}}}{\mathrm{f}_{\mathrm{c} 0, \mathrm{~d}}}+\mathrm{k}_{\mathrm{M}} \frac{\sigma_{\mathrm{My}, \mathrm{d}}}{\mathrm{f}_{\mathrm{c} 0, \mathrm{~d}}} \leq 1
\end{aligned}
$$

onde $\sigma_{\mathrm{Nc}, \mathrm{d}}$ é o valor de cálculo da parcela de tensão normal atuante em virtude apenas da força normal de compressão, $\sigma_{M x, d}$ e $\sigma_{M x, d}$ são tensões máximas devidas às componentes de flexão atuantes segundo as direções principais, $f_{c 0, d}$ é a 
resistência de cálculo à compressão paralela às fibras, e coeficiente $k_{M}$ de correção pode ser tomado com o valor de 0,5 para a seção retangular, e 1,0 para outras seções transversais, de acordo com as recomendações da NBR 7190 (1997).

\subsubsection{Estabilidade}

As peças solicitadas apenas por compressão simples devem ser dimensionadas considerando-se uma excentricidade acidental $\left(e_{a}\right)$ do esforço de compressão, devida às imperfeições geométricas das peças e das excentricidades inevitáveis dos carregamentos, considerando-se ainda os acréscimos destas excentricidades em decorrência dos efeitos de segunda ordem e, nas peças esbeltas, da fluência da madeira. A esbeltez de uma peça é definida pelo seu índice de esbeltez.

$\lambda=\frac{\mathrm{L}_{0}}{\mathrm{i}_{\min }}$

onde $\mathrm{i}_{\min }$ é o menor raio de giração da seção transversal da peça, e $\mathrm{L}_{0}$ é o comprimento efetivo da peça, sendo para peças de comprimento $L$, engastadas em uma extremidade e livre na outra dado por $L_{0}=2 L$. Nas peças de comprimento $L$, onde ambas as extremidades sejam indeslocáveis por flexão, adota-se $L_{0}=L$, não se considerando qualquer redução em virtude da eventual continuidade estrutural da peça.

De acordo com a NBR 7190 (1997), a excentricidade acidental devida às imperfeições geométricas das peças é adotada com pelo menos o valor de:

$$
e_{a}=\frac{L_{0}}{300}
$$

\section{a) Peças curtas}

Nas peças curtas, com índice de esbeltez $\lambda \leq 40$, solicitadas apenas à compressão simples, dispensa-se a consideração de eventuais efeitos de flexão. 


\section{b) Peças medianamente esbeltas}

Nas peças medianamente esbeltas, com índice de esbeltez $40<\lambda \leq 80$, solicitadas à flexocompressão com uma força normal de cálculo $\mathrm{N}_{d}$ e momento fletor de cálculo $M_{1 d}$, devem ser verificadas as condições de segurança especificadas no item 5.6, bem como a segurança em relação ao estado limite último de instabilidade, ou seja, no ponto mais comprimido da seção transversal deve ser respeitada a condição:

$\frac{\sigma_{\mathrm{N}, \mathrm{d}}}{\mathrm{f}_{\mathrm{c} 0, \mathrm{~d}}}+\frac{\sigma_{\mathrm{M}, \mathrm{d}}}{\mathrm{f}_{\mathrm{c} 0, \mathrm{~d}}} \leq 1$

aplicada isoladamente para os planos de rigidez mínima e máxima da peça, os símbolos $\sigma_{\mathrm{N}, \mathrm{d}}, \sigma_{\mathrm{M}, \mathrm{d}}$ e $\mathrm{f}_{\mathrm{c} 0, \mathrm{~d}}$ tiveram seus significados definidos anteriormente (item 5.6).

O momento fletor $M_{d}$ que entra no cálculo do valor da tensão de compressão $\left(\sigma_{\mathrm{M}, \mathrm{d}}\right)$ deve ser calculado pela expressão:

$M_{d}=N_{d}\left(e_{i}+e_{a}\right)\left(\frac{F_{E}}{F_{E}-N_{d}}\right)$

onde $e_{i}$ é a excentricidade inicial, decorrente da relação entre o momento fletor de cálculo $M_{1 d}$ e a força normal de cálculo $N_{d}$, será tomada com valor não inferior a $\mathrm{h} / 30$, sendo $\mathrm{h}$ a altura da seção transversal referente ao plano de verificação. $F_{E}$ é a carga crítica, expressa por:

$\mathrm{F}_{\mathrm{E}}=\frac{\pi^{2} \mathrm{E}_{\mathrm{c} 0 \mathrm{ef}} \mathrm{I}}{\mathrm{L}_{0}^{2}}$

onde I é o momento de inércia da seção transversal da peça relativo ao plano de flexão em que se está verificando a condição de segurança, e $E_{c 0, \text { ef }} \mathrm{O}$ módulo de elasticidade transversal com o valor efetivo. 


\section{c) Peças esbeltas}

Nas peças esbeltas, com índice de esbeltez $\lambda>80$, não se permitindo valor maior que 140 , solicitadas à flexocompressão com uma força normal de cálculo $N_{d}$ e momento fletor de cálculo $M_{1 d}$, devem ser verificadas as condições de segurança especificadas no item 5.6, bem como a segurança em relação ao estado limite último de instabilidade, ou seja, no ponto mais comprimido da seção transversal deve ser respeitada a condição da EQUAÇÃO 5.18.

O momento fletor $M_{d}$ que entra no cálculo do valor da tensão de compressão $\left(\sigma_{\mathrm{M}, \mathrm{d}}\right)$ deve ser calculado pela expressão:

$M_{d}=N_{d}\left(e_{i}+e_{a}+e_{c}\right)\left(\frac{F_{E}}{F_{E}-N_{d}}\right)$

onde $\mathrm{e}_{\mathrm{c}}$ é a excentricidade suplementar de primeira ordem que representa a fluência da madeira, expressa por:

$\left.e_{c}=\left(e_{i g}+e_{a}\right)\left\{\left[\exp \left(\frac{\phi\left[N_{g k}+\left(\psi_{1}+\psi_{2} N_{q k}\right]\right.}{F_{E}-\left[N_{g k}+\left(\psi_{1}+\psi_{2}\right) N_{q k}\right.}\right]\right)\right]-1\right\}$

onde $e_{i g}$ é a excentricidade inicial devida às ações permanentes, decorrente da relação entre o momento fletor de cálculo devido apenas às ações permanentes $M_{1 g, d}$ e a força normal de cálculo devido apenas às ações permanentes $N_{g, d}$. $O$ coeficiente de fluência $\phi$ é dado pela TABELA 5.8.

TABELA 5.8 - Coeficiente de fluência $\phi$ [Fonte: NBR 7190 (1997)]

\begin{tabular}{l|c|c}
\hline \multicolumn{1}{c|}{$\begin{array}{c}\text { Classes de } \\
\text { Carregamento }\end{array}$} & \multicolumn{2}{c}{ Classes de umidade } \\
\cline { 2 - 3 } & $(1)$ e (2) & $(3)$ e (4) \\
\hline Permanente ou de longa duração & 0,8 & 2,0 \\
\hline Média duração & 0,3 & 1,0 \\
\hline Curta duração & 0,1 & 0,5 \\
\hline
\end{tabular}

Ainda, $\mathrm{N}_{\mathrm{gk}}$ e $\mathrm{N}_{\mathrm{qk}}$ são os valores característicos da força normal devidos às cargas permanentes e variáveis, respectivamente, e $\psi_{1}$ e $\psi_{2}$, fatores de utilização 
estabelecidos pela NBR 7190 (1997), onde a soma dos mesmos deverá ser inferior à unidade $\left(\psi_{1}+\psi_{2} \leq 1\right)$.

\subsubsection{Peças compostas}

Nos sistemas de fôrmas para concreto é comum encontrar algumas peças compostas solidarizadas descontinuamente por chapas laterais, é o caso, por exemplo, do escoramento das vigas (garfos), conforme ilustrado na FIGURA 5.2.

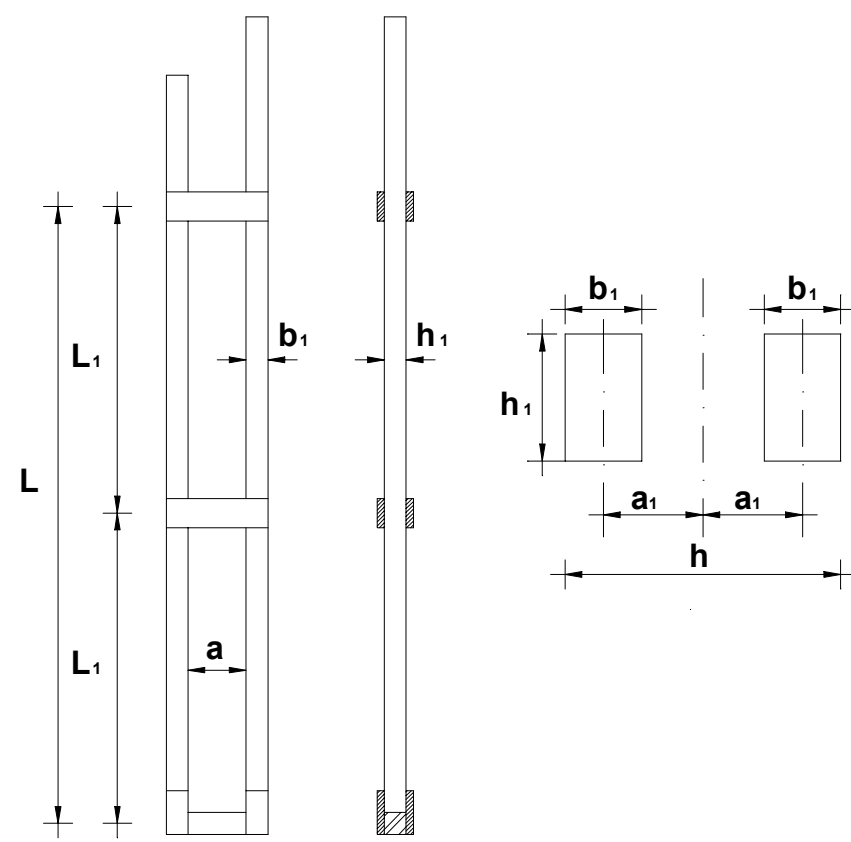

FIGURA 5.2 - Vista frontal, lateral e seção transversal de um garfo, usado para o escoramento das vigas

Segundo a NBR 7190 (1997), os espaçadores devem estar igualmente afastados entre si ao longo do comprimento $L$ da peça. Sua fixação aos elementos componentes (espaçadores interpostos e/ou chapas laterais) deve ser feita por ligações rígidas com pregos ou parafusos, conforme item 5.7, a seguir.

De acordo com as seções mostradas na FIGURA 5.3, a verificação admite algumas relações, apresentadas em seguida. 


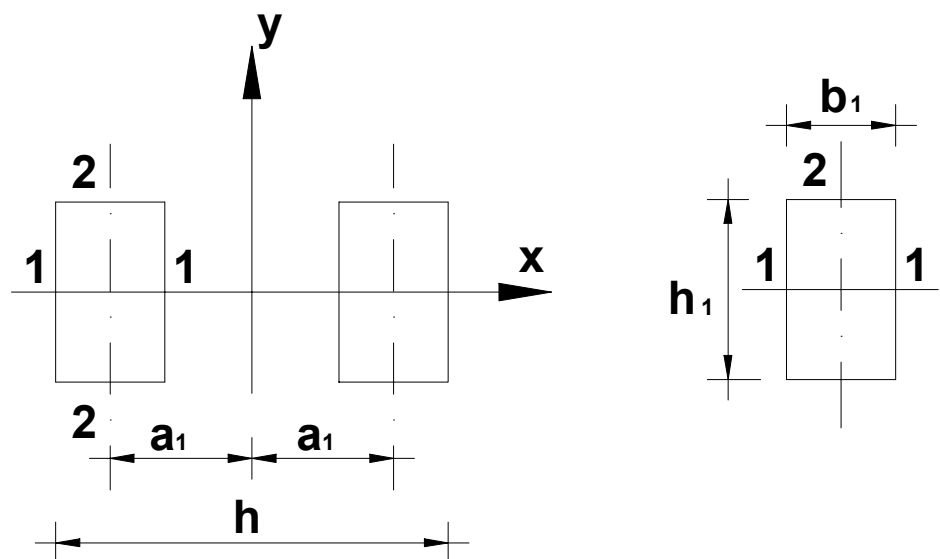

FIGURA 5.3 - Seção transversal do garfo e do elemento que compõe o mesmo

Para a seção do elemento componente tem-se:

$A_{1}=b_{1} h_{1}$

$l_{1}=\frac{b_{1} h_{1}^{3}}{12}$

$\mathrm{I}_{2}=\frac{\mathrm{h}_{1} \mathrm{~b}_{1}^{3}}{12}$

Para a seção composta tem-se então:

$A=2 A_{1}$

$\mathrm{I}_{\mathrm{x}}=2 \mathrm{I}_{1}$

$\mathrm{I}_{\mathrm{y}}=2 \mathrm{I}_{2}+2 \mathrm{~A}_{1} \mathrm{a}_{1}^{2}$

$\mathrm{I}_{\mathrm{y}, \mathrm{ef}}=\beta \mathrm{I}_{\mathrm{y}}$

com 
$\beta=\frac{\mathrm{I}_{2} \mathrm{~m}^{2}}{\mathrm{I}_{2} \mathrm{~m}^{2}+\alpha_{\mathrm{y}} \mathrm{I}_{\mathrm{y}}}$

onde $\mathrm{m}$ é o número de intervalos de comprimento $L_{1}$ em que fica dividido o comprimento $L$ total da peça, ver FIGURA 5.2. E, $\alpha_{y}$ um coeficiente igual a 1,25, para espaçadores interpostos e 2,25, para chapas laterais de fixação.

Após a definição das relações, a verificação deve ser feita como se a peça fosse maciça de seção transversal com área $A$ e momentos de inércia $I_{x}$ e $I_{y, e f}$.

Nessa verificação, as condições de segurança são especificadas através da expressão dada por:

$\frac{N_{d}}{A}+\frac{M_{d} b_{1}}{2 l_{y, \text { ef }}}+\frac{M_{d}}{2 a_{1} A_{1}}\left(1-\frac{2 l_{2}}{I_{y, e f}}\right) \leq f_{c 0, d}$

Ainda de acordo com a NBR 7190 (1997), a segurança dos espaçadores e de suas ligações com os elementos componentes deve ser verificada para um esforço de cisalhamento cujo valor convencional de cálculo é dado por:

$V_{d}=A_{1} f_{v 0, d} \frac{L_{1}}{a_{1}}$

Dispensa-se a verificação da estabilidade local dos trechos de comprimento $L_{1}$ dos elementos componentes, desde que respeitadas as limitações:

$9 b_{1} \leq L_{1} \leq 18 b_{1} ;$

$a \leq 3 b_{1}$ para peças interpostas;

$a \leq 6 b_{1}$ para peças com chapas laterais.

\subsection{Ligações}

$\mathrm{Na}$ execução das fôrmas para concreto as ligações são efetuadas, em geral, por pregos. Há, no entanto, uma grande variedade de pregos disponíveis no mercado, as vantagens na escolha de um único tipo de prego em todas as ligações são muitas. Entre elas estaria o controle do consumo e a rapidez do serviço, um 
baixo desperdício, em geral causado por desvios diários, em pequenas quantidades, e por perdas devidas à má utilização e negligência.

Dentre os pregos encontrados comercialmente, recomenda-se que sejam utilizados os de nomenclatura (comercial): $17 \times 24$ (diâmetro de $3,0 \mathrm{~mm} \mathrm{e}$ comprimento de $55 \mathrm{~mm}$ ), $18 \times 24$ (diâmetro de $3,4 \mathrm{~mm}$ e comprimento de $55 \mathrm{~mm}$ ) e 18 x 30 (diâmetro de $3,4 \mathrm{~mm}$ e comprimento de $69 \mathrm{~mm}$ ). O primeiro quando se prevê um despregamento posteriormente (chapas compensadas com as transversinas, por exemplo), o segundo e o terceiro para uma ligação mais prolongada, ou até definitiva (fabricação dos garfos).

Uma outra solução seria a utilização de pregos com duas cabeças quando se pretende fazer futuras modificações nas fôrmas, ou seja, na transição dos pavimentos atípicos para os pavimentos tipo. Isto é de grande valia, pois não somente simplifica e acelera as modificações, como permite melhor aproveitamento do material.

Quando se trata da ligação entre os sarrafos e as chapas de madeira compensada, deve-se usar pregos de bitola e comprimento menores, como por exemplo 14 x 18 (diâmetro de 2,2 mm e comprimento de $41 \mathrm{~mm}$ ) e 15 x 18 (diâmetro de 2,4 $\mathrm{mm}$ e comprimento de $41 \mathrm{~mm}$ ). Essa escolha é muito mais um detalhe construtivo que estrutural.

Percebe-se que a variedade quanto ao comprimento e a bitola dos pregos é muito vasta. Cabe ao projetista uniformizar o máximo a utilização desses pregos na execução e montagem das fôrmas, simplificando o trabalho. Na TABELA 5.9 são apresentadas algumas dimensões dos pregos encontrados no mercado.

TABELA 5.9 - Algumas dimensões de pregos

\begin{tabular}{c|c|c}
\hline Nomenclatura Comercial & Bitola $(\mathrm{mm})$ & Comprimento $(\mathrm{mm})$ \\
\hline $10 \times 12$ & 1,50 & 28 \\
\hline $11 \times 18$ & 1,60 & 34 \\
\hline $12 \times 15$ & 1,80 & 41 \\
\hline $13 \times 18$ & 2,00 & 41 \\
\hline $14 \times 18$ & 2,20 & 43 \\
\hline $14 \times 21$ & 2,20 & 62 \\
\hline $14 \times 27$ & 2,20 & 41 \\
\hline $15 \times 18$ & 2,40 & 48 \\
\hline
\end{tabular}




\begin{tabular}{|c|c|c|}
\hline $15 \times 27$ & 2,40 & 62 \\
\hline $16 \times 21$ & 2,70 & 48 \\
\hline $16 \times 24$ & 2,70 & 55 \\
\hline $16 \times 27$ & 2,70 & 62 \\
\hline $17 \times 24$ & 3,00 & 55 \\
\hline $17 \times 27$ & 3,00 & 62 \\
\hline $17 \times 30$ & 3,00 & 69 \\
\hline $18 \times 24$ & 3,40 & 55 \\
\hline $18 \times 27$ & 3,40 & 62 \\
\hline $18 \times 30$ & 3,40 & 69 \\
\hline $18 \times 33$ & 3,40 & 76 \\
\hline $18 \times 36$ & 3,40 & 83 \\
\hline $19 \times 27$ & 3,90 & 62 \\
\hline $19 \times 30$ & 3,90 & 69 \\
\hline $19 \times 33$ & 3,90 & 76 \\
\hline $19 \times 36$ & 3,90 & 83 \\
\hline $19 \times 39$ & 3,90 & 90 \\
\hline $20 \times 30$ & 4,40 & 69 \\
\hline $20 \times 33$ & 4,40 & 76 \\
\hline $20 \times 39$ & 4,40 & 90 \\
\hline $20 \times 42$ & 4,40 & 96 \\
\hline $20 \times 48$ & 4,40 & 110 \\
\hline $21 \times 33$ & 4,90 & 76 \\
\hline
\end{tabular}

No cálculo das ligações a NBR 7190 (1997) não permite a consideração do atrito entre as superfícies de contato, nem de esforços transmitidos por estribos, braçadeiras ou grampos. A madeira, quando perfurada, pode apresentar problemas de fendilhamento. Para evitá-lo devem ser obedecidos alguns critérios apresentados pela NBR 7190 (1997).

O estado limite último de uma ligação é atingido por deficiência de resistência da madeira ou do elemento de ligação. O dimensionamento da ligação é feito pela seguinte condição de segurança:

$$
\mathrm{S}_{\mathrm{d}} \leq \mathrm{R}_{\mathrm{d}}
$$


onde $S_{d}$ é o valor de cálculo da solicitação e $R_{d} O$ valor de cálculo da resistência.

A NBR 7190 (1997), na execução de estruturas provisórias, dispensa a préfuração, desde que sejam observados alguns critérios: utilização de madeira de baixa densidade $\left(\rho_{\mathrm{ap}} \leq 600 \mathrm{~kg} / \mathrm{m}^{3}\right.$ ), diâmetro máximo do prego de $1 / 6$ da espessura da peça de madeira mais delgada e espaçamento mínimo entre os pregos de 10 vezes o diâmetro.

Não será dada tanta ênfase ao processo de cálculo das ligações, pois quando respeitadas as disposições construtivas (ver Capítulo 6), certamente a ligação estará estruturalmente segura, respeitando a EQUAÇÃO 5.33. É importante não generalizar esse procedimento, procurando analisar os casos que necessitem de maior atenção, através da NBR 7190 (1997).

\subsection{Dimensionamento dos subsistemas que compõem o sistema de fôrmas}

O projeto das fôrmas para uma estrutura de concreto armado pode não ser tão elaborado e desenvolvido quanto o da própria estrutura de concreto, entretanto, a ele deve ser dada a mesma importância. São feitas hipóteses simplificadoras e a consideração das diferentes partes da estrutura é feita individualmente. Como já mencionado anteriormente, a estrutura do sistema de fôrmas é analisada com sua decomposição num conjunto de fôrmas para pilares, lajes e vigas. Cada um desses elementos é dimensionado separadamente.

O dimensionamento dos elementos deve ser feito de modo criterioso passando-se por todos os componentes da estrutura. Um método para desenvolvimento deste estudo é efetuar-se a análise partindo-se do molde, ou seja, da peça em contato com o concreto, passando-se para a estrutura do molde e para o escoramento.

Como se verá a seguir, o cálculo resume-se, para elementos fletidos, à investigação quanto à ruptura na flexão, quanto às deformações excessivas e à ruptura no cisalhamento. Para elementos submetidos à flexão composta (escoras, por exemplo), deve-se além de verificar a estabilidade, quando necessário, também a condição de segurança relativa à resistência de ruptura das seções transversais. Para elementos submetidos a solicitações não comentadas, deverá se proceder o 
devido cálculo, ficando a responsabilidade das condições peculiares de cada projeto a cargo do projetista.

\subsubsection{Subsistema de fôrmas para lajes}

O primeiro passo é a determinação do carregamento, conforme amplamente discutido no Capítulo 3. Depois, passa-se para o cálculo do molde (assoalho) das lajes (chapas de madeira compensada), definindo o espaçamento das transversinas.

As chapas de madeira compensada podem ser apoiadas em duas ou mais transversinas, sendo portanto dimensionadas como vigas de largura unitária isostáticas ou contínuas (FIGURA 5.4).

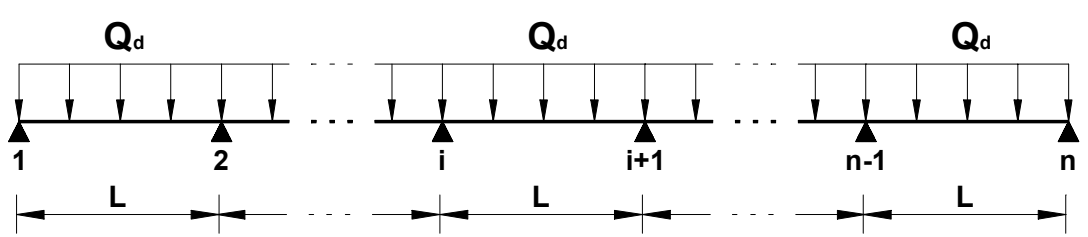

FIGURA 5.4 - Esquema estático da chapa de madeira compensada, dois ou mais apoios

Deve-se proceder às verificações das solicitações normais e tangenciais, bem como garantir que as flechas estejam dentro dos limites estabelecidos. $O$ momento fletor máximo, a força cortante máxima e a flecha máxima são função do sistema estático pré-estabelecido.

$$
\begin{aligned}
& \mathrm{M}_{\text {máx }}=\mathrm{K}_{\mathrm{M}} \mathrm{Q}_{\mathrm{d}} \mathrm{L}^{2} \\
& \mathrm{~V}_{\text {máx }}=\mathrm{K}_{\mathrm{V}} \mathrm{Q}_{\mathrm{d}} \mathrm{L} \\
& \mathrm{f}_{\text {máx }}=\mathrm{K}_{\mathrm{f}} \frac{\mathrm{QL}^{4}}{\mathrm{El}}
\end{aligned}
$$


onde os coeficientes $\mathrm{K}_{\mathrm{M}}, \mathrm{K}_{\mathrm{V}}$ e $\mathrm{K}_{\mathrm{f}}$ referentes ao momento fletor máximo, a força cortante máxima e a flecha máxima, respectivamente, são função do sistema estático adotado.

A TABELA 5.10, em seguida, apresenta as reações e os coeficientes $K_{M}, K_{V}$ e $\mathrm{K}_{\mathrm{f}}$ para alguns modelos estático. Os índices mostram onde ocorre, por exemplo, o índice $m$ indica no meio do vão, 2 no segundo apoio, etc. (ver FIGURA 5.4).

TABELA 5.10 - Coeficientes $\mathrm{K}_{\mathrm{M}}, \mathrm{K}_{\mathrm{v}}$ e $\mathrm{K}_{\mathrm{f}}$

\begin{tabular}{|c|c|c|c|c|}
\hline $\begin{array}{l}\text { Número } \\
\text { de vãos }\end{array}$ & Reações & $\begin{array}{l}\text { Momento } \\
\text { máximo }\end{array}$ & $\begin{array}{l}\text { Cortante } \\
\text { máximo }\end{array}$ & $\begin{array}{l}\text { Flecha máxima } \\
\text { no meio do vão }\end{array}$ \\
\hline 1 & $R_{1}=R_{2}=1 / 2$ & $\mathrm{~K}_{\mathrm{M}_{\mathrm{m}}}=1 / 8$ & $\mathrm{~K}_{\mathrm{V}_{1}}=5 / 8^{1}$ & $K_{f}=5 / 384$ \\
\hline 2 & $\begin{array}{c}\mathrm{R}_{1}=\mathrm{R}_{3}=3 / 8 \\
\mathrm{R}_{2}=5 / 4\end{array}$ & $\mathrm{~K}_{\mathrm{M}_{2}}=1 / 8$ & $\mathrm{~K}_{\mathrm{V}_{2}}=5 / 8^{2}$ & $K_{f}=1 / 192$ \\
\hline 3 & $\begin{array}{l}\mathrm{R}_{1}=\mathrm{R}_{4}=4 / 10 \\
\mathrm{R}_{2}=\mathrm{R}_{3}=11 / 10\end{array}$ & $\mathrm{~K}_{\mathrm{M}_{2}}=1 / 10$ & $\mathrm{~K}_{\mathrm{V}_{2}}=6 / 10^{2}$ & $K_{f}=13 / 1920$ \\
\hline 4 & $\begin{array}{c}\mathrm{R}_{1}=\mathrm{R}_{5}=11 / 28 \\
\mathrm{R}_{2}=\mathrm{R}_{4}=8 / 7 \\
\mathrm{R}_{3}=13 / 14\end{array}$ & $\mathrm{~K}_{\mathrm{M}_{2}}=3 / 28$ & $\mathrm{~K}_{\mathrm{V}_{2}}=17 / 2{ }^{2}$ & $K_{f}=17 / 2688$ \\
\hline 5 & $\begin{array}{l}\mathrm{R}_{1}=\mathrm{R}_{6}=15 / 38 \\
\mathrm{R}_{2}=\mathrm{R}_{5}=43 / 38 \\
\mathrm{R}_{3}=\mathrm{R}_{4}=37 / 38\end{array}$ & $\mathrm{~K}_{\mathrm{M}_{2}}=2 / 19$ & $\mathrm{~K}_{\mathrm{V}_{2}}=23 / 38^{2}$ & $K_{f}=47 / 7296$ \\
\hline 6 & $\begin{array}{c}\mathrm{R}_{1}=\mathrm{R}_{7}=41 / 104 \\
\mathrm{R}_{2}=\mathrm{R}_{6}=59 / 52 \\
\mathrm{R}_{3}=\mathrm{R}_{5}=301 / 312 \\
\mathrm{R}_{4}=79 / 78\end{array}$ & $\mathrm{~K}_{\mathrm{M}_{2}}=11 / 104$ & $\mathrm{~K}_{\mathrm{V}_{2}}=63 / 104$ & $K_{f}=1 / 156$ \\
\hline
\end{tabular}

1. À direita da seção.

2. À esquerda da seção.

3. Ocorreu sempre no $1^{\circ}$ vão. 
Substituindo a EQUAÇÃO 5.34 na EQUAÇÃO 5.10 e a EQUAÇÃO 5.35 na EQUAÇÃO 5.13, tem-se para peças de seção transversal retangular (ou quadrada):

$$
\begin{aligned}
& \sigma_{\mathrm{c} 0, \mathrm{~d}}=\frac{6 \cdot \mathrm{K}_{\mathrm{M}} \cdot \mathrm{Q}_{\mathrm{d}} \cdot \mathrm{L}^{2}}{\mathrm{~b} \cdot \mathrm{h}^{2}} \\
& \tau_{\mathrm{d}}=\frac{3}{2} \frac{\mathrm{K}_{\mathrm{V}} \cdot \mathrm{Q}_{\mathrm{d}} \cdot \mathrm{L}}{\mathrm{b} \cdot \mathrm{h}}
\end{aligned}
$$

No cálculo das chapas de madeira compensada têm-se como incógnitas a espessura do painel e o espaçamento das transversinas. Como são condições dependentes uma da outra, o procedimento é determinar uma delas para que a outra simplesmente decorra da anterior.

Quanto às transversinas, estas podem estar apoiadas sobre longarinas, dependendo das dimensões da laje que será suportada pelas mesmas. Não existindo longarinas, as transversinas se apoiam diretamente nas escoras.

Assim como nas chapas de madeira compensada, deve-se proceder às verificações das solicitações normais e tangenciais, bem como garantir que as flechas estejam dentro dos limites estabelecidos, definindo o espaçamento das longarinas ou das escoras.

Para as longarinas, o procedimento é semelhante, entretanto adota-se uma simplificação. O carregamento efetivo destes componentes é constituído por uma série de cargas concentradas nas posições de apoio das transversinas. Para efeito do dimensionamento, na maioria dos casos, a simplificação mencionada se constitui na adoção de um carregamento equivalente uniformemente distribuído sobre a longarina. Esta aproximação é suficientemente precisa para os objetivos do dimensionamento. Nos casos de vãos curtos e carregamentos de alta magnitude, é recomendável fazer a análise de maneira exata, principalmente na verificação do cisalhamento.

Por fim, definido o espaçamento das longarinas ou transversinas, se o sistema for constituído somente por essas, tem-se o carregamento aplicado nas escoras. Com o pé-direito já estabelecido pelo projeto estrutural procede-se ao cálculo da seção resistente dos suportes. 
Atualmente, com o emprego de novos materiais, como por exemplo, vigas mistas (aço e madeira) substituindo as transversinas e longarinas de madeira, e as escoras metálicas, ou até mesmo as torres metálicas, substituindo os pontaletes de madeira, estes não mudam os roteiros de cálculos definidos anteriormente. Sendo válido para qualquer tipo de material, bastando-se para isso apenas substituir as características intrínsecas do novo material.

\subsubsection{Subsistema de fôrmas para vigas}

As fôrmas para as vigas devem suportar carga vertical proveniente do peso próprio do concreto, do aço e das fôrmas como ação permanente, mais as ações variáveis consideradas para as lajes, estas suportadas pelas chapas compensadas e transmitidas para as faces laterais das vigas, como também o empuxo lateral do concreto fresco, calculado segundo a Teoria de Mohr-Coulomb (ver item 4.7). A FIGURA 5.5b ilustra o detalhe de encontro entre o assoalho da laje e a face lateral de uma viga.

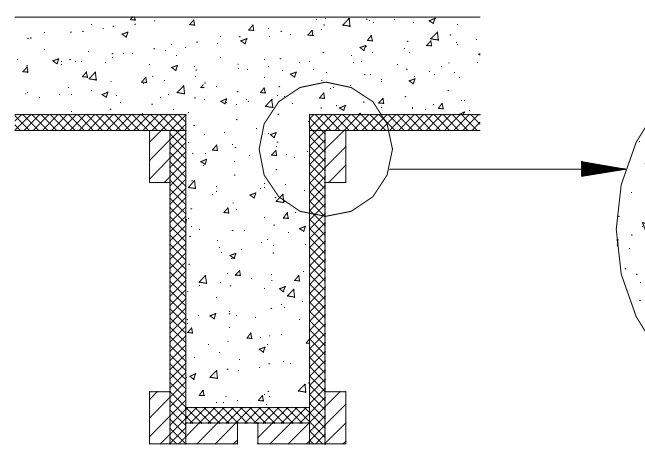

(a)

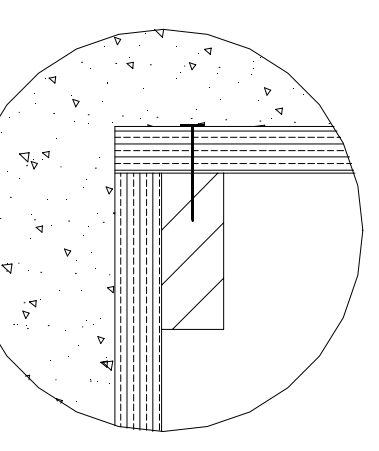

(b)

FIGURA 5.5 - (a) Seção transversal de uma viga com a fôrma e (b) encontro da fôrma da laje com a face lateral da fôrma da viga

Devido às solicitações verticais e horizontais, as laterais tendem a ser exigidas por esforços representados pela FIGURA 5.6, em seguida. 


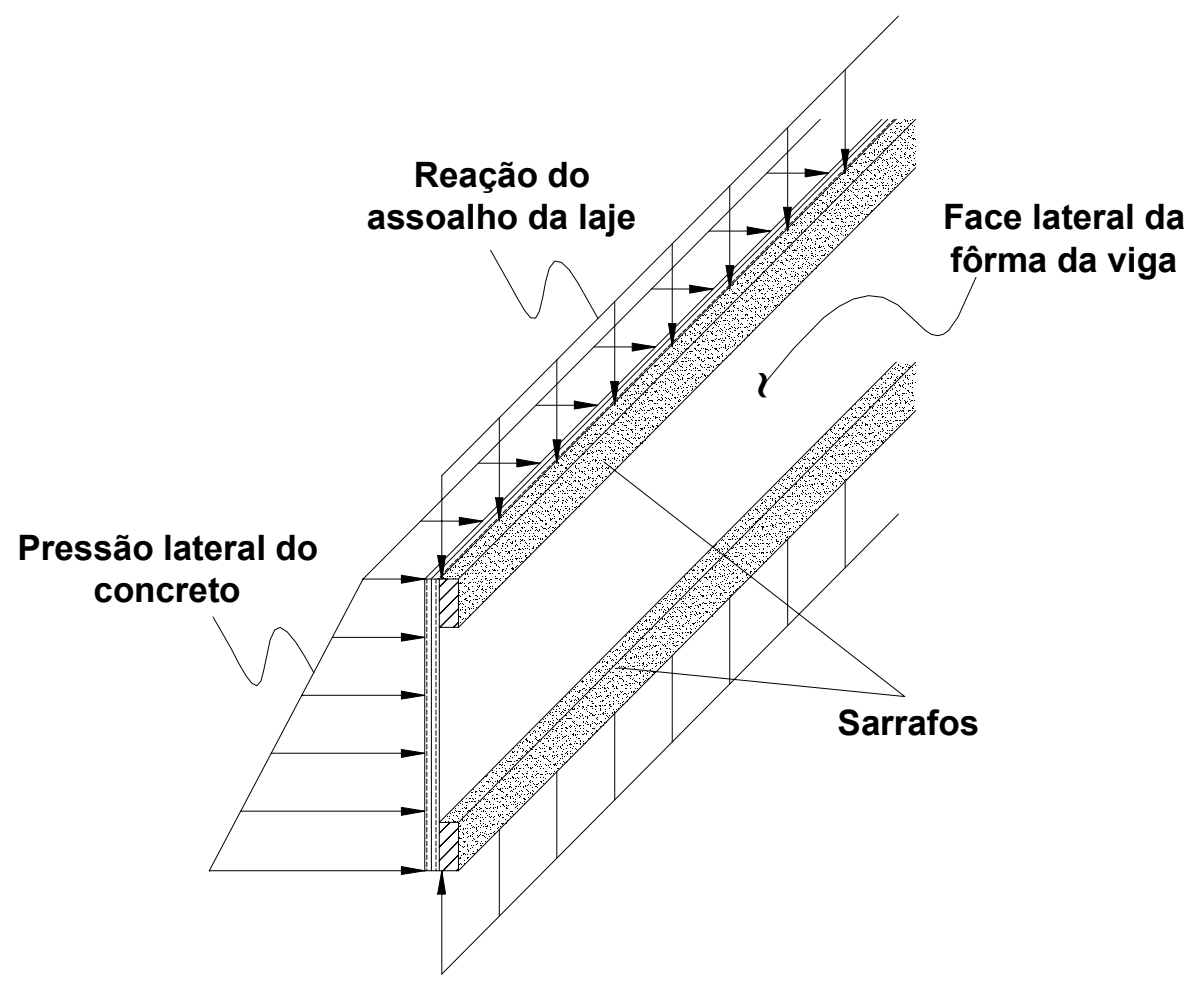

FIGURA 5.6 - Ações a que estão submetidas as faces laterais das fôrmas de vigas

Esses esforços poderão gerar deformações longitudinais e transversais, as primeiras contidas por elementos transversais (gastalhos e/ou garfos, por exemplo) devidamente calculados, e as últimas por elementos de rigidez longitudinais (sarrafos) fixados nas faces laterais das vigas, a depender da altura da mesma.

$\mathrm{Na}$ realidade, então, têm-se as faces laterais das vigas submetidas a esforços de flexocompressão. Entretanto, nos cálculos serão desprezados as ações de compressão provenientes do assoalho da laje pois, em casos correntes, na pior situação de carregamento, o valor desta carga é inferior a $3 \%$ da carga crítica da face lateral da viga, analisando-a como uma barra, e os esforços de flexão gerados com a consideração deste carregamento são da mesma ordem, ou seja, desprezíveis.

Outro elemento solicitado no subsistema de fôrmas para vigas é o painel de fundo da fôrma para as vigas. Para esse deve ser feita a consideração de todas as ações e, então, procede-se o dimensionamento. Assim como nas faces laterais, os esforços nas fôrmas do fundo das vigas geram deformações longitudinais e transversais, que serão contidas pelas escoras (garfos, pontaletes, etc.) e por elementos de rigidez longitudinais (sarrafos) fixados nas fôrmas de fundo das vigas, a depender da largura da mesma. 
Definidas as ações atuantes no subsistema de fôrmas para vigas, o projeto segue a mesma orientação adotada para o caso das lajes. Para os diferentes componentes das fôrmas são feitas análises dos seus comportamentos quanto à flexão, flecha máxima e cisalhamento. Desta forma pode-se definir as faces laterais da viga, bem como o painel de fundo. Com o espaçamento das escoras procede-se ao cálculo das mesmas.

Definidos o molde e a estrutura do molde, ou seja, a distância entre os garfos (ou pontaletes) e os gastalhos (quando houver), estes devem ser dimensionados para suportar a pressão lateral do concreto e as cargas verticais, considerando-se a seção composta no caso dos garfos.

\subsubsection{Subsistema de fôrmas para pilares}

As fôrmas para pilares apresentam várias soluções, quanto à estruturação do molde, dentre elas pode-se mencionar as chapas de madeira compensada sarrafeada horizontalmente com travamento através de guias de amarração verticais (duplo sarrafo); as chapas de madeira compensada sarrafeada verticalmente com travamento através de gravatas de amarração horizontais; as chapas de madeira compensada sem sarrafeamento, travadas através de guias de amarração verticais, e as chapas de madeira compensada sem sarrafeamento, travadas através de gravatas de amarração horizontais.

Com o sarrafeamento, os painéis de chapa de madeira compensada ficam enrijecidos, podendo optar-se pelo uso da chapa de compensado com espessura de $12 \mathrm{~mm}$. Sem o sarrafeamento fica obrigatório o uso da chapa compensada com espessura de no mínimo $18 \mathrm{~mm}$, embora o cálculo permita uma espessura menor. Esta recomendação tem como finalidade evitar problemas de execução.

No projeto das fôrmas dos pilares, inicialmente deve-se determinar a pressão lateral exercida pelo concreto. Assim como nas vigas, para o cálculo da pressão será utilizada a formulação baseada na Teoria de Mohr-Coulomb (ver item 4.7).

Definida a curva de pressão lateral do concreto, de acordo o molde e a estruturação estabelecida, determinam-se os espaçamentos dos elementos (sarrafos, guias ou gravatas de amarração e tensores) que melhor atendam às solicitações. A verificação dos diferentes elementos deve ser feita segundo os 
critérios de ruptura na flexão e no cisalhamento, bem como quanto a flecha máxima.

A mudança dos espaçamentos dos elementos pode variar de acordo com o empuxo do concreto, mas também deve satisfazer condições de facilitar as operações de montagem no campo.

\subsection{Exemplo comentado de dimensionamento dos subsistemas que compõem o sistema de fôrmas}

Todas as orientações apresentadas nos itens anteriores ficam mais claras quando aplicadas a exemplos práticos. Portanto, a seguir é apresentado um exemplo de dimensionamento de fôrmas das lajes, vigas e pilares para a estrutura mostrada na FIGURA 5.7. Neste exemplo, cada passagem do dimensionamento é comentada, explicitando melhor os procedimentos ora apresentados.

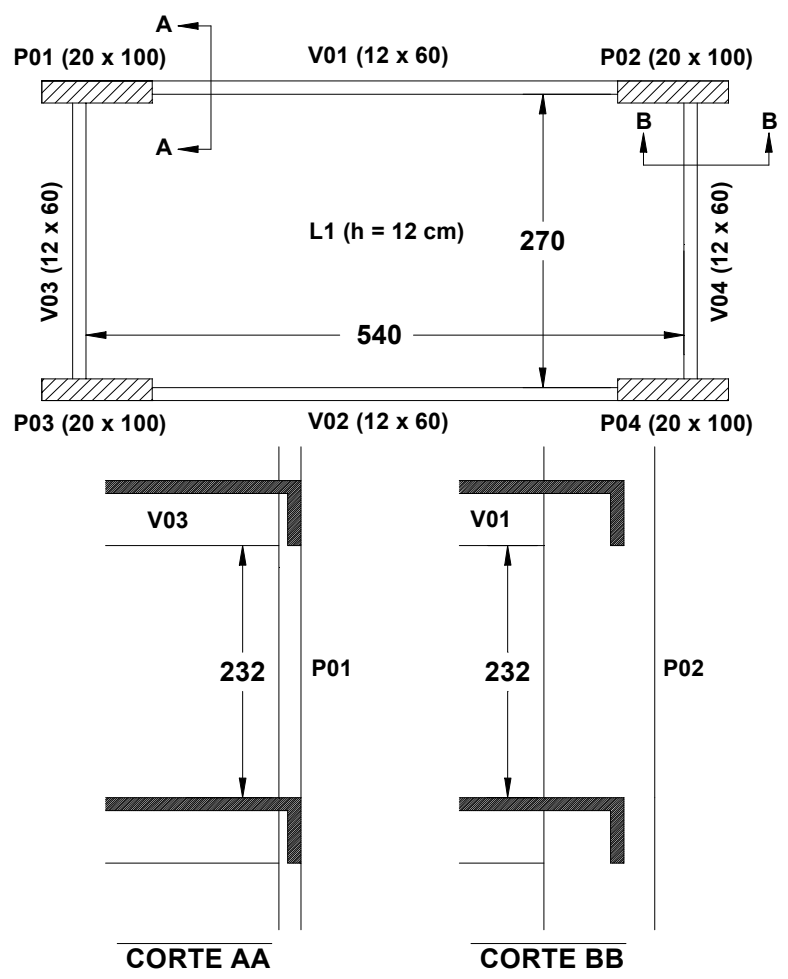

FIGURA 5.7 - Planta baixa e cortes da estrutura a ser dimensionada as fôrmas (medidas em $\mathrm{cm}$ ) 


\subsubsection{Subsistema de fôrmas para lajes}

O primeiro passo a ser seguido pelo projetista de fôrmas é a definição das ações que estão atuando na laje. Definida as ações deve-se especificar os materiais que serão utilizados no molde e na estrutura do molde da fôrma: tipo de chapa de madeira compensada, espessura, resistências, madeira da estrutura do molde e suas resistências, etc. É importante ao definir esses materiais, ter certeza de que os mesmos serão utilizados na fabricação das fôrmas.

Para a laje da estrutura do exemplo (FIGURA 5.7), de $12 \mathrm{~cm}$ de espessura, têm-se para as ações permanentes (considerando para o concreto fresco um peso específico de $25 \mathrm{kN} / \mathrm{m}^{3}$ ) o valor de:

$$
\begin{array}{ll}
Q_{G, k 1}=25 \times 0,12=3,00 \mathrm{kN} / \mathrm{m}^{2} & \text { (Peso do concreto fresco) } \\
Q_{\mathrm{G}, \mathrm{k} 2}=0,50 \mathrm{kN} / \mathrm{m}^{2} & \text { (Peso próprio das fôrmas) } \\
\mathrm{Q}_{\mathrm{G}, \mathrm{k}}=3,00+0,50=3,50 \mathrm{kN} / \mathrm{m}^{2} &
\end{array}
$$

e para as ações variáveis têm-se:

$$
Q_{Q, k}=1,00 \mathrm{kN} / \mathrm{m}^{2}
$$

resultando

$$
\begin{aligned}
& Q_{k}=Q_{G, k}+Q_{Q, k} \\
& Q_{k}=3,50+1,00=4,50 \mathrm{kN} / \mathrm{m}^{2}
\end{aligned}
$$

Será adotado, por razões comerciais, chapa de madeira compensada plastificada com dimensões de $122 \mathrm{~cm}$ de largura por $244 \mathrm{~cm}$ de comprimento e 18 $\mathrm{mm}$ de espessura (fundamentado no que foi comentado no item 5.8.3). A TABELA 5.11 apresenta as especificações da chapa de madeira compensada utilizada nesse exemplo. 
TABELA 5.11 - Especificações da chapa de madeira compensada

\begin{tabular}{|c|c|}
\hline Espessura nominal (mm) / Número de lâminas & $18 / 11$ \\
\hline Resistência característica à compressão na flexão & 55 (direção paralela) \\
\hline (MPa) & 45 (direção perpendicular) \\
\hline Módulo de elasticidade médio & 6000 (direção paralela) \\
\hline (MPa) & 5500 (direção perpendicular) \\
\hline Resistência característica ao cisalhamento (MPa) & 1,5 \\
\hline Umidade de equilíbrio (\%) & 12 \\
\hline Bitola média para efeito de cálculo $(\mathrm{mm})$ & 18 \\
\hline Módulo de inércia I - faixa de $1{\mathrm{~m}\left(\mathrm{~m}^{4}\right)}^{4}$ & $4,86.10^{-7}$ \\
\hline Módulo de resistência $\mathrm{W}$ - faixa de $1 \mathrm{~m} \mathrm{( \textrm {m } ^ { 3 } )}$ & $5,4 \cdot 10^{-5}$ \\
\hline Umidade de equilíbrio (\%) & 12 \\
\hline
\end{tabular}

Para a estrutura do molde será utilizada a madeira dicotiledônea E. Grandis (Eucalyptus grandis) com as seguintes características (TABELA 5.12):

TABELA 5.12 - Especificações da Madeira E. Grandis

\begin{tabular}{c|c}
\hline $\begin{array}{c}\text { Resistência característica à compressão paralela às } \\
\text { fibras (MPa) }\end{array}$ & 40 \\
\hline $\begin{array}{c}\text { Módulo de elasticidade médio paralelo às fibras } \\
(\mathrm{MPa})\end{array}$ & 12000 \\
\hline Resistência característica ao cisalhamento (MPa) & 7 \\
\hline Umidade de equilíbrio (\%) & 12 \\
\hline
\end{tabular}

Após a definição das ações e das características dos materiais, procede-se a disposição das chapas na laje, de maneira que se tenha o melhor aproveitamento possível, bem como maior facilidade na desmoldagem. A FIGURA 5.8 ilustra a disposição final das chapas na laje. 


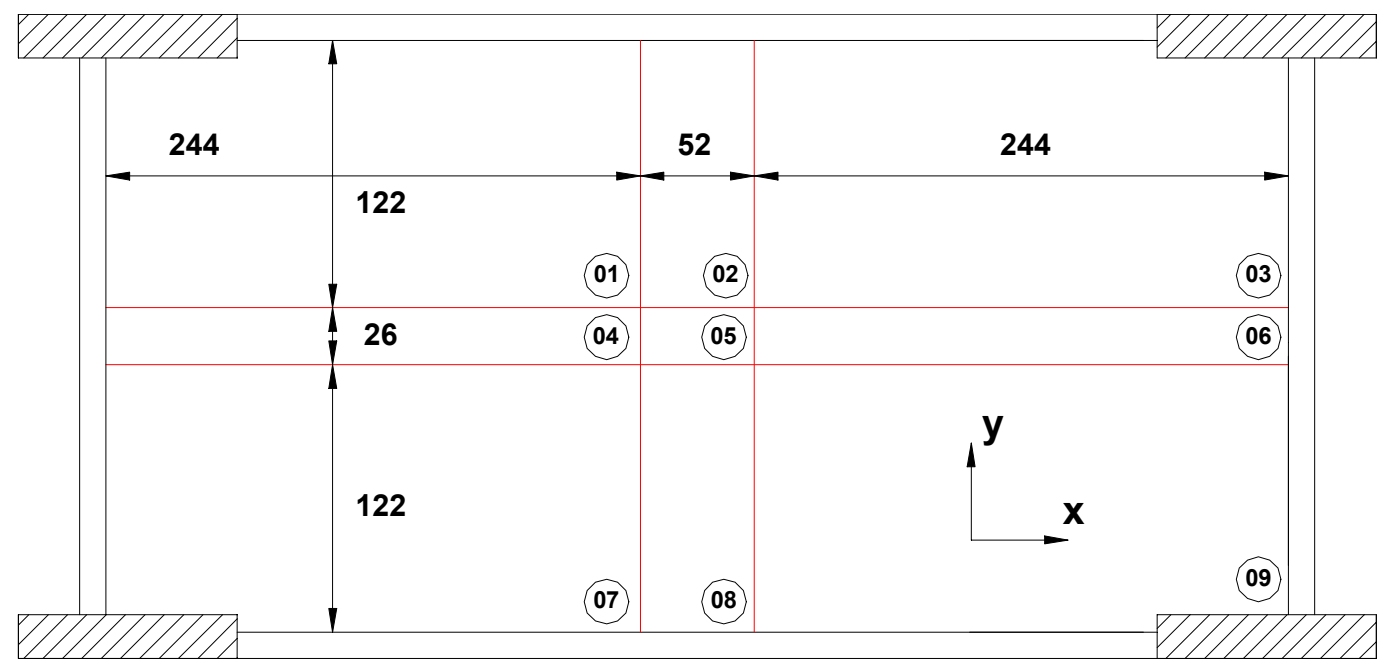

FIGURA 5.8 - Arranjo das chapas de madeira compensada na laje (medidas em $\mathrm{cm}$ )

As faixas centrais poderão ser utilizadas para o reescoramento, bem como a chapa $\mathrm{n}^{\circ}$. 05 pode ser utilizada para o início da desmoldagem, por ser esta a de menores dimensões, esses assuntos serão melhor tratados no Capítulo 6.

É importante deixar claro que só se pode pensar em otimização no corte das chapas, quando se analisa todo o sistema de fôrmas, não o subsistema isolado.

Com a definição do arranjo das chapas na laje faz-se o dimensionamento das mesmas, definindo o espaçamento das transversinas. No cálculo das chapas de madeira compensada a direção da grã das lâminas externas será considerada paralela na direção do eixo x (FIGURA 5.8), para todas as chapas. Para os projetistas de fôrmas não experientes esse cálculo pode se fazer de maneira interativa.

Para as transversinas utilizou-se peças de madeira (E. Grandis) com seção transversal $7 \mathrm{~cm} \times 7 \mathrm{~cm}$. Após algumas tentativas o autor chegou a seguinte disposição (FIGURA 5.9) para as chapas de $n^{\circ s}$. 01, 03, 04, 06, 07 e 09 :

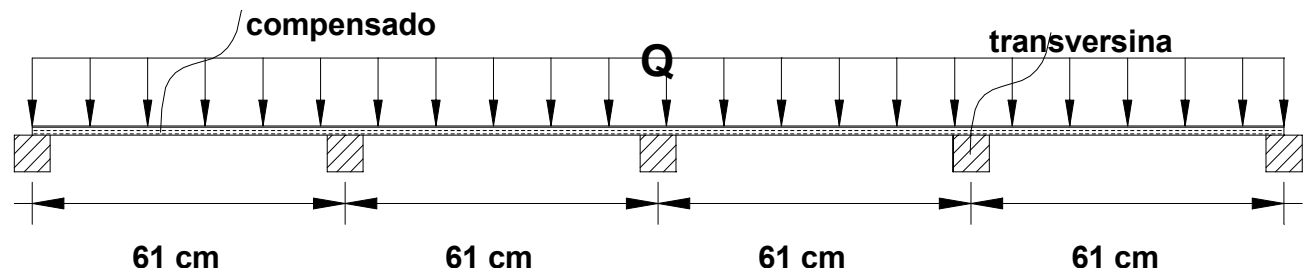

FIGURA 5.9 - Disposição das transversinas nas chapas de $n^{0 s} .01,03,04,06,07$ e 
Resultando no esquema estático definido pela FIGURA 5.10, em seguida:



FIGURA 5.10 - Esquema estático das chapas de ${ }^{\text {os }} .01,03,04,06,07$ e 09

Antes de partir para o cálculo propriamente dito torna-se necessário definir os coeficientes $\mathrm{K}_{\mathrm{M}}, \mathrm{K}_{\mathrm{V}}$ e $\mathrm{K}_{\mathrm{f}}$ referentes ao momento fletor máximo, a força cortante máxima e a flecha máxima, função do sistema estático adotado, que são, respectivamente 3/28, 8/7 e 17/2688 (4 vãos, TABELA 5.10). Como também, o coeficiente de majoração das ações $(\gamma=1,4)$, os coeficientes de minoração dos materiais: no estado limite último decorrente de tensões de compressão $(\gamma=1,4)$, das tensões de cisalhamento $(\gamma=1,8)$ e no estado limite de utilização $(\gamma=1,0)$, e finalmente, os coeficientes de modificação: $k_{\bmod , 1}=1,0, k_{\bmod , 2}=1,0$ e $k_{\bmod , 3}=1,0$ para as chapas de madeira compensada $e, k_{\text {mod, } 1}=1,0, k_{\text {mod, } 2}=1,0$ e $k_{\bmod , 3}=0,8$ para a madeira E. Grandis.

Na situação estática da FIGURA 5.10, utilizando as EQUAÇÕES 5.36, 5.37 e 5.38, têm-se:

$$
\begin{aligned}
& f_{\text {máx }}=(17 / 2688) \frac{4,50 \cdot 0,61^{4}}{6000000 \cdot 4,86 \cdot 10^{-7}}=1,35 \cdot 10^{-3} \mathrm{~m}<\frac{\mathrm{L}}{350}\left(1,74 \cdot 10^{-3} \mathrm{~m}\right) \\
& \sigma_{\mathrm{c} 0, \mathrm{~d}}=\frac{6 \cdot(3 / 28) \cdot 6,3 \cdot 0,61^{2}}{1 \cdot 0,018^{2}}=4651,25 \mathrm{kN} / \mathrm{m}^{2}<\mathrm{f}_{\mathrm{c} 0, \mathrm{~d}}\left(39285,71 \mathrm{kN} / \mathrm{m}^{2}\right) \\
& \tau_{\mathrm{d}}=\frac{3}{2} \frac{(8 / 7) \cdot 6,3 \cdot 0,61}{1 \cdot 0,018}=366 \mathrm{kN}<\mathrm{f}_{\mathrm{v}, \mathrm{d}}(833,33 \mathrm{kN})
\end{aligned}
$$

Para as chapas de $n^{\text {os }}$. 02, 05 e 08, chegou-se a seguinte disposição, ilustrada na FIGURA 5.11 em seguida: 


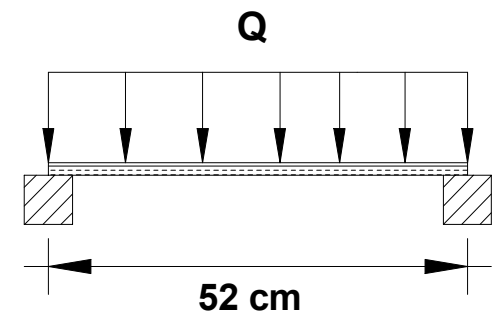

(a)

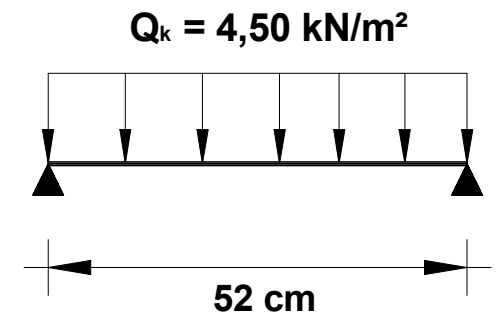

(b)

FIGURA 5.11 - (a) Disposição das transversinas e (b) esquema estático das chapas de $n^{\text {os }}$.02, 05 e 08

Nessa situação estática (FIGURA 5.11b), utilizando as mesmas expressões (EQUAÇÕES 5.36, 5.37 e 5.38), têm-se:

$f_{\text {máx }}=(5 / 384) \frac{4,50 \cdot 0,52^{4}}{6000000 \cdot 4,86 \cdot 10^{-7}}=1,47 \cdot 10^{-3} \mathrm{~m}<\frac{\mathrm{L}}{350}\left(1,49 \cdot 10^{-3} \mathrm{~m}\right)$

$\sigma_{\mathrm{c} 0, \mathrm{~d}}=\frac{6 \cdot(1 / 8) \cdot 6,3 \cdot 0,52^{2}}{1 \cdot 0,018^{2}}=3943,33 \mathrm{kN} / \mathrm{m}^{2}<\mathrm{f}_{\mathrm{co,d}}\left(39285,71 \mathrm{kN} / \mathrm{m}^{2}\right)$

$\tau_{d}=\frac{3}{2} \frac{(1 / 2) \cdot 6,3 \cdot 0,52}{1 \cdot 0,018}=136,5 \mathrm{kN}<\mathrm{f}_{\mathrm{v}, \mathrm{d}}(833,33 \mathrm{kN})$

A FIGURA 5.12, em seguida, ilustra a disposição final das transversinas:

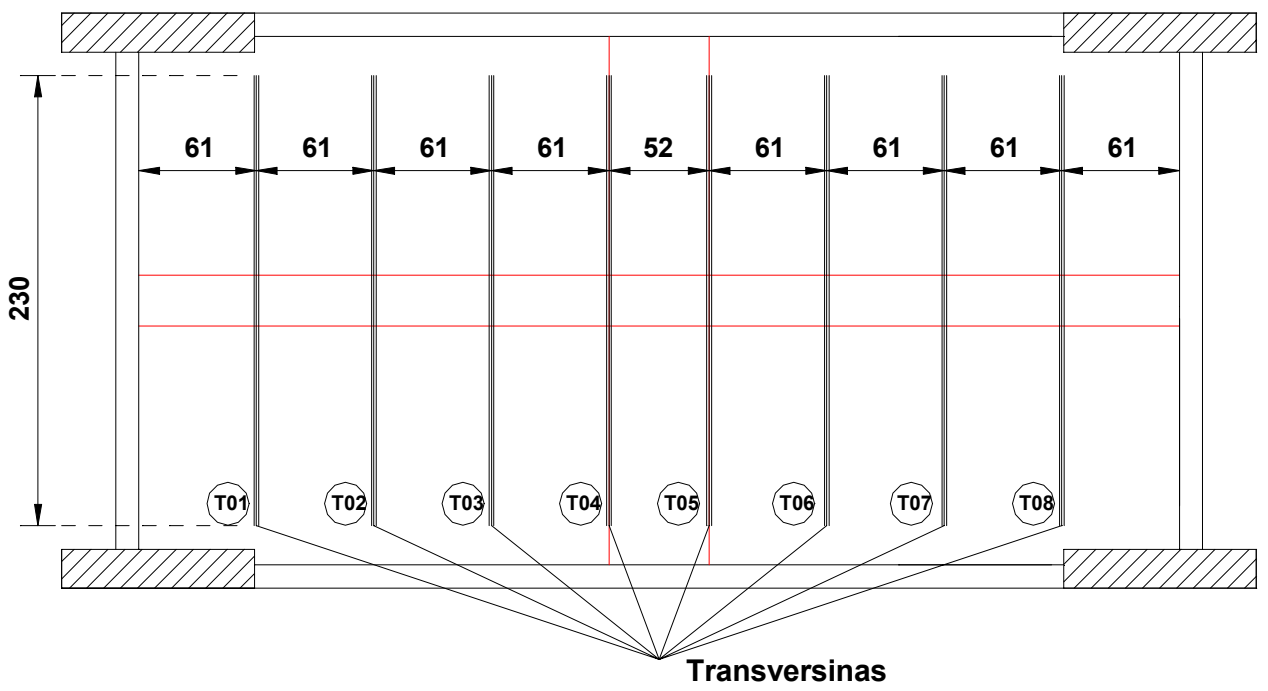

FIGURA 5.12 - Arranjo das transversinas que dão apoio às chapas de madeira compensada (medidas em $\mathrm{cm}$ ) 
No anexo está apresentado uma formulação para elaboração de ábacos que auxiliarão no dimensionamento das chapas de madeira compensada, com diferentes resistências, diferentes espessuras de chapas, dependendo do modelo estático.

Em capítulo à parte (Capítulo 6 - Disposições Construtivas) será dado ênfase a detalhes construtivos, e grande importância na fase de concepção do projeto, como por exemplo, a definição do comprimento das transversinas e a possibilidade de se apoiar as transversinas sobre guias que estão sendo suportadas pelos garfos das fôrmas das vigas (ver FIGURA 6.3).

Definido o arranjo das transversinas faz-se a verificação das mesmas quanto aos estados limites último e de utilização, definindo o espaçamento das longarinas.

Para as transversinas T01, T03, T06 e T08 têm-se as chapas de madeira compensada transmitindo uma reação $\mathrm{Q}_{\mathrm{T}, \mathrm{k}}$ (valor característico) dada por (4 vãos, TABELA 5.10):

$\mathrm{Q}_{\mathrm{T}, \mathrm{k}}=\frac{8 \mathrm{Q}_{\mathrm{k}} \mathrm{L}}{7}=\frac{8 \cdot 4,5 \cdot 0,61}{7}=3,14 \mathrm{kN} / \mathrm{m}$

Para as transversinas T02 e T07, têm-se (4 vãos, TABELA 5.10):

$Q_{T, k}=\frac{13 Q_{k} L}{14}=\frac{13 \cdot 4,5 \cdot 0,61}{14}=2,55 \mathrm{kN} / \mathrm{m}$

E, para as transversinas T04 e T05, têm-se (4 vãos e 1 vão, TABELA 5.10):

$Q_{T, k}=\frac{11 Q_{k} L}{28}+\frac{Q^{\prime}}{2}=\frac{11 \cdot 4,5 \cdot 0,61}{28}+\frac{4,5 \cdot 0,52}{2}=2,25 \mathrm{kN} / \mathrm{m}$

A FIGURA 5.13 apresenta o esquema estático que melhor se adequa as transversinas. 




FIGURA 5.13 - Esquema estático para as transversinas

A solução mais conveniente será uma viga bi-apoiada com balanços em suas extremidades. Até porque o comprimento das transversinas passa a ser um fator limitante, onde se permite chegar, em casos excepcionais, até 4,00 m, devido ao empenamento que as peças de madeira com grandes comprimentos apresentam e, no caso de peças mistas ou de aço, pelo seu peso durante a montagem.

A relação mais otimizada entre o comprimento em balanço a e o vão entre os apoios $b$, é obtido fazendo a flecha na extremidade do balanço igual a no meio do vão, ficando:

$\mathrm{b}=\frac{\mathrm{L}}{1,806} \quad$ e $\quad \mathrm{a}=\frac{\mathrm{L}-\mathrm{b}}{2}$

De acordo com as relações acima (EQUAÇÃO 5.51) e com o comprimento da transversina $\mathrm{L}=2,30 \mathrm{~m}$ (FIGURA 5.12), os valores de $\mathrm{a}$ e $\mathrm{b}$ são, respectivamente, $0,50 \mathrm{~m}$ e 1,30 $\mathrm{m}$ (ver FIGURA 5.13).

Sendo as expressões da flecha no meio do vão (já que a flecha na extremidade do balanço é igual a no meio do vão), do momento máximo e do cortante máximo, dadas por:

$f_{\text {máx }}=\frac{Q b^{2}}{48 E I}\left(\frac{5}{8} b^{2}-3 a^{2}\right)$

$M_{\text {máx }}=\frac{Q_{d}}{2}\left(\frac{b^{2}}{4}-a^{2}\right)$ (meio do vão entre apoios) 
$V_{\text {máx }}=\frac{Q_{d} b}{2}$

Adotando para a transversina dimensões comerciais, $7 \mathrm{~cm} \times 7 \mathrm{~cm}$, com características da madeira E. Grandis já apresentada, verifica-se a mesma para a maior solicitação $Q_{T, k}=3,14$ kN/m (EQUAÇÃO 5.48).

$f_{\text {máx }}=\frac{3,14 \cdot 1,30^{2}}{48 \cdot 9,6 \cdot 10^{6} \cdot 2,001 \cdot 10^{-6}}\left(\frac{5}{8} 1,30^{2}-3 \cdot 0,50^{2}\right)$

$f_{\text {máx }}=1,76 \cdot 10^{-3} \mathrm{~m}<\frac{\mathrm{L}_{\mathrm{m}}}{350}\left(3,71 \cdot 10^{-3} \mathrm{~m}\right)$ e $\frac{\mathrm{L}_{\text {bal }}}{175}\left(2,86 \cdot 10^{-3} \mathrm{~m}\right)$

$M_{\text {máx }}=\frac{4,39}{2}\left(\frac{1,30^{2}}{4}-0,50^{2}\right)=0,38 \mathrm{kN} \cdot \mathrm{m}$

$\mathrm{V}_{\text {máx }}=\frac{4,39 \cdot 1,30}{2}=2,85 \mathrm{kN}$

$\sigma_{\mathrm{c} 0, \mathrm{~d}}=\frac{6 \mathrm{M}_{\text {máx }}}{\mathrm{h}^{3}}=\frac{6 \cdot 0,38}{0,07^{3}}=6647,23 \mathrm{kN} / \mathrm{m}^{2}<\mathrm{f}_{\mathrm{c} 0, \mathrm{~d}}\left(22857,14 \mathrm{kN} / \mathrm{m}^{2}\right)$

$\tau_{\mathrm{d}}=\frac{3}{2} \frac{\mathrm{V}_{\text {máx }}}{\mathrm{h}^{2}}=\frac{3}{2} \frac{2,85}{0,07^{2}}=872,45 \mathrm{kN}<\mathrm{f}_{\mathrm{v}, \mathrm{d}}(3111,11 \mathrm{kN})$

A FIGURA 5.14, em seguida, ilustra a disposição final das longarinas: 


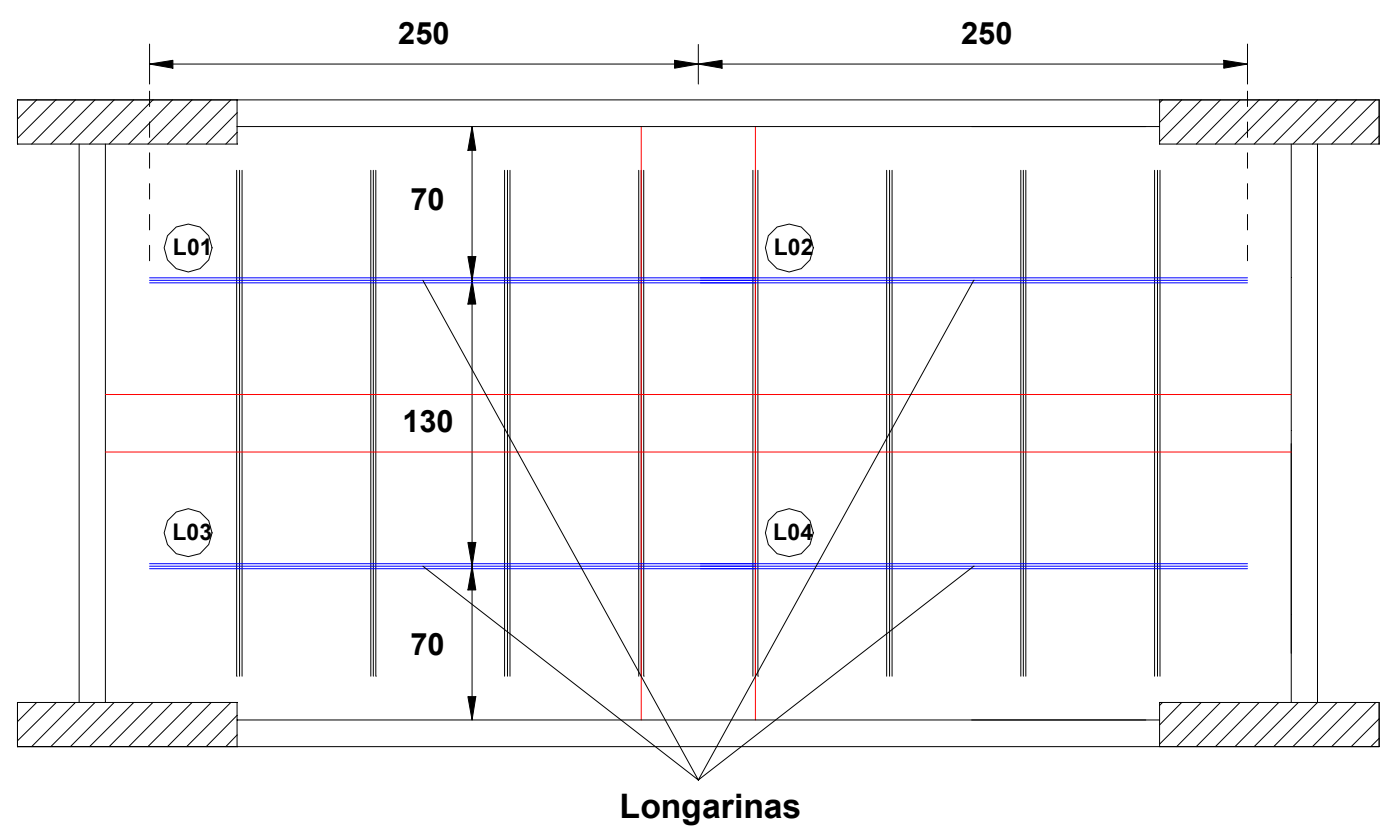

FIGURA 5.14 - Arranjo das longarinas que dão apoio às transversinas

(medidas em cm)

Da mesma forma, definido o arranjo das longarinas faz-se a verificação das mesmas quanto aos estados limites último e de utilização, definindo o espaçamento das escoras.

Nas longarinas o procedimento é semelhante ao das transversinas, será adotado o mesmo esquema estático (viga bi-apoiada com as extremidades em balanço, ver FIGURA 5.13), entretanto adota-se algumas simplificações. Como pode-se verificar o carregamento efetivo destes componentes (longarinas) é constituído por uma série de cargas concentradas nas posições de apoio das transversinas. a primeira simplificação que se pretende aplicar é a adoção da maior das reações que as transversinas transmitem às longarinas, ou seja, a transversina mais solicitada (T01, T03, T06 ou T08). Daí parte-se para a segunda simplificação, que é a adoção de um carregamento equivalente distribuído sobre a longarina. A FIGURA 5.15, em seguida, ilustra a situação real, bem como, as duas simplificações para a longarina L02 (ou L04). As longarinas foram compostas por 2 peças de madeira com seção transversal de $2,5 \mathrm{~cm} \times 15 \mathrm{~cm}$, espaçadas de $7,5 \mathrm{~cm}$. 
Capítulo 5 - Dimensionamento das Fôrmas

105

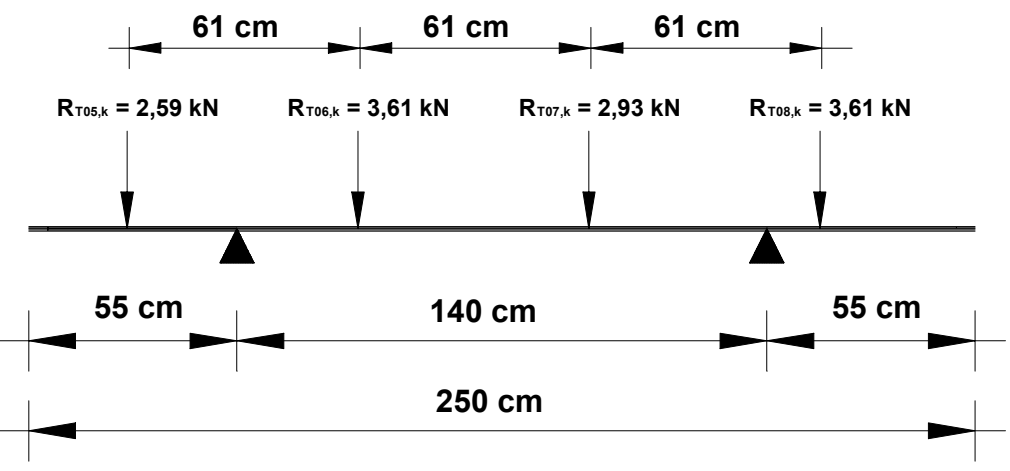

(a)



(b)

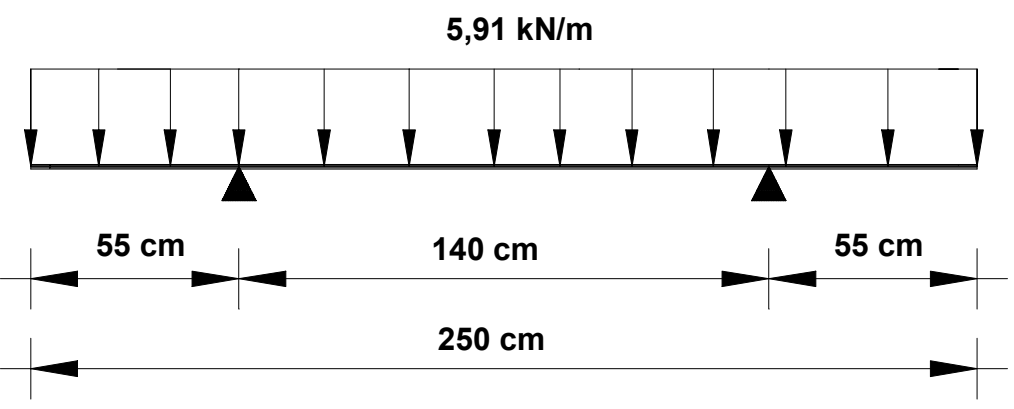

(c)

FIGURA 5.15 - Modelos estático da (a) situação real, (b) com a primeira simplificação e (c) com a segunda simplificação

A TABELA 5.13, em seguida, mostra os valores máximos do momento e cortante para as três situações, como também, as flechas na extremidade do balanço e no meio do vão entre apoios. 
TABELA 5.13 - Momento máximo, cortante máximo e flechas para os três esquemas estático

\begin{tabular}{l|c|c|c|c}
\hline \multirow{2}{*}{$\begin{array}{c}\text { Esquema } \\
\text { Estático }\end{array}$} & $\begin{array}{c}\text { Momento } \\
\text { máximo* } \\
(\mathrm{kN} . \mathrm{m})\end{array}$ & $\begin{array}{c}\text { Cortante } \\
\text { máximo* }\end{array}$ & $\begin{array}{c}\text { Flecha meio do } \\
\text { vão }(\mathrm{mm})\end{array}$ & $\begin{array}{c}\text { Flecha no } \\
\text { balanço }(\mathrm{mm})\end{array}$ \\
\cline { 4 - 5 } & $(\mathrm{kN})$ & \multicolumn{2}{|c}{ Flecha admissível } \\
\cline { 4 - 5 } & 0,78 & 3,90 & $\pm 4,00 \mathrm{~mm}$ & $\pm 3,14 \mathrm{~mm}$ \\
\hline Situação real & 1,08 & 4,48 & 0,755 & $-0,534$ \\
\hline $1^{\text {a Simplificação }}$ & 0,90 & 4,14 & 0,568 & $-0,769$ \\
\hline 2 & & &
\end{tabular}

Diante dos resultados percebe-se que a utilização das simplificações validam o terceiro esquema estático (FIGURA 5.15c), podendo ser usado por sua simplicidade e precisão diante daquela que se considera a situação real.

A FIGURA 5.16, em seguida, ilustra a disposição das escoras:

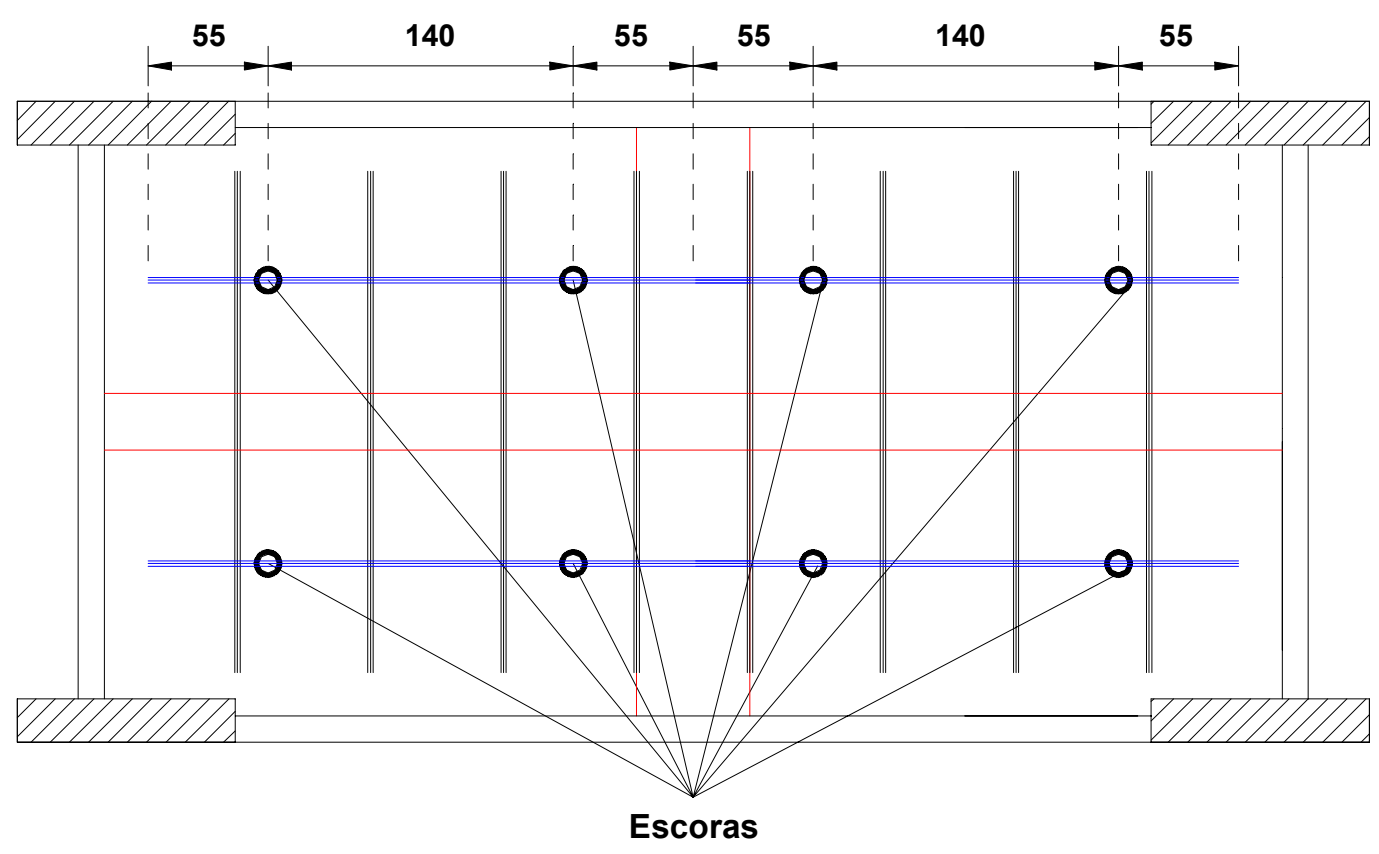

FIGURA 5.16 - Arranjo das escoras que dão suporte às longarinas (medidas em $\mathrm{cm}$ )

Definida a posição das escoras, resta fazer o dimensionamento das mesmas, para que o subsistema de fôrmas para lajes esteja finalizado. 
Para as escoras será adotado um pontalete de madeira (E. Grandis) com seção transversal quadrada $(7 \mathrm{~cm} \times 7 \mathrm{~cm})$, por ser esta as dimensões mais encontradas comercialmente.

Através do esquema estático da FIGURA 5.15c tem-se como reação das longarinas nas escoras a carga $N_{k}=7,39 \mathrm{kN}$. Com os devidos descontos tem-se para a escora um comprimento $L_{0}=2,53 \mathrm{~m}$ (FIGURA 5.17).

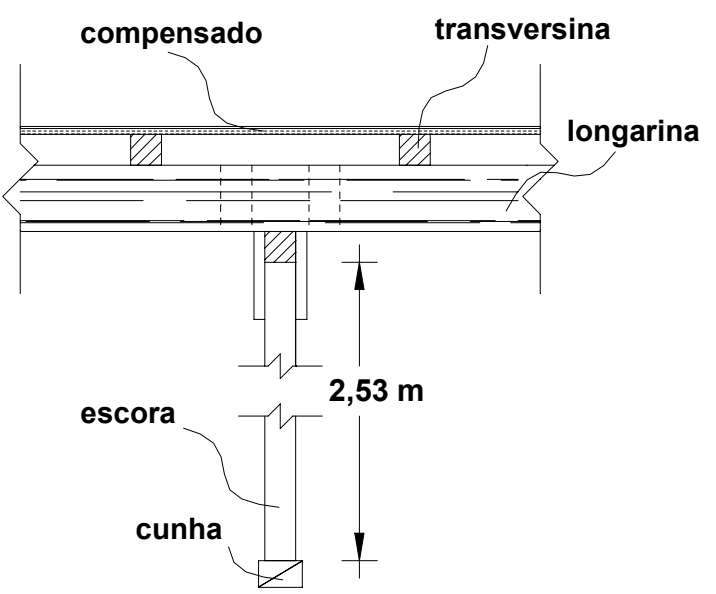

FIGURA 5.17 - Escora que dá suporte à longarina

Considerando as propriedades da madeira E. Grandis já apresentadas e as características da peça, tem-se como índice de esbeltez o valor de:

$$
\lambda=\frac{2,53}{\sqrt{\frac{2,001 \cdot 10^{-6}}{0,0049}}}=125,21
$$

O momento fletor $M_{d}$ que entra no cálculo do valor da tensão de compressão $\left(\sigma_{\mathrm{M}, \mathrm{d}}\right)$ deve ser calculado pela expressão:

$$
M_{d}=N_{d}\left(e_{a}+e_{c}\right)\left(\frac{F_{E}}{F_{E}-N_{d}}\right)
$$

sendo $F_{E}$ a carga crítica, expressa por: 
$F_{E}=\frac{\pi^{2} \cdot 9,6 \cdot 10^{6} \cdot 2,001 \cdot 10^{-6}}{2,53^{2}}=29,62 \mathrm{kN}$

$\mathrm{e}_{\mathrm{a}}$ a excentricidade acidental devida às imperfeições geométricas, dada por:

$e_{a}=\frac{2,53}{300}=0,0084 \mathrm{~m}$

e, $e_{c}$ a excentricidade suplementar de primeira ordem que representa a fluência da madeira, expressa por:

$$
\begin{aligned}
& e_{c}=\left(e_{a}\right)\left\{\left[\exp \left(\frac{\phi\left[\mathrm{N}_{\mathrm{gk}}+\left(\psi_{1}+\psi_{2}\right) \mathrm{N}_{\mathrm{qk}}\right]}{\mathrm{F}_{\mathrm{E}}-\left[\mathrm{N}_{\mathrm{gk}}+\left(\psi_{1}+\psi_{2}\right) \mathrm{N}_{\mathrm{qk}}\right]}\right)\right]-1\right\} \\
& \mathrm{e}_{\mathrm{c}}=(0,0084)\left\{\left[\exp \left(\frac{0,1[0,75 \cdot 7,39+(0,3+0,2) \cdot 0,25 \cdot 7,39]}{29,62-[0,75 \cdot 7,39+(0,3+0,2) \cdot 0,25 \cdot 7,39])}\right)\right]-1\right\} \\
& \mathrm{e}_{\mathrm{c}}=2,39 \cdot 10^{-4} \mathrm{~m}
\end{aligned}
$$

$\mathrm{Na}$ utilização da expressão anterior, para o cálculo da excentricidade suplementar (EQUAÇÃO 5.61), adotou-se para a carga permanente vertical $75 \%$ da total $\left(N_{k}=7,39 \mathrm{kN}\right)$, e para a acidental $25 \%$. Essas porcentagens expressam bem a realidade do carregamento.

O momento fletor $M_{d}$ (EQUAÇÃO 5.58) fica, então

$M_{d}=10,35 \cdot\left(0,0084+2,39 \cdot 10^{-4}\right)\left(\frac{29,62}{29,62-10,35}\right)=0,138 \mathrm{kN} \cdot \mathrm{m}$

Fazendo agora o momento fletor $M_{d}$ (EQUAÇÃO 5.58) sem a consideração da fluência, tem-se:

$$
M_{d}=10,35 \cdot(0,0084)\left(\frac{29,62}{29,62-10,35}\right)=0,134 \mathrm{kN} \cdot \mathrm{m}
$$


Percebe-se pois, que é insignificante a consideração da fluência, fato este já percebido pelo autor, já que se está tratando, quando muito, de um carregamento de curta duração, sendo desprezível daqui em diante.

Para as tensões devido à força normal e ao momento têm-se:

$\sigma_{\mathrm{N}, \mathrm{d}}=\frac{10,35}{0,07^{2}}=2112,24 \mathrm{kN} / \mathrm{m}^{2}$

$\sigma_{\mathrm{M}, \mathrm{d}}=\frac{6 \cdot 0,134}{0,07^{3}}=2344,02 \mathrm{kN} / \mathrm{m}^{2}$

A fim de respeitar a condição da EQUAÇÃO 5.18, tem-se:

$\frac{2112,24}{22857,14}+\frac{2344,02}{22857,14}=0,195<1$

Com isso chega-se a definição do subsistema de fôrmas para as lajes, deixando claro que a solução anteriormente concebida foi imparcialmente adotada pelo autor, podendo outras soluções serem utilizadas.

\subsubsection{Subsistema de fôrmas para vigas}

O cálculo do subsistema de fôrmas para vigas inicia-se pelo assoalho de fundo das vigas, assim como no assoalho das lajes, define-se as ações a que estão submetidas (Capítulo 3). De acordo com a FIGURA 5.7 tem-se para as viga V01 (= V02, V03 e V04) uma base de $12 \mathrm{~cm}$ de largura e altura de $60 \mathrm{~cm}$. Quantificando as ações, encontra-se:

$$
\begin{array}{ll}
Q_{\mathrm{G}, \mathrm{k} 1}=25 \times 0,60=15,00 \mathrm{kN} / \mathrm{m}^{2} & \text { (Peso do concreto fresco) } \\
Q_{\mathrm{G}, \mathrm{k} 2}=0,50 \mathrm{kN} / \mathrm{m}^{2} & \text { (Peso próprio das fôrmas) } \\
\mathrm{Q}_{\mathrm{G}, \mathrm{k} 3}=0,50 \mathrm{kN} / \mathrm{m}^{2} & \text { (Ações variáveis) } \\
Q_{\mathrm{G}, \mathrm{k}}=15,00+0,50+0,50=16,00 \mathrm{kN} / \mathrm{m}^{2} &
\end{array}
$$


Para o fundo da viga será adotada chapa de madeira compensada de 18 $\mathrm{mm}$ de espessura, estruturada por dois sarrafos de $2,5 \mathrm{~cm} \times 5,0 \mathrm{~cm}$. A FIGURA 5.18, em seguida, ilustra a situação.

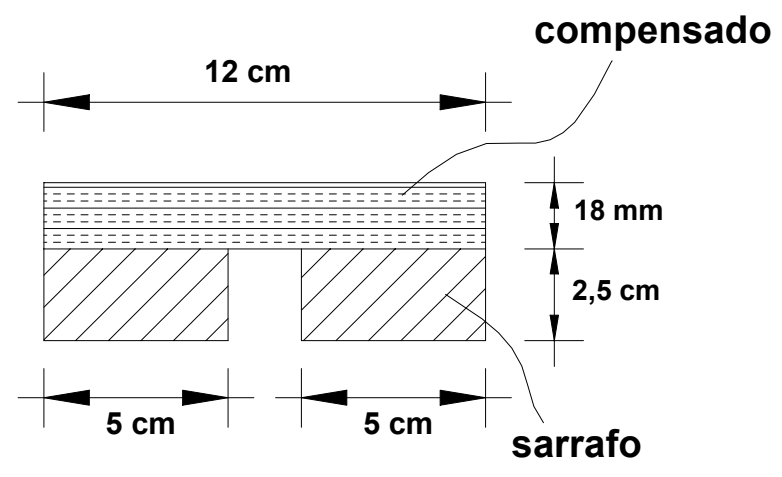

FIGURA 5.18 - Painel de fundo da fôrma da viga

São duas as deformações ocorridas no fundo das vigas, as longitudinais e as transversais, que serão contidas pelas escoras e pelos sarrafos, respectivamente. Para se proceder o cálculo do fundo das vigas, a seção transversal será homogeneizada para apenas um material (chapa de madeira compensada), em seguida o método é detalhado para a viga V01, ilustrado pela FIGURA 5.19.



FIGURA 5.19 - Homogeneização do painel de fundo da fôrma da viga

Inicialmente será verificado as tensões e a flecha na direção transversal, lembrando que o módulo de elasticidade nessa direção é $5500 \mathrm{MPa}$ e a resistência característica à compressão na flexão $45 \mathrm{MPa}$ (TABELA 5.11), por estar perpendicular à grã das lâminas externas. Para essa verificação o esquema estático será uma viga bi-apoiada com um vão de $7 \mathrm{~cm}$, entre os sarrafos. Utilizando as devidas expressões (EQUAÇÕES 5.36, 5.37 e 5.38), têm-se: 
$f_{\text {máx }}=(5 / 384) \frac{16,0 \cdot 0,07^{4}}{5500000 \cdot 4,86 \cdot 10^{-7}}=1,87 \cdot 10^{-6} \mathrm{~m}<\frac{\mathrm{L}}{350}\left(2 \cdot 10^{-4} \mathrm{~m}\right)$

$\sigma_{\mathrm{c} 0, \mathrm{~d}}=\frac{6 \cdot(1 / 8) \cdot 22,4 \cdot 0,07^{2}}{1 \cdot 0,018^{2}}=254,07 \mathrm{kN} / \mathrm{m}^{2}<\mathrm{f}_{\mathrm{c} 0, \mathrm{~d}}\left(32142,86 \mathrm{kN} / \mathrm{m}^{2}\right)$

$\tau_{\mathrm{d}}=\frac{3}{2} \frac{(1 / 2) \cdot 22,4 \cdot 0,07}{1 \cdot 0,018}=65,33 \mathrm{kN}<\mathrm{f}_{\mathrm{v}, \mathrm{d}}(833,33 \mathrm{kN})$

Analisando agora a direção longitudinal, tem-se para a homogeneização da seção:

$a=5 \cdot \frac{E_{\text {mad }}}{E_{\text {comp }}}=5 \cdot \frac{9,6 \cdot 10^{6}}{6,0 \cdot 10^{6}}=8 \mathrm{~cm}$

A distância da face inferior (do sarrafo) ao centro de gravidade fica:

c.g. $=\frac{2 \cdot 2,5 \cdot 8 \cdot 1,25+1,8 \cdot 12 \cdot 3,4}{2 \cdot 2,5 \cdot 8+1,8 \cdot 12}=2,004 \mathrm{~cm}$

Com isso o momento de inércia da peça de compensado equivalente é dado por:

$I_{\text {th }}=\left(\frac{12 \cdot 1,8^{3}}{12}+12 \cdot 1,8 \cdot 1,4^{2}\right)+\left(2 \cdot \frac{8 \cdot 2,5^{3}}{12}+2 \cdot 8 \cdot 2,5 \cdot 0,75^{2}\right)=91,5 \mathrm{~cm}^{4}$

A NBR 7190 (1997) prescreve que as peças compostas formando seção T, I ou caixão podem ser dimensionadas como peças maciças desde que o momento de inércia seja minorado para que seja levado em conta as deficiências nas ligações. Ou seja, o momento de inércia efetivo $\left(\mathrm{l}_{\mathrm{ef}}\right)$ deve ser expresso por:

$\mathrm{I}_{\mathrm{ef}}=\alpha_{\mathrm{r}} \cdot \mathrm{I}_{\mathrm{th}}$ 
onde $I_{\text {th }}$ é o momento de inércia da seção total da peça como se fosse maciça, sendo para seções $T \alpha_{r}=0,95$ e para seções I ou caixão $\alpha_{r}=0,85$. O momento de inércia (EQUAÇÃO 5.73) fica, pois:

$$
\mathrm{I}=0,95 \cdot 91,5=86,93 \mathrm{~cm}^{4}
$$

Através da análise inicialmente feita pelo autor, verificou-se que a condição estática com 4 vãos $\left(K_{f}=17 / 2688, K_{M}=3 / 28\right.$ e $K_{V}=17 / 28$, TABELA 5.10) seria apropriada. Da mesma maneira, utilizando as devidas expressões (EQUAÇÕES 4.36, 4.9 e 4.12, respectivamente) para verificar a direção longitudinal, têm-se:

$$
\begin{aligned}
& f_{\text {máx }}=(17 / 2688) \frac{0,12 \cdot 16,0 \cdot 1,05^{4}}{6000000 \cdot 8,69 \cdot 10^{-7}}=2,83 \cdot 10^{-3} \mathrm{~m}<\frac{\mathrm{L}}{350}\left(3 \cdot 10^{-3} \mathrm{~m}\right) \\
& \sigma_{\mathrm{c} 0, \mathrm{~d}}=\frac{3 / 28 \cdot 0,12 \cdot 22,4 \cdot 1,05^{2}}{8,69 \cdot 10^{-7}} \cdot 2,296 \cdot 10^{-2} \\
& \sigma_{\mathrm{c} 0, \mathrm{~d}}=8386,80 \mathrm{kN} / \mathrm{m}^{2}<\mathrm{f}_{\mathrm{c} 0, \mathrm{~d}}\left(39285,71 \mathrm{kN} / \mathrm{m}^{2}\right)
\end{aligned}
$$

Com o momento estático $\mathrm{S}$ dado por:

$\mathrm{S}=2 \cdot 2,004 \cdot 8 \cdot 1,002=32,13 \mathrm{~cm}^{3}$

tem-se para as tensões cisalhantes:

$$
\tau_{\mathrm{d}}=\frac{(17 / 28) \cdot 0,12 \cdot 22,4 \cdot 1,05 \cdot 3,21 \cdot 10^{-5}}{8,69 \cdot 10^{-7} \cdot 0,16}=395,62 \mathrm{kN}<\mathrm{f}_{\mathrm{v}, \mathrm{d}}(833,33 \mathrm{kN})
$$

É bom deixar claro que a utilização do vão entre apoios de $1,05 \mathrm{~m}$ não foi aleatória, e sim devido ao vão entre os pilares e, de acordo com a condição estática pré-estabelecida $(4.1,05=4,20 \mathrm{~m})$.

Prosseguindo o cálculo, agora para os painéis laterais das fôrmas para as vigas, têm-se também deformações longitudinais e transversais, que serão contidas pelos garfos e pelos sarrafos, respectivamente. Assim como no fundo das vigas, a 
seção transversal será homogeneizada para apenas um material (chapa de madeira compensada). Será adotada chapa de madeira compensada de $18 \mathrm{~mm}$ de espessura, estruturada por três sarrafos de $2,5 \mathrm{~cm} \times 5,0 \mathrm{~cm}$. Primeiramente 0 método é detalhado para o painel lateral externo da fôrma para a viga V01, ilustrado pela FIGURA 5.20.



(a)

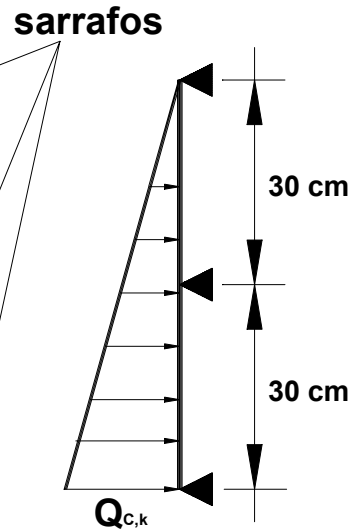

(b)

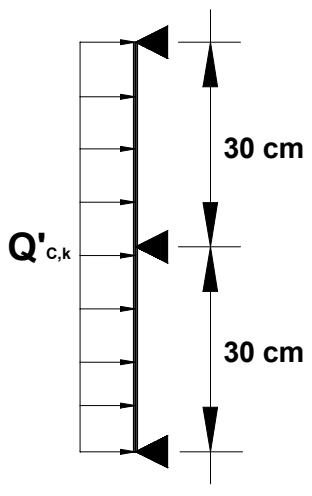

(c)

FIGURA 5.20 - (a) Seção transversal da viga V01 $(12 \mathrm{~cm}$ x $60 \mathrm{~cm})$, (b) esquema estático (painel lateral externo) com carregamento triangular e (c) simplificação com carregamento uniformemente distribuído

Inicialmente será definida a pressão lateral exercida pelo concreto nas faces, de acordo com a teoria de Mohr-Coulomb (item 4.7). Considerando para o concreto fresco um ângulo de atrito interno igual a $30^{\circ}$ e o peso específico igual a $24 \mathrm{kN} / \mathrm{m}^{2}$ (EQUAÇÃO 4.6) tem-se:

$\mathrm{Q}_{\mathrm{C}, \mathrm{k}}=(1-\operatorname{sen} \phi) \cdot \gamma_{\mathrm{C}} \cdot \mathrm{H}$

$Q_{C, k}=\left(1-\operatorname{sen} 30^{\circ}\right) \cdot 24 \cdot 0,60=7,20 \mathrm{kN} / \mathrm{m}^{2}$

Fazendo a simplificação da carga triangular (EQUAÇÃO 5.80) para uma carga uniformemente distribuída (ver FIGURA 5.20), essa não levando a erros significativos, tem-se:

$Q_{C, k}^{\prime}=7,20 \cdot 0,50=3,60 \mathrm{kN} / \mathrm{m}^{2}$ 
Para a verificação das tensões e da flecha na direção transversal, com o módulo de elasticidade nessa direção igual a $5500 \mathrm{MPa}$ e a resistência característica à compressão na flexão $45 \mathrm{MPa}$ (TABELA 5.11), por estar perpendicular à grã das lâminas externas e, utilizando o esquema estático da FIGURA 5.20, com as devidas expressões (EQUAÇÕES 5.36, 5.37 e 5.38), têm-se:

$$
\begin{aligned}
& f_{\text {máx }}=(1 / 192) \frac{3,60 \cdot 0,30^{4}}{5500000 \cdot 4,86 \cdot 10^{-7}}=0,57 \cdot 10^{-4} \mathrm{~m}<\frac{\mathrm{L}}{350}\left(8,57 \cdot 10^{-4} \mathrm{~m}\right) \\
& \sigma_{\mathrm{c} 0, \mathrm{~d}}=\frac{6 \cdot(1 / 8) \cdot 5,04 \cdot 0,30^{2}}{1 \cdot 0,018^{2}}=1050 \mathrm{kN} / \mathrm{m}^{2}<\mathrm{f}_{\mathrm{c} 0, \mathrm{~d}}\left(32142,86 \mathrm{kN} / \mathrm{m}^{2}\right) \\
& \tau_{\mathrm{d}}=\frac{3}{2} \frac{(5 / 8) \cdot 5,04 \cdot 0,30}{1 \cdot 0,018}=78,75 \mathrm{kN}<\mathrm{f}_{\mathrm{v}, \mathrm{d}}(833,33 \mathrm{kN})
\end{aligned}
$$

Aproveitando a relação da EQUAÇÃO 5.71 para a seção homogeneizada (FIGURA 5.20), têm-se o centro de gravidade, o momento de inércia (já reduzida, EQUAÇÃO 5.74) e momento estático dados por:

$$
\text { c.g. }=2,67 \mathrm{~cm}, \mathrm{I}_{\mathrm{ef}}=233,86 \mathrm{~cm}^{4} \text { e } \mathrm{S}=86,22 \mathrm{~cm}^{3}
$$

Até agora o cálculo das peças foram feitos com as expressões de flecha e tensões exatas, de acordo com a condição estática (TABELA 5.10). Entretanto, para efeito prático nas expressões de flecha e tensões (EQUAÇÕES 5.36, 5.9 e 5.12), com um número de vãos maior ou igual a três, será adotado para os coeficientes os valores apresentados em seguida, estes não induzindo a erros significativos.

$$
K_{f}=0,0065, \quad K_{M}=0,10 \text { e } K_{V}=0,60
$$

Com isso, utilizando as devidas expressões (EQUAÇÕES 5.36, 5.9 e 5.12, respectivamente) para verificar a direção longitudinal, têm-se: 
$L_{f} \leq \sqrt[3]{\frac{6,0 \cdot 10^{6} \cdot 2,34 \cdot 10^{-6}}{0,0065 \cdot 350 \cdot 3,6 \cdot 0,65}} \leq 1,38 m$

$L_{M} \leq \sqrt{\frac{39285,71 \cdot 2,34 \cdot 10^{-6}}{0,10 \cdot 3,6 \cdot 0,65 \cdot 2,67 \cdot 10^{-2}}} \leq 3,84 \mathrm{~m}$

$L_{\vee} \leq \frac{833,33 \cdot 2,34 \cdot 10^{-6} \cdot 0,24}{0,6 \cdot 3,6 \cdot 0,65 \cdot 8,62 \cdot 10^{-5}} \leq 3,86 \mathrm{~m}$

De acordo com os valores apresentados anteriormente (EQUAÇÕES 5.87, 5.88 e 5.89) percebe-se que o critério determinante para o dimensionamento é a flecha $\left(L_{f} \leq 1,38 \mathrm{~m}\right)$. É preciso lembrar que o espaçamento estabelecido no cálculo dos painéis laterais devem ser compatibilizados com o efetuado no cálculo das painéis de fundo.

Para o painel lateral interno da fôrma da viga V01 será tomado o mesmo procedimento, onde serão utilizados 2 sarrafos de $2,5 \mathrm{~cm} \times 5,0 \mathrm{~cm}$ (FIGURA 5.21).

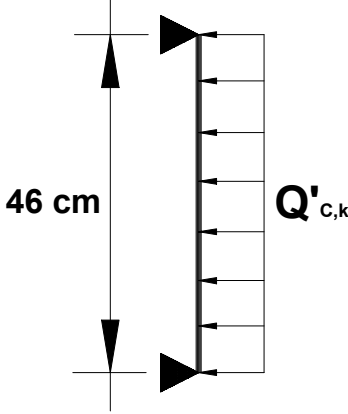

(a)

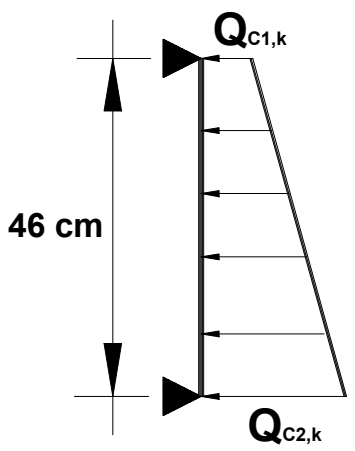

(b)



(c)

FIGURA 5.21 - (a) Simplificação com carregamento uniformemente distribuído, (b) esquema estático (painel lateral interno) com carregamento trapezoidal e (c) seção transversal da viga V01 $(12 \mathrm{~cm} \times 60 \mathrm{~cm})$

Seguindo o mesmo roteiro apresentado anteriormente, têm-se: 
$L_{f} \leq \sqrt[3]{\frac{6,0 \cdot 10^{6} \cdot 1,66 \cdot 10^{-6}}{0,0065 \cdot 350 \cdot 4,43 \cdot 0,51}} \leq 1,25 \mathrm{~m}$

$L_{M} \leq \sqrt{\frac{39285,71 \cdot 1,66 \cdot 10^{-6}}{0,10 \cdot 6,2 \cdot 0,51 \cdot 2,75 \cdot 10^{-2}}} \leq 2,74 \mathrm{~m}$

$L_{\vee} \leq \frac{833,33 \cdot 1,66 \cdot 10^{-6} \cdot 0,16}{0,6 \cdot 6,2 \cdot 0,51 \cdot 6,15 \cdot 10^{-5}} \leq 1,89 \mathrm{~m}$

Assim como no painel lateral externo percebe-se que o critério determinante para o dimensionamento é a flecha, com $\mathrm{L}_{\mathrm{f}} \leq 1,25 \mathrm{~m}$.

Os vãos máximos para os painéis de fundo de viga, lateral externo e lateral interno foram $L \leq 1,05 \mathrm{~m}, \mathrm{~L} \leq 1,38 \mathrm{~m}$ e $\mathrm{L} \leq 1,25 \mathrm{~m}$, respectivamente. No caso da utilização dos garfos de madeira como elementos de suporte do fundo e das laterais, o vão entre estes deve ser inferior a 1,05 m. No caso da utilização de outros elementos de suporte dos painéis laterais, poderia se pensar em alguma alternativa com o vão estabelecido para o painel de fundo da viga $(L \leq 1,05 \mathrm{~m})$ e o menor dos vãos determinados para os painéis laterais $(L \leq 1,25 \mathrm{~m})$.

Definido o molde e a estrutura do molde, ou seja, a distância entre os garfos, estes devem ser dimensionados para suportar a pressão lateral do concreto e as cargas verticais.

Iniciar-se-á com a verificação das extremidades em balanço do garfo (ver FIGURA 5.22), que tem a função de suportar a pressão lateral do concreto, esse funcionando como uma viga em balanço com carregamento uniformemente distribuído utilizado no cálculo dos painéis laterais da fôrma para a viga (EQUAÇÃO 5.81). Para o suporte do painel lateral externo têm-se:

$$
\begin{aligned}
& f_{\text {máx }}=(1 / 8) \frac{1,05 \cdot 3,60 \cdot 0,66^{4}}{9600000 \cdot 2,001 \cdot 10^{-6}}=4,67 \cdot 10^{-3} \mathrm{~m}>\frac{\mathrm{L}}{175}\left(3,83 \cdot 10^{-3} \mathrm{~m}\right) \\
& \sigma_{\mathrm{c} 0, \mathrm{~d}}=\frac{6 \cdot(1 / 2) \cdot 1,05 \cdot 5,04 \cdot 0,66^{2}}{0,07^{3}}=20162,06 \mathrm{kN} / \mathrm{m}^{2}<\mathrm{f}_{\mathrm{c} 0, \mathrm{~d}}\left(22857,14 \mathrm{kN} / \mathrm{m}^{2}\right)
\end{aligned}
$$




$$
\tau_{\mathrm{d}}=\frac{3}{2} \frac{(1) \cdot 1,05 \cdot 5,04 \cdot 0,66}{0,07^{2}}=1069,19 \mathrm{kN}<\mathrm{f}_{\mathrm{v}, \mathrm{d}}(3111,11 \mathrm{kN})
$$

Verificou-se que a flecha calculada excedeu a flecha limite em $20 \%$, ou seja, acabou sendo o critério determinante do dimensionamento. Entretanto, adotam-se elementos com função construtiva, que dão uma condição muito mais favorável à peça, como por exemplo, a utilização de uma guia de alinhamento para as vigas externas, maiores detalhes serão abordados em capítulo à parte.

Utilizando um carregamento, também uniformemente distribuído $\left(Q_{C, k}^{\prime}=4,43\right.$ $\mathrm{kN} / \mathrm{m}^{2}$ ), têm-se para o suporte do painel lateral interno (ver FIGURA 5.22):

$$
\begin{aligned}
& f_{\text {máx }}=(1 / 8) \frac{1,05 \cdot 4,43 \cdot 0,52^{4}}{9600000 \cdot 2,001 \cdot 10^{-6}}=2,22 \cdot 10^{-3} \mathrm{~m}<\frac{\mathrm{L}}{175}\left(3,02 \cdot 10^{-3} \mathrm{~m}\right) \\
& \sigma_{\mathrm{c} 0, \mathrm{~d}}=\frac{6 \cdot(1 / 2) \cdot 1,05 \cdot 6,20 \cdot 0,52^{2}}{0,07^{3}}=15401,21 \mathrm{kN} / \mathrm{m}^{2}<\mathrm{f}_{\mathrm{c} 0, \mathrm{~d}}\left(22857,14 \mathrm{kN} / \mathrm{m}^{2}\right) \\
& \tau_{\mathrm{d}}=\frac{3}{2} \frac{(1) \cdot 1,05 \cdot 6,20 \cdot 0,52}{0,07^{2}}=1036,28 \mathrm{kN}<\mathrm{f}_{\mathrm{v}, \mathrm{d}}(3111,11 \mathrm{kN})
\end{aligned}
$$

Verificado os suportes para a pressão lateral do concreto, passa-se para a verificação contra as ações verticais. De acordo com os espaçamentos definidos para os garfos, a escora (garfo) mais solicitada, considerando a condição estática definida para a viga V01 (4 vãos, TABELA 5.10), é:

$\mathrm{N}_{\mathrm{k}}=(8 / 7) \cdot 0,12 \cdot 16 \cdot 1,05=2,304 \mathrm{kN}$

A FIGURA 5.22, em seguida, ilustra as características geométricas da escora (garfo), esta de acordo com as dimensões da estrutura definida na FIGURA 5.7 . 




(a)

(b)

FIGURA 5.22 - (a) Vista frontal e (b) lateral do garfo usado para o escoramento das vigas

De acordo com as dimensões apresentadas anteriormente (FIGURA 5.22), a verificação admite algumas relações (item 5.6.2), mostradas em seguida.

$$
\begin{aligned}
& A_{1}=0,07 \cdot 0,07=4,9 \cdot 10^{-3} \mathrm{~m}^{2} \\
& I_{1}=I_{2}=\frac{0,07^{4}}{12}=2,001 \cdot 10^{-6} \mathrm{~m}^{4}
\end{aligned}
$$

Para a seção composta tem-se então:

$$
\begin{aligned}
& A=2 \cdot 4,9 \cdot 10^{-3}=9,8 \cdot 10^{-3} \mathrm{~m}^{2} \\
& \mathrm{I}_{x}=2 \cdot 2,001 \cdot 10^{-6}=4,002 \cdot 10^{-6} \mathrm{~m}^{4} \\
& \mathrm{I}_{y}=2 \cdot 2,001 \cdot 10^{-6}+2 \cdot 4,9 \cdot 10^{-3} \cdot 0,16^{2}=2,55 \cdot 10^{-4} \mathrm{~m}^{4}
\end{aligned}
$$


$\beta=\frac{2,001 \cdot 10^{-6} \cdot 2^{2}}{2,001 \cdot 10^{-6} \cdot 2^{2}+2,25 \cdot 2,55 \cdot 10^{-4}}=1,38 \cdot 10^{-2}$

com

$\mathrm{I}_{\mathrm{y}, \mathrm{ef}}=1,38 \cdot 10^{-2} \cdot 2,55 \cdot 10^{-4}=3,51 \cdot 10^{-6} \mathrm{~m}^{4}$

$\lambda=\frac{2,15}{\sqrt{\frac{3,51 \cdot 10^{-6}}{9,8 \cdot 10^{-3}}}}=113,6$

O momento fletor $M_{d}$ deve ser calculado pela expressão:

$M_{d}=N_{d} e_{a}\left(\frac{F_{E}}{F_{E}-N_{d}}\right)$

sendo $F_{E}$ a carga crítica, expressa por:

$F_{E}=\frac{\pi^{2} \cdot 9,6 \cdot 10^{6} \cdot 2,001 \cdot 10^{-6}}{2,15^{2}}=71,95 \mathrm{kN}$

onde $e_{a}$ é a excentricidade acidental devida às imperfeições geométricas, dada por:

$e_{a}=\frac{2,15}{300}=7,17 \cdot 10^{-3} \mathrm{~m}$

O momento fletor $M_{d}$ (EQUAÇÃO 5.108) fica, então

$M_{d}=1,4 \cdot 2,304 \cdot 7,17 \cdot 10^{-3}\left(\frac{71,95}{71,95-1,4 \cdot 2,304}\right)=2,42 \cdot 10^{-2} \mathrm{kN} \cdot \mathrm{m}$

A fim de respeitar a condição da EQUAÇÃO 5.31, e considerando as propriedades da madeira E. Grandis já apresentadas (TABELA 5.12), tem-se: 
$\frac{1,4 \cdot 2,304}{9,8 \cdot 10^{-3}}+\frac{2,42 \cdot 10^{-2} \cdot 0,07}{2 \cdot 3,51 \cdot 10^{-6}}+\frac{2,42 \cdot 10^{-2}}{2 \cdot 0,16 \cdot 4,9 \cdot 10^{-3}}\left(1-\frac{2 \cdot 2,001 \cdot 10^{-6}}{3,51 \cdot 10^{-6}}\right) \leq \mathrm{f}_{\mathrm{c} 0, \mathrm{~d}}$

$568,29 \mathrm{kN} / \mathrm{m}^{2} \leq 22857,14 \mathrm{kN} / \mathrm{m}^{2}$

Outra verificação a ser feita, seria das chapas laterais, principalmente da superior, que serve de apoio para o painel de fundo da viga. A FIGURA 5.23, em seguida, ilustra a situação.

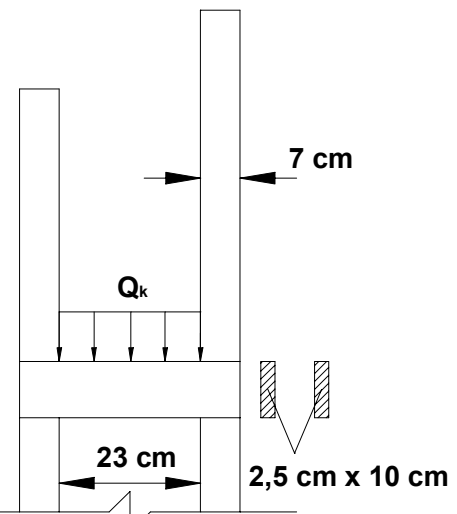

FIGURA 5.23 - Carga suportada pelas chapas laterais do garfo

Para a condição apresentada anteriormente (FIGURA 5.23) e, de acordo com o carregamento $Q_{k}$ (EQUAÇÃO 5.67), têm-se:

$f_{\text {máx }}=(5 / 384) \frac{16 \cdot 0,30^{4}}{9600000 \cdot 4,17 \cdot 10^{-6}}=0,43 \cdot 10^{-4} \mathrm{~m}<\frac{\mathrm{L}}{350}\left(9,14 \cdot 10^{-4} \mathrm{~m}\right)$

$\sigma_{\mathrm{c} 0, \mathrm{~d}}=\frac{(1 / 8) \cdot 22,4 \cdot 0,30^{2}}{4,17 \cdot 10^{-6}} \cdot 0,05=3024 \mathrm{kN} / \mathrm{m}^{2}<\mathrm{f}_{\mathrm{c} 0, \mathrm{~d}}\left(22857,14 \mathrm{kN} / \mathrm{m}^{2}\right)$

$\tau_{\mathrm{d}}=\frac{(1 / 2) \cdot 22,4 \cdot 0,30 \cdot 6,25 \cdot 10^{-5}}{4,17 \cdot 10^{-6} \cdot 0,05}=1008 \mathrm{kN} / \mathrm{m}^{2}<\mathrm{f}_{\mathrm{v}, \mathrm{d}}\left(3111,11 \mathrm{kN} / \mathrm{m}^{2}\right)$

Essa verificação dispensa a análise da segurança dos espaçadores através do esforço cisalhante da EQUAÇÃO 5.30.

Quanto a ligação das chapas laterais com os pontaletes, essa pode ser efetuada com pregos que devem resistir a um esforço cisalhante $V_{k}=2,40 \mathrm{kN}$. De 
acordo com a NBR 7190 (1997) os pregos estruturais devem ser feitos de aço com resistência característica de escoamento $f_{y, k}$ de pelo menos $600 \mathrm{MPa}$, e devem ter diâmetro mínimo de 3mm. Para o esforço cisalhante em questão tem-se:

$\phi_{\text {nec }} \geq \sqrt{\frac{4 \cdot V_{d}^{\prime}}{\pi \cdot f_{y, d}}}$

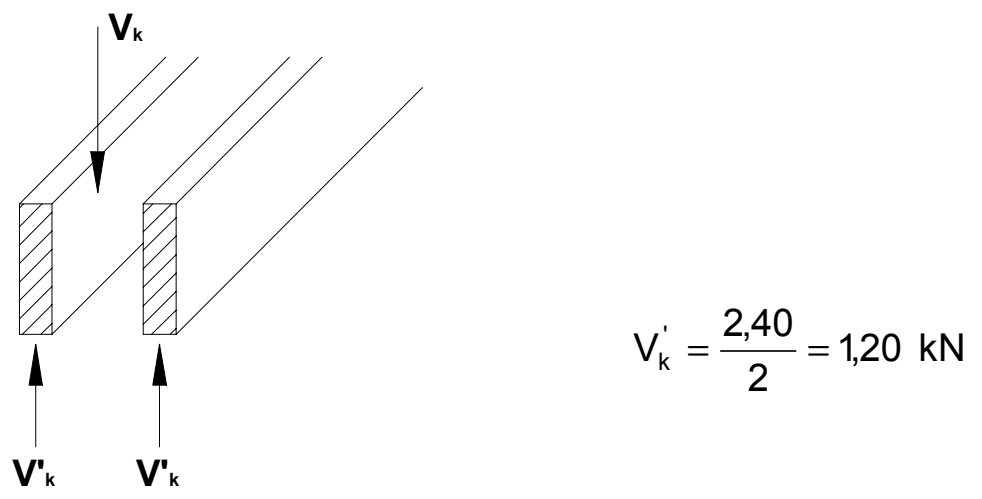

$$
\mathrm{V}_{\mathrm{k}}^{\prime}=\frac{2,40}{2}=1,20 \mathrm{kN}
$$

FIGURA 5.24 - Detalhe das

forças ativa e reativa na ligação

das chapas laterais no garfo

$\phi_{\text {nec }} \geq \sqrt{\frac{4 \cdot 1,4 \cdot 1,20}{\pi \cdot \frac{0,60}{1,15}}}=2,02 \mathrm{~mm}$

De acordo com o diâmetro encontrado $\left(\phi_{\text {nec }}=2,02 \mathrm{~mm}\right)$ necessitaria-se apenas de um prego $17 \times 27(\phi=3 \mathrm{~mm})$ por ligação. Entretanto a ligação será executada com dois pregos $17 \times 27$ por ligação, para que não haja rotação na mesma. Detalhes como espaçamento, penetração do prego, etc., devem estar de acordo com a NBR 7190 (1997).

Para que não seja necessário efetuar a verificação da estabilidade local dos trechos de comprimento $L_{1}$ dos elementos componentes (FIGURA 5.22), as limitações em seguida devem ser respeitadas:

$9 b_{1} \leq L_{1} \leq 18 b_{1}$

$0,63 \mathrm{~m} \leq 1,075 \mathrm{~m} \leq 1,26 \mathrm{~m}$ 
$a \leq 6 b_{1}$

$0,23 m \leq 0,42 m$

Durante o cálculo das fôrmas para vigas procurou-se tirar partido da condição estática que ocorre na realidade, a fim de se explorar ao máximo a capacidade das peças. Entretanto, é comum em peças de grandes comprimentos o aparecimento de juntas, quando não na chapa de madeira compensada, no próprio sarrafo, e isso pode torna falho o modelo adotado, mas que não implicará em grandes erros. Porém, uma outra maneira seria na concepção estabelecer no cálculo modelos de vigas bi-apoiada, ficando sempre a favor da segurança.

Se tal procedimento fosse adotado anteriormente, teríamos para efeito de comparação os seguintes valores (TABELA 5.14).

TABELA 5.14 - Vãos dimensionados para os painéis da fôrma da viga V01, de acordo com alguns esquemas estático

\begin{tabular}{|c|c|c|c|c|}
\hline \multirow{2}{*}{$\begin{array}{c}\text { Subsistema de } \\
\text { Fôrmas para } \\
\text { Vigas }\end{array}$} & \multirow{2}{*}{$\begin{array}{l}\text { Esquema } \\
\text { Estático }\end{array}$} & \multirow{2}{*}{$\begin{array}{c}\text { Estado } \\
\text { Limite de } \\
\text { Utilização }\end{array}$} & \multicolumn{2}{|c|}{ Estado Limite Último } \\
\hline & & & $\begin{array}{l}\text { Tensões } \\
\text { Normais }\end{array}$ & $\begin{array}{c}\text { Tensões } \\
\text { Cisalhantes }\end{array}$ \\
\hline \multirow{3}{*}{$\begin{array}{l}\text { Painel de Fundo } \\
\text { da Viga }\end{array}$} & 4 vãos ${ }^{1}$ & $\mathrm{~L} \leq 1,07 \mathrm{~m}$ & $\mathrm{~L} \leq 2,27 \mathrm{~m}$ & $\mathrm{~L} \leq 1,66 \mathrm{~m}$ \\
\hline & $\left(\right.$ Mais de 3 vãos ${ }^{2}$ ) & $(\mathrm{L} \leq 1,06 \mathrm{~m})$ & $(\mathrm{L} \leq 2,35 \mathrm{~m})$ & $(\mathrm{L} \leq 1,68 \mathrm{~m})$ \\
\hline & 1 vão ${ }^{3}$ & $\mathrm{~L} \leq 0,84 \mathrm{~m}$ & $\mathrm{~L} \leq 2,10 \mathrm{~m}$ & $\mathrm{~L} \leq 2,01 \mathrm{~m}$ \\
\hline \multirow{2}{*}{$\begin{array}{l}\text { Painel Lateral } \\
\text { Externo da Viga }\end{array}$} & Mais de 3 vãos & $\mathrm{L} \leq 1,38 \mathrm{~m}$ & $\mathrm{~L} \leq 3,84 \mathrm{~m}$ & $\mathrm{~L} \leq 3,86 \mathrm{~m}$ \\
\hline & 1 vão & $\mathrm{L} \leq 1,10 \mathrm{~m}$ & $\mathrm{~L} \leq 3,43 \mathrm{~m}$ & $\mathrm{~L} \leq 4,64 \mathrm{~m}$ \\
\hline \multirow{2}{*}{$\begin{array}{l}\text { Painel Lateral } \\
\text { Interno da Viga }\end{array}$} & Mais de 3 vãos & $\mathrm{L} \leq 1,25 \mathrm{~m}$ & $\mathrm{~L} \leq 2,74 \mathrm{~m}$ & $\mathrm{~L} \leq 1,89 \mathrm{~m}$ \\
\hline & 1 vão & $\mathrm{L} \leq 1,00 \mathrm{~m}$ & $\mathrm{~L} \leq 2,45 \mathrm{~m}$ & $L \leq 2,28 m$ \\
\hline
\end{tabular}

1. $\mathrm{K}_{\mathrm{f}}=17 / 2688, \mathrm{~K}_{\mathrm{M}}=3 / 28$ e $\mathrm{K}_{\mathrm{V}}=17 / 28$.

2. $\mathrm{K}_{\mathrm{f}}=0,0065, \mathrm{~K}_{\mathrm{M}}=0,10$ e $\mathrm{K}_{\mathrm{V}}=0,60$.

3. $K_{f}=5 / 384, K_{M}=1 / 8$ e $K_{V}=1 / 2$.

No painel de fundo da fôrma da viga os espaçamentos foram calculados com os coeficientes para a condição estática de 4 vãos e com a forma simplificada entre parênteses, ou seja, um esquema estático com mais de 3 vãos (EQUAÇÃO 5.86). Isto para mostra como a simplificação além de facilitar os cálculos, não induzem a erros expressivos. 
Através da TABELA 5.14 percebem-se as diferenças entre os espaçamentos quando na utilização de um modelo ou outro, este caindo de $L \leq 1,07 \mathrm{~m}$ (adotou-se $\mathrm{L}=1,05 \mathrm{~m}$ ) para $\mathrm{L} \leq 0,84 \mathrm{~m}$. Encontrando-se na maioria das situações a favor da segurança quando na escolha da viga bi-apoiada como modelo.

No cálculo da escora (garfo) utilizou-se o espaçamento $L=1,05 \mathrm{~m}$, com o modelo de 4 vãos, resultando numa carga $N_{k}=2,304 \mathrm{kN}$ (maior reação). No caso da utilização do modelo com 1 vão teríamos um espaçamento entre os garfos $L=$ $0,84 \mathrm{~m}$, o que resulta numa carga $\mathrm{N}_{\mathrm{k}}=1,613 \mathrm{kN}$.

\subsubsection{Subsistema de fôrmas para pilares}

As fôrmas para pilares são constituídas por painéis de chapas de madeira compensada, estruturada por sarrafos ou não, e travadas por guias (ou gravatas) de amarração (duplo sarrafo).

Inicialmente determina-se a curva de pressão lateral do concreto, de acordo com a Teoria de Mohr-Coulomb (ver item 4.7). Definida a curva de pressão lateral do concreto, de acordo o molde e a estruturação estabelecida, determinam-se os espaçamentos dos elementos (sarrafos, guias ou gravatas de amarração e tensores) que melhor atendam às solicitações. A verificação dos diferentes elementos deve ser feita segundo os critérios de ruptura na flexão e no cisalhamento, bem como quanto a flecha máxima.

Para a estrutura da FIGURA 5.7 têm-se os pilares (P01, P02, P03 e P04) com seção transversal de $20 \mathrm{~cm} \times 100 \mathrm{~cm}$ e a altura da base ao fundo da viga de $2,32 \mathrm{~m}$. Considerando para o concreto fresco um ângulo de atrito interno igual a $30^{\circ}$ e o peso específico igual a $24 \mathrm{kN} / \mathrm{m}^{2}$ (EQUAÇÃO 4.7), o valor da pressão na base fica:

$$
\begin{aligned}
& Q_{C, k}=(1-\operatorname{sen} \phi) \cdot \gamma_{C} \cdot H \\
& Q_{C, k}=\left(1-\operatorname{sen} 30^{\circ}\right) \cdot 24 \cdot 2,32=27,84 \mathrm{kN} / \mathrm{m}^{2}
\end{aligned}
$$

Para a análise numérica foi escolhido o arranjo com o painel de chapa de madeira compensada sem sarrafeamento com travamento através de guias de amarração verticais, por ser este o mais utilizado. No caso da utilização de outros 
arranjos, esses não apresentarão grande complexidade. A FIGURA 5.25, em seguida, ilustra a solução inicialmente pensada para o pilar em questão.

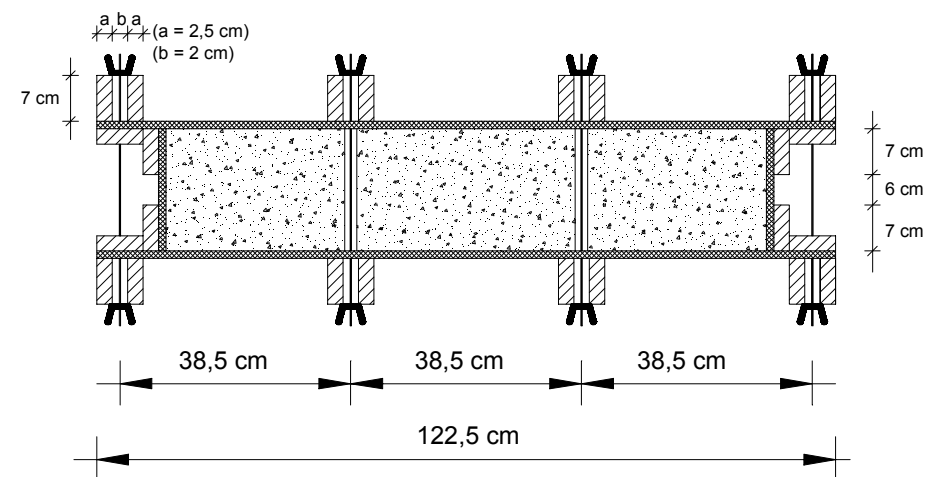

(a)

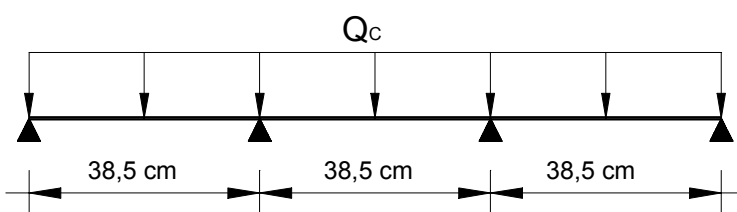

(b)

FIGURA 5.25 - (a) Seção transversal da fôrma do pilar e (b) esquema estático da pressão lateral do concreto

Definido o espaçamento horizontal dos tensores (FIGURA 5.25) torna-se necessário a verificação dos painéis de chapa de madeira compensada. Utilizando as EQUAÇÕES 5.36, 5.37 e 5.38, e de acordo com os coeficientes $\left(K_{f}, K_{M}\right.$ e $\left.K_{V}\right)$ da TABELA 5.10 têm-se:

$f_{\text {máx }}=(13 / 1920) \frac{27,84 \cdot 0,385^{4}}{5,5 \cdot 10^{6} \cdot 4,86 \cdot 10^{-7}}=1,55 \cdot 10^{-3} \mathrm{~m}>\frac{\mathrm{L}}{350}\left(1,10 \cdot 10^{-3} \mathrm{~m}\right)$

$\sigma_{\mathrm{c} 0, \mathrm{~d}}=\frac{6 \cdot(1 / 10) \cdot 38,98 \cdot 0,385^{2}}{1 \cdot 0,018^{2}}=10699,65 \mathrm{kN} / \mathrm{m}^{2}<\mathrm{f}_{\mathrm{c} 0, \mathrm{~d}}\left(32142,86 \mathrm{kN} / \mathrm{m}^{2}\right)$

$\tau_{\mathrm{d}}=\frac{3}{2} \cdot \frac{(6 / 10) \cdot 38,98 \cdot 0,385}{1 \cdot 0,018}=750,37 \mathrm{kN} / \mathrm{m}^{2}<\mathrm{f}_{\mathrm{v}, \mathrm{d}}\left(833,33 \mathrm{kN} / \mathrm{m}^{2}\right)$

Percebe-se através do cálculo da flecha $(1,55 \mathrm{~mm})$, que essa superou a flecha máxima $(1,1 \mathrm{~mm})$, o que inviabilizaria em primeira mão o esquema suposto 
na FIGURA 5.25. Entretanto, como o cálculo é efetuado com a pressão da base $\left(27,84 \mathrm{kN} / \mathrm{m}^{2}\right)$, máxima e, a ordem de grandeza da flecha, ainda assim, é pequena, torna-se aceitável o esquema estático adotado. Ainda que, as tensões normais estão em torno de $30 \%$ da resistência de cálculo.

Analisando, agora, as guias de amarração (2 sarrafos de $2,5 \mathrm{~cm} \times 7 \mathrm{~cm}$ ) para a definição do espaçamento vertical entre os tensores, têm-se como características geométricas as seguintes:

$$
\text { c.g. }=3,5 \mathrm{~cm}, \mathrm{I}=142,92 \mathrm{~cm}^{4} \text { e } \mathrm{S}=30,63 \mathrm{~cm}^{3}
$$

A madeira das guias de amarração é a E. Grandis, com suas propriedades já apresentadas e com a adoção dos coeficientes $K_{f}=0,0065, \quad K_{M}=0,10$ e $\mathrm{K}_{\mathrm{V}}=0,60$ (EQUAÇÃO 5.86, mais de 3 vãos). Utilizando as EQUAÇÕES 5.36, 5.9 e 5.12 para determinação do espaçamento têm-se:

$$
\begin{aligned}
& L_{f} \leq \sqrt[3]{\frac{9,6 \cdot 10^{6} \cdot 1,43 \cdot 10^{-6}}{0,0065 \cdot 350 \cdot 1,1 \cdot 27,84 \cdot 0,385}} \leq 0,80 \mathrm{~m} \\
& L_{M} \leq \sqrt{\frac{22857,14 \cdot 1,43 \cdot 10^{-6}}{0,10 \cdot 1,1 \cdot 38,98 \cdot 0,385 \cdot 3,5 \cdot 10^{-2}}} \leq 0,75 \mathrm{~m} \\
& L_{V} \leq \frac{3111,11 \cdot 1,43 \cdot 10^{-6} \cdot 0,05}{0,6 \cdot 1,1 \cdot 27,84 \cdot 0,385 \cdot 3,06 \cdot 10^{-5}} \leq 0,73 \mathrm{~m}
\end{aligned}
$$

Percebe-se que o critério determinante para o dimensionamento é a tensão cisalhante, com $L_{M} \leq 0,73 \mathrm{~m}$. Construtivamente e de acordo com as dimensões dos painéis têm-se para o espaçamento vertical dos tensores a seguinte disposição, ilustrada pela FIGURA 5.26. 


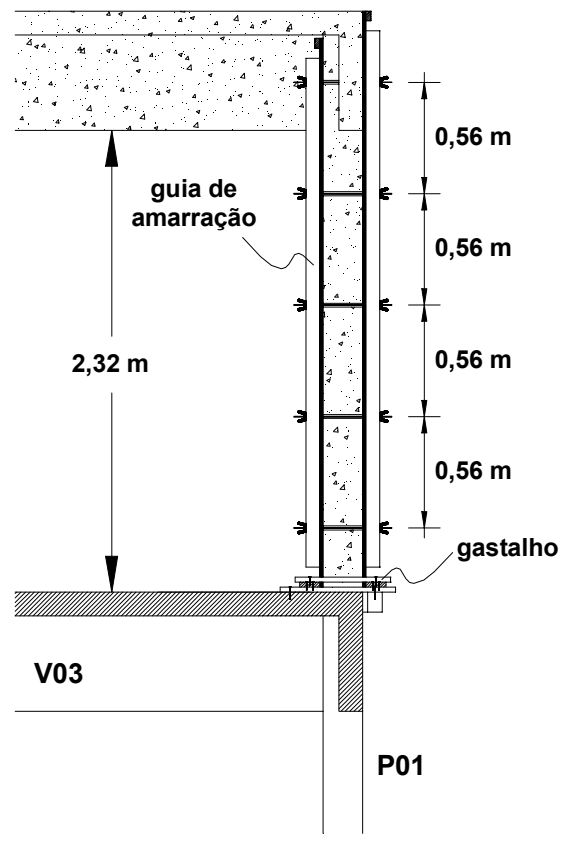

FIGURA 5.26 - Espaçamento vertical dos tensores ao longo pilar P01

Em função da distribuição triangular de pressões nos painéis verticais dos pilares, os espaçamentos entre os tensores teriam valores diferentes ao longo da altura. Entretanto, por facilidades construtivas, calcula-se o mesmo para a pressão máxima, como foi feito, adotando-se este espaçamento ao longo de todo o pilar.

Por fim, analisando os tensores, esses sendo barras de aço liso categoria CA-25 com diâmetro de 8 mm, têm-se:

$\mathrm{F}_{\mathrm{k}}=1,1 \cdot 27,84 \cdot 0,385 \cdot 0,56=6,60 \mathrm{kN}$

$\phi_{\text {nec }}=\sqrt{\frac{4 \cdot F_{d}}{\pi \cdot f_{y, d}}} \leq \phi_{\text {exist }}$

$\phi_{\text {nec }}=\sqrt{\frac{4 \cdot 1,4 \cdot 6,6}{\pi \cdot \frac{0,25}{1,15}}}=7,36 \mathrm{~mm} \leq \phi_{\text {exist }}(=8 \mathrm{~mm})$ 


\subsection{Considerações finais}

As recomendações abordadas anteriormente referem-se basicamente ao sistema de fôrmas em madeira. O que se percebe é que quando as peças que compõem o sistema de fôrmas começam a se industrializar, essas apresentam especificações de utilização fornecidas pelo fabricante. O que não impede do projetista de fôrmas comprovar através de cálculos próprios.

O intuito do capítulo, ora apresentado, mais do que expor o dimensionamento das peças que compõem o sistema de fôrmas, é servir de alicerce na elaboração de tabelas e ábacos para o dimensionamento dos subsistemas de fôrmas, de acordo com a filosofia de trabalho do projetista.

É importante que o projeto de fôrmas, em função de tudo que foi até agora discutido, não seja encarado como um mero dimensionamento de componentes. Este deve ser entendido como parte integrante de um processo que interage com as demais atividades do projeto e, principalmente, da construção. O projeto de uma edificação é cada vez mais multidisciplinar.

No Capítulo 6, a seguir, serão apresentados diferentes elementos e componentes utilizados nas construções de edifícios. Os subsistemas apresentados neste capítulo ficarão mais claros através de ilustrações mais detalhadas. Nesta oportunidade o projetista poderá se familiarizar com o sistema de fôrmas, tornandoo mais hábil nas fases de concepção e projeto.

Com o intuito de facilitar uma possível automatização do cálculo das fôrmas, no anexo estão apresentados algoritmos para os subsistemas de fôrmas para lajes, vigas e pilares. Estes algoritmos podem também serem úteis nas rotinas de cálculo dos escritórios de projeto de fôrmas. 


\section{DisPOSIÇÕES CONSTRUTIVAS}

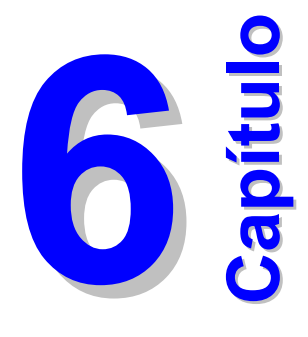

\subsection{Generalidades}

Na NBR 6118 (1978) são apontados alguns critérios relativos ao projeto e à execução de fôrmas para estruturas de concreto. Entretanto, o que se verifica é que essas indicações são colocadas de maneira muito superficial, por esta norma se referir diretamente as estruturas de concreto armado.

O que se apresenta em seguida são critérios e disposições construtivas que auxiliarão tanto na fase de concepção do projeto, como na execução das fôrmas.

Como já comentado, muitas são as tecnologias relacionadas às fôrmas, o que se pretende fazer é apresentar materiais e equipamentos, hoje comuns nacionalmente, porém, muitas vezes desconhecidos do meio técnico. Com isso, através de um profissional especializado em fôrmas, buscar a melhor solução do sistema de fôrmas a ser adotado com um estudo bem detalhado, sempre compatibilizado com a realidade da empresa (social, cultural e técnica).

Muitos caso são exemplificados de maneira muito particular, mas que esses exemplos sejam uma fonte criativa para outras soluções. 
Embora a ordem cronológica desse trabalho venha apresentar esse capítulo como um dos últimos, o mesmo é de suma importância na concepção e dimensionamento dos elementos que compõem o sistema de fôrmas.

É importante frisar a impossibilidade de se obter um sistema de fôrmas que atenda todas as obras, em todos os locais do país. Pode-se dizer que, o que são imutáveis são os fundamentos teóricos, os conceitos básicos de modo que são imprescindíveis à qualidade da obra cuja estrutura é de concreto armado.

\subsection{Fôrmas para lajes}

Em seguida serão apresentados critérios de projeto com o objetivo de criar uma estrutura básica para projetar, produzir e montar as fôrmas para lajes. Com isso pretende-se facilitar o entendimento do sistema de fôrmas no desenvolvimento do projeto, e viabilizar a execução dos mesmos.

Nas chapas que necessitarem de cortes na paginação das lajes, é importante alertar os carpinteiros na fabricação dos painéis, que nos mesmos devem ser considerada uma dimensão de $0,5 \mathrm{~cm}$ por corte, esta perdida com a serra circular.

Nas fôrmas para lajes, como já comentado anteriormente, o molde é composto por chapas de madeira compensada e a estrutura do molde pode ser definida através de transversinas e/ou longarinas, estas podendo ser de madeira, de aço ou mistas (madeira e aço). Dependendo das dimensões da laje, o molde da mesma pode ser apoiada apenas em longarinas, dispensando-se as transversinas, essa prática é adotada quando se tem a menor dimensão da laje inferior a 3,00 m e a maior não superior a $4,00 \mathrm{~m}$. O critério para utilização ou não de transversinas deve ser estudado e definido pelo projetista de fôrmas.

As transversinas e longarinas de madeira deverão ter seu comprimento limitado em 4,00 m, podendo chegar, em casos excepcionais, a valores um pouco maior. Esse fator limitante deve-se ao empenamento que as peças de madeira com grandes comprimentos apresentam e, no caso de peças mistas ou de aço, pelo seu peso durante a montagem. Em casos extremos as longarinas de madeira podem ser emendadas, devendo ser especificado no projeto a necessidade de peças superiores a 4,00 m com o detalhe da emenda, como ilustra a FIGURA 6.1. 


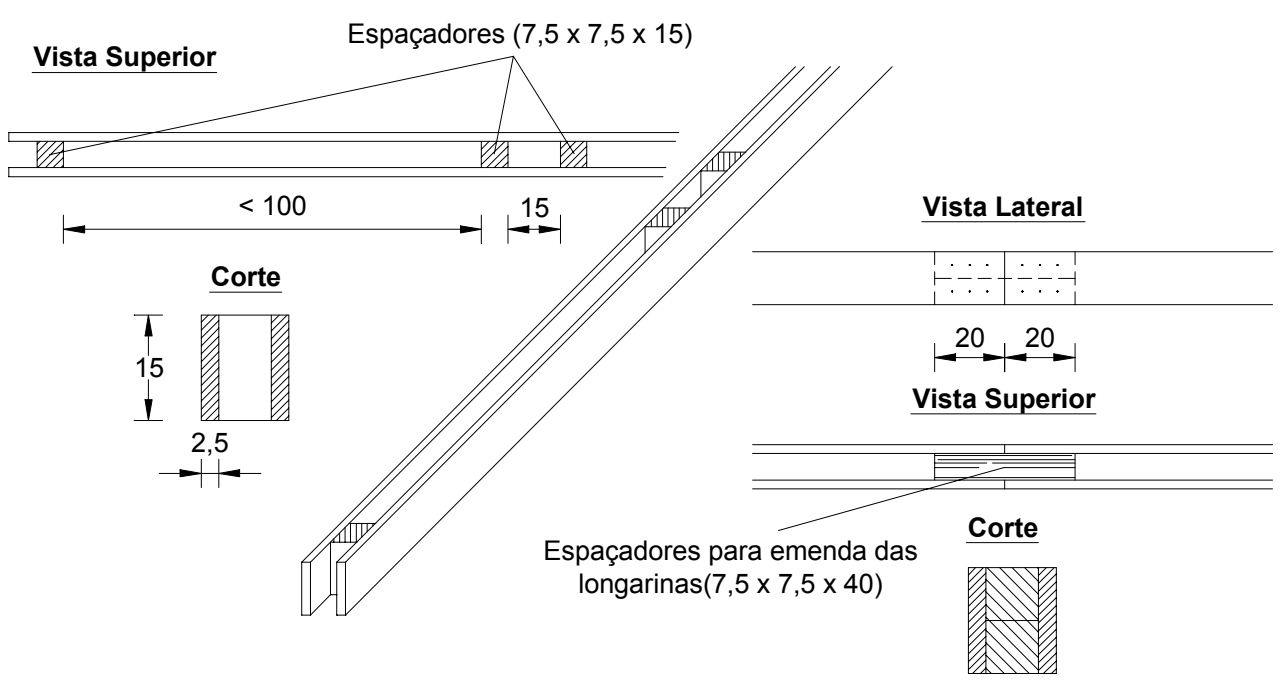

(a)

(b)

FIGURA 6.1 - (a) Longarina de madeira e (b) detalhe da emenda entre longarinas (medidas em $\mathrm{cm}$ )

Em seguida (FIGURA 6.2) são apresentadas transversinas de madeira e longarinas mistas (madeira e aço), as mais difundidas atualmente.



(a)

(b)

FIGURA 6.2 - (a) Transversina em madeira e (b) longarina mista (madeira e aço)

As transversinas ou longarinas, quando aquelas não existir, podem está apoiadas sobre guias fixadas nos garfos. A FIGURA 6.3, em seguida, ilustra a situação. 


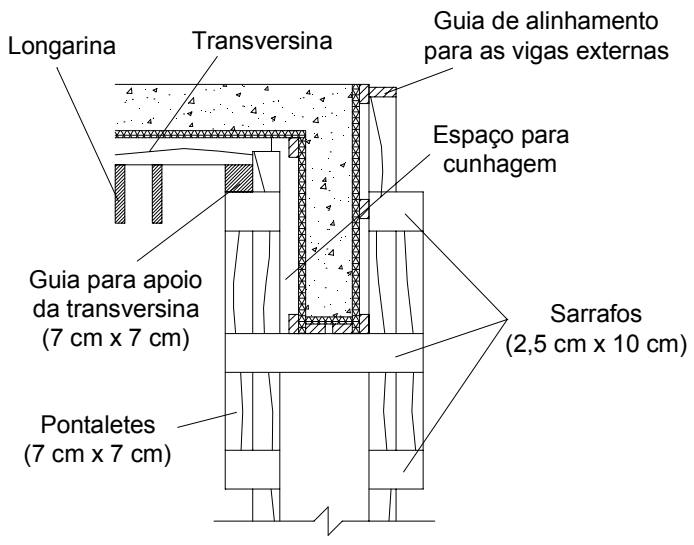

(a)

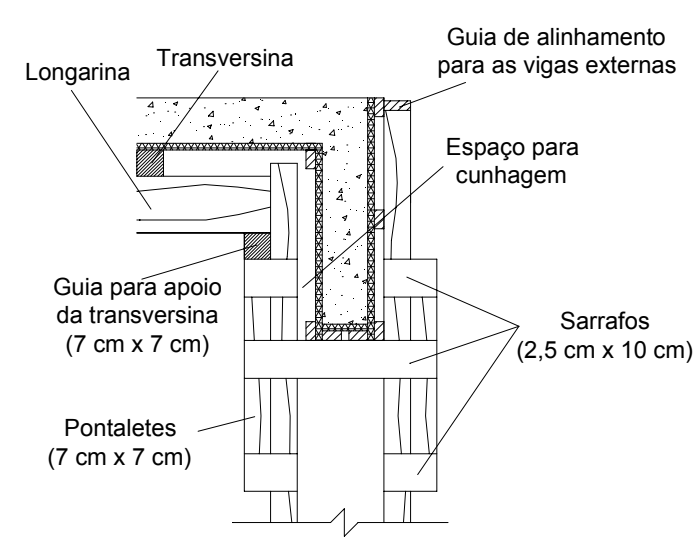

(b)

FIGURA 6.3 - Detalhe dos garfos das vigas com (a) as transversinas e (b) longarinas apoiadas em guias

O comprimento das transversinas e longarinas vai depender de como se encontra sua vinculação, ou seja, apoiada sobre guias fixadas nos garfos das vigas ou livre na extremidade, próximo do encontro dos painéis da laje e da viga (FIGURA $6.4)$.

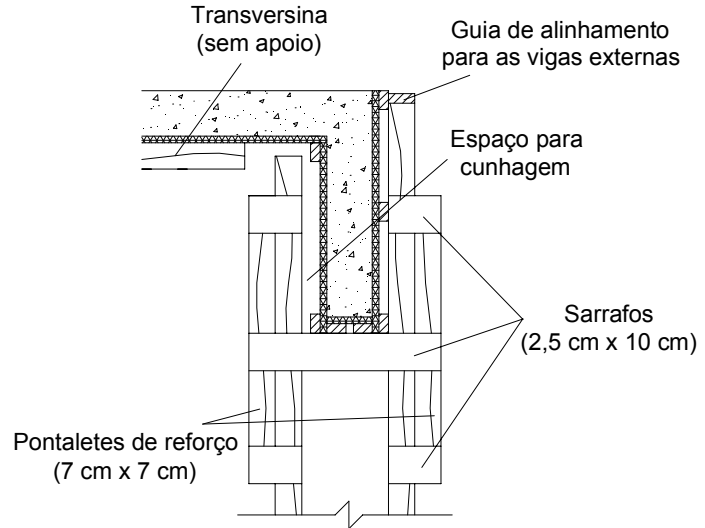

(a)

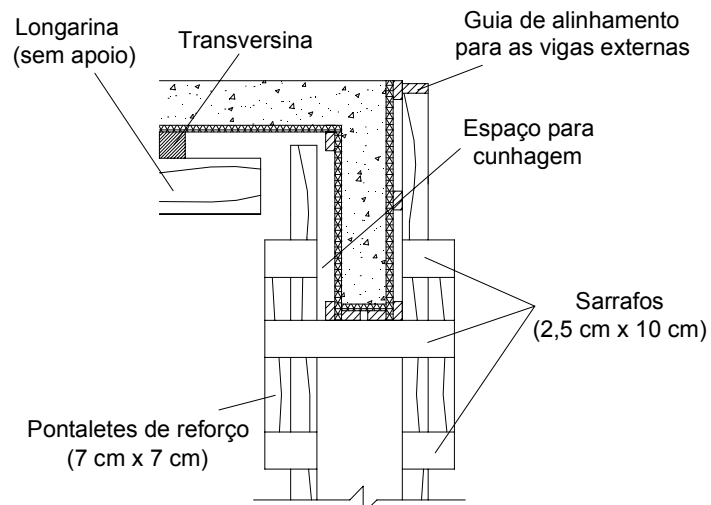

(b)

FIGURA 6.4 - Detalhe dos garfos das vigas com (a) as transversinas e (b) as longarinas sem apoio

No caso da utilização de transversinas e/ou longarinas apoiadas nas guias dos garfos das vigas (FIGURA 6.6), nesta deve ser descontado $7 \mathrm{~cm}$, por extremidade, do comprimento no projeto de estruturas. Quando se tem as extremidades livres (FIGURA 6.5) o desconto passa a ser de $20 \mathrm{~cm}$ por extremidade. 


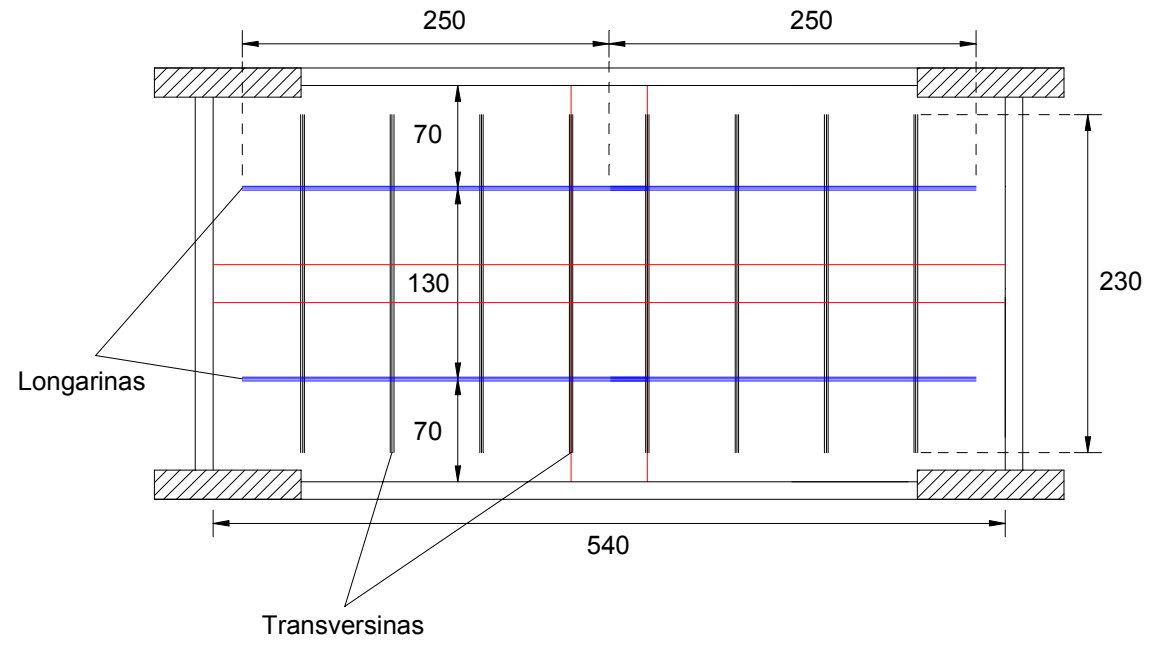

FIGURA 6.5 - Planta baixa de uma estrutura com as transversinas e longarinas não apoiadas, com desconto de $20 \mathrm{~cm}$ por extremidade (medidas em $\mathrm{cm}$ )

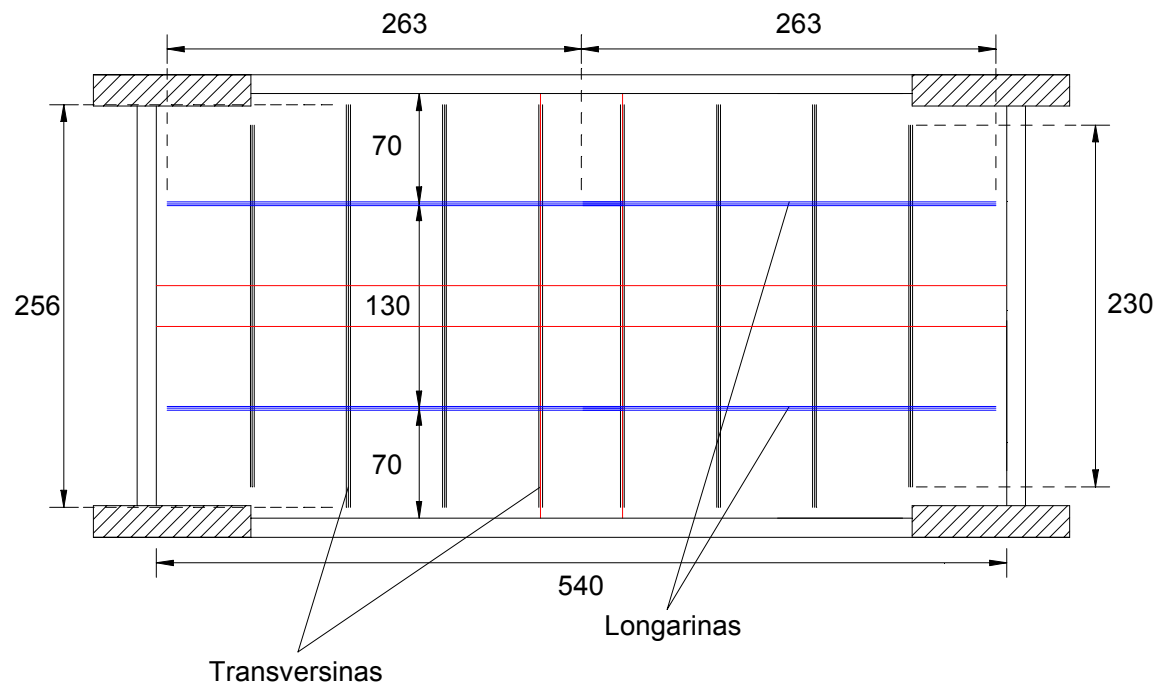

FIGURA 6.6 - Planta baixa de uma estrutura com as transversinas e longarinas apoiadas, com desconto de $7 \mathrm{~cm}$ por extremidade (medidas em $\mathrm{cm}$ )

Percebe-se na FIGURA 6.6, que as transversinas mais próximas das vigas não estão apoiadas em guias, por suas extremidades coincidirem com as faces laterais das fôrmas para os pilares, ou seja, ficando com um desconto de $20 \mathrm{~cm}$ em seus extremos.

A fixação da chapas de madeira compensada nos painéis laterais das vigas e nas transversinas ou longarinas deve ser feito através de pregos $12 \times 15$ (ver 
TABELA 5.9) distantes um do outro por no máximo $30 \mathrm{~cm}$. Na montagem nunca utilizar pregos diretamente nas bordas das chapas, e sim perpendicularmente às lâminas. A FIGURA 5.5b ilustra a ligação da fôrma da laje com a face lateral da fôrma da viga.

Com a construção acelerada dos edifícios em concreto armado, tem-se a desfôrma de um pavimento em tempo muito curto, o que faz com que a resistência do concreto esteja bem inferior a resistência normalmente especificada aos 28 dias. Com a concretagem dos pavimentos subsequentes, que se faz apoiando-se nos pavimentos imediatamente abaixo, pode ocorrer uma combinação indesejada de ações elevadas com baixas resistências do concreto. O que se faz é, através de um sistema de fôrmas, escoras e reescoras em pavimentos inferiores, aliviar estas ações elevadas com o reescoramento.

Esse reescoramento de uma estrutura é feito através de faixas de chapas previamente deixadas durante a paginação das lajes. Com isso permite-se a retirada do sistema de fôrmas para utilização nos pavimentos posteriores. Tem-se então, para uma estrutura de concreto armado, um sitema de fôrmas com escoras e tantos jogos de reescoramento quantos forem necessários, a depender da velocidade de execução da estrutura. Um benefício obtido com as faixas de reescoramento é que a partir delas pode-se iniciar a desfôrma, por apresentarem peças em menores dimensões. Para auxiliar na desfôrma dos painéis de laje, deixa-se aberturas entre as chapas da laje (faixas de reescoramento), esta sendo vedada com uma chapa metálica $\mathrm{n}^{\circ} 18(1,25 \mathrm{~mm})$, fixada com pregos de taco. $\mathrm{A}$ FIGURA 6.7, em seguida, detalha o procedimento. 


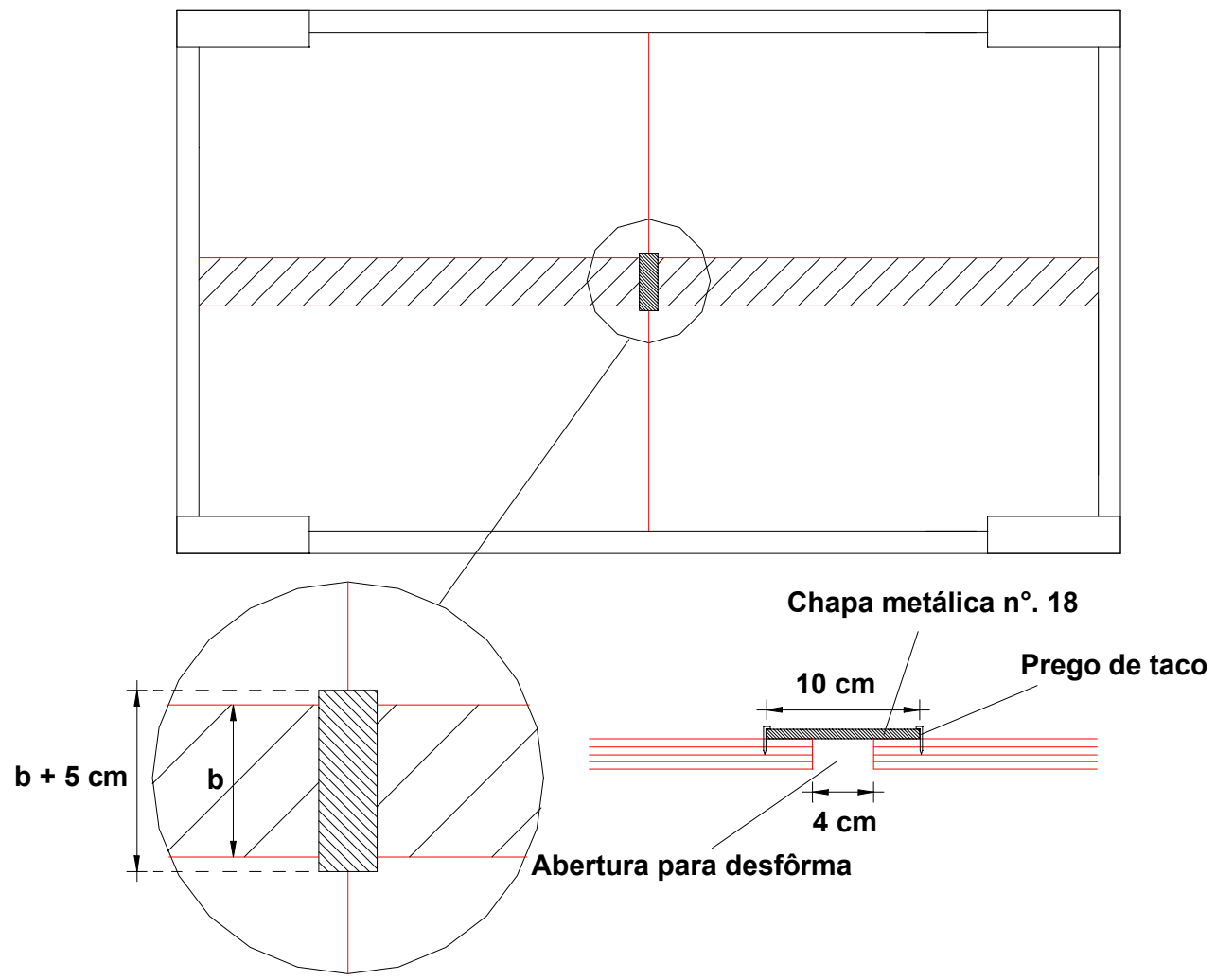

FIGURA 6.7 - Detalhe da chapa metálica na faixa de reescoramento para auxílio da desfôrma [Adaptado: ALMEIDA JÚNIOR (1996)]

O comprimento das escoras de laje depende de alguns fatores: pé-direito, utilização de transversinas e/ou longarinas, etc. De uma maneira geral tem-se para altura da escora, quando se utiliza transversinas e longarinas (FIGURA 6.8) o valor dado pela EQUAÇÃO 6.1, e quando se utiliza apenas longarinas (FIGURA 6.9) o valor dado pela EQUAÇÃO 6.2. 


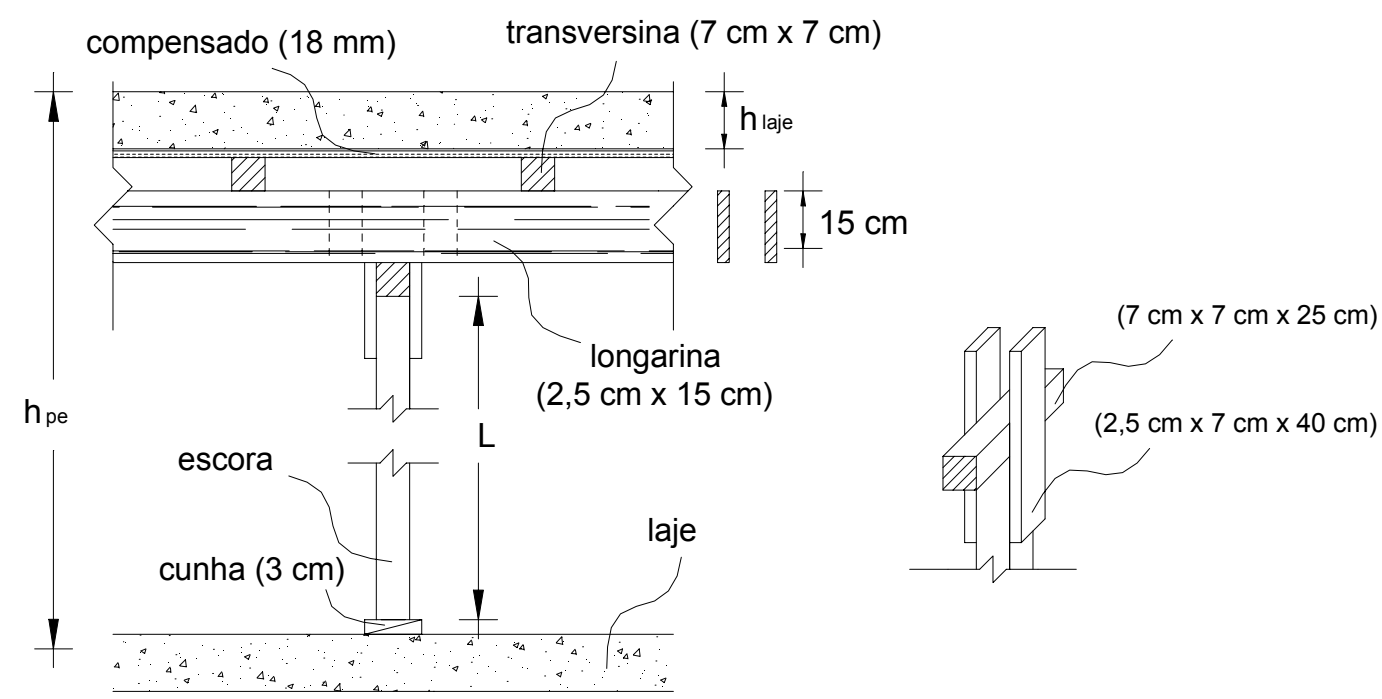

FIGURA 6.8 - Esquema de uma escora de madeira com transversina e longarina

$\mathrm{L}=\mathrm{h}_{\mathrm{pe}}-\mathrm{h}_{\text {laje }}-34 \quad(\mathrm{~cm})$

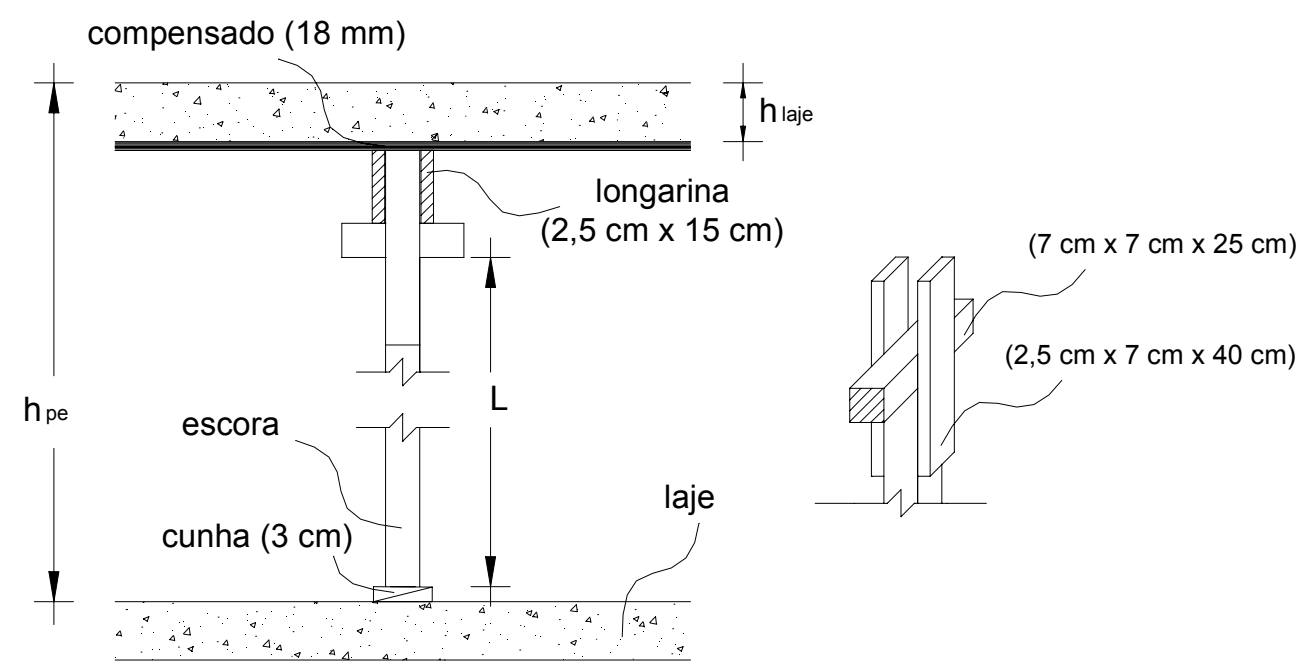

FIGURA 6.9 - Esquema de uma escora de madeira apenas com a longarina

$\mathrm{L}=\mathrm{h}_{\mathrm{pe}}-\mathrm{h}_{\text {laje }}-27 \quad(\mathrm{~cm})$

onde $h_{p e}$ é a altura do pé-esquerdo da estrutura e $h_{\text {laje }}$ é a espessura da laje. As expressões apresentadas anteriormente são para os acessórios especificados nas FIGURAS 6.8 e 6.9. Para outros casos os exemplos devem ser apenas usados de guia para a proposição de novas expressões. 
Geralmente, em algumas lajes torna-se necessário a execução de uma contra-flecha, determinada pelo projeto de estruturas. Sendo impraticável o arqueamento das chapas de madeira compensada na realização da contra-flecha, esta deve ser feita através do nivelamento das escoras. A FIGURA 6.10 ilustra o procedimento para um exemplo de laje.

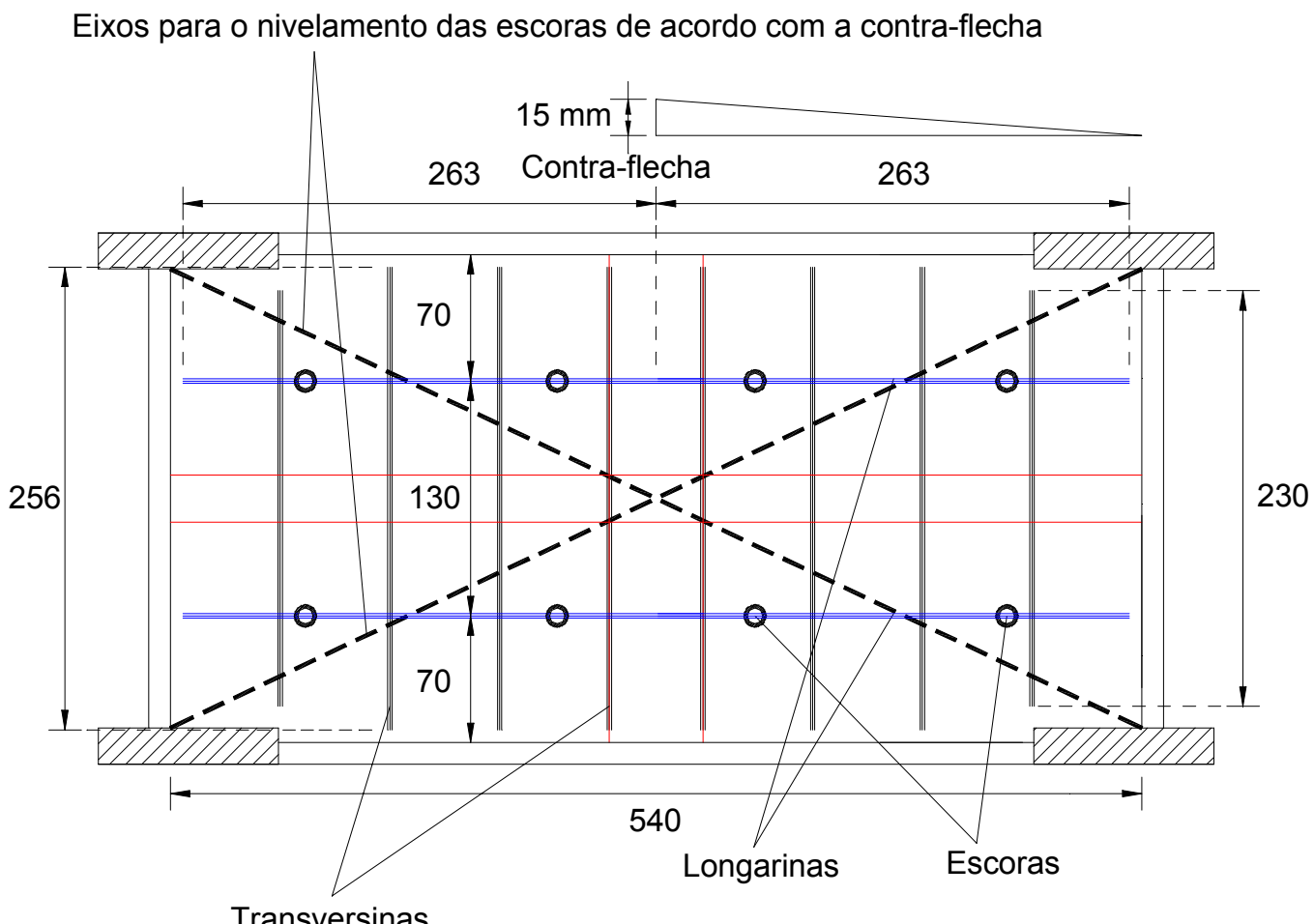

FIGURA 6.10 - Esquema de eixos para o nivelamento das escoras de acordo com a contra-flecha estabelecida no projeto de estruturas

Em seguida serão apresentados alguns acessórios atualmente disponíveis no mercado para a execução das fôrmas para lajes.

As escoras metálicas são fornecidas em aço pintado ou galvanizado. Trabalham como escoramento de vigas e lajes nas mais variadas alturas e cargas. Constituídas de dois tubos que deslizam um dentro do outro através de um sistema telescopável, são de fácil montagem e regulagem, permitindo transporte manual dentro do canteiro. Com um sistema de fácil regulagem de altura com rosca de ajuste fino, os pontaletes metálicos podem substituir com vantagens as escoras de madeira. A FIGURA 6.11, em seguida detalha as escoras metálicas. 
FIGURA 6.11 - Pontalete metálico com tubos deslizantes através de um sistema telescopável

Encontram-se, ainda, acessórios para as escoras metálicas no escoramento das fôrmas para lajes, sendo estes: o cabeçal de apoio (FIGURA 6.12) e o suporte para as escoras (FIGURA 6.13). O cabeçal de apoio é utilizado como suporte de transversinas e/ou longarinas mistas (aço e madeira), metálicas, de madeira e outros. E o suporte para as escoras serve para dar estabilidade às mesmas, permitindo que fiquem em pé sozinha. Geralmente são utilizados nas escoras iniciais do subsistema de fôrmas para lajes, quando as mesmas ainda não conseguem se manter equilibradas.

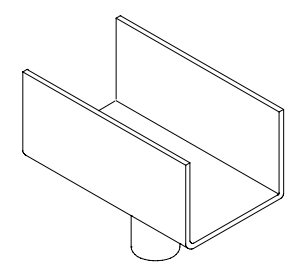

(a)

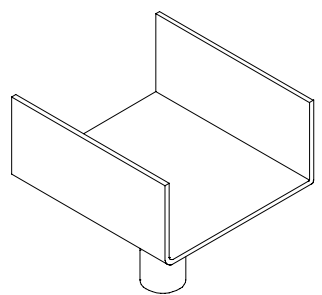

(b)

FIGURA 6.12 - Cabeçal de apoio (a) simples e (b) duplo 




FIGURA 6.13 - Suporte para pontalete metálico

O cabeçal de apoio pode ser simples (FIGURA 6.12a) ou duplo (FIGURA 6.12b). O duplo é utilizado para fazer a emenda das transversinas e/ou longarinas, a FIGURA 6.14, em seguida, detalha a emenda de uma transversina mista.

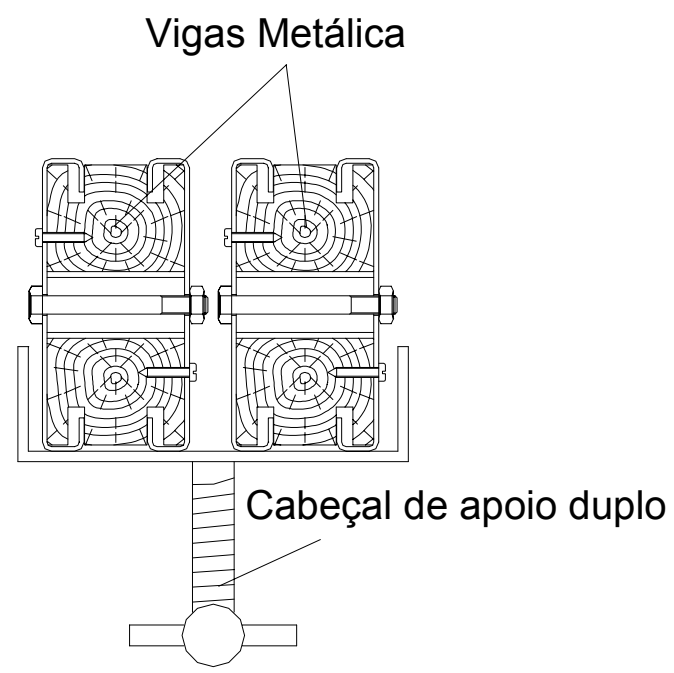

FIGURA 6.14 - Emenda de transversinas mistas através do cabeçal duplo

As escoras em torres metálicas são fabricadas em elementos de aço com grande capacidade de carga, montagem rápida e dispensa uso de ferrementas sofisticadas para montagem, com grande utilização quando se tem um alto pédireito. As torres metálicas podem ser com base quadrada e triangular, nas mesmas é possível receber os cabeçais de apoio, bem como as sapatas fixas, para melhor apoio no solo.

O escoramento da laje deve ser travado a meia altura sempre que a altura da mesma superar $3,00 \mathrm{~m}$, ou quando por análise do projetista de fôrmas ficar evidenciado a necessidade de contraventar o sistema de fôrmas. Este travamento 
(ou contraventamento) deve ser efetuado através de braçadeiras fixadas que interliguem as escoras com as peças responsáveis pelo travamento (tubos de aço, peças de madeira, cantoneiras, etc.).

\subsection{Fôrmas para vigas}

Agora serão apresentados os critérios de projeto com o objetivo de criar uma estrutura básica para projetar, produzir e montar as fôrmas para vigas.

Inicialmente, torna-se importante definir o comprimento das chapas laterais e de fundo das fôrmas para vigas. O painel de fundo é igual a largura da viga, o painel lateral externo é dado pela EQUAÇÃO 6.3 e o painel lateral interno, dado pela EQUAÇÃO 6.4 (vigas externas). A FIGURA 6.15 ilustra a seção transversal da fôrma de uma viga externas (ou de perímetro).



FIGURA 6.15 - Seção transversal de uma viga de perímetro com as dimensões dos painéis

$$
\begin{aligned}
& \mathrm{h}_{\text {painel }}=\mathrm{h}_{\mathrm{v}}+4-\mathrm{h}_{\text {laje }}-2 \quad(\mathrm{~cm}) \\
& \mathrm{h}_{\text {painel }}=\mathrm{h}_{\mathrm{v}}+4(\mathrm{~cm})
\end{aligned}
$$

onde $h_{\text {painel }}$ é a altura do painel, $h_{v}$ é a altura da viga da estrutura e $h_{\text {laje }}$ é a espessura da laje. É bom frisar que as expressões ora apresentadas são para as fôrmas especificadas na FIGURA 6.16, ou seja, com chapas de madeira 
compensada de $18 \mathrm{~mm}$ e sarrafos com espessura em torno de $2,5 \mathrm{~cm}$. Para outros casos o exemplo deve ser apenas usado de guia para a proposição de novas expressões.

Provavelmente as dimensões comerciais das chapas de madeira compensada não atenderão aos comprimentos das faces laterais e de fundo das fôrmas das vigas, tornando-se necessário a execução de emendas dos painéis, esta deve ser indicada e detalhada no projeto. Em seguida, a FIGURA 6.16 ilustra a emenda entre dois painéis de fôrmas de viga através de chapuz.
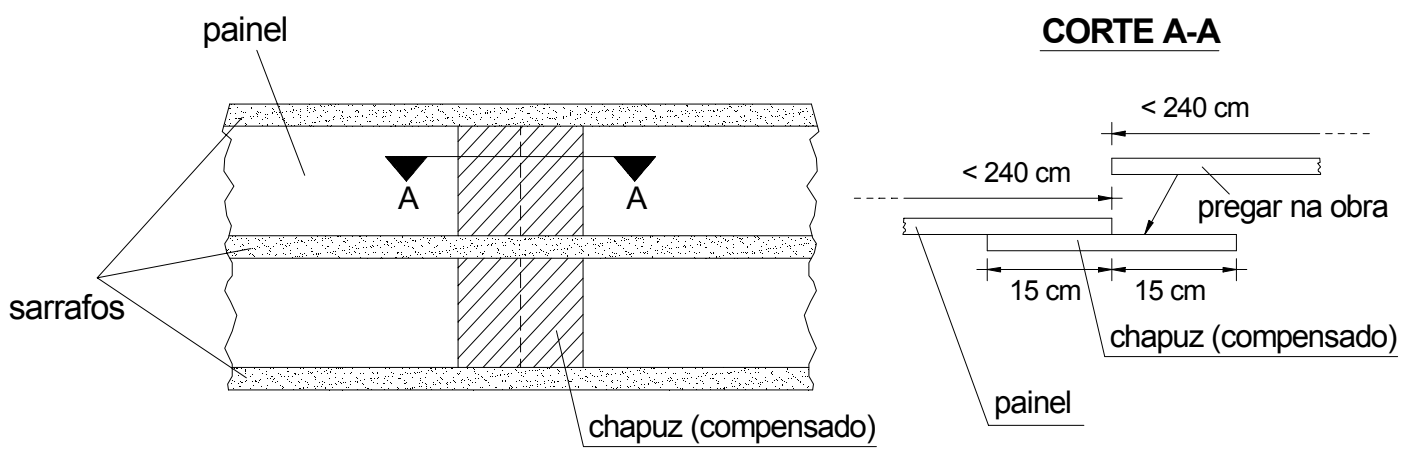

FIGURA 6.16 - Emenda entre dois painéis de viga através de chapuz

Em seguida são mostrados garfos para as viga diretas, invertidas e semiinvertidas, estas tanto internas como as externas (ou de perímetro), ver FIGURAS $6.17,6.18$ e 6.19 . 


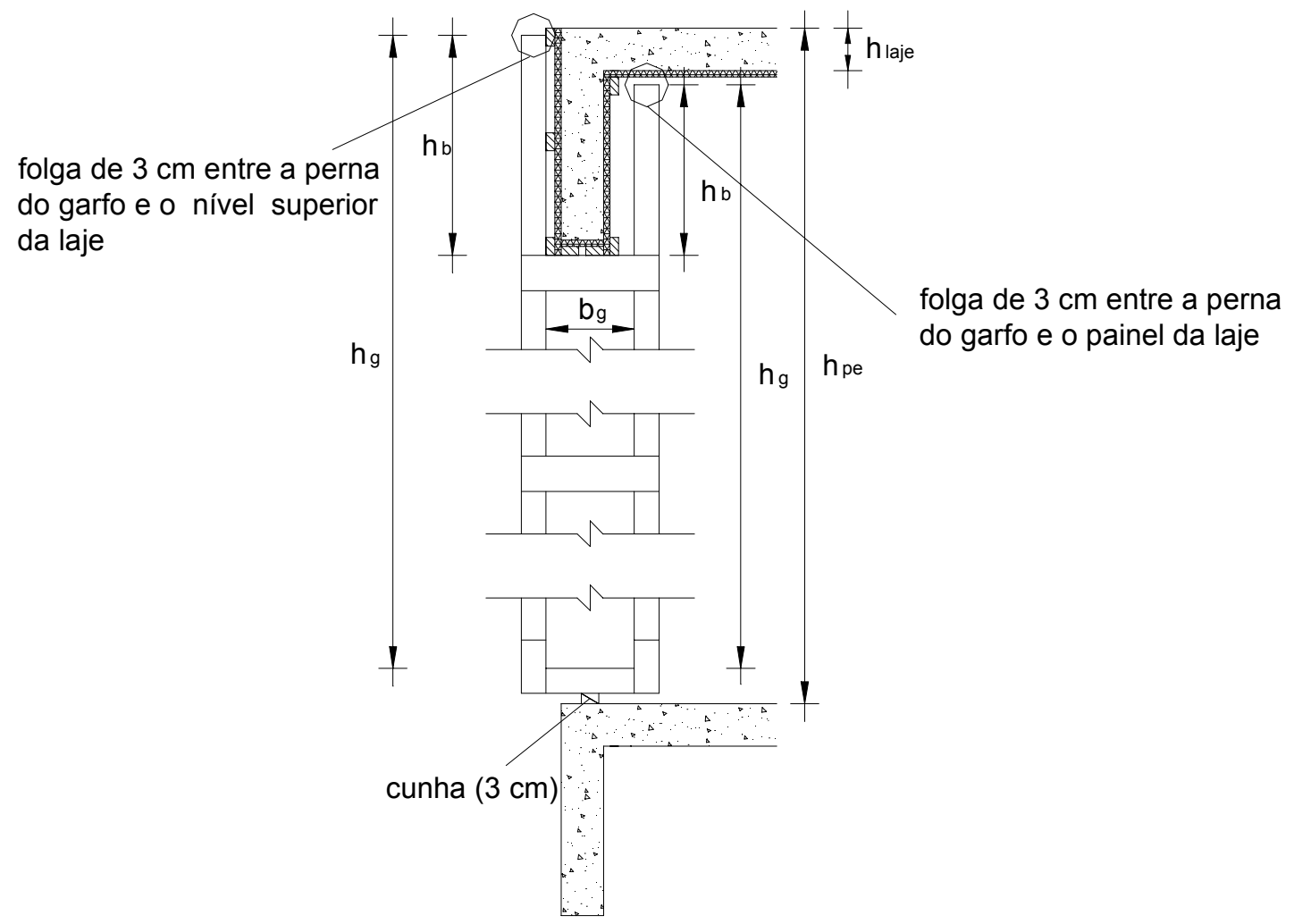

FIGURA 6.17 - Viga direta de perímetro

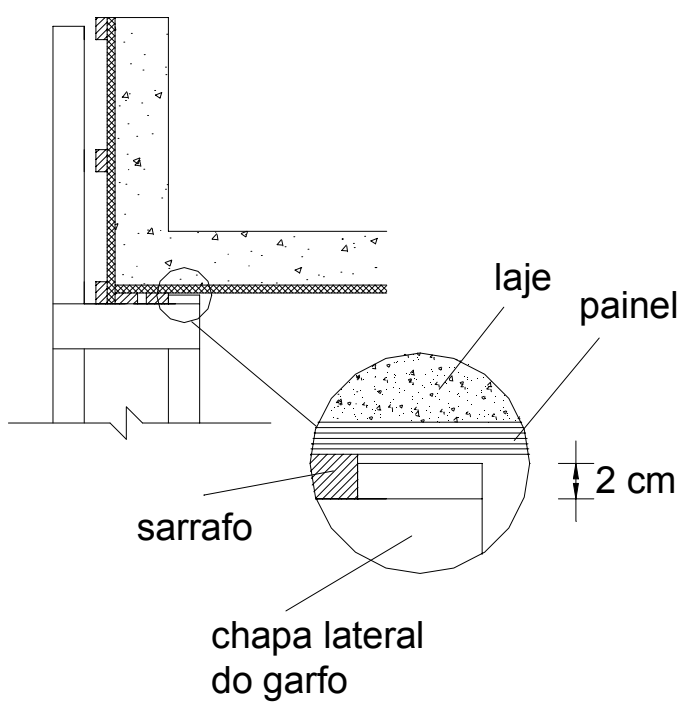

FIGURA 6.18 - Viga invertida de perímetro 


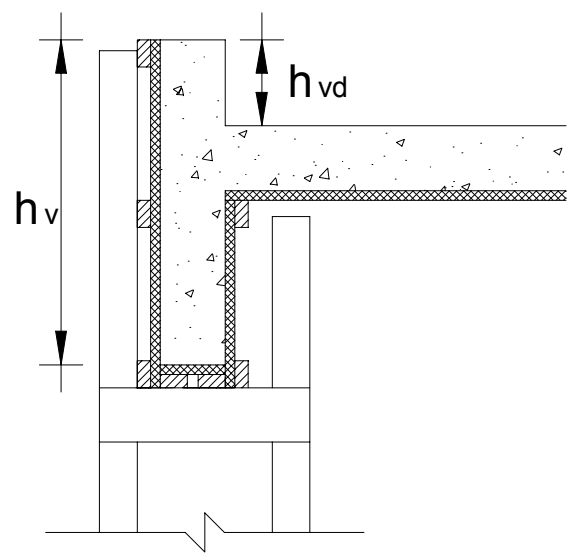

FIGURA 6.19 - Viga semi-invertida de perímetro

$\mathrm{Na}$ TABELA 6.1 estão definidos os comprimentos dos elementos que formam o garfo, de acordo com as FIGURAS 6.17, 6.18 e 6.19, mostradas anteriormente.

TABELA 6.1 - Comprimentos dos elementos que formam o garfo, de acordo com a viga a ser escorada

\begin{tabular}{|c|c|c|c|c|}
\hline \multicolumn{2}{|c|}{ Vigas } & \multirow{2}{*}{$\begin{array}{c}\text { Altura da perna do } \\
\text { garfo }\left(\mathbf{h}_{\mathbf{g}}\right) \\
\mathrm{h}_{\mathrm{pe}}-\mathrm{h}_{\text {laje }}-15\end{array}$} & \multirow{2}{*}{$\begin{array}{c}\text { Espaço } \\
\text { entre as } \\
\text { pernas } \\
\left(b_{g}\right) \\
b_{v}+11\end{array}$} & \multirow{2}{*}{$\begin{array}{c}\text { Altura do balanço } \\
\text { da perna do garfo } \\
\left(h_{b}\right) \\
h_{v}-h_{\text {laje }}-1\end{array}$} \\
\hline & Interna & & & \\
\hline $\begin{array}{l}\text { Vigas } \\
\text { Diretas }\end{array}$ & Externa & $\begin{array}{c}\mathrm{h}_{\mathrm{pe}}-13^{*} \\
\mathrm{~h}_{\mathrm{pe}}-\mathrm{h}_{\text {laje }}-15^{* *}\end{array}$ & $b_{v}+11$ & $\begin{array}{c}\mathrm{h}_{\mathrm{v}}+1^{*} \\
\mathrm{~h}_{\mathrm{v}}-\mathrm{h}_{\text {laje }}-1^{* *}\end{array}$ \\
\hline \multirow[b]{2}{*}{$\begin{array}{c}\text { Vigas } \\
\text { Invertidas }\end{array}$} & Interna & $h_{p e}-h_{v}-12$ & $b_{v}+1$ & 2 \\
\hline & Externa & $\begin{array}{c}h_{p e}-13 \\
h_{p e}-h_{v}-12\end{array}$ & $b_{v}+7$ & $\begin{array}{c}\mathrm{h}_{\mathrm{v}}+1 \\
2\end{array}$ \\
\hline \multirow{2}{*}{$\begin{array}{c}\text { Vigas Semi- } \\
\text { invertidas }\end{array}$} & Interna & $h_{p e}-h_{v e}-h_{\text {laje }}-15$ & $b_{v}+11$ & $\mathrm{~h}_{\mathrm{v}}-\mathrm{h}_{\mathrm{ve}}-\mathrm{h}_{\text {laje }}-1$ \\
\hline & Externa & $\begin{array}{c}\mathrm{h}_{\mathrm{pe}}-13^{*} \\
\mathrm{~h}_{\mathrm{pe}}-\mathrm{h}_{\mathrm{vd}}-\mathrm{h}_{\text {laje }}-15^{* *}\end{array}$ & $b_{v}+11$ & $\begin{array}{c}\mathrm{h}_{\mathrm{v}}+1^{*} \\
\mathrm{~h}_{\mathrm{v}}-\mathrm{h}_{\mathrm{vd}}-\mathrm{h}_{\text {laje }}-1^{* *}\end{array}$ \\
\hline
\end{tabular}

${ }^{*}$ Referente ao lado esquerdo da viga.

** Referente ao lado direito da viga. 
Adota-se reforços nas extremidades dos garfos com dupla finalidade. Uma delas é servir de apoio para uma guia (pontalete) que receberá as transversinas e/ou longarinas. A outra necessidade de reforçar aquela região, é a deficiência de seção resistente percebida no cálculo estático. As FIGURAS 6.3 e 6.4, ora apresentadas, detalha o reforço nos garfos.

Com a diferença entre os pés-direito do pavimento tipo para os pavimentos em comum (garagem, lazer, etc.), esses freqüentemente maiores que aqueles, o que se faz é conceber o sistema de fôrmas para o pavimento tipo, por este apresentar um maior número de repetições, com isso faz-se as devidas adapatações para os outros pavimentos. Para ilustrar a situação (FIGURA 6.20), tem-se por exemplo uma escora tipo garfo, onde no térreo ele apresenta um pédireito maior que no pavimento tipo. Para facilitar o trabalho dos carpinteiros no canteiro, através de sarrafos, delimita-se a posição do corte adaptando-o para os pavimentos subsequentes.

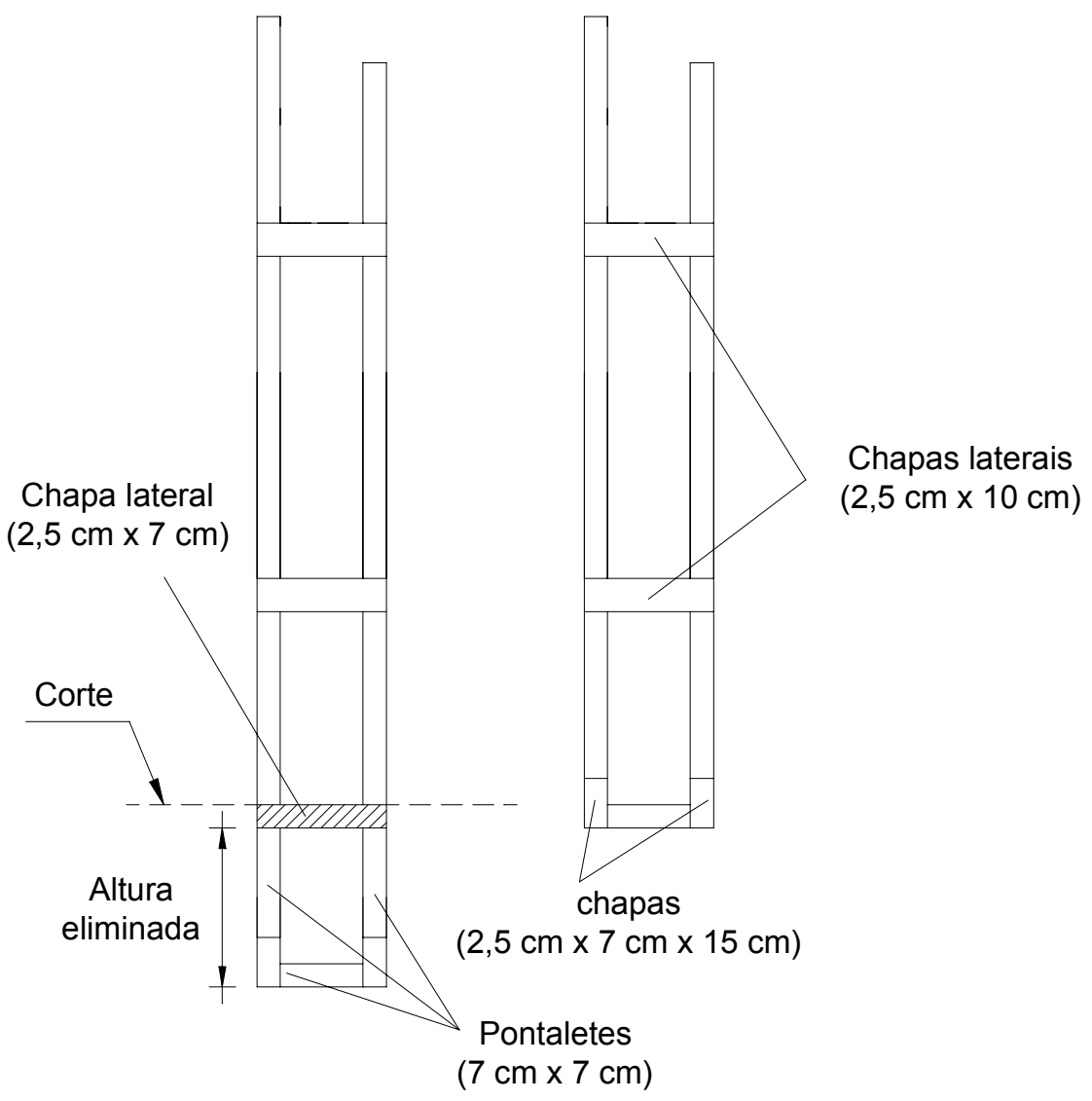

FIGURA 6.20 - Corte do garfo para utilização nos pavimentos tipo 
Em seguida serão apresentados alguns acessórios atualmente disponíveis no mercado para a execução das fôrmas para vigas.



FIGURA 6.21 - Tensores para vigas de grande altura

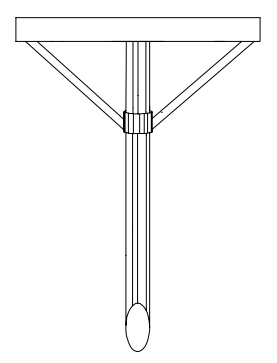

FIGURA 6.22 - Cruzeta, para suporte de vigas

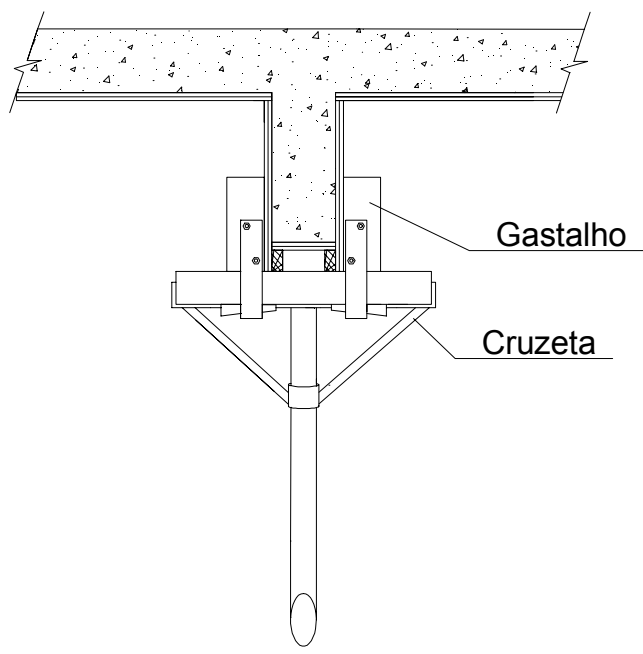

FIGURA 6.23 - Gastalho, para travamento das faces laterais das fôrmas 
Algumas vezes, de acordo com o cálculo estático, as vigas por apresentarem alturas maiores podem necessitar de reforços através de gravatas. $A$ FIGURA 6.25 detalha a situação.

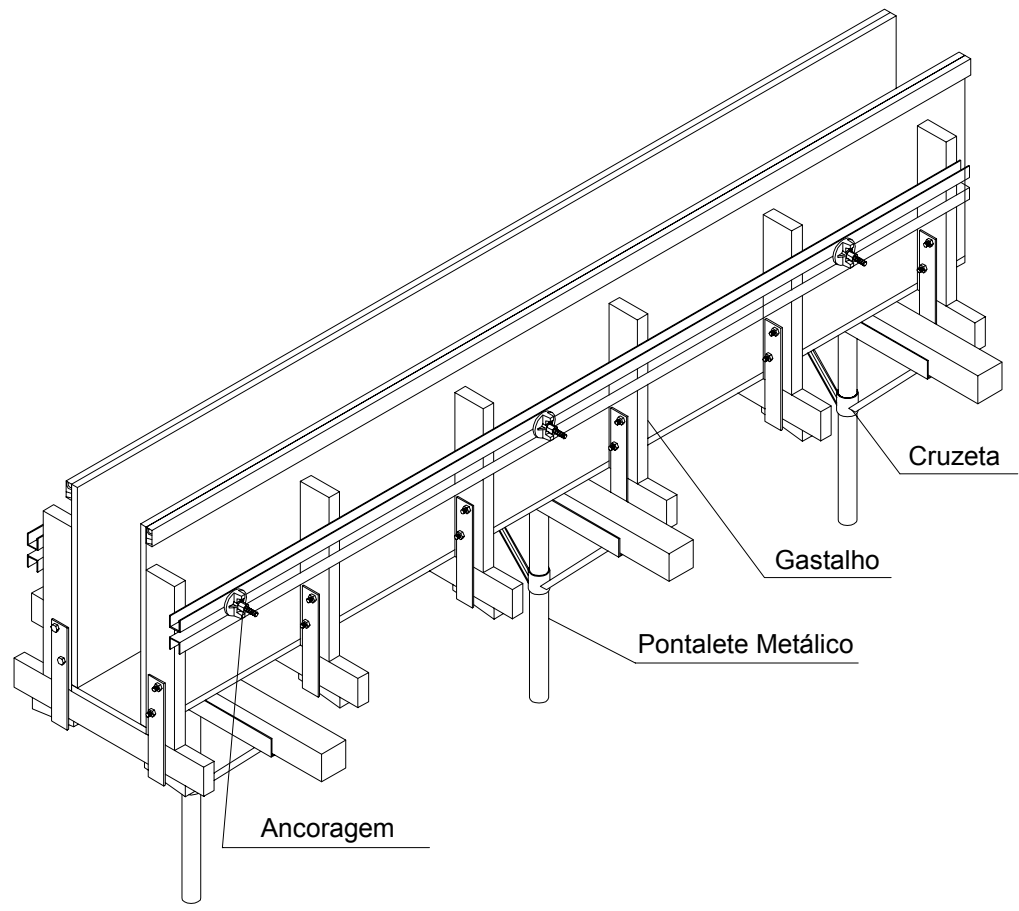

FIGURA 6.24 - Fôrma de viga com reforço através de gravatas a meia altura

Em seguida está apresentado um escoramento de vigas e laje utilizando-se torres com longarinas mistas (vigas metálicas) e cabeçais de apoio reguláveis (FIGURA 6.25). 


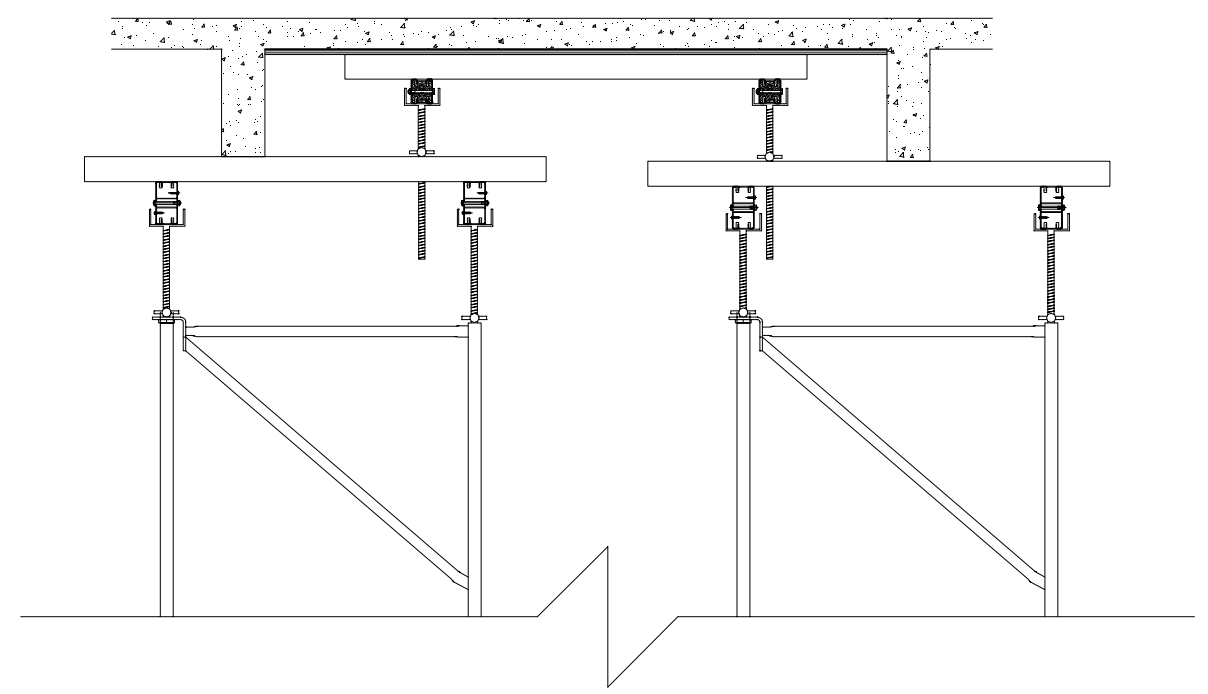

FIGURA 6.25 - Escoramento de vigas e laje utilizando-se torres e vigas metálicas

Assim como foi comentado nas fôrmas para lajes o escoramento deve ser travado quando necessitar, bem como deve-se contar com mãos francesa para alinhamento das fôrmas para as vigas externas.

\subsection{Fôrmas para pilares}

As fôrmas para pilares apresentam várias soluções, com a utilização de chapas de madeira compensada (plastificada ou resinada), têm-se 4 tipos de arranjos: chapas de madeira compensada sarrafeada horizontalmente com travamento através de guias de amarração verticais (duplo sarrafo); chapas de madeira compensada sarrafeada verticalmente com travamento através de gravatas de amarração horizontais; chapas de madeira compensada sem sarrafeamento, travados através de guias de amarração verticais e chapas de madeira compensada sem sarrafeamento, travados através de gravatas de amarração horizontais. A seguir estão apresentados os detalhes de cada arranjo, através das FIGURAS 6.26, 6.27, 6.28 e 6.29. 

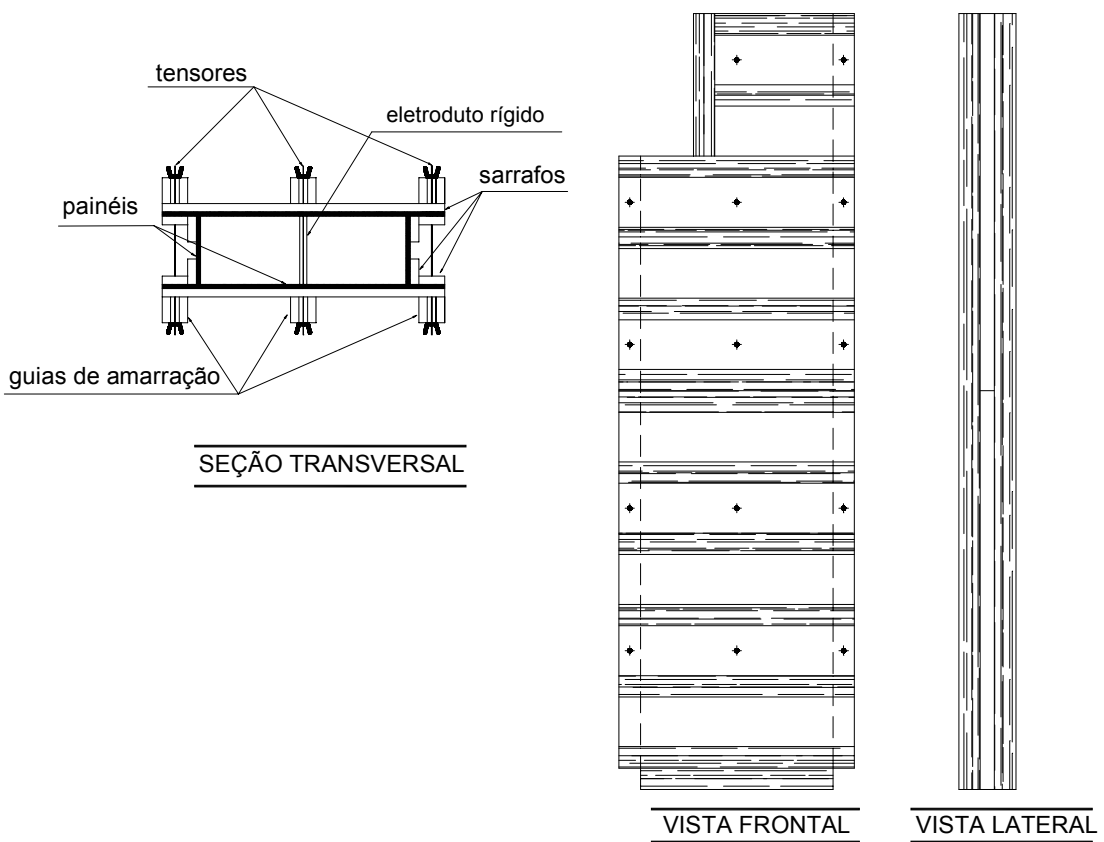

FIGURA 6.26 - Seção transversal, vista frontal e lateral da fôrma de um pilar com sarrafeamento horizontal

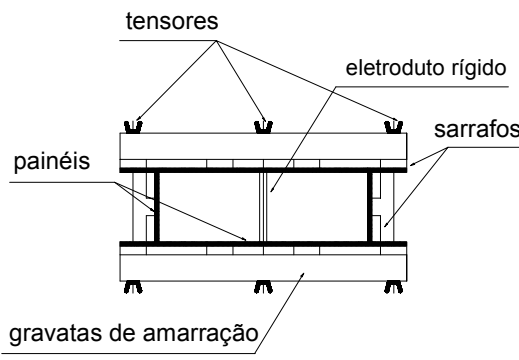

$\overline{\text { SEÇÃO TRANSVERSAL }}$

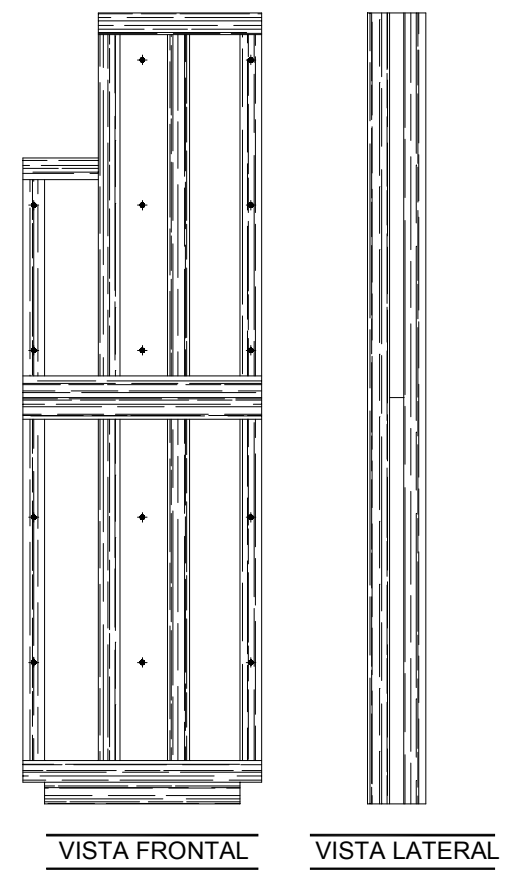

FIGURA 6.27 - Seção transversal, vista frontal e lateral da fôrma de um pilar com sarrafeamento vertical 

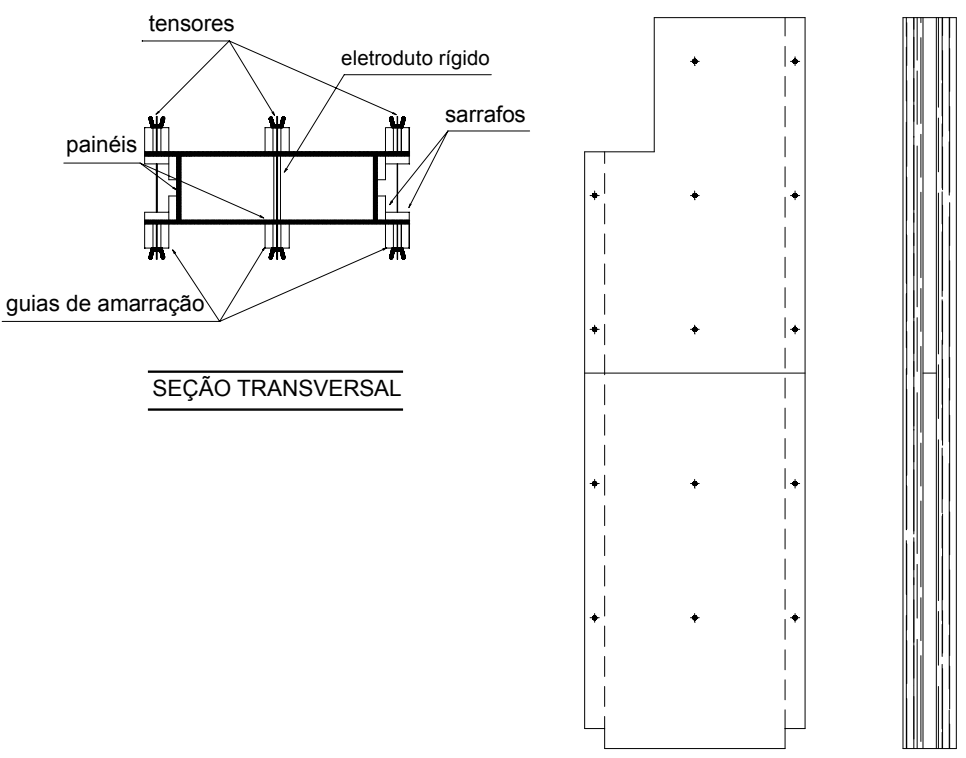

$\overline{\text { VISTA FRONTAL }} \quad \overline{\text { VISTA LATERAL }}$

FIGURA 6.28 - Seção transversal, vista frontal e lateral da fôrma de um pilar sem sarrafeamento, travado através de guias de amarração
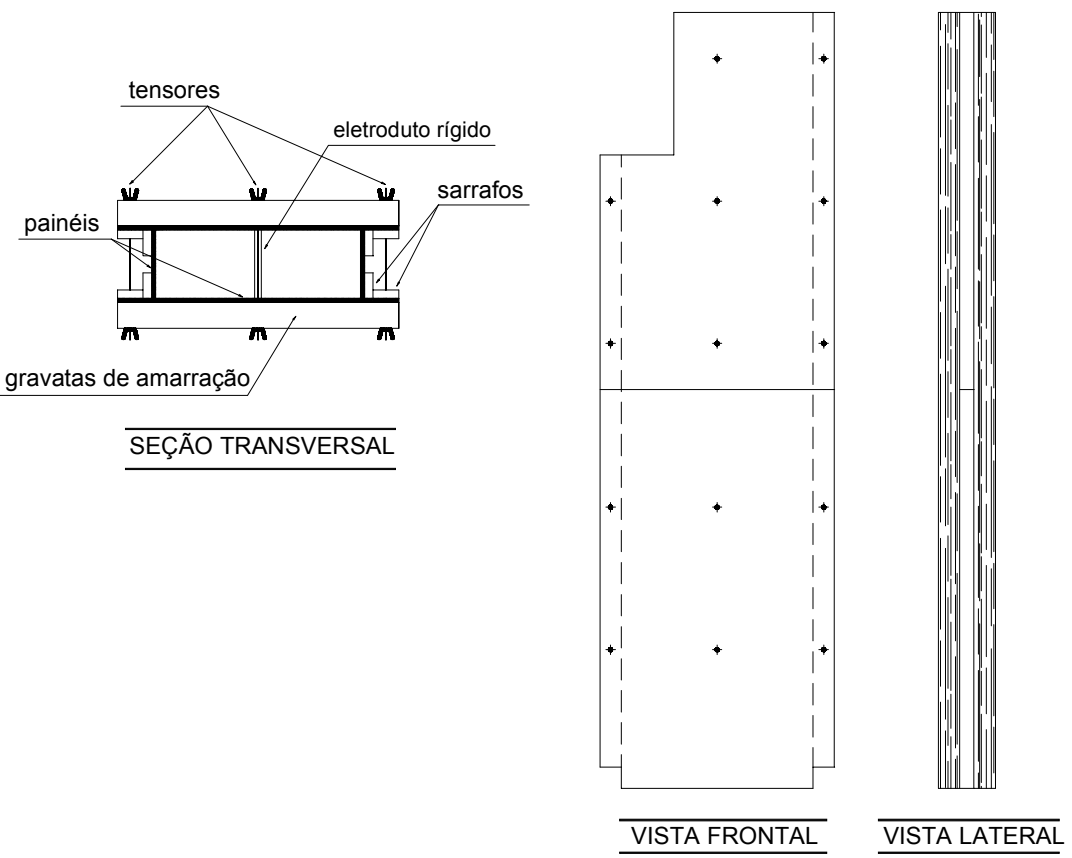

FIGURA 6.29 - Seção transversal, vista frontal e lateral da fôrma de um pilar sem sarrafeamento, travado através de gravatas de amarração

$\mathrm{Na}$ ordem de desfôrma, se faz geralmente, a retirada dos painéis dos pilares primeiramente, em seguida os painéis laterais das vigas, ficando por último os painéis de fundo das vigas e os painéis das lajes. Portanto, o que se faz é entrar 
com os painéis de laje sobre os painéis de viga e pilares. Fazendo o mesmo no encontro dos painéis de viga e pilares, semelhante ao que estar ilustrado na FIGURA 5.5 .

Outra prática é a adoção de elementos de pressão (moscas), que evitam o contato das extremidades dos painéis com o concreto fresco, no item 6.6 será dada mais ênfase a esses elementos.

A locação dos pilares é feita de acordo com os gastalhos previamente deixados na concretagem da laje precedente. A fixação dos gastalhos deve ser iniciada em condições ideais, sem interferência, com a área totalmente desimpedida, distante $10 \mathrm{~cm}$ da face do pilar. Após a concretagem da laje, deve ser a primeira atividade, tendo um prazo de $6 \mathrm{~h}$ a $12 \mathrm{~h}$.

Os gastalhos são elementos de madeira utilizados na locação e no auxílio para prumagem e contraventamento lateral das fôrmas para pilares. Tem-se pois, o gastalho para a locação das fôrmas dos pilares, detalhado pela FIGURA 6.30, e o gastalho "maluco", que auxilia no contraventamento e prumagem dos painéis, conforme detalhe da FIGURA 6.31.
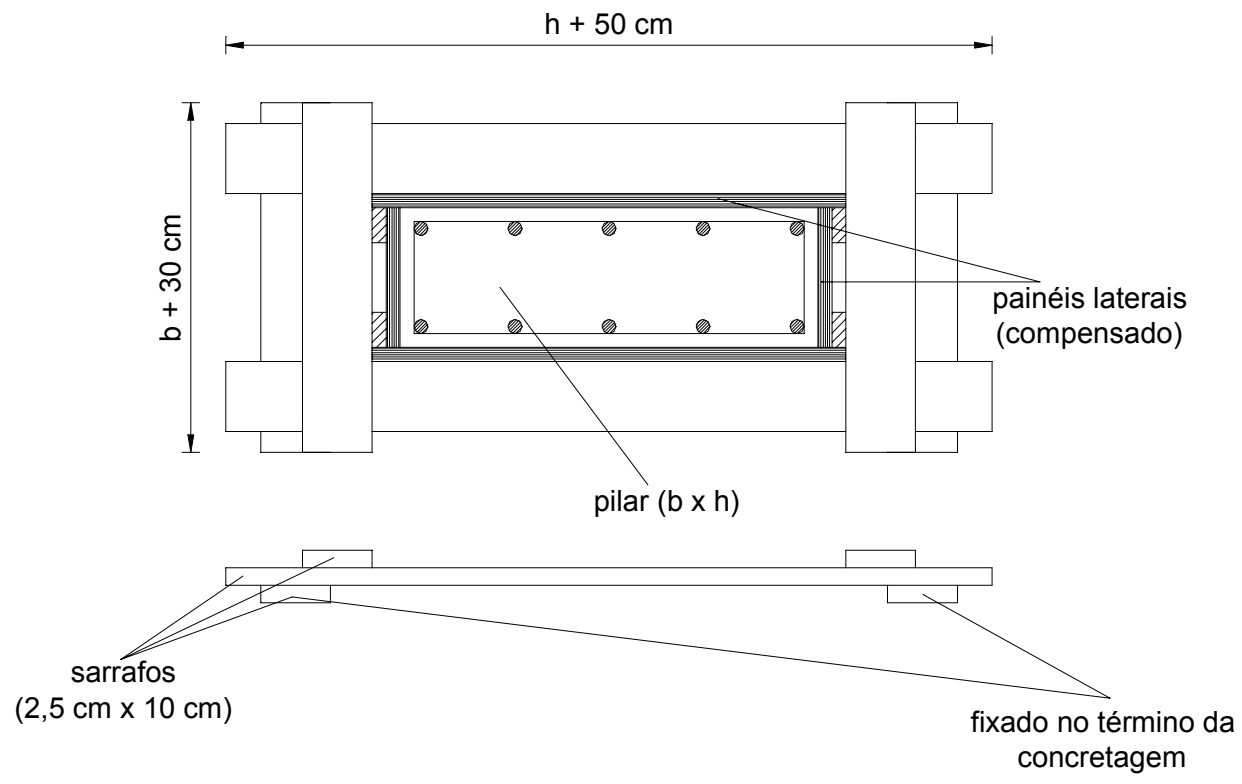

FIGURA 6.30 - Gastalho para a locação dos pilares 


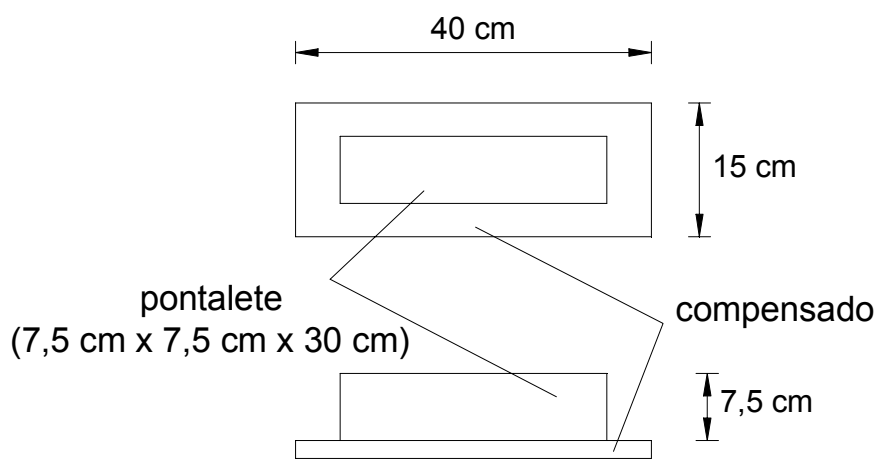

FIGURA 6.31 - Gastalho "maluco" para a fixação do contraventamento e prumagem dos pilares

Assim como os painéis das fôrmas para vigas, nas fôrmas para pilares, às vezes se faz necessário emendas entre painéis. $O$ procedimento é basicamente o mesmo, ilustrado pela FIGURA 6.16, também através de chapuz.

$\mathrm{Na}$ determinação do comprimento dos painéis das fôrmas para pilares é conveniente deixa uma folga de $2 \mathrm{~cm}$ entre a extremidade inferior do painel e o piso, para que possa ser feita a limpeza antes da concretagem, com jato d'água. Nos painéis externos dos pilares extremos, faz se o mesmo avançar em $10 \mathrm{~cm}$, para que haja uma melhor estanqueidade na fôrma. A FIGURA 6.32, em seguida, ilustra as situações.

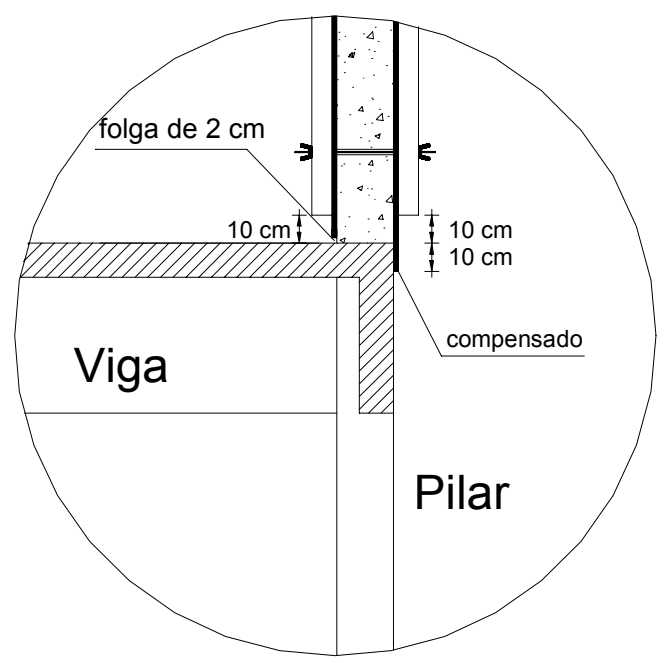

FIGURA 6.32 - Detalhe do prolongamento da chapa compensada nas fôrmas para pilares 


\subsection{Locação das fôrmas através de sistemas de eixos}

O sistema de eixos descrito a seguir foi desenvolvido por CARNEIRO (1995). O processo deve ser iniciado com a locação de piquetes, que servirão de guias para a elevação dos eixos principais. Para isso, tomam-se como referência as fundações e os pilares já dotados de armadura de arranque. Dois tipos de eixos são necessários para a amarração da laje, chamados de principais e secundários. $A$ locação dos eixos principais parte do piquete locado no andar térreo, por meio de um prumo de ponta seca, atividade que exige o trabalho de dois homens. Nesse momento, é importante que não haja incidência de ventos fortes, para que não haja deslocamentos do eixo transportado.

A FIGURA 6.33 exemplifica os possíveis deslocamentos dos eixos principais de cada pavimento em relação ao eixo vertical do edifício, na etapa de construção da estrutura. Nesta fase, os eixos principais devem ser amarrados em traves de madeira fixadas nas fôrmas das vigas de contorno do pavimento. Os eixos auxiliares deve ser amarrados em pregos fixados na borda da fôrma, a partir dos eixos principais.

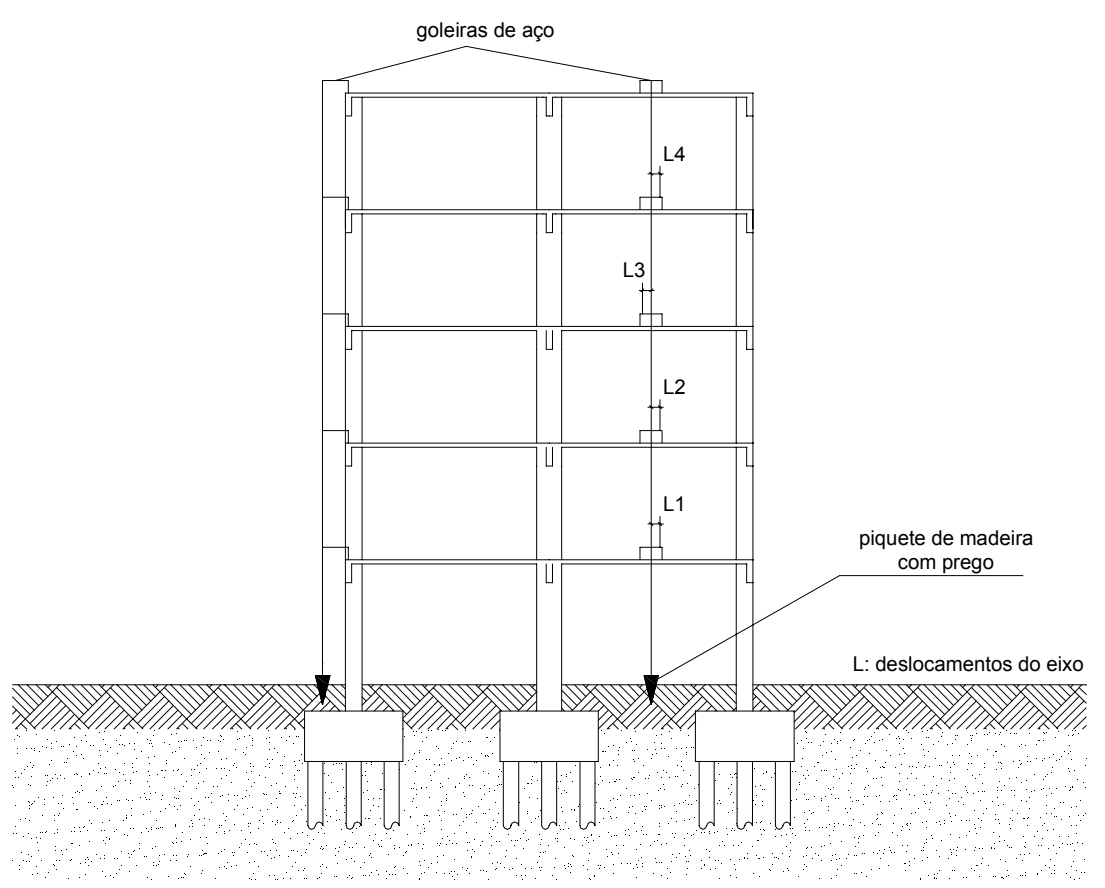

FIGURA 6.33 - Possíveis deslocamentos do eixo principal em relação ao eixo vertical 
A amarração das fôrmas das lajes deve ser feita com base no eixos auxiliares, após a verificação do esquadro em cada área formada por estes eixos. Feita a amarração das fôrmas, coloca-se a armadura. Antes da concretagem, devese fixar as goleiras de aço, que servirão para a nova elevação do eixo principal.

Passado o prazo de endurecimento do concreto da laje do primeiro pavimento, inicia-se a marcação dos gastalhos dos pilares da segunda laje. Isto é feito com o auxílio do sistema de eixos, transportando-se os eixos principais por meio do fio de prumo. Após a marcação dos gastalhos, deve-se checar o esquadro. $\mathrm{O}$ posicionamento dos gastalhos é feito com o apoio de duas medidas ( $\mathrm{x}$ e $\mathrm{y}$ ), marcadas a partir dos eixos principais até o centro, conforme FIGURA 6.34.

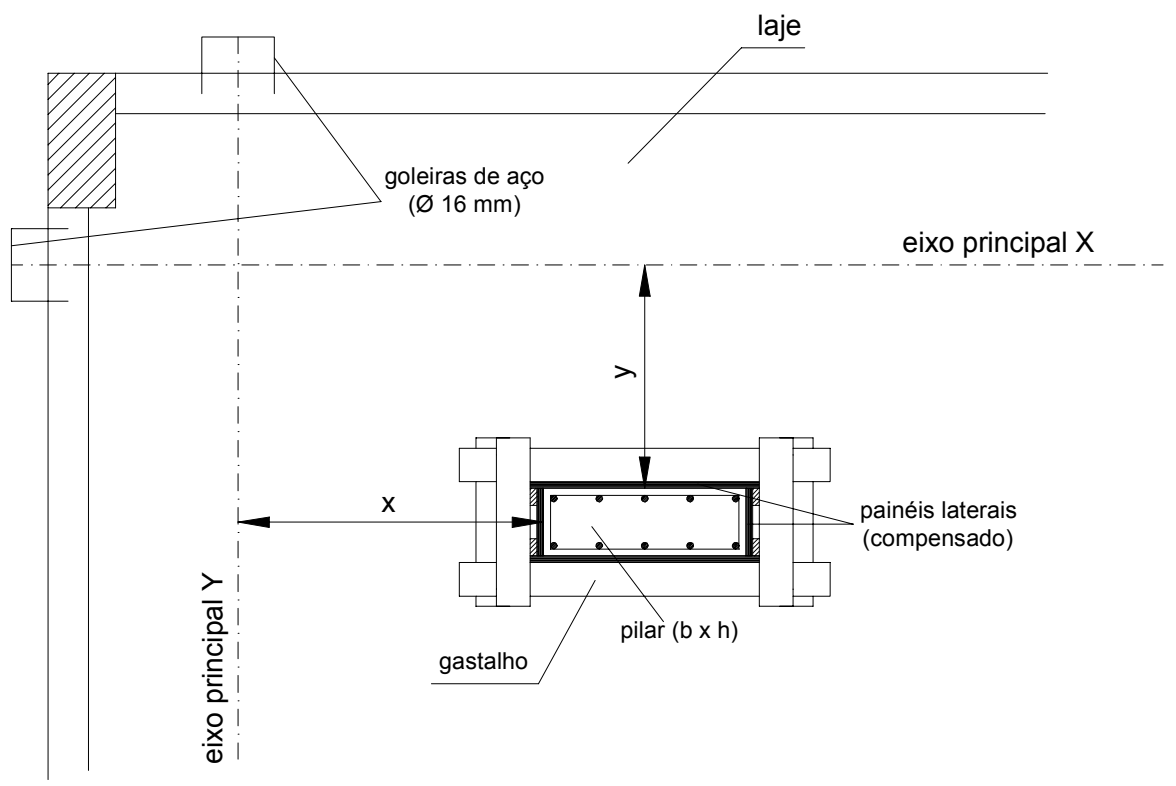

FIGURA 6.34 - Projeto de medidas para fixação dos gastalhos

Após a amarração dos gastalhos, segue-se com a colocação das fôrmas de pilares e vigas e a montagem das fôrmas de laje do segundo pavimento. Para a amarração das fôrmas da laje, o procedimento é o mesmo do realizado no pavimento inferior.

A grande vantagem do sistema de eixos é permitir correções durante a execução da parte estrutural da edificação. Se após a execução de um pavimento verificar-se, por exemplo, um afastamento da prumada vertical por abertura de uma fôrma, segmento desse pilar será corrigido a partir da locação dos gastalhos. 
Portanto, algumas vezes, os gastalhos poderão ficar salientes em relação às vigas de contorno ou de borda da laje.

Os pontos de marcação dos eixos principais devem ser definidos no projeto de fôrmas da estrutura.

Nas goleiras de aço deve-se marcar com uma serra o ponto de fixação do eixo principal, de modo a facilitar a elevação do eixo para o próximo pavimento. Durante a preparação das fôrmas da estrutura do pavimento seguinte, deve-se ter cuidado para que as escoras das vigas de borda não danifiquem as goleiras.

A cada três pavimentos executados deve-se proceder a um controle de verticalidade do edifício, para verificar se houve desnível considerável na geometria da estrutura.

\subsection{Elementos de pressão ou "moscas"}

Elementos de pressão (ou moscas) são elementos construtivos (compostos normalmente por tiras de chapas de madeira compensada) que, fixados nos extremos dos painéis permitem a desforma sem deteriorar o painel original. É o elemento de madeira que fica em contato direto com o concreto e fixado nos painéis de modo frágil. Desta maneira, ele pode ser destruído por ocasião da desforma, para a liberação dos painéis. A FIGURA 6.35 ilustra a representação em planta da posição de uma mosca no encontro entre duas vigas.



FIGURA 6.35 - Detalhe do elemento de pressão (ou "mosca") no encontro de duas vigas 
Verifica-se que as pontas dos painéis laterais não entram em contato direto com o concreto. Diz-se que a viga cujo painel chega mais próximo do concreto é a prioritária. A viga não prioritária é desformada primeiro.

\subsection{Método de Grundy e Kabaila para o escoramento e reescoramento das estruturas}

Um edifício em construção compõe um sistema estrutural que muda com o tempo. Além disso, como já comentado, o tempo altera as características de resistência e deformabilidade do concreto, mais acentuadamente nas idades iniciais.

Tanto a NBR-6118 (1978) quanto as normas internacionais não definem qualquer procedimento para determinação da distribuição das ações de construção nas estruturas de edifícios em concreto armado com múltiplos pavimentos.

HURD (1995) recomenda o método descrito por GRUNDY \& KABAILA (1963) para avaliar a distribuição das ações de construção.

Para utilizar o método simplificado há a necessidade de se definir o conceito de fatores de carga.

Os fatores de carga (k) expressam as ações de construção no pavimento ou nos pontaletes, sendo definidos como:

$$
\mathrm{k}=\frac{\text { ação atuante no pavimento (ou pontaletes) }}{\text { peso próprio do pavimento }}
$$

O método admite as seguintes hipóteses:

a) os pontaletes são considerados infinitamente rígidos em comparação com os pavimentos, no que se refere aos deslocamentos verticais;

b) os pontaletes estão posicionados suficientemente próximos entre si, de maneira que suas ações nos pavimentos podem ser consideradas como uniformemente distribuídas;

c) os valores das ações não dependem da velocidade de construção, uma vez que não são consideradas as diferentes idades do concreto;

d) a fundação é considerada como um suporte totalmente rígido; 
e) após a remoção das escoras, as fôrmas são retiradas permitindo-se a deformação do pavimento antes que qualquer reescora seja instalada;

f) os fatores de carga obtidos devem ser majorados ( 10\%) para levar em conta o peso próprio das fôrmas e pontaletes;

g) deve-se somar à máxima ação de construção obtida para pavimentos (ou pontaletes) um valor correspondente às seguintes ações variáveis: peso dos trabalhadores, equipamentos, materiais, entulhos e impacto produzido pelo lançamento do concreto.

A FIGURA 6.36 mostra os fatores de carga obtidos no caso de um processo de construção com dois níveis de escora mais dois níveis de reescora (2+2). 

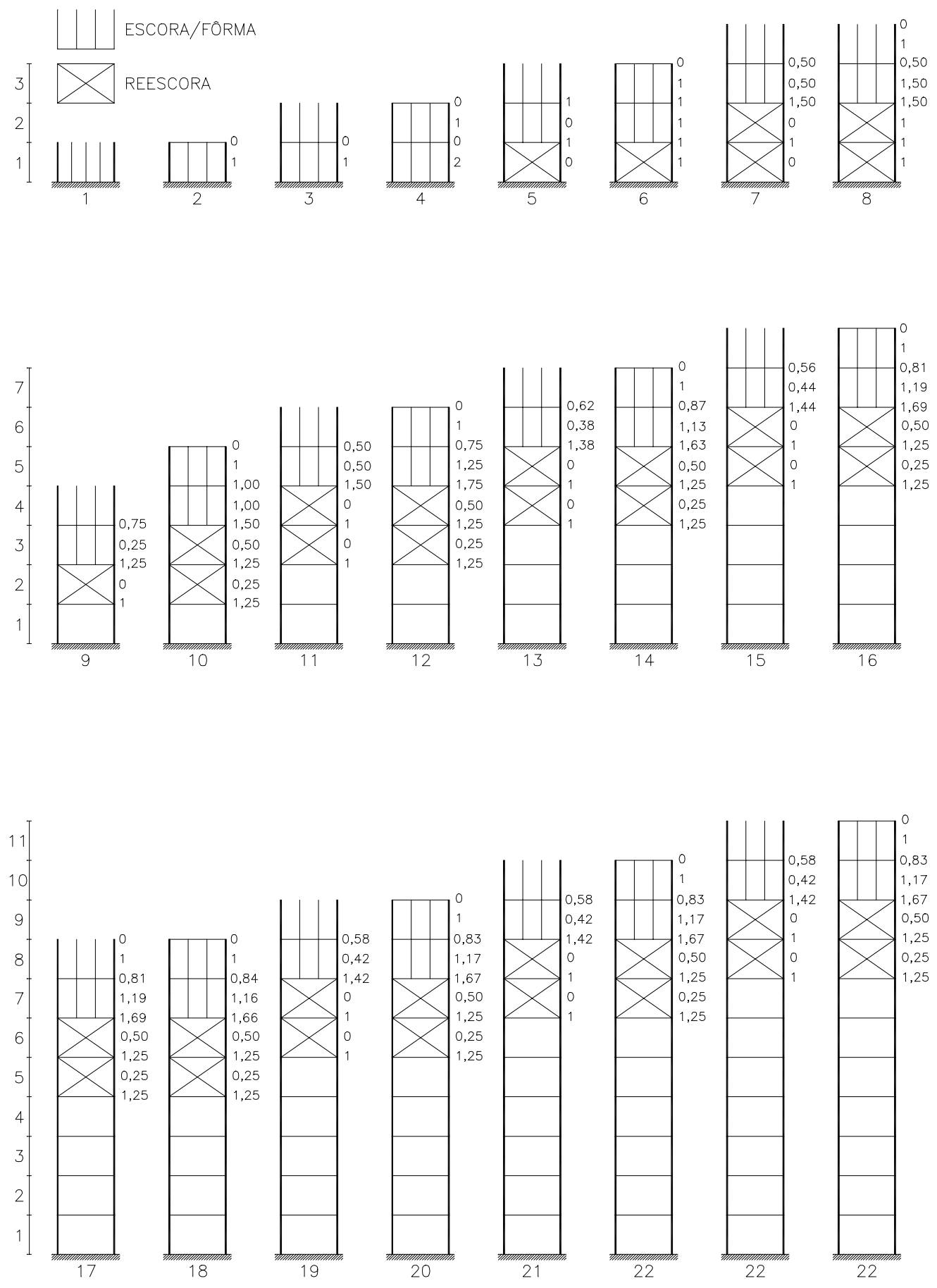

FIGURA 6.36 - Fatores de carga (k) para pavimentos e pontaletes $(2+2)$

$\mathrm{Na}$ operação (1) as escoras são instaladas, apoiando-se numa fundação rígida. Na operação (2) o primeiro pavimento é concretado, moldando-se nas fôrmas. O peso do concreto fresco é transmitido diretamente à fundação. 
Na operação (3) o segundo nível de escoras é instalado sobre o primeiro pavimento e então o segundo pavimento é concretado na etapa (4). Como as escoras do primeiro nível estão apoiadas sobre fundação rígida, o peso do segundo pavimento também é transmitido totalmente à base. Por hipótese o primeiro pavimento não se deforma, não recebendo portanto qualquer carga.

A operação (5) consiste na remoção das fôrmas e escoras do primeiro pavimento, que se deforma juntamente com o segundo pavimento. Satisfazendo o equilíbrio, o fator de carga (de valor 2) presente nas escoras removidas é distribuído igualmente entre os dois pavimentos do sistema de suporte. Ainda nesta operação, escoras são instaladas no terceiro nível e as reescoras são instaladas no primeiro nível, sem qualquer carga.

A operação (6) envolve a concretagem do terceiro pavimento, sendo a carga transmitida diretamente à fundação, já que os pavimentos não se deformam. $\mathrm{Na}$ operação (7) remove-se o nível mais baixo de fôrmas e escoras, com o fator de carga (de valor 1) sendo distribuído igualmente entre os dois pavimentos superiores. As ações nas escoras e reescoras são obtidas por equilíbrio. Ainda nesta operação, escoras são instaladas no quarto nível e reescoras são instaladas no segundo nível, sem qualquer carga.

Na operação (8) é feita a concretagem do quarto pavimento, sendo a carga transmitida diretamente à fundação, através dos pontaletes rígidos. A operação (9) envolve a remoção do nível mais baixo de fôrmas e escoras, com o fator (de carga de valor 1,50$)$ sendo distribuído igualmente entre os dois pavimentos superiores. Ainda nesta operação, as reescoras são retiradas do nível mais baixo e instaladas no terceiro nível (sem qualquer carga), enquanto simultaneamente escoras são instaladas no quinto nível. Os pavimentos abaixo do nível de fôrmas retirado suportam apenas o próprio peso. Por equilíbrio obtém-se as ações nas escoras e reescoras.

$\mathrm{Na}$ operação (10) é concretado o quinto pavimento, sendo a carga distribuída igualmente entre os pavimentos que formam o sistema de suporte. Novamente, as ações e reescoras são obtidas por equilíbrio.

A operação (11) repete a seqüência da operação (9), e assim por diante até ocorrer a convergência dos valores dos fatores de carga para pavimentos e pontaletes.

A FIGURA 6.37 mostra os fatores de carga máximos para cada pavimento, indicando uma convergência de valores relativamente rápida. 




FIGURA 6.37 - Fatores de cargas máximos para cada pavimento

Pode-se notar que a ação de construção mais elevada ocorre no quarto pavimento $(K=1,75)$, durante a operação (12).

Já em relação aos pontaletes, o nível mais solicitado é o apoiado diretamente na fundação rígida $(\mathrm{K}=2)$, durante a operação (4).

Através do método simplificado pode-se estabelecer para cada pavimento um diagrama de fatores de carga. A FIGURA 6.38 ilustra o diagrama obtido para o quarto pavimento.

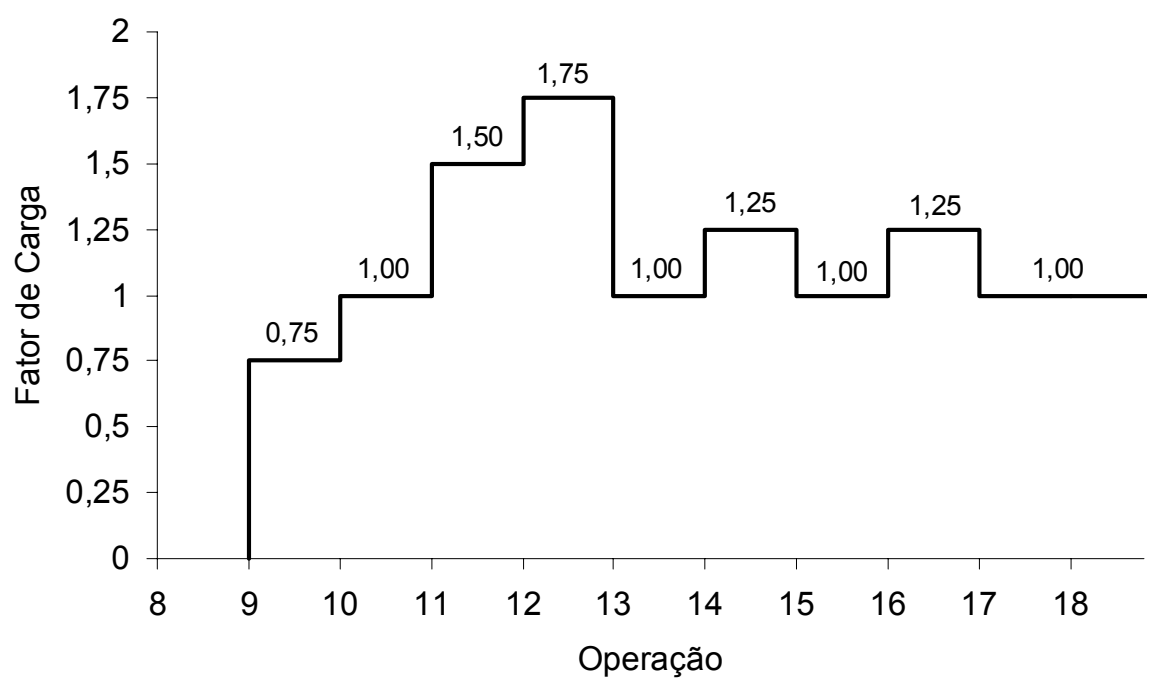


FIGURA 6.38 - Diagrama de fatores de carga para o quarto pavimento

Este diagrama define a história de carregamentos construtivos do quarto pavimento. Deve-se lembrar, ainda, de duas indicações do método. A primeira delas se refere à majoração dos fatores de carga, a fim de levar em conta o peso próprio das fôrmas e pontaletes. A segunda se refere à adição à máxima ação de construção de um valor referente às ações variáveis já citadas. Por exemplo, será feita uma majoração de $10 \%$ nos fatores de carga e, para considerar as referidas ações variáveis, somado o valor de $(2,64 / \mathrm{N}) \mathrm{kN} / \mathrm{m}^{2}$ ao patamar da máxima ação de construção, nesse caso. O número de pavimentos do sistema de suporte $(\mathrm{N})$ é igual a quatro, e o valor adicionado será de $0,66 \mathrm{kN} / \mathrm{m}^{2}$.

A FIGURA 6.39 mostra a história de carregamentos construtivos do quarto pavimento assim obtida, supondo que este tenha um peso próprio de $3,5 \mathrm{kN} / \mathrm{m}^{2}$.

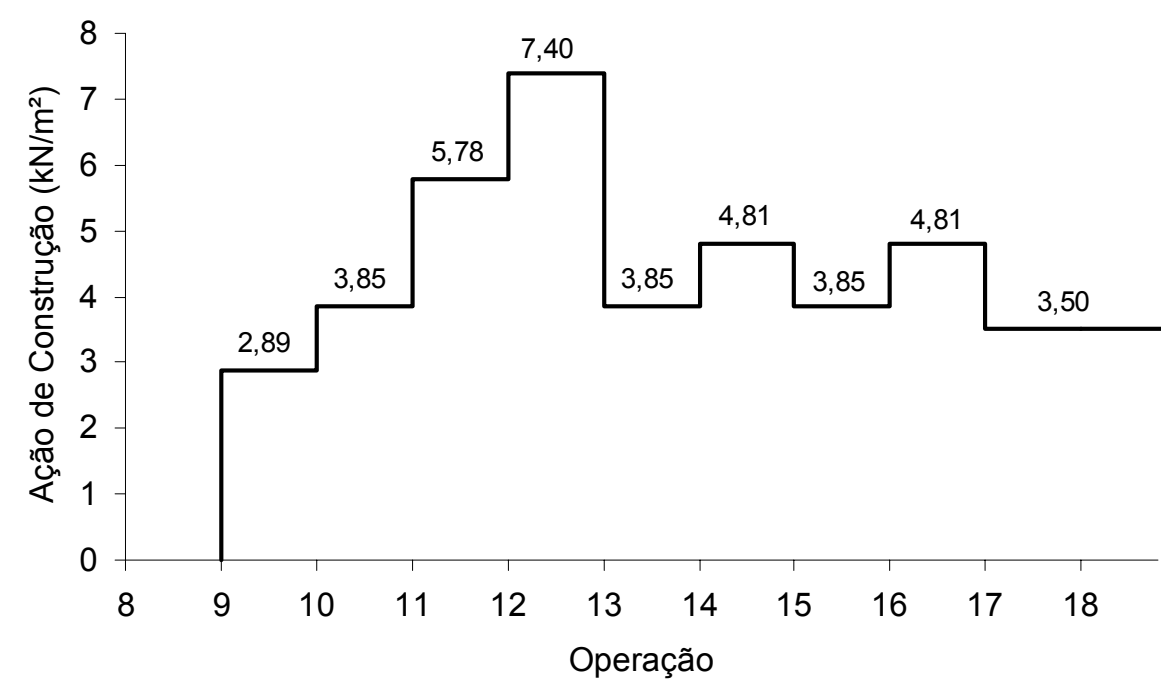

FIGURA 6.39 - História de carregamentos construtivos para o quarto pavimento

A TABELA 6.2 mostra os valores máximo e convergente para os fatores de carga nos pavimentos, admitindo processos de construção combinados de até três níveis de escoras com até cinco níveis de reescoras.

Os resultados da TABELA 6.2 mostram que, considerando as hipóteses do método, é preferível utilizar somente um nível de escoras e quantos níveis de reescoras forem possíveis para minimizar as ações de construção nos pavimentos. 
TABELA 6.2 - Valores máximos e convergente dos fatores de carga para os pavimentos

\begin{tabular}{c|c|c|c|c|c|c|c}
\hline \multirow{2}{*}{$\begin{array}{c}\text { Número de Níveis } \\
\text { de Escoras }\end{array}$} & \multicolumn{7}{|c}{ Fatores de Cargas Máxima e Convergente } \\
\cline { 3 - 8 } \multicolumn{2}{c}{} & \multicolumn{7}{|c}{ Número de Níveis de Reescoras } \\
\cline { 3 - 8 } \multicolumn{2}{c|}{$\mathbf{0}$} & $\mathbf{1}$ & $\mathbf{2}$ & $\mathbf{3}$ & $\mathbf{4}$ & $\mathbf{5}$ \\
\hline 1 & Máximo & 2,00 & 1,50 & 1,33 & 1,25 & 1,20 & 1,17 \\
\cline { 2 - 8 } & Convergente & 2,00 & 1,50 & 1,33 & 1,25 & 1,20 & 1,17 \\
\hline 2 & Máximo & 2,25 & 1,83 & 1,75 & 1,67 & 1,59 & 1,54 \\
\cline { 2 - 8 } & Convergente & 2,00 & 1,77 & 1,67 & 1,60 & 1,55 & 1,52 \\
\hline 3 & Máximo & 2,38 & 2,21 & 1,98 & 1,84 & 1,78 & 1,78 \\
\cline { 2 - 8 } & Convergente & 2,00 & 1,87 & 1,83 & 1,77 & 1,72 & 1,72 \\
\hline
\end{tabular}

Embora os resultados apresentados neste capítulo devam ser respeitados, há a necessidade de se melhor estudar o assunto, por exemplo no que se refere a algumas hipóteses adotadas. ALMEIDA PRADO (1999) define um modelo de análise das etapas de construção que se aproxima mais do comportamento real da estrutura, permitindo até ser avaliada a confiabilidade do Método de Grundy e Kabaila.

Segundo ALMEIDA PRADO (1999) os pontaletes seriam infinitamente rígidos e todos os pavimentos do sistema de suporte teriam as mesmas características de resistência e deformabilidade.

Quanto à primeira hipótese, o mesmo diz que sua adoção prejudica os resultados. Enquanto o primeiro nível de pontaletes (apoiado em fundação rígida) não é retirado, todas as ações de lajes concretadas caminham diretamente para a fundação através dos mesmos. Absolutamente isso não condiz com a realidade. Está claro que, como os pontaletes são axialmente deformáveis, parte das ações de um pavimento recém concretado é absorvida pelos pavimentos inferiores do sistema de suporte.

Já a segunda hipótese significa não considerar a idade do concreto na determinação da distribuição das ações de construção. Ao tomar todos os pavimentos do sistema de suporte com a mesma rigidez (independentemente da idade de cada um), necessariamente a distribuição das ações não vai depender da 
velocidade de construção, mas somente do número de níveis de escoras e reescoras.

Outro ponto discutido por ALMEIDA PRADO (1999) é a consideração das ações nos pavimentos como distribuídas, uma vez que os pontaletes do sistema de suporte podem aparecer em pequeno número e muito espaçados entre si.

Além disso, o Método de Grundy e Kabaila ainda despreza a absorção de carga por parte dos pilares, na concretagem de um pavimento.

No que se refere à fissuração que ocorre durante a construção, esta altera a distribuição das ações entre os pavimentos. SBAROUNIS (1984) relata que a incorporação desse efeito deve reduzir os valores das máximas ações de construção. Se assim for, os valores das máximas ações de construção obtidos sem a consideração da fissuração representam um limite superior para os resultados.

\subsection{Cura e prazos de retirada das fôrmas}

As ações que atuam nos pavimentos durante a construção podem ultrapassar as ações em serviço consideradas em projeto. Alem disso, as ações de construção normalmente solicitam o concreto antes que o mesmo tenham atingido as características de resistência e deformabilidade previstas, aos 28 dias.

A preocupação com esse carregamento prematuro se torna cada vez maior na medida em que, nos últimos anos, tem-se assistido a uma tendência de aceleração do processo e construção dos edifícios em concreto armado.

Segundo SHEHATA et al. (1993) a revisão da NBR 6118 (1978) deve indicar o uso da TABELA 6.3 para a resistência à compressão, na ausência de dados mais precisos.

TABELA 6.3 - Relações $\mathrm{f}_{\mathrm{c}}(\mathrm{t}) / \mathrm{f}_{\mathrm{c} 28}$, para $21^{\circ} \mathrm{C}<\mathrm{T}<30^{\circ} \mathrm{C}$

[Fonte: SHEHATA et al. (1993)]

\begin{tabular}{c|c|c|c}
\hline $\mathrm{f}_{\mathrm{c} 28}(\mathrm{MPa})$ & 3 dias & 7 dias & 91 dias \\
\hline 18 & 0,34 & 0,50 & 1,26 \\
\hline 23 & 0,36 & 0,61 & 1,25 \\
\hline 28 & 0,42 & 0,66 & 1,20 \\
\hline 35 & 0,49 & 0,71 & 1,16 \\
\hline 43 & 0,54 & 0,74 & 1,14 \\
\hline
\end{tabular}


Em relação ao módulo de elasticidade a nova norma [NBR 6118 (1978)] deve estabelecer, ainda segundo SHEHATA et al. (1993), a expressão a seguir.

$E_{c}(t)=\sqrt{\frac{f_{c}(t)}{f_{c 28}}} E_{c 28} \quad$ para $21^{\circ} \mathrm{C}<T<30^{\circ} \mathrm{C}$

A pega e o endurecimento do concreto são muito influenciados pelo tipo de cimento, temperatura ambiente e condições de cura. O aumento da resistência e do módulo de elasticidade não estão limitados apenas ao período de 28 dias, como pode-se perceber pela TABELA 6.3 e pela EQUAÇÃO 6.5 .

Quanto ao tempo de cura necessário há controvérsias na literatura, sendo que a NBR 6118 (1978) especifica um período mínimo de 7 dias.

Para mostrar a influência do tempo de cura no desenvolvimento da resistência à compressão, o gráfico da FIGURA 6.40 indica curas de 3, 7 e 14 dias consecutivos. Os dados foram obtidos em ensaios e adaptados de LEVY \& HELENE (1996). Foram consideradas condições normais de cura úmida e temperatura de $20^{\circ} \mathrm{C}$.



FIGURA 6.40 - Desenvolvimento da resistência à compressão do concreto para diferentes tempos de cura úmida [Fonte: LEVY \& HELENE (1996)]

Segundo o gráfico anterior pode-se notar um decréscimo de aproximadamente $15 \%$ na resistência à compressão aos 28 dias quando, ao invés 
de 7 dias, procede-se à cura durante somente 3 dias. Já quando a cura é feita por 14 dias consecutivos há um acréscimo de cerca de $10 \%$.

De acordo com LEVY \& HELENE (1996) a partir de 14 dias não há mais nenhum ganho substancial de resistência aos 28 dias, por mais tempo que o concreto permaneça em condições normais de cura úmida.

A verdade é que, enquanto não atingir endurecimento satisfatório, o concreto deverá ser protegido contra agentes prejudiciais, tais como, mudanças bruscas de temperatura, secagem, chuva forte, água torrencial, agente químico, bem como contra choques e vibrações de intensidade tal que possa produzir fissuração no concreto ou prejudicar sua aderência à armadura.

Quanto aos prazos de retirada das fôrmas e do escoramento a norma NBR 6118 (1978), em fase de revisão, prescreve:

"A retirada das fôrmas e do escoramento só poderá ser feita quando o concreto se achar suficientemente endurecido para resistir às ações que sobre eles atuarem e não conduzir a deformações inaceitáveis, tendo em vista o valor baixo do módulo de elasticidade $E_{c}$ e a maior probabilidade de grande deformação lenta quando o concreto é solicitado com pouca idade.

Se não for demonstrado o atendimento das condições acima, e não se tendo usado cimento de alta resistência inicial ou processo que acelere o endurecimento, a retirada das fôrmas e do escoramento não deverá dar-se antes dos seguintes prazos:

- faces laterais: 3 dias;

- faces inferiores, deixando-se pontaletes bem encunhados e convenientemente espaçados: 14 dias;

- faces inferiores, sem pontaletes: 21 dias”.

Entretanto, a NBR 7678 (1983) recomenda os seguintes tempos mínimos de cura convencional antes da desfôrma, dados na TABELA 6.4.

TABELA 6.4 - Prazo de desfôrma segundo a NBR 7678 (1983)

\begin{tabular}{l|c|c}
\hline \multirow{2}{*}{ Tipo de peça estrutural } & \multicolumn{2}{|c}{ Quando a sobrecarga for: } \\
\cline { 2 - 3 } & $\begin{array}{l}\text { maior que o peso próprio } \\
\text { do concreto e das fôrmas }\end{array}$ & $\begin{array}{c}\text { menor que o peso próprio } \\
\text { do concreto e das fôrmas }\end{array}$ \\
\hline Arcos & 14 dias & 7 dias \\
\hline
\end{tabular}




\begin{tabular}{|c|c|c|}
\hline $\begin{array}{l}\text { Fundo de vigas de menos } \\
\text { de } 3 \mathrm{~m} \text { de vão }\end{array}$ & 7 dias & 4 dias \\
\hline $\begin{array}{l}\text { Fundo de vigas de vão } \\
\text { entre } 3 \mathrm{~m} \mathrm{e} 6 \mathrm{~m}\end{array}$ & 14 dias & 7 dias \\
\hline $\begin{array}{l}\text { Fundo de vigas de mais } \\
\text { de } 6 \mathrm{~m} \text { de vão }\end{array}$ & 21 dias & 14 dias \\
\hline $\begin{array}{l}\text { Lajes com vãos menores } \\
\text { que } 3 \mathrm{~m}\end{array}$ & 4 dias & 3 dias \\
\hline $\begin{array}{l}\text { Lajes com vãos entre } 3 \mathrm{~m} \\
\text { e } 6 \mathrm{~m}\end{array}$ & 7 dias & 4 dias \\
\hline $\begin{array}{l}\text { Lajes com vãos maiores } \\
\text { que } 6 \mathrm{~m}\end{array}$ & 10 dias & 7 dias \\
\hline Paredes & 1 dia & 1 dia \\
\hline Colunas & 1 dia & 1 dia \\
\hline Fôrmas laterais de vigas & 1 dia & 1 dia \\
\hline $\begin{array}{l}\text { Lajes protendidas com } \\
\text { aderência posterior }\end{array}$ & \multicolumn{2}{|c|}{ assim que for aplicada a protensão fina } \\
\hline
\end{tabular}

Os tempos da tabela anterior, poderão ser reduzidos quando forem utilizados aceleradores químicos ou físicos da cura, sob supervisão de profissional habilitado.

As normas espanholas [MONTOYA (1987)] recomendam para a desfôrma das faces laterais de elementos de concreto armado, com processo de endurecimento normal, os seguintes prazos:

TABELA 6.5 - Prazo de desfôrma das faces laterais

\begin{tabular}{l|c|c}
\hline \multicolumn{1}{c|}{ Tipo de Cimento } & $\begin{array}{c}\text { Faces Laterais } \\
\text { de Vigas }\end{array}$ & $\begin{array}{c}\text { Faces Laterais } \\
\text { de Pilares }\end{array}$ \\
\hline Portland Comum & 3 dias & 7 dias \\
\hline Portland de Alta Resistência Inicial & 2 dias & 4 dias \\
\hline
\end{tabular}

Para as faces de fundo das lajes e vigas, bem como para o escoramento, a desfôrma deverá ser efetuada quando decorrer o tempo mínimo para que o 
concreto alcance a resistência necessária para suportar o dobro dos esforços que aparecerão no momento da retirada.

Para o cimento Portland Comum podem ser tomados os seguintes prazos, em dias, de acordo com a TABELA 6.6.

TABELA 6.6 - Prazo de desfôrma nas faces de fundo de lajes, vigas e escoramento

\begin{tabular}{c|c|c|c|c}
\hline \multirow{2}{*}{$\mathbf{P}$} & \multicolumn{4}{|c}{$\mathbf{T}_{\mathbf{m}}$} \\
\cline { 2 - 5 } & $\mathbf{5}^{\circ}$ & $\mathbf{1 0}^{\circ}$ & $\mathbf{1 5}^{\circ}$ & $\mathbf{2 0}^{\circ}$ \\
\hline 0 & 56 & 42 & 34 & 28 \\
\hline 0,5 & 27 & 20 & 16 & 14 \\
\hline 1,0 & 18 & 13 & 11 & 9 \\
\hline
\end{tabular}

Onde:

P é a ação permanente na desfôrma;

F é a ação variável prevista na desfôrma;

$\mathrm{T}_{\mathrm{m}} \quad$ é a média aritmética das máximas e mínimas temperaturas diárias.

Para outro tipo de cimento Portland e outras sobrecargas podem ser empregados prazos de desfôrma dados pela expressão da EQUAÇÃO 6.6, dada em seguida.

$$
\mathrm{n}=\frac{280 \cdot \mathrm{u}_{\mathrm{c}}}{\left(\frac{\mathrm{F}}{\mathrm{P}}+\frac{\mathrm{u}_{\mathrm{c}}}{3}\right) \cdot\left(\mathrm{T}_{\mathrm{m}}+10\right)}
$$

Onde:

n é o prazo de desfôrma das faces de fundo de lajes, vigas e escoramento, em dias;

$\mathrm{u}_{\mathrm{c}} \quad$ é a relação $\mathrm{f}_{\mathrm{ck}} / \mathrm{f}_{\mathrm{ck} 07}$ entre a resistência característica exigida para o concreto no projeto e a correspondente aos 7 dias.

\subsection{Operações de montagem e desfôrma}

Para as operações de montagem e desfôrma será seguido o procedimento definido por ALMEIDA JÚNIOR (1996). A montagem de um sistema de fôrmas 
obedece um cronograma lógico e que pode ser sintetizado nas seguintes etapas: recebimento das fôrmas, locação e montagem dos gastalhos, montagem das fôrmas dos pilares, montagem das fôrmas das vigas e montagem das fôrmas das lajes.

Os procedimentos a serem seguidos no recebimento das fôrmas devem ser efetuados tanto quando forem fornecido, o sistema de fôrmas, por uma empresa terceirizada, como quando o mesmo for de fabricação própria, seja por uma central ou até mesmo no canteiro. No recebimento das fôrmas deve-se prever um local para armazenamento, sendo este fora da área de montagem, numerando e organizando de acordo com a seqüência de montagem. Deve-se, através de uma listagem, conferir as peças, para que não haja falhas na montagem. Para a armazenagem das peças, deve-se montar uma plataforma e cobrir com lona plástica até sua utilização, evitando ao máximo o contato de água com as peças; úmidas elas aumentam de peso e incham, podendo prejudicar seu perfeito encaixe. Todas as peças devem receber uma aplicação de desmoldante na superfície que ficará em contato com o concreto, bem como, a aplicação de uma tinta selante nas bordas das mesmas, para evitar a entrada de água entre as lâminas do compensado.

Inicialmente, através do sistema de eixos apresentado anteriormente, devese locar os gastalhos para a montagem das fôrmas dos pilares.

Com a armadura do pilar colocada juntamente com as pastilhas de recobrimento, inicia-se a colocação dos painéis dos pilares, fechando e travando-os com as guias ou gravatas de amarração. A montagem do pilar deverá ser liberada somente com a verificação do prumo, nivelando a mesma e travando-a através de peças de contraventamento.

A montagem das fôrmas das vigas começa quando os painéis dos pilares estão devidamente montados e conferidos. Inicia-se com a locação das escoras (garfos) das vigas nos respectivos alinhamentos e espaçamentos previstos em projeto, contraventando-as lateralmente com mão-francesas. Coloca-se pois, os painéis de viga sobre as escoras (podendo ser garfos). Em seguida confere-se o espaçamento, batendo as cunhas entre as escoras e piso, para nivelar o fundo das mesmas. O travamento e alinhamento lateral das vigas só será realizado após a colocação dos painéis de laje.

Montadas as fôrmas das vigas, parte-se para a montagem das fôrmas das lajes colocando as guias sobre as escoras das vigas (garfos) para apoio das 
longarinas e transversinas. Após a colocação das transversinas e longarinas encaixe-se as escoras, contraventando-as lateralmente. Então, posiciona-se os painéis de laje sobre as transversinas ou longarinas conforme a paginação definida no projeto de fôrmas. Em seguida nivela-se a laje, batendo as cunhas sob as escoras, alinha-se as faces laterais das vigas, conferindo sua geometria e batendo cunhas para travar os painéis.

Deve-se conferir o contraventamento lateral de todo o sistema de fôrmas, para evitar a hipostaticidade do conjunto. Em seguida limpa-se todo o assoalho da laje, as fôrmas das vigas e dos pilares. Concretam-se os pilares até $5 \mathrm{~cm}$ abaixo da face de fundo das fôrmas das vigas.

O próximo passo é fazer toda a locação e montagem dos elementos hidráulicos e elétricos que não interferem na armação. Então, arma-se as vigas e as lajes, terminando com a montagem das instalações e concretagem das vigas e lajes. Não esquecer de deixar a goleira de aço para a transferência do sistema de eixos.

A desfôrma deve-se proceder com a retirada do escorameto das vigas e lajes, reescorando as mesmas conforme o projeto. Retira-se então, as faces dos pilares, as faces das vigas, o assoalho da laje e o fundo das vigas. Na retirada dos painéis, deve ser iniciado pelos de menores dimensões, por serem de mais fácil desfôrma. No caso do assoalho da laje deve-se iniciar pela abertura de desfôrma que será prevista no projeto. Para evitar a queda das placas de compensado diretamente no piso, quebrando as quinas e deteriorando as chapas, monta-se uma rede de cordas, ou qualquer outra alternativa. No caso de peças que se mantenham pregadas, com dificuldades de desfôrma, deve-se utilizar cunhas de madeira para facilitar.

Todos os painéis devem ser limpos, removendo o excesso de nata e argamassa aderidos à superfície e bordas das chapas de madeira compensada, recuperando as que estiverem danificadas, e então, aplica-se selante nas bordas. Por fim encaminhar os painéis para o piso superior em perfeito estado de conservação para nova utilização.

Todo o procedimento descrito anteriormente foi pensando num sistema de fôrmas, onde a madeira preponderava. Quando se tratar de peças metálicas e industrializadas deve-se, também, ater às recomendações de montagem e desfôrma do fabricante. 


\subsection{Considerações finais}

Apresentou-se informações e dados para o bom manuseio da fôrmas. Mostrou-se algumas disposições construtivas para os subsistemas de fôrmas para pilares, vigas e lajes, bem como a definição da seqüência de montagem, desfôrma, cuidados a tomar, enfim, são as informações, não contidas no projeto, mas fundamentais para a execução das fôrmas.

As recomendações contidas nesse capítulo seguem um raciocínio lógico, elementar e básico, porém completo. Na sua elaboração procurou-se servir da experiência, obtida ao longo de muitos anos, de profissionais que se especializaram no assunto, cujo elemento é mais rico e completo.

Todavia, as maiores dificuldades da obra tem-se mostrado na fase de execução, exatamente pela falta de profissionalismo dos operários, tendendo-se geralmente, para o improviso. Torna-se importante pois, uma série de verificações, através de um rigoroso controle de execução, com a finalidade de minimizar os erros ou detectá-los prematuramente, isto é, antes que eles sejam consumados.

Desta maneira, torna-se clara a importância das relações entre as equipes de projeto e construção para garantir a segurança e as condições de utilização da estrutura. 


\section{Projeto de FôRmas}

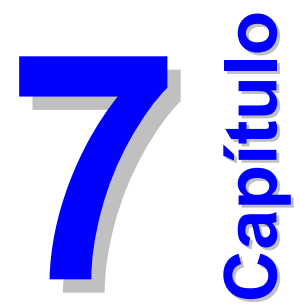

\subsection{Generalidades}

Em um mercado mais competitivo, a busca por qualidade é fator primordial para a sobrevivência das empresas, assim como o domínio da tecnologia é fundamental para o desenvolvimento de novos modos de atuação das mesmas.

Dentro desse enfoque, nos últimos anos, as empresas de construção civil vêm buscando mecanismos para o aumento da sua eficiência, com o objetivo de atingir um patamar mais elevado de qualidade, com reduções de custos.

Entre os vários fatores que podem levá-los a alcançar o seu o objetivo, deve-se destacar a integração e participação de todos os envolvidos no processo de produção dos empreendimentos. Dessa forma, o projeto passa a ser uma importante ferramenta, a partir do instante em que ele tem a função de garantir a integração entre a concepção dos produtos e sua produção.

Atingir um patamar diferenciado de qualidade tem sido um desafio para a maioria das empresas de construção civil. Entre vários obstáculos, encontra-se a dificuldade de alterar o modo de projetar, uma vez que o trabalho não sistematizado 
e descoordenado das equipes responsáveis pelo desenvolvimento do projeto se faz muito presente nos dias e hoje, resultando na ausência de um projeto verdadeiramente voltado à produção.

Os projetos devem ser elaborados a partir de programas claros, bem definidos e corretamente dimensionados. Devem ser desenvolvidos em etapas que permitam avaliações e aferições intermediárias. O conteúdo de um projeto completo deve ser o mais abrangente possível, de sorte a permitir a verificação e coordenação de todas as interfaces entre as diversas especialidades de cada projeto, a identificação dos processos e métodos construtivos, especificação e quantificação de todos os elementos que constituem a obra, permitindo, portanto, cronogramas e planejamento de obras mais coerentes, otimizando os recursos financeiros.

O projeto deve ser visto como uma antecipação da produção, ou seja, envolvendo informações sobre a tecnologia adotada, métodos construtivos, organização da produção e controle da qualidade, de modo a resolver os problemas básicos da atividade de produção em canteiro, conciliando assim as necessidades do produto (sistema de fôrmas) a da produção (o processo).

Em seguida são apresentadas regras gerais de elaboração do projeto e desenhos de fôrmas baseados nas recomendações da NBR 10067 (1995).

\subsection{Simbologia e terminologia para o projeto de fôrmas}

Os desenhos de conjunto do projeto de um sistema de fôrmas, ou seja, desenhos utilizados para representar o arranjo geral por meio de plantas, devem ser feitos em escalas adequadas ao tamanho da obra a ser representada, para que não haja dúvidas na identificação das partes, recomenda-se o emprego da escala $1: 50$.

Nos desenhos de detalhes, utilizados para representar minúcias necessárias à execução e arranjo de componentes, estes podendo ser plantas, elevações, seções e cortes, recomenda-se as escalas: 1:1, 1:5, 1:10 e 1:20.

Os painéis de vigas e pilares são identificados por letras (A, $B, C$...) a FIGURA 7.1, em seguida, apresenta uma possível convenção a ser adotada nos projetos, a FIGURA 7.2 exemplifica. 




FIGURA 7.1 - Convenção para nomenclatura de painéis de fôrmas

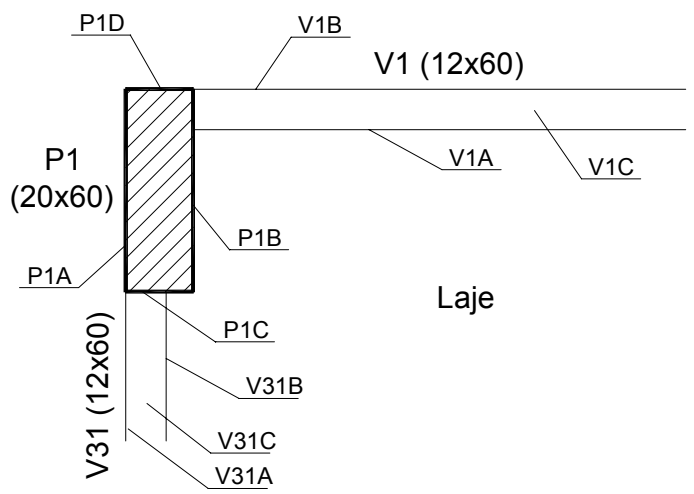

FIGURA 7.2 - Exemplo de nomenclatura para uma estrutura qualquer

As linhas a serem utilizadas são identificadas pela espessura e forma. $\mathrm{Na}$ TABELA 7.1, em seguida, estão representadas as aplicações mais importantes dos tipos de linhas empregadas nos projetos de fôrmas. 
TABELA 7.1 - Simbologia para o desenho no projeto de fôrmas

\begin{tabular}{|c|c|}
\hline Tipos de linhas & Aplicações mais importantes \\
\hline Linha cheia & $\begin{array}{l}\text { Contorno de superfícies cortadas, contorno } \\
\text { de compensado ou sarrafo, vistas em } \\
\text { primeiro plano (ou de frente), etc. }\end{array}$ \\
\hline $\begin{array}{l}\text { Linha tracejada } \\
--------\end{array}$ & $\begin{array}{l}\text { Contorno de compensado ou sarrafo vistos } \\
\text { em segundo plano (arestas invisíveis), etc. }\end{array}$ \\
\hline $\begin{array}{l}\text { Linha traço ponto } \\
------\end{array}$ & Linhas de centro, eixos, etc. \\
\hline Linha à mão livre & $\begin{array}{l}\text { Linha de pequenas separações e limites de } \\
\text { vistas e seções parciais ou interrompidas, } \\
\text { etc. }\end{array}$ \\
\hline $\begin{array}{c}\text { Hachura } \\
\text { WWN }\end{array}$ & Sarrafo ou compensado resinado, etc. \\
\hline
\end{tabular}

\subsection{Composição de um projeto de fôrmas}

O planejamento das fôrmas busca determinar o que fazer, onde fazer e quando fazer. Nesta etapa apresenta-se idéias de métodos construtivos e os possíveis sistemas escolhidos, uma previsão do custo unitário, uma previsão do volume total de serviços, índices de mão de obra e uma estimativa de tempo para execução. O projeto busca estabelecer como fazer. Consiste no conjunto de elementos que permitem elucidar junto ao pessoal encarregado de executá-lo, todos os detalhes de como executar as fôrmas, sempre com desenhos simples, claros e completos.

Em seguida é apresentada a composição de um projeto de fôrmas, sendo composto de:
a) Relatório explicativo;
b) Desenhos dos Painéis de Pilares;
c) Desenhos dos Painéis de Vigas;
d) Desenhos dos Garfos;
e) Planta de Paginação dos Painéis de Lajes;
f) Planta de Locação de Longarinas e Escoras;
g) Planta de Montagem dos Painéis de Vigas; 
h) Planta de Locação de Garfos e Pontaletes;

i) Planta de Locação de Pontaletes e Faixas para Reescoramento de Lajes;

j) Planta de Locação de Pontaletes e Faixas para Reescoramento de Vigas;

k) Plano de Corte

\section{a) Relatório explicativo}

No relatório explicativo constam todos os dados do projeto. Os painéis de pilares, vigas e garfos são descritos minuciosamente. É mostrada como deverá ser a utilização das plantas auxiliares, assim como a seqüência a ser aplicada na obra para a execução do projeto de fôrma.

Também estão inseridas as seguintes tabelas:

- quantitativos de garfos por vigas, onde são mostradas as referências dos garfos usados em cada viga e as respectivas quantidades;

- quantitativos de painéis de lajes, onde são mostrados todos os recortes de cada laje com suas respectivas dimensões;

- quantitativos de longarinas e escoras por laje, onde são mostradas as dimensões das longarinas e escoras por lajes.

\section{b) Desenhos dos painéis de pilares}

Os painéis de pilares são detalhados nos desenhos em anexo no projeto. Os dados gerais que aparecem no detalhamento são: quantitativos de peças lineares (sarrafos, barrotes, tábuas) utilizadas, distâncias horizontais e alturas dos tensores, recortes nos painéis, rebaixos, desenho esquemático dos painéis em planta e elevados.

A escala usada no detalhamento dos pilares é aleatória, valendo apenas a cota.

\section{c) Desenhos dos painéis de vigas}

Os painéis de vigas são detalhados nos desenhos em anexo no projeto. Os dados gerais que aparecem no detalhamento são: quantitativos de peças lineares 
(sarrafos) utilizadas, recortes nos painéis, desenho esquemático dos painéis em planta e elevados.

A escala usada no detalhamento dos pilares é aleatória, valendo apenas a cota.

\section{d) Desenhos dos garfos}

Nos desenhos dos garfos constam as referências de cada um (exemplo: G1, $\mathrm{G} 2, \ldots)$, com suas dimensões e indicadas a que vigas estes garfos se referem. A escala usada no detalhamento dos pilares é aleatória, valendo apenas a cota.

\section{e) Planta de paginação dos painéis de lajes}

Nesta planta está definida a paginação das lajes, onde cada chapa recebe uma numeração. Tal numeração é usada no plano de corte das chapas, facilitando assim, a montagem do assoalho. E ainda esta numeração será de grande utilidade no que diz respeito à localização dos furos para passagem de tubulação hidráulica e elétrica, uma vez que é necessário manter a paginação das chapas, em todos os pavimentos-tipo.

\section{f) Planta de locação de longarinas e escoras}

Nesta planta são definidos os espaçamentos utilizados para as longarinas, transversinas e para as escoras. Nesta planta constam apenas a numeração das lajes, mantida a do projeto de cálculo estrutural; as longarinas e transversinas, com a contagem de canto a canto da laje; e as escoras, com a contagem do espaçamento entre elas; o que contribui para uma montagem simples e rápida.

\section{g) Planta de montagem dos painéis de vigas}

A nomenclatura utilizada nos desenhos do detalhamento dos painéis de vigas assim como as devidas dimensões são inseridas nesta planta, mostrando exatamente a localização dos painéis de vigas, sendo indicadas a largura e o comprimento. 
Cada dimensão que consta nesta planta é igual à dimensão do desenho dos detalhes dos painéis das vigas.

Tal nomenclatura é mantida em todo projeto a fim de que, já no corte das chapas, haja a separação dos elementos. Os recortes serão conferidos com os desenhos do detalhamento e montados com o auxílio da Planta de Montagem.

\section{h) Planta de locação de garfos e pontaletes}

Os garfos detalhados aparecerão nesta planta, cotados, assim como os pontaletes. Sugere-se marcar no fundo das vigas a localização dos garfos apresentada nesta planta e, feito isto na primeira e segunda lajes, nas outras lajes apenas deverá haver uma conferência no espaçamento destes.

\section{i) Planta de locação de pontaletes e faixas para reescoramento de lajes}

Ao se iniciar a desmoldagem das lajes, é imprescindível que estas permaneçam escoradas. Portanto, faixas são apoiadas por pontaletes e tanto o espaçamento das faixas de reescoramento quanto das escoras (pontaletes) são mostradas nesta planta.

\section{j) Planta de locação de pontaletes para reescoramentos de vigas}

Assim como acontece nas lajes, as vigas precisam ser reescoradas para que as vigas do próximo pavimento possam ser fabricadas. Esta planta de locação de pontaletes para reescoramento de vigas traz o espaçamento destes pontaletes nas respectivas vigas.

\section{k) Plano de corte}

No plano de corte da forma do teto tipo estão inseridos os recortes de pilares, vigas e lajes. O encaixe das peças é feito aleatoriamente, ou seja, sem 
preocupação de separar os recortes dos elementos. As chapas são numeradas e recebem o número de um formato, além de serem cotadas. Este formato é o mesmo para as diversas chapas com dimensões e recortes iguais. Os recortes de painéis de pilares, painéis de vigas e de lajes deverão ser separados após o corte, etiquetados de acordo com o formato que cada recorte recebeu e armazenados.

É entregue uma lista de montagem que ajudará a separar os recortes pertencentes a cada elemento. Nesta listagem consta o formato que cada recorte recebeu e o respectivo elemento a que o formato se refere. Depois da separação dos elementos é só utilizar as plantas auxiliares para fazer a montagem.

O aproveitamento conseguido é mostrado no relatório final, já considerado o desconto da serra, geralmente de $0,5 \mathrm{~cm}$ para cada corte.

\subsection{Definição do preço para o projeto de fôrmas}

\subsubsection{Estudos e projetos}

Independentemente do tipo de estrutura e do material de construção a ser utilizado, define-se o escopo geral a seguir. Os estudos e projetos serão no caso mais geral, realizados em seis etapas:

\section{a) Estudos preliminares}

Nessa etapa serão levantados os dados necessários e estabelecidos os parâmetros para a execução do projeto, de comum acordo com a contratante ou seus prepostos e, se necessário, com outros participantes do trabalho. Esta etapa compreende também o estudo de alternativas e a produção de documentos que possibilitem uma estimativa inicial dos custos da obra.

\section{b) Anteprojeto}

Etapa destinada à concepção e à representação do conjunto de informações técnicas provisórias de detalhamento, necessários ao inter-relacionamento das atividades técnicas de projeto. Os elementos resultantes deverão ser suficientes à 
elaboração de estimativas mais apuradas de custos e de prazos dos serviços de obra implicados.

\section{c) Projeto básico}

O projeto básico deverá atingir um nível de detalhamento suficiente para que fique perfeitamente definida a estrutura quanto à sua forma e dimensão. Caso seja previsto no contrato, esta fase de projeto deverá conter dados suficientes para a licitação e contratação dos serviços de obra correspondentes.

\section{d) Projeto executivo}

O projeto executivo se destina à concepção e à definição final do conjunto de informações técnicas para a realização da obra, incluindo quantitativos de materiais, especificações técnicas e de serviços, e quando previsto no contrato, o memorial de cálculo completo.

\section{e) Projeto de fabricação}

Nos projetos onde existam partes da estrutura produzidas segundo processos industriais, é necessária a produção de um projeto de fabricação que delineie e quantifique as diversas peças estruturais e seus processos de execução.

\section{f) Projeto de montagem}

Nas obras onde as peças não são produzidas "in loco", será necessária a execução de um projeto de montagem que especifique a seqüência e cuidados necessários à montagem da estrutura.

\subsubsection{Modalidades de fixação de preços}

Para fixação dos preços dos serviços de engenharia podem ser usadas três modalidades. A escolha das modalidades a serem utilizadas deve considerar a 
natureza do projeto, complexidade das soluções, áreas ou partes não suficientemente desenvolvidas no projeto básico. A escolha de uma modalidade não implica necessariamente na exclusão de outras, uma vez que em um mesmo orçamento pode haver diversos tipos de serviços que serão remunerados de modo diferente.

A modalidade A, baseada no custo da estrutura, pode ser utilizada em projetos e serviços que tenham o seu escopo bem definido, fixando-se, geralmente, um preço global para o serviço.

A modalidade $B$, estabelecida geralmente por folhas de desenho ou memoriais produzidos, é conveniente para obras cujo volume ou área estrutural convencionais sejam de difícil definição ou cujo detalhamento se apresente de forma pouco previsível ou ainda quando o valor da obra é insignificante em face do projeto necessário.

A modalidade $\mathrm{C}$ é conveniente para consultorias, obras complexas de difícil definição inicial do escopo de trabalho, assim como para serviços de modificações de projetos.

Para as três modalidades são utilizados custos unitários padronizados, que muitas vezes não são conhecidos no mês referência. Sua atualização deverá ser feita através de um índice econômico conhecido.

\subsubsection{Projetos de fôrmas e cimbramentos}

A seguir são definidas as porcentagens (t) a serem aplicadas sobre o custo convencional da fôrma:

- Para edifícios sem simetria:

$t(\%)=17,3-0,60 \ln (B) \geq 10,3 \%$

- Para edifícios com uma simetria:

$t(\%)=14,6-0,50 \ln (B) \geq 8,7 \%$

- Para edifícios com duas simetrias: 
$t(\%)=12,4-0,47 \ln (B) \geq 6,9 \%$

Sendo B a área convencional de fôrmas em $\mathrm{m}^{2}$.

Obtém-se a área convencional de fôrmas (B) diretamente do projeto de forma de concreto ou, na falta deste, multiplicando-se a área de projeção do pavimento por $k$, dado pela TABELA 7.2, a seguir.

TABELA 7.2 - Coeficiente $\mathrm{k}$

\begin{tabular}{c|r}
\hline $\mathbf{k}\left(\mathbf{m}^{2} / \mathbf{m}^{2}\right)$ & Distância de piso a piso (PP) \\
\hline 2,2 & PP $\leq 3,00 \mathrm{~m}$ \\
\hline 2,4 & $3,00 \mathrm{~m}<\quad$ PP $\leq 4,00 \mathrm{~m}$ \\
\hline 2,6 & $4,00 \mathrm{~m}<\quad$ PP $\leq 5,00 \mathrm{~m}$ \\
\hline 3,0 & $5,00 \mathrm{~m}<\quad$ PP \\
\hline
\end{tabular}

\subsubsection{Adicionais específicos para projetos de fôrmas e cimbramentos}

A quantidade de direções pelas faces dos pilares define a quantidade de eixos necessários para montagem das fôrmas. Os adicionais a seguir incidem sobre o custo total, de acordo com a quantidade de pares de eixos, necessários a esta definição. Em seguida, na TABELA 7.3, estão relacionados os adicionais com os pares de eixos.

TABELA 7.3 - Adicional específico de acordo com a quantidade de pares de eixos

\begin{tabular}{c|c}
\hline Par de eixos & Adicional específico (\%) \\
\hline 1 & 0 \\
\hline 2 & 30 \\
\hline 3 & 60 \\
\hline 4 & 90 \\
\hline
\end{tabular}




\subsubsection{Repetições de projetos}

A repetição de um projeto, com a devida autorização de seu autor, será remunerada com base nos percentuais discriminados a seguir, na TABELA 7.4.

TABELA 7.4 - Percentual aplicado ao preço do projeto para repetições

\begin{tabular}{c|c}
\hline Número de repetições (n) & Percentual (\%) \\
\hline 1 a 5 & $25 n$ \\
\hline 6 a 10 & $25+20 n$ \\
\hline 11 a 20 & $75+15 n$ \\
\hline 21 a 40 & $175+10 n$ \\
\hline Mais de 41 & $375+5 n$ \\
\hline
\end{tabular}

Estes valores serão aplicados ao preço do projeto e inclusive correspondem à remuneração dos direitos autorais e à responsabilidade técnica assumida.

\subsection{Considerações finais}

Assim como na elaboração dos projetos de estruturas, hoje pode-se contar com softwares que muito podem "auxiliar" na elaboração do projeto de fôrmas. Entretanto, o engenheiro não pode usar a máquina com seus softwares para substituir a própria criatividade. É importante que se acabe com a impressão errada de que o computador faz tudo, trabalhando de graça e dispensando a participação do engenheiro.

Mais importante que deter-se aos cálculos, não que estes não sejam importantes, é procurar dedicar mais tempo à concepção do projeto, pois nenhum computador alerta para isso.

De nada adianta se o projeto foi bem concebido, se foi bem calculado, porém não bem detalhado, apresentado todos os desenhos necessários para a execução do mesmo, sem gerar dúvidas.

Um projeto de fôrmas bem elaborado pode servir como corretor de um projeto de estruturas, para possíveis falhas, de cota por exemplo, passadas despercebidas em sua fase de detalhamento. Claro que erros que dizem respeitos 
à estabilidade da edificação não deverão, nem serão objeto de responsabilidade do projetista de fôrmas.

Os projetos de "formas" contido no projeto estrutural de uma edificação apresentam, apenas, o formato e as dimensões dos elementos estruturais de concreto, não contendo informações a respeito da fôrma em si. Daí a grande diferença etimológica das palavras "forma", usada para se referir a geometria da estrutura, e "fôrma", usada para se referir à estrutura provisória, cuja função é manter o concreto plástico na geometria desejada e sustentá-lo até que atinja a resistência suficiente para auto-suportar os esforços a que está sujeito.

Um projeto de fôrmas bem elaborado com acompanhamento técnico na execução do projetista pode evitar conseqüências graves com relação à segurança e à estética. $\mathrm{O}$ aspecto da segurança está ligado a erros de dimensionamento, que podem por em risco as equipes que atuam no canteiro de obras. Quanto à estética, encontram-se os problemas que não afetam necessariamente a segurança das estruturas ou das pessoas, entretanto, podem proporcionar aumento nas espessuras de revestimentos, por exemplo, na camada de contrapiso, devido a grandes deformações, desaprumo de peças e defeitos nas superfícies. 


\section{CONCLUSÃO}

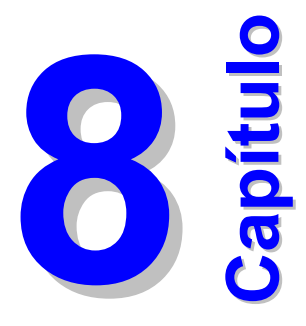

Por fim, esse capítulo apresenta considerações gerais sobre o assunto ora estudado "fôrmas para concreto". Durante todo o trabalho, o que se tentou fazer foi mostrar a posição de status que o tema se encontra. Como todos os setores do mercado, a construção civil tem que ingressar na industrialização e, essa consciência deve atingir toda a pirâmide hierárquica da construção. De nada adianta se derem ao trabalhador a máquina adequada se, entretanto, não lhe for explicado o funcionamento, bem como sua utilização, ela vai ser obrigado a fazer alguma gambiarra.

Durante o trabalho foram apresentadas as características intrínsecas das chapas de madeira compensada, por ser o material mais utilizado como molde nas fôrmas para concreto.

Estudou-se as ações a que estão sujeitos os sistemas de fôrmas, auxiliando os projetistas na definição dos carregamentos.

Dada a complexidade na definição das envoltórias das pressões que o concreto exerce nas faxes laterais das fôrmas, foram efetuados ensaios experimentais. Através destes definiu-se uma proposta de formulação para estimar essas pressões com base na teoria de Mohr-Coulomb. 
Em seguida foram tratados todos os procedimentos de dimensionamento das fôrmas, estes baseados na norma NBR 7190 (1997) - Projeto de Estruturas de Madeira. Com a profunda reformulação da norma NBR 7190 (1982), originariamente NB 11 (1951), baseada no método das tensões admissíveis, para a nova versão da norma brasileira NBR 7190 (1997), fundamentada no método dos estados limites, torna-se necessário esclarecer os pontos relevantes que norteiam esta transição.

É dedicado um capítulo para a apresentação das disposições construtivas que auxiliam tanto na fase projetual, como de execução. O capítulo também esclarece sobre as ações construtivas a que estão submetidas as estruturas dos edifícios de concreto armado (a partir da fase de concretagem), através de um estudo do escoramento e reescoramento das estruturas (Método de Grundy e Kabaila).

De acordo com as análises obtidas anteriormente, foram apresentadas algumas regras gerais de elaboração do projeto e desenhos de fôrmas baseados nas recomendações da NBR 10067 (1995), e também práticas.

Acredita-se que as informações contidas nesta dissertação possam auxiliar nos cursos de graduação em Engenharia Civil, bem como aos profissionais do mercado e na definição de novas pesquisas. 


\section{BIBLIOGRAFIA}

ALEXANDRIS, A.; GARDNER, N. J. (1981). Mechanical behaviour of fresh concrete. Cement and Concrete Research, v. 11, n. 3, p. 323-339, May.

ALMEIDA JR., C. C. (1996). Manual de utilização e montagem de fôrmas para concreto armado em edifícios de andares múltiplos. Goiânia: TOR Engenharia.

ALMEIDA PRADO, J. F. M. (1999). Estruturas de edifícios em concreto armado submetidas a ações de construção. São Carlos. Tese (Doutorado) - Escola de Engenharia de São Carlos, Universidade de São Paulo.

AMERICAN CONCRETE INSTITUTE (1958). ACI 622/58 - Pressures on formwork. Detroit, $\mathrm{ACl}$.

AMERICAN CONCRETE INSTITUTE (1988). ACI 347R/88 - Guide to formwork for concrete. Detroit, ACI.

ASSAHI, P. N. (1990). Qualidade e produtividade na construção civil - Fôrma para estrutura de concreto armado. São Paulo: EPUSP/ITQC.

ASSOCIAÇÃO BRASILEIRA DE CIMENTO PORTLAND (1944). Fôrmas de madeira para concreto armado em edifícios comuns. Boletim Técnico $n^{\circ} 50$. São Paulo. 
ASSOCIAÇÃO BRASILEIRA DE NORMAS TÉCNICAS (1951). NB 11 - Cálculo e execução de estruturas de madeira. Rio de Janeiro: ABNT.

ASSOCIAÇÃO BRASILEIRA DE NORMAS TÉCNICAS (1978). NBR 6118 - Projeto e execução de obras de concreto armado. Rio de Janeiro: ABNT.

ASSOCIAÇÃO BRASILEIRA DE NORMAS TÉCNICAS (1982). NBR 1982 - Cálculo e execução de estruturas de madeira. Rio de Janeiro: ABNT.

ASSOCIAÇÃO BRASILEIRA DE NORMAS TÉCNICAS (1983). NBR 7678 Segurança na execução de obras e serviços de construção. Rio de Janeiro: ABNT.

ASSOCIAÇÃO BRASILEIRA DE NORMAS TÉCNICAS (1985). NBR 9531 - Chapas de madeira compensada - Classificação. Rio de Janeiro: ABNT.

ASSOCIAÇÃO BRASILEIRA DE NORMAS TÉCNICAS (1986). NBR 9532 - Chapas de madeira compensada - Especificação. Rio de Janeiro: ABNT.

ASSOCIAÇÃO BRASILEIRA DE NORMAS TÉCNICAS (1986). NBR 9533 Compensado - Determinação da resistência à flexão estática. Rio de Janeiro: ABNT.

ASSOCIAÇÃO BRASILEIRA DE NORMAS TÉCNICAS (1986). NBR 9534 Compensado - Determinação da resistência da colagem ao esforço de cisalhamento. Rio de Janeiro: ABNT.

ASSOCIAÇÃO BRASILEIRA DE NORMAS TÉCNICAS (1988). NBR 6123 - Forças devidas ao vento em edificações. Rio de Janeiro: ABNT.

ASSOCIAÇÃO BRASILEIRA DE NORMAS TÉCNICAS (1995). NBR 10067 Princípios gerais de representação em desenho técnico. Rio de Janeiro: ABNT. ASSOCIAÇÃO BRASILEIRA DE NORMAS TÉCNICAS (1996). NBR 7480 - Barras e fios de aço destinados a armaduras para concreto armado. Rio de Janeiro: ABNT.

ASSOCIAÇÃO BRASILEIRA DE NORMAS TÉCNICAS (1997). NBR 7190 - Projeto de estruturas de madeira. Rio de Janeiro: ABNT.

BODIG, J.; JAYNE, B. A. (1982). Mechanics of wood and wood composites. Ed. Van Nostrand Reinhold, New York, 711p.

BOIN, A. C. (1993). Fôrmas e Escoramentos. Apostila do Curso sobre fôrmas e escoramentos na engenharia do concreto, ABCP. 89p.

BRITISH STANDARDS INSTITUTION (1995). BS 5975/95 - Code of practice for falsework. London, 84pp. 
CALIL JR., C. et al. (1998). Fôrmas de madeira para concreto armado. São Carlos. 82p. Publicação: Escola de Engenharia de São Carlos, Universidade de São Paulo.

CALAVERA, J. (1991). Cálculo, construcción y patología de forjados de edificación. $4^{a}$ edición. INTEMAC. Madrid.

CALAVERA, J. (1992). Cálculo de flechas en estructuras de hormigón armado. 1a edición. INTEMAC. Madrid.

CÁNOVAS, M. F. (1988). Patologia e terapia do concreto armado. Ed. Pini, São Paulo, 522p.

CAPUTO, H. P. (1987). Mecânica dos Solos e suas Aplicações. LTC Editora S.A. Rio de Janeiro, vol. 2, 6ª edição.

CARNEIRO, A. M. P. (1995). Sistemas de eixos: o ajuste da verticalidade. Téchne, $\mathrm{n}^{\circ} 17$, jul/ago, ano 3, p. 26-27.

CHEN, W. F.; MOSALLAM, K. H. (1991). Concrete Buildings: Analisys for Safe Construction, CRC Press, Boca Raton, Flórida, 186 pp.

COMITE EURO-INTERNATIONAL DU BETON (1976). Manual de technologie coffrage. Bulletin d'Information, n. 115.

CONCRETE BUILDINGS, NEW FORMWORK PERSPECTIVES (1985). Ceco Concrete Construction Co., Kansas City, MO.

CONSTRUÇÃO (2000). Índices e Custos de Construcão. Ed. Pini, São Paulo, Revista, $\mathrm{n}^{\circ} 2703$, ano LII.

CRITIANI, J. E. R. (1995). Fôrmas de madeira para concreto em edifícios de andares múltiplos. São Paulo. Dissertação (Mestrado) - Escola Politécnica da Universidade de São Paulo.

CRUZ, R. M. (1997). Pressão lateral em fôrmas para concreto. Campinas. 142p. Dissertação (Mestrado) - Faculdade de Engenharia Civil, Universidade Estadual de Campinas.

DEUTSCHES INSTITUT FÜR NORMUNG (1980). DIN 18218-Pressure of concrete on vertical formwork (Frischbeton auf lotrechte schalungen). Berlin, 4 pp.

FAJERSZTAJN, H. (1987). Fôrmas para concreto armado. Aplicação para o caso do edifício. São Paulo. Tese (Doutorado) - Escola Politécnica da Universidade de São Paulo.

FÔRMAS PARA ESTRUTURAS DE CONCRETO (1986). Anais do II Simpósio Nacional de Tecnologia da Construção - Escola Politécnica da Universidade de São Paulo. 
FORMWORK - A guide to good practice (1995). Working Party of the Society's Construction Group, 2nd Edition.

FUSCO, P. B. (1977). Fundamentos estatísticos da segurança das estruturas. EDUSP/McGraw-Hill, São Paulo.

GARDNER N. J. (1979). Control of construction loads on multifloor buildings. Reprint from Canadian Journal of Civil Engineers. Vol. 6, núm. 2.

GARDNER N. J. (1981). Pressure of concrete against formwork. ACI - JOURNAL, Proceedings, v. 77, p. 279-286, july-aug.

GARDNER, N. J. (1985). Pressure of concrete on formwork-A Review. ACl JOURNAL, Proceedings, v. 82-69, p. 744-753, sept-oct.

GRUNDY, P.; KABAILA, A. (1963). Construction loads on slabs with shored formwork in multistory buildings. ACl Structural Journal, v. 60, $\mathrm{n}^{\circ} 12$, dec, p. 1729-1738.

HADIPRIONO, F. C.; WANG, H. K. (1986). Analisys of causes of falsework failures in concrete structures, Journal of Construction Engineering and Management, ASCE, vol. 12, no. 1, 112-121.

HARRINSON, T. A.; CLEAR, C. (1985). Concrete pressure on formwork, Construction Industry Research and Information Association, Report 108, London, September, $32 \mathrm{pp}$.

HURD, M. K. (1995). Formwork for concrete. 6 ${ }^{\mathbf{a}}$ Ed. American Concrete Institute, Special Publication SP4.

LEVY, S.; HELENE, P. R. L. (1996). Cura: como, quando e porquê. Téchne, n²0, jan/fev, ano 4, p. 18-21.

MARANHÃO, G. M.; LAHR, F. A. R. (1999). Pressões Laterais em Fôrmas para Pilares de Concreto Armado. In: $41^{\circ}$ Congresso Brasileiro do Concreto (IBRACON). Salvador, BA.

MASCARENHAS, A. C. Q. (1993). Fôrmas para concreto. Publicação: Escola Politécnica da Universidade Federal da Bahia - UFBA.

MOLITERNO, A. (1989). Escoramentos, cimbramentos, fôrmas para concreto e travessias em estruturas de madeira. Ed. Edgard Blücher, São Paulo.

MONTOYA, P. J. (1987). Hormigon Armado. Tomo 1, $6^{a}$ edição, Ed. Gustavo Gili S.A., Barcelona.

OLIVEIRA, J. T. S.; FREITAS, A. R. (1995). Painéis à base de madeira. Boletim Técnico do Departamento de Engenharia da Construção Civil - Escola 
Politécnica - Universidade de São Paulo. BT/PCC/149, EPUSP, São Paulo. $44 p$.

PAULSON JR., B. C. (1995). Computer applications in construction. McGraw-Hill.

PEURIFOY, R. L.; OBERLENDER, G. D. (1995). Formwork for concrete structures. $3^{\text {rd }}$ Edition. McGraw-Hill.

PFEIL, W. (1987). Cimbramentos. Livros Técnicos e Científicos Editora S.A., Rio de Janeiro.

RAVENET, J. (1992). Silos. Barcelona. pp 7-9.

REQUENA, J. A. V. (1983). Fôrmas e cimbramentos de madeira para edificações. São Carlos. Dissertação (Mestrado) - Escola de Engenharia de São Carlos, Universidade de São Paulo.

RICOUARD, M. J. (1980). Encofrados: cálculo y aplicaciones en edificación y obras civiles, Barcelona, Editores Técnicos Associados S.A.

RITCHIE, A. G. B. (1962). The Triaxial Testing of Fresh Concrete. Magazine of Concrete Research, v. 14, n 40.

RODRIGUES JR., S. J. (1996). Ações de construção em lajes de concreto armado. 158 p. Dissertação (Mestrado) - Departamento de Engenharia Civil, Pontifícia Universidade Católica do Rio de Janeiro, PUC-Rio, Rio de Janeiro.

SBAROUNIS, J. A. (1984). Multistory flat plate buildings - construction loads and immediate deflections. Concrete International, v. 6, $\mathrm{n}^{\circ}$ 2, feb, p. 70-77.

SHEHATA, L. C. D. et al. (1993). Classificação e propriedades do concreto e do aço. UFRJ/COPPE, Rio de Janeiro.

SOUZA, R.; MEKBEKIAN, G. (1996). Qualidade na aquisição de Materiais e execução de obras. São Paulo: Editora Pini.

STAMATO, G. C. (1998). Resistência ao embutimento da madeira compensada. São Carlos. Dissertação (Mestrado) - Escola de Engenharia de São Carlos, Universidade de São Paulo.

VAZ, J. (1987). Silos verticais de madeira compensada. São Carlos. Dissertação (Mestrado) - Escola de Engenharia de São Carlos, Universidade de São Paulo. 


\section{ANEXO}

\section{A.1 Fundamentos teóricos para construção de ábacos para o dimensionamento de chapas de madeira compensada}

Em seguida serão apresentados diretrizes para a elaboração de ábacos no dimensionamento de chapas de madeira compensada.

$\mathrm{Na}$ situação mais desfavorável de apoio, a chapa de madeira compensada pode ser considerada, no trabalho à solicitação por flexão, à semelhança de uma viga sobre um determinado número de apoios, isto é, viga com determinada seção transversal, caracterizada pela largura e altura e com um comprimento, cuja vinculação determina a situação estática, isostática ou hiperestática. A FIGURA A.1 ilustra, de maneira generalizada, a condição estática das chapas de madeira compensada. 


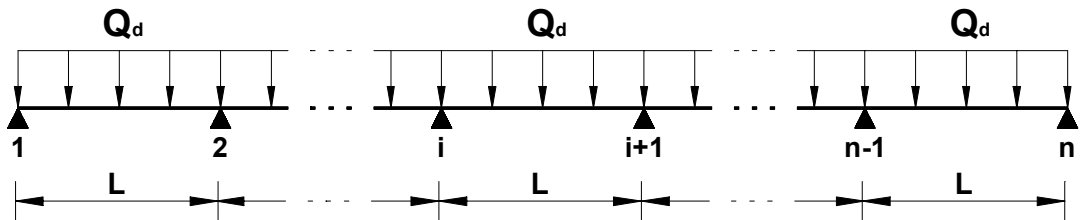

FIGURA A.1 - Esquema estático para as chapas de madeira compensada.

Os ábacos são apresentados com a carga de cálculo $\left(Q_{d}\right)$ no eixo das abcissas e a flecha (f) no eixo das ordenadas. Para cada condição estática, de acordo com as propriedades mecânicas e físicas das chapas, define-se um ábaco. Obtém-se as retas de acordo com os vários espaçamentos $\left(L_{1}, L_{2}, L_{3}, \ldots, L_{n}\right)$ requeridos. As curvas de flecha, momento e cortante são definidas, respectivamente, pela flecha limite máxima, resistência à compressão (ou tração) e resistência ao cisalhamento das chapas. Na FIGURA A.2, em seguida, apresentase o modelo dos ábacos a serem elaborados.

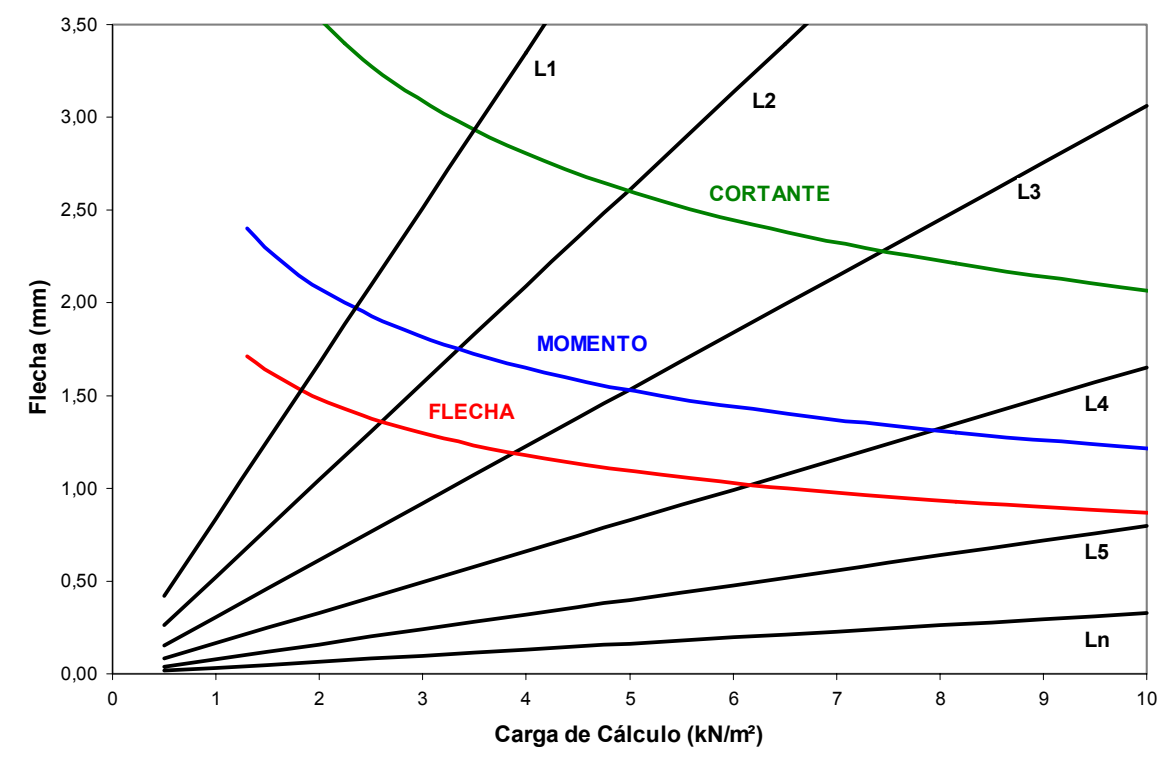

FIGURA A.2 - Modelo do ábaco para dimensionamento das chapas de madeira compensada.

Em seguida são definidas as funções das retas e curvas do ábaco. Para as retas tem-se: 
$f=\frac{K_{f} \cdot L^{4}}{E_{c 0, e f} \cdot l} Q_{k}$

Onde:

$\mathrm{K}_{\mathrm{f}}$ é o coeficiente para o cálculo da flecha máxima, função do modelo estático (ver TABELA 5.10);

$L \quad$ é o espaçamento entre os apoios $\left(L_{1}, L_{2}, L_{3}, \ldots, L_{n}\right)$;

$E_{c 0, e f}$ é o módulo de elasticidade, tomado com o valor efetivo;

I é o momento de inércia da chapa com a faixa unitária;

$Q_{k} \quad$ é a ação total característica (permanentes e variáveis) que está agindo sobre as chapas.

Para a curva limite da flecha define-se a seguinte expressão:

$f_{\text {máx }}=\frac{K_{f} \cdot L^{4}}{E_{c 0, e f} \cdot l} Q_{k}$

Onde $f_{\text {máx }}$ é a flecha limite máxima a ser atingida pela chapa de madeira compensada, sendo igual a L/350 para os casos comuns (EQUAÇÃO 5.6).

A curva limite do momento fletor é definida pelas expressões das EQUAÇÕES A.3 e A.4, dada em seguida.

$$
\begin{aligned}
& Q_{d}=\frac{f_{c 0, d} \cdot l}{K_{M} \cdot y \cdot L^{2}} \\
& f=\frac{K_{f} \cdot L^{4}}{E_{c 0, e f} \cdot l} Q_{d}
\end{aligned}
$$

Onde:

$\mathrm{f}_{\mathrm{c} 0, \mathrm{~d}} \quad$ é a resistência de cálculo à compressão da chapa de madeira compensada;

$\mathrm{K}_{\mathrm{M}}$ é o coeficiente para o cálculo do momento fletor máximo, função do modelo estático (ver TABELA 5.10);

y a maior distância entre a linha neutra na seção transversal considerada, para o caso das chapas é igual a metade da espessura.

Por fim define-se a curva limitada pelo esforço cortante, dada pelas expressões das EQUAÇÕES A.5 e A.6, em seguida. 
$Q_{d}=\frac{2}{3} \frac{f_{v, d} \cdot b \cdot h}{K_{v} \cdot L}$

$f=\frac{K_{f} \cdot L^{4}}{E_{c 0, e f} \cdot l} Q_{d}$

Onde:

$\mathrm{f}_{\mathrm{v}, \mathrm{d}}$ é a resistência de cálculo ao cisalhamento da chapa de madeira compensada;

$\mathrm{K}_{\mathrm{M}}$ é o coeficiente para o cálculo do esforço cortante máximo, função do modelo estático (ver TABELA 5.10);

b largura da seção transversal, sendo unitária;

h altura da seção transversal, igual a espessura da chapa.

Para a construção dos ábacos torna-se necessário, pois, alguns definições, dadas em seguida:

- Espaçamentos entre os apoios $\left(L_{1}, L_{2}, L_{3}, \ldots, L_{n}\right)$;

- Espessura da chapa de madeira compensada (e);

- Intervalo de cargas no eixo das abcissas;

- Flecha limite máxima;

- Resistência à compressão da chapa na direção considerada;

- Resistência ao cisalhamento da chapa;

- Módulo de elasticidade da chapa na direção considerada;

- Coeficientes de modificação ( $k_{\bmod 1}, k_{\bmod 2}$ e $\left.k_{\bmod 3}\right)$;

- Coeficiente de minoração na flexão $\left(\gamma_{m}\right)$;

- Coeficiente de minoração no cisalhamento $\left(\gamma_{m}\right)$;

- Coeficiente de majoração das ações $\left(\gamma_{\mathrm{f}}\right)$;

- Coeficientes de vinculação, de acordo com o modelo estático $\left(\mathrm{K}_{\mathrm{f}}, \mathrm{K}_{\mathrm{M}}\right.$ e $\left.\mathrm{K}_{\mathrm{V}}\right)$.

Com intuito de exemplificar, em seguida é apresentado um ábaco com uma situação estática de dois vãos (FIGURA A.3). Percebe-se que as curvas limites do momento fletor e do esforço cortante não aparecem no ábaco, isso porque para a magnitude das cargas consideradas estas não foram limitantes, apenas a curva limite da flecha, como na maioria dos casos correntes. Para a construção deste ábaco foram definidos:

- Espaçamentos: $\mathrm{L}_{1}=100 \mathrm{~cm}, \mathrm{~L}_{2}=90 \mathrm{~cm}, \mathrm{~L}_{3}=80 \mathrm{~cm}, \mathrm{~L}_{4}=70 \mathrm{~cm}, \mathrm{~L}_{5}=60 \mathrm{~cm}, \mathrm{~L}_{6}$ $=50 \mathrm{~cm}, \mathrm{~L}_{7}=40 \mathrm{~cm}$ e $\mathrm{L}_{8}=30 \mathrm{~cm}$; 
- Espessura da chapa de madeira compensada: e = $18 \mathrm{~mm}$;

- Intervalo de cargas (de cálculo) no eixo das abcissas: $0 \leq Q_{d} \leq 10 \mathrm{kN} / \mathrm{m}^{2}$;

- Flecha limite máxima: L/350;

- Resistência à compressão da chapa (direção paralela): $f_{c 0, k}=50000 \mathrm{kN} / \mathrm{m}^{2}$;

- Resistência ao cisalhamento da chapa: $\mathrm{f}_{\mathrm{v}, \mathrm{k}}=700 \mathrm{kN} / \mathrm{m}^{2}$;

- Módulo de elasticidade médio da chapa (direção paralela): $\mathrm{E}_{\mathrm{c} 0, \mathrm{~m}}=6000 \mathrm{kN} / \mathrm{m}^{2}$;

- Coeficientes de modificação: $k_{\bmod 1}=1,0, k_{\bmod 2}=1,0$ e $k_{\bmod 3}=1,0$;

- Coeficiente de minoração na flexão: $\gamma_{m}=1,4$;

- Coeficiente de minoração no cisalhamento: $\gamma_{m}=1,8$;

- Coeficiente de majoração das ações: $\gamma_{f}=1,4$;

- Coeficientes de vinculação, de acordo com o modelo estático: $K_{f}=1 / 192, K_{M}=$ $1 / 8$ e $K_{V}=5 / 8$.

Considerando uma chapa com $122 \mathrm{~cm}$ a ser apoiada, com um carregamento $Q_{d}=6,3 \mathrm{kN} / \mathrm{m}^{2}$, percebe-se através do ábaco que a chapa suporta bem com a situação estática de dois vãos $(L=61 \mathrm{~cm})$, apresentando uma flecha de $1,11 \mathrm{~mm}$. Podendo ter um espaçamento de até $71 \mathrm{~cm}$, com flecha de 2,02 mm.

\section{A.2 Algoritmos para o dimensionamento dos subsistemas de fôrmas}

São apresentados também nas páginas seguintes algoritmos para o dimensionamento dos subsistemas de lajes, vigas e pilares.

O intuito é de facilitar uma possível automatização do cálculo das fôrmas, estes algoritmos podem, também, serem úteis nas rotinas de cálculo dos escritórios de projeto de fôrmas. 







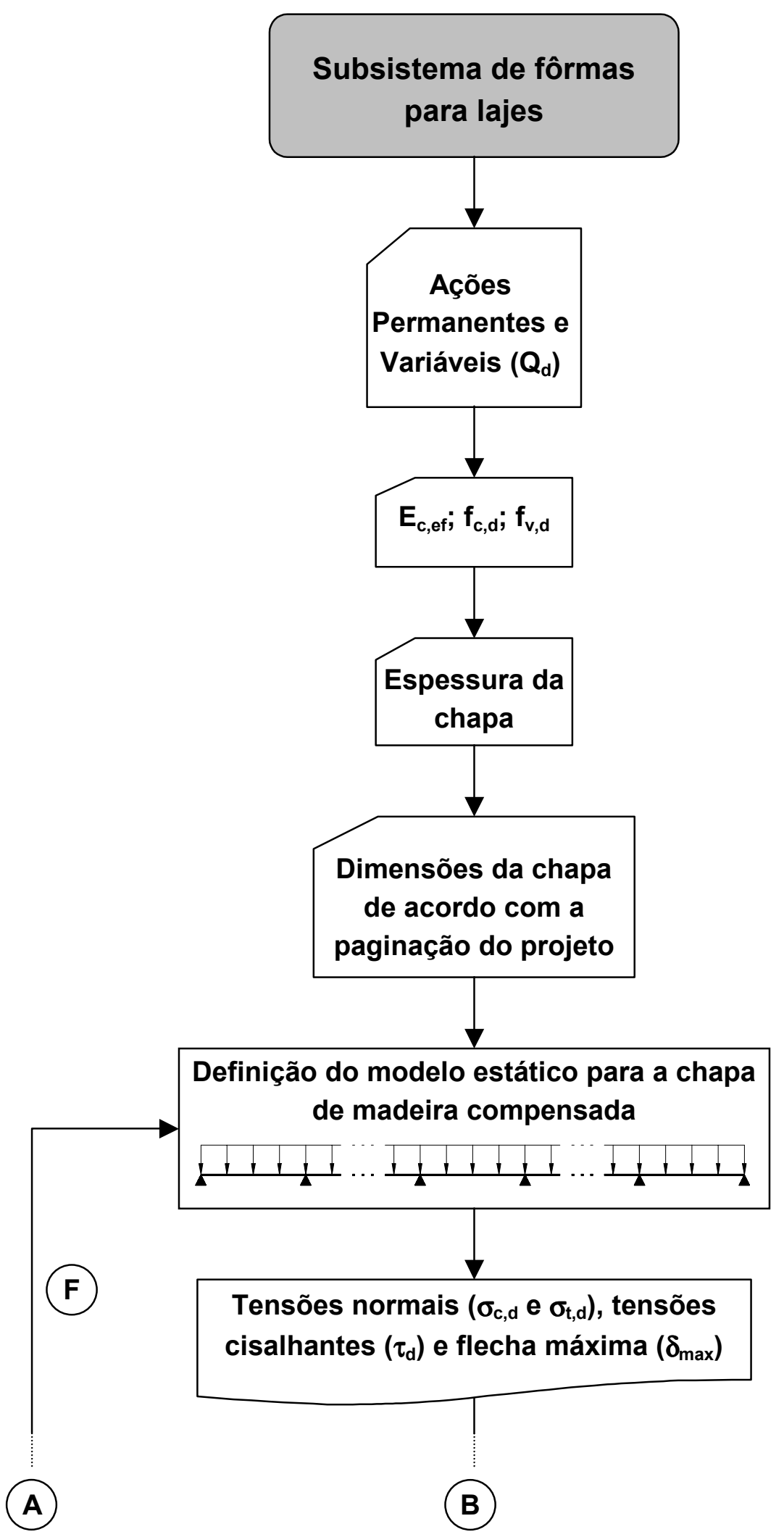


(A)

(B)




(A)

(B)

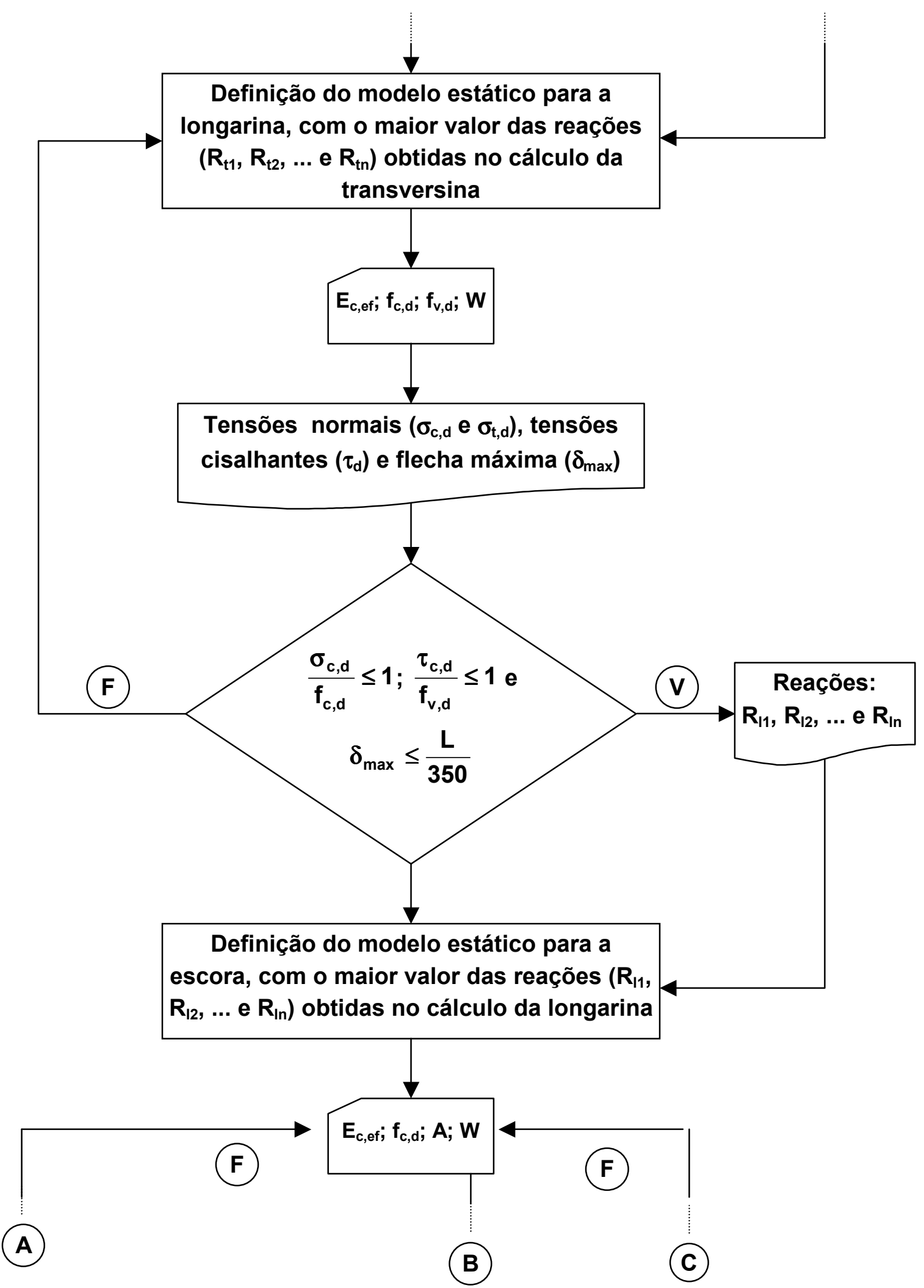


(A)

(B)

(C)

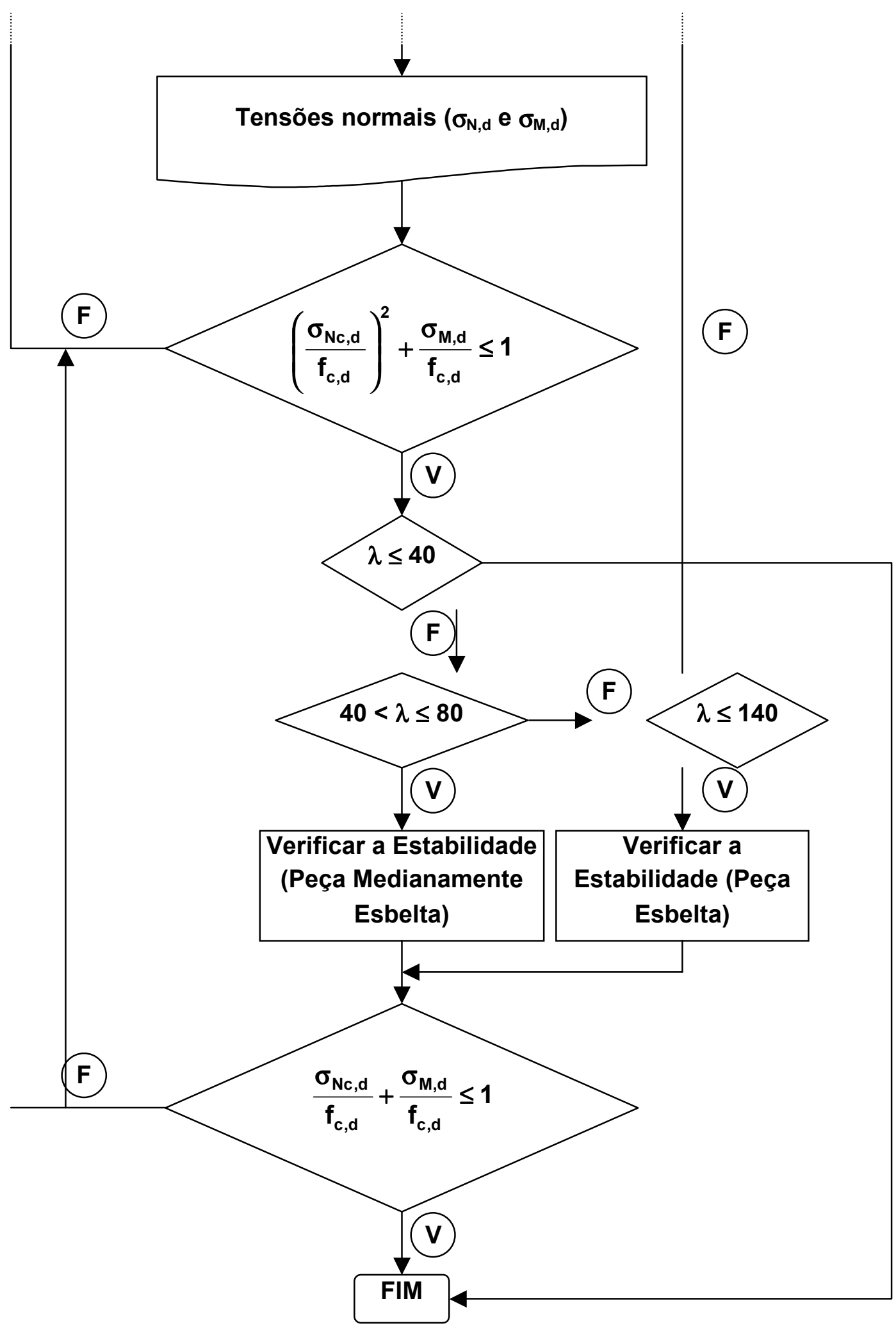




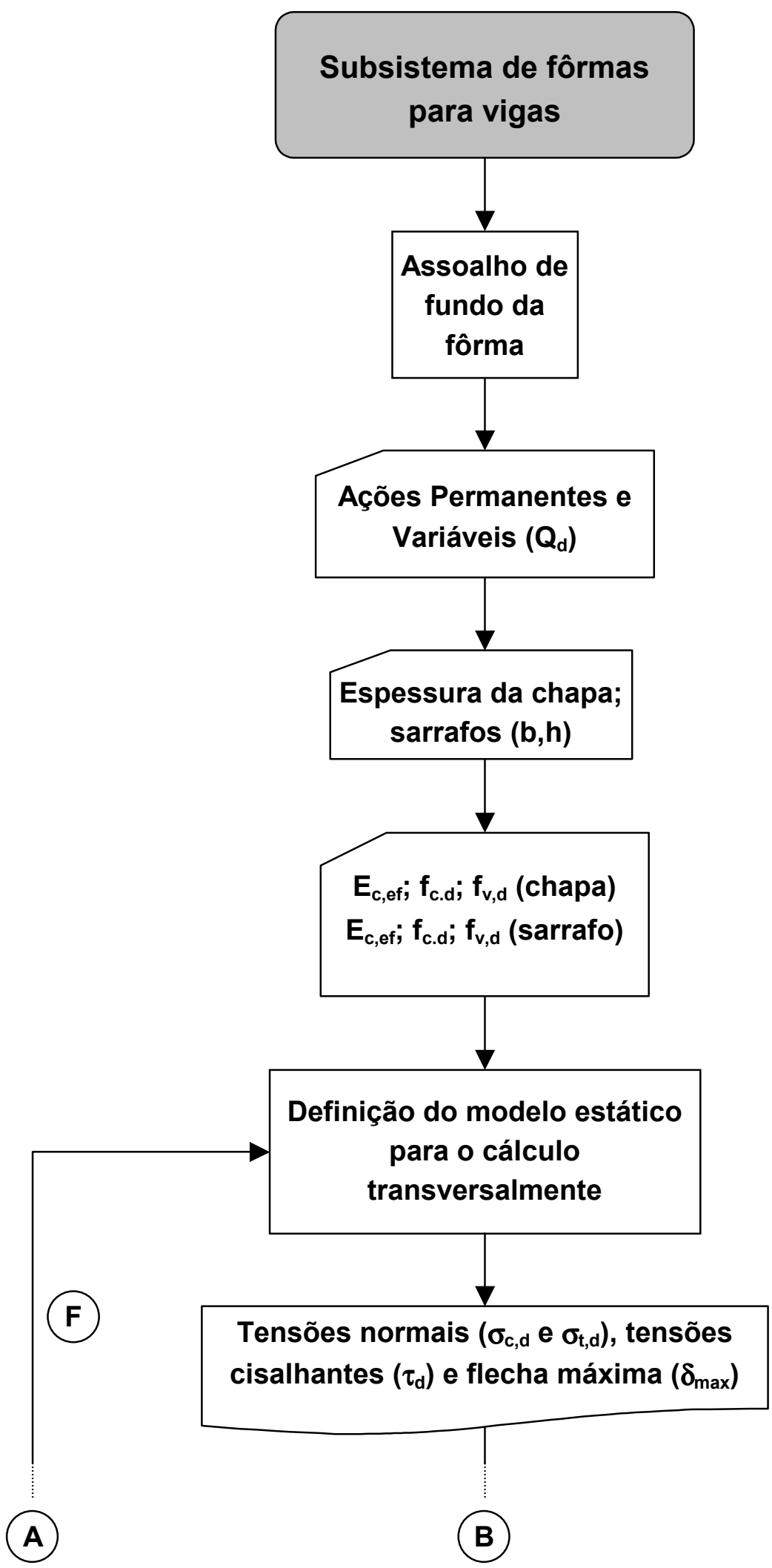


(A)

(B)

F

$\frac{\sigma_{c, d}}{f_{c, d}} \leq 1 ; \frac{\tau_{c, d}}{f_{v, d}} \leq 1 \mathrm{e}$

$\delta_{\max } \leq \frac{L}{350}$

(v)

Definição do modelo estático

para o cálculo

longitudinalmente

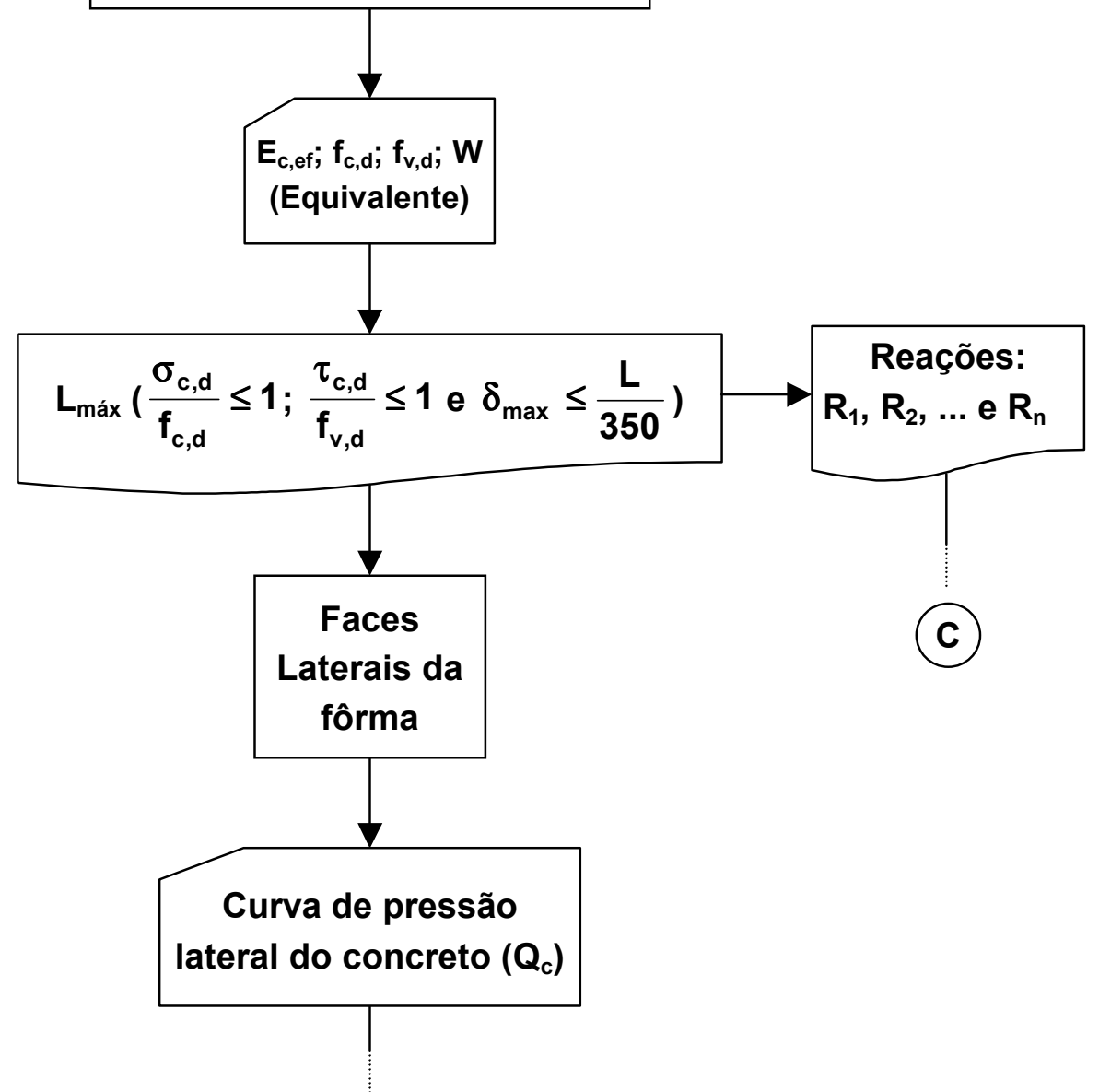

(A) 
(A)

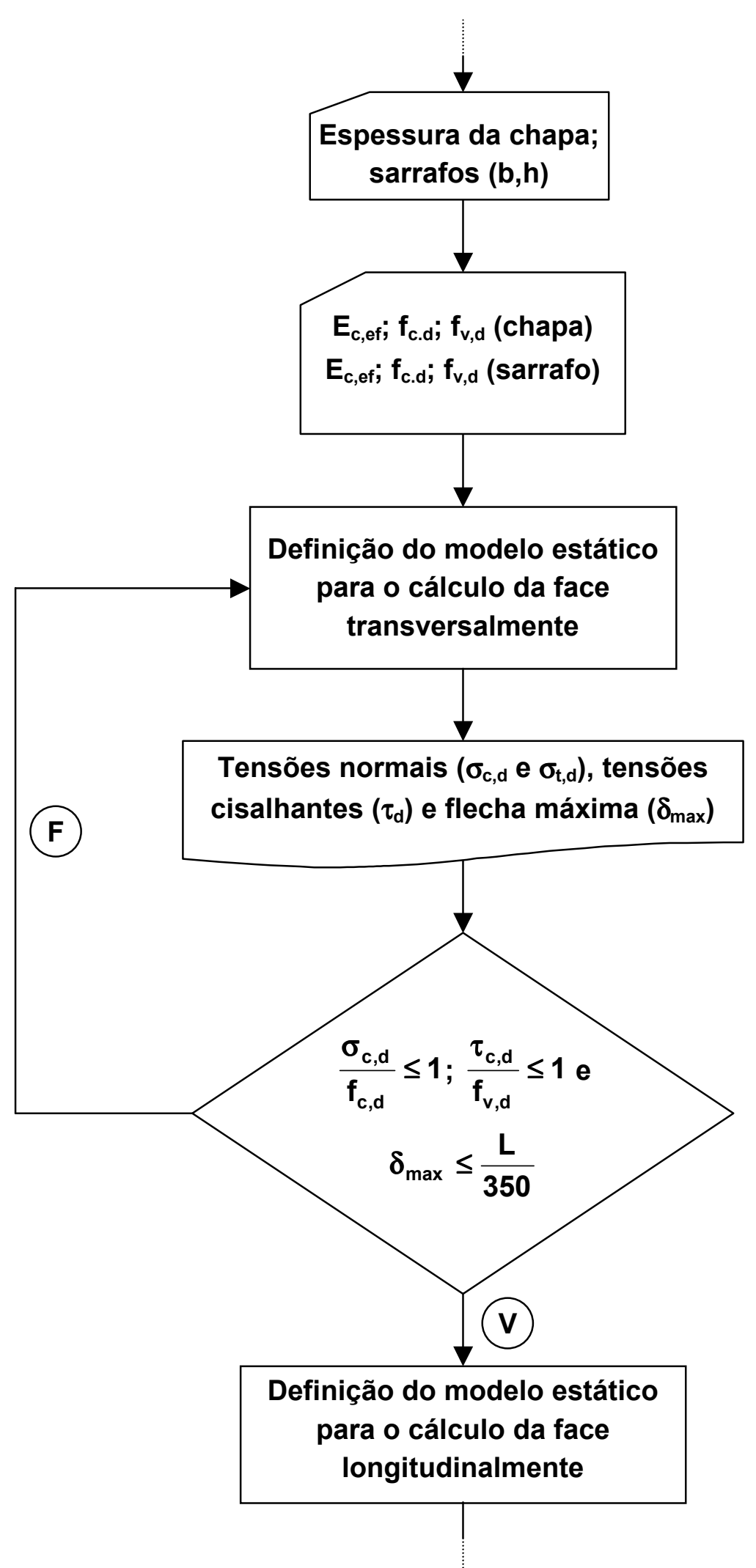




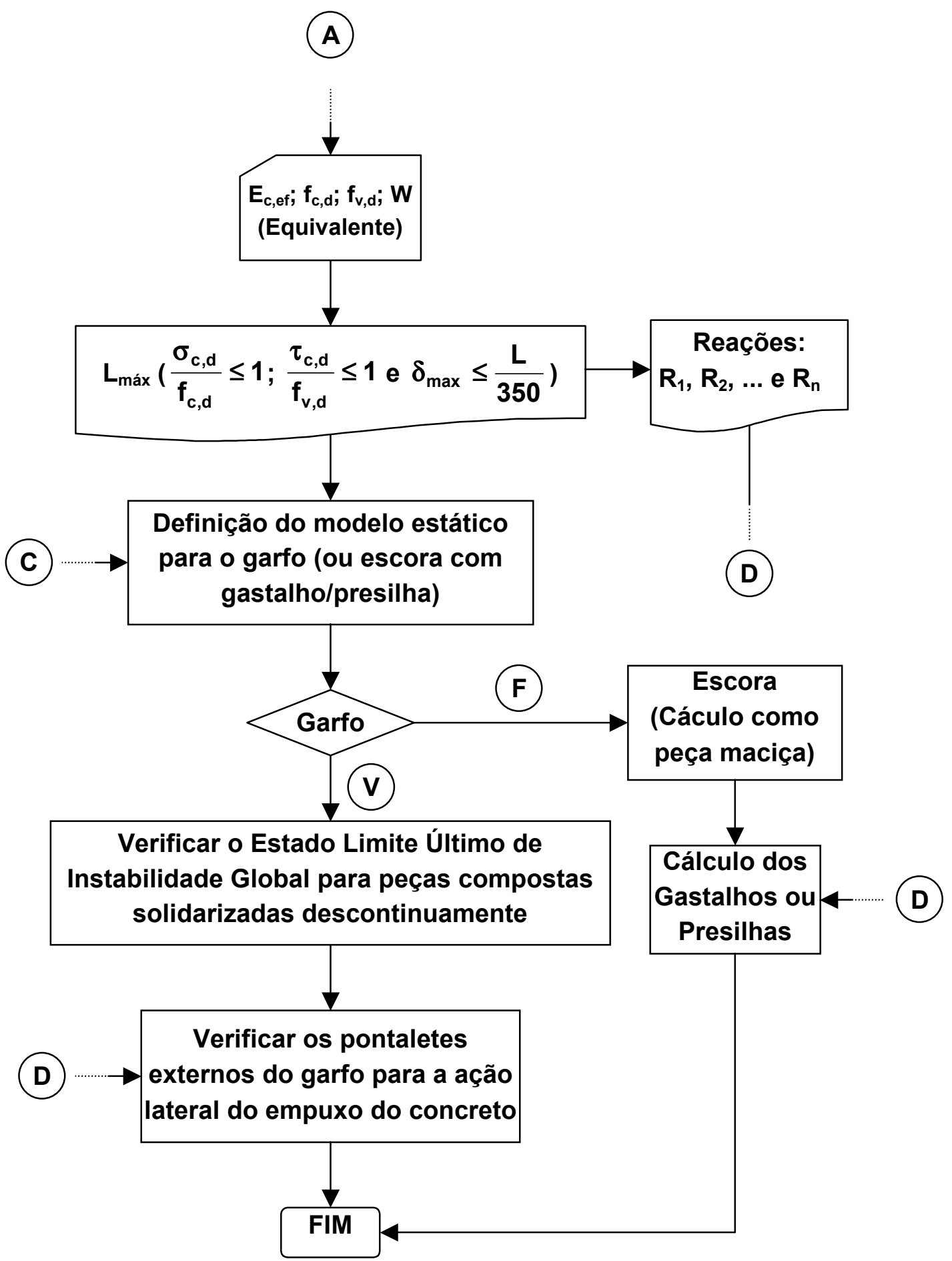




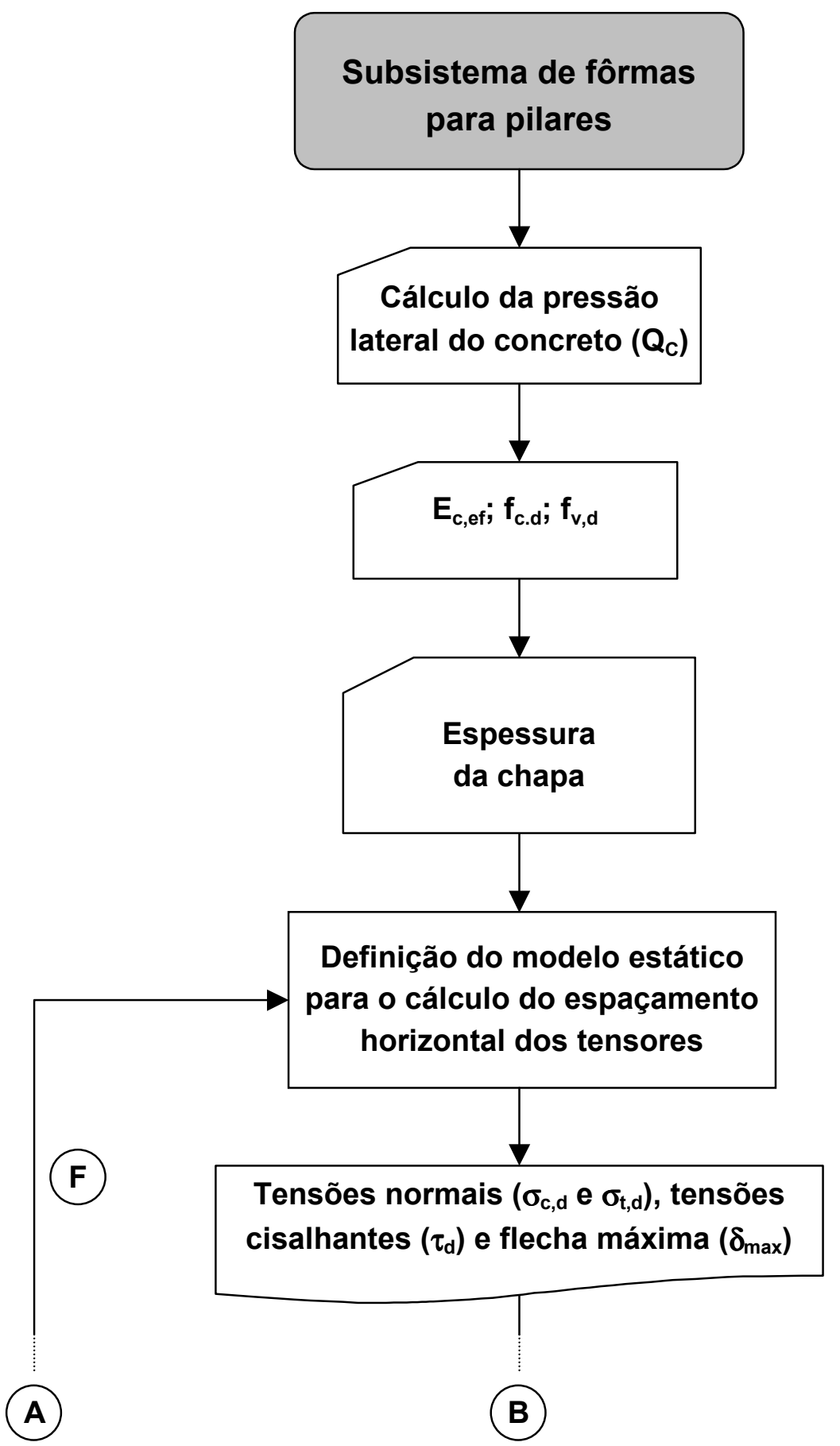


(A)

(B)



(F) $\frac{\sigma_{c, d}}{f_{c, d}} \leq 1 ; \frac{\tau_{c, d}}{f_{v, d}} \leq 1 \mathrm{e}$ (V) Reações: $R_{\mathrm{g} 1}, \mathbf{R}_{\mathrm{g} 2}, \ldots$ e $\mathbf{R}_{\mathrm{gn}}$






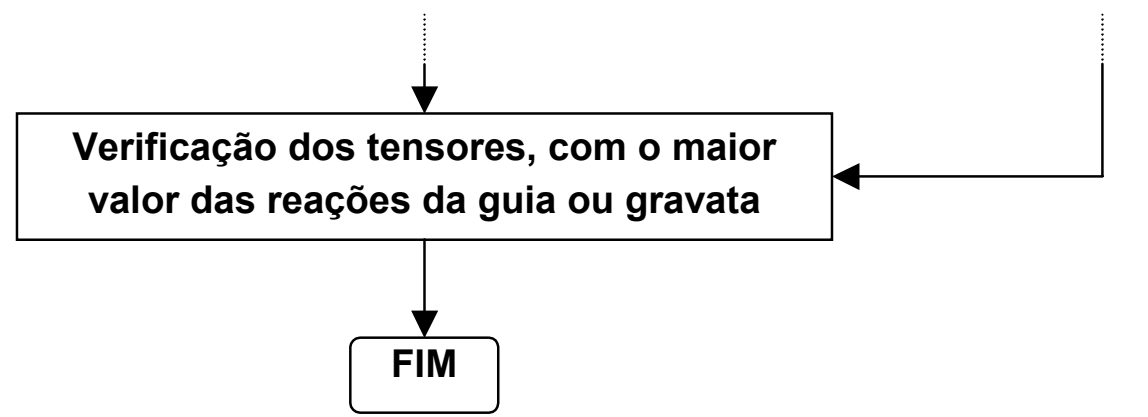

